\author{
UNIVERSIDADE DE SÃO PAULO \\ ESCOLA DE COMUNICAÇÕES E ARTES
}

LUIZ CARLOS GONÇALVES DE OLIVEIRA JÚNIOR

$\mathrm{O}$ cinema de fluxo e a mise en scène 
LUIZ CARLOS GONÇALVES DE OLIVEIRA JÚNIOR

\section{O cinema de fluxo e a mise en scène}

Dissertação apresentada à Escola de Comunicações e Artes da Universidade de São Paulo, para obtenção do Título de Mestre em Meios e Processos Audiovisuais.

Área de Concentração: Meios e Processos Audiovisuais

Orientador: Prof. Dr. Ismail Norberto Xavier 
Autorizo a reprodução e divulgação total ou parcial deste trabalho, por qualquer meio convencional ou eletrônico, para fins de estudo e pesquisa, desde que citada a fonte.

Oliveira Jr., Luiz Carlos Gonçalves de

O cinema de fluxo e a mise en scène / Luiz Carlos Gonçalves de Oliveira Júnior. -- São Paulo : L. C. G. Oliveira Jr., 2010.

$161 \mathrm{p}$.

Dissertação (Mestrado) - Departamento de Cinema, Rádio e Televisão / Escola de Comunicações e Artes/USP.

Orientador: Prof. Dr. Ismail Norberto Xavier.

Bibliografia

1. Estética cinematográfica - mise en scène 2. Cinema de fluxoClaire Denis - Hou Hsiao-hsien 3. Crítica cinematográfica Cahiers du Cinéma - Michel Mourlet 4. Maneirismo 5. Cinemadispositivo - Gus Van Sant I. Xavier, Ismail Norberto II. Título.

CDD 21.ed. -791.43 
FOLHA DE APROVAÇÃO

Luiz Carlos Gonçalves de Oliveira Júnior

O cinema de fluxo e a mise en scène

Dissertação apresentada ao Programa de PósGraduação em Meios e Processos Audiovisuais, para obtenção do Título de Mestre.

Área de Concentração: Meios e Processos

Audiovisuais.

Linha de Pesquisa: História, Teoria e Crítica.

Orientador: Prof. Dr. Ismail Norberto Xavier.

Aprovado em:

Banca examinadora:

Prof. Dr.

Instituição:

Assinatura:

Prof. Dr.

Instituição:

Assinatura:

Prof. Dr.

Instituição:

Assinatura: 


\section{Agradecimentos:}

Ao Prof. Dr. Ismail Xavier, pela orientação atenciosa, lúcida, pela generosidade em partilhar sua sabedoria, pela capacidade de ir exatamente no ponto problemático de um texto e torná-lo melhor.

À Fundação de Amparo à Pesquisa do Estado de São Paulo, pela bolsa de mestrado concedida e pelo apoio financeiro para a realização desta pesquisa.

Ao Conselho Nacional de Desenvolvimento Científico e Tecnológico - CNPq, pela bolsa de mestrado concedida e pelo apoio financeiro para a realização desta pesquisa.

Ao Prof. Dr. Rubens Machado Jr. e à Profa. Dra. Stella Senra, pela bela leitura que fizeram da parte I da dissertação e pelas sábias observações e sugestões durante a qualificação, que ajudaram a aprimorar este trabalho. 


\title{
RESUMO
}

OLIVEIRA Jr., L. C. G. O cinema de fluxo e a mise en scène. 2010. 161 p. Dissertação (Mestrado) - Escola de Comunicações e Artes, Universidade de São Paulo, São Paulo, 2010.

A dissertação é dividida em duas partes. A primeira consiste em um estudo sobre a noção de mise en scène no cinema, levando em conta suas origens teatrais e algumas de suas aplicações na teoria cinematográfica. $\mathrm{O}$ enfoque privilegia as definições essencialistas formuladas por uma parcela da crítica francesa, concentrada nas revistas Cahiers du Cinéma e Présence du Cinéma nos anos 1950-60. A segunda parte da dissertação, mais fincada na análise fílmica, aborda alguns elementos estéticos do cinema contemporâneo, dentre eles o conceito de cinema de fluxo, que designa um conjunto de filmes que ocupam um ponto cego em relação à definição clássica de mise en scène trabalhada na parte I. O Intruso (Claire Denis, 2004), Sombra (Philippe Grandrieux), A Viagem do Balão Vermelho (Hou Hsiao-hsien, 2007) e Gerry (Gus Van Sant, 2002) são alguns dos filmes analisados.

Palavras-chave: Mise en scène. Estética de fluxo. Crítica cinematográfica.

\begin{abstract}
OLIVEIRA Jr., L. C. G. Cinema of flux and mise-en-scène. 2010. 161 p. Dissertation (Masters) - Escola de Comunicações e Artes, Universidade de São Paulo, São Paulo, 2010.

My dissertation is divided in two parts. The first one investigates the concept of mise-enscène as applied to film practice, taking as reference its theatrical origins and some of its extensions to film theory and criticism. My approach privileges the essentialist definitions presented by a group of French critics, focusing on two reviews, Cahiers du Cinéma and Présence du Cinéma, covering their issues published in the 1950's and 1960's. The second part, concentrated on film analysis, discusses some aesthetic features of contemporary cinema such as the notion of "cinema of flux", which refers to a set of films located at a "blind spot" when we look at cinema styles from the standpoint of the classical definition of mise-en-scène discussed in Part I. The intruder (Claire Denis, 2004), Shade (Philippe Grandrieux, 1998), The voyage of the red balloon (Hou Hsiao-hsien, 2007) and Gerry (Gus Van Sant, 2002) are among the films.
\end{abstract}

Key words: Mise-en-scène. Aesthetics of flux. Film criticism. 


\section{SUMÁRIO}

Introdução

\section{Tudo está na mise en scène}

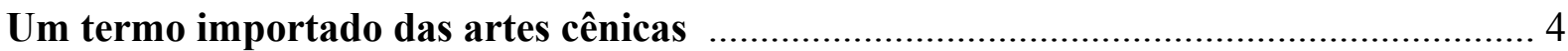

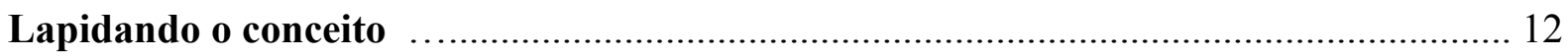

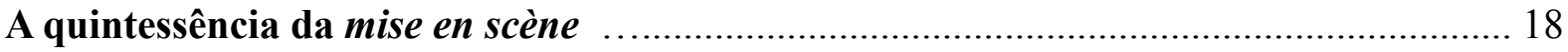

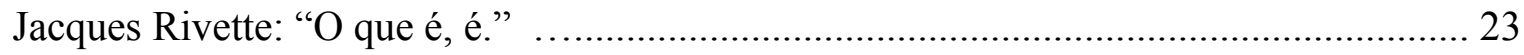

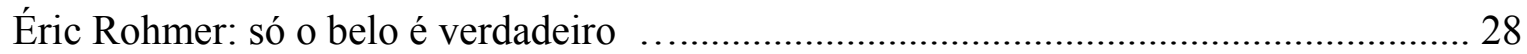

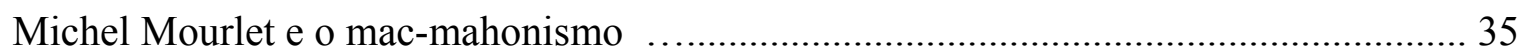

Do sublime e da abjeção .......................................................................................... 58

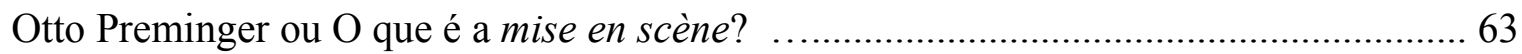

\section{Onde está a mise en scène?}

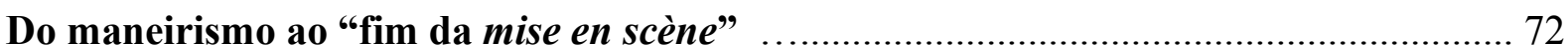

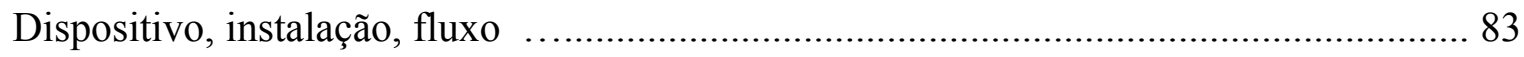

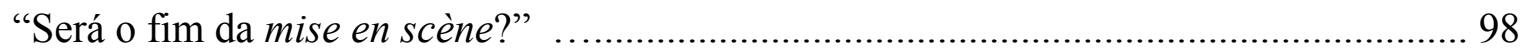

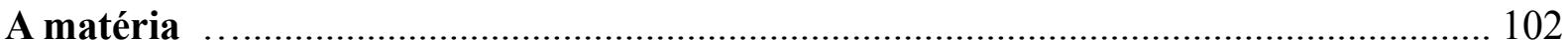

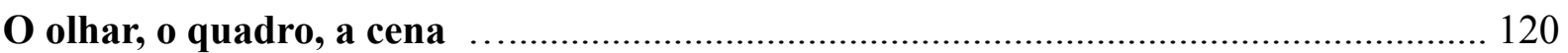

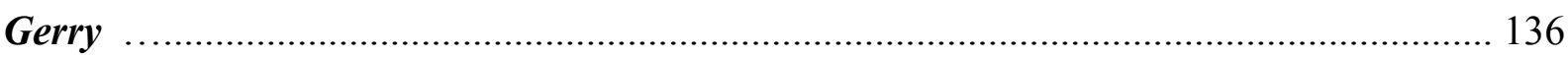

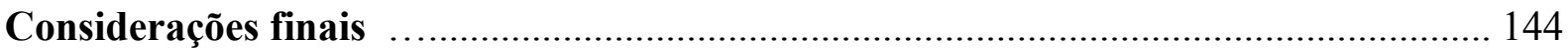

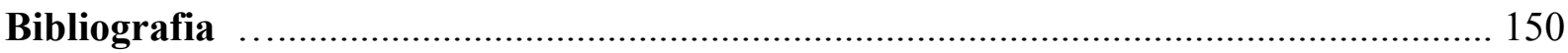

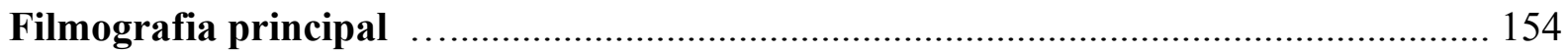




\section{Introdução}

“Tudo está na mise en scène". Quando o crítico francês Michel Mourlet escreve isso em seu polêmico manifesto estético "Sur un art ignoré", publicado nos Cahiers du Cinéma em 1959, ele quer dizer que o principal do cinema, sua essência, está na forma como o filme nos transporta através daquele universo a um só tempo próximo e desconhecido que a tela oferece. A mise en scène é nosso passaporte para o mundo do filme, nosso meio de fascinação perante a arte da escrita luminosa do movimento. Mas é também, como Jacques Rivette não deixará de salientar, um pensamento-em-ação, a encarnação de uma idéia, um movimento discursivo do pensamento e da percepção.

Quatro décadas depois, na passagem dos anos 1990-2000, observam-se filmes que parecem na extremidade oposta da mise en scène teorizada e enaltecida nos Cahiers dos anos 1950: filmes que se apresentam como "um fluxo esticado, contínuo, um escorrer de imagens no qual se abismam todos os instrumentos clássicos mantidos pela própria definição da mise en scène". Para falar desses filmes, Stéphane Bouquet cria o conceito de "estética de fluxo", que aqui utilizaremos também como cinema de fluxo. Jean-Marc Lalanne, um ano depois, retoma o conceito e o amplia. Basicamente, a designação é produto de uma tentativa de compreender o mínimo denominador comum dos filmes que esteticamente mais intrigam os críticos dos Cahiers du Cinéma no início dos anos 2000. Nos realizadores contemplados pelo conceito (dentre eles, Hou Hsiao-hsien, Claire Denis, Gus Van Sant, Apichatpong Weerasethakul e Philippe Grandieux), o que há em comum não é um estilo ou um "traço", mas um comportamento do olhar que desafia as noções tradicionais de mise en scène. Segundo Stéphane Bouquet, um número cada vez maior de cineastas contemporâneos estaria inserindo seus filmes dentro desse paradigma do fluxo. Após o esgotamento do maneirismo, que por sua vez já era o esgotamento do moderno, surge um cinema que não irá se apresentar como um neo-classicismo. Muito pelo contrário: ele impossibilitará que se fale de mise en scène como se falava a propósito do cinema de Fritz Lang, Otto Preminger, Joseph Losey ou mesmo Brian De Palma. "Será o fim da mise en scène?", Jacques Aumont se pergunta ao abordar $O$ Intruso (Claire Denis, 2004) na conclusão de seu livro $O$ cinema e a encenação, de 2006.

Para confrontar esses dois momentos, o de uma definição essencialista da mise en scène e o de sua dissolução no contemporâneo, a dissertação se divide em duas partes. A 
primeira, intitulada "Tudo está na mise en scène", começa com um estudo sobre a própria noção de mise en scène no cinema, levando em conta suas origens teatrais e algumas de suas aplicações diversas na teoria e na crítica cinematográficas. Examinaremos a dificuldade de encontrar uma definição unívoca para a mise en scène (ou seja, a polivalência do conceito), bem como a dificuldade de apontar - nos filmes - o que seria sua manifestação concreta. Depois analisaremos as definições de mise en scène formuladas por duas vertentes da crítica francesa concentradas nas revistas Cahiers du Cinéma e Présence du Cinéma nos anos 195060: a hitchcock-hawksiana (aqui representada por Éric Rohmer e Jacques Rivette) e a macmahonista (aqui representada, sobretudo, por Michel Mourlet, que plantou as bases teóricas do movimento). Ambas as vertentes buscaram entender o que seria a essência da mise en scène, acreditando poder encontrar, no decorrer dessa busca, o coração secreto das obras dos cineastas que admiravam e, por tabela, o núcleo pulsante da arte cinematográfica como um todo.

Na parte II, cujo título interroga “Onde está a mise en scène?”, analisaremos os filmes que se colocam naquela zona de indeterminação da mise en scène compreendida pelo conceito de estética do fluxo. Começando por um breve apanhado histórico que vai do maneirismo dos anos oitenta ao cinema-dispositivo do final da década de noventa, investigaremos quais foram as transformações que prepararam o terreno para filmes como Sombra (Grandrieux, 1998) e Gerry (Gus Van Sant, 2002), além do já citado $O$ Intruso. A análise dos textos que fundamentam a base teórica do projeto, na parte II, será acompanhada pela análise das obras que constituem nossa filmografia principal.

O cinema de fluxo nos permitirá estabelecer uma "escala" para a avaliação de nossas questões centrais: qual o lugar da mise en scène (aquela arte totalizante sobre a qual discorriam, cada um a seu modo, Mourlet, Rivette, Rohmer e outros) no cinema contemporâneo e, nos casos em que "não se pode" falar de mise en scène, qual seria seu substituto?

Embora a expressão "fluxo" possa evocar alguns conceitos de vida social e cultural na pós-modernidade, o principal objetivo deste trabalho é demarcar um terreno estético e concentrar a discussão em um motivo formal (isto é, um conjunto de procedimentos estilísticos e linhas de força que constituem uma tendência estética) que mapearemos dentro de um cenário específico do cinema contemporâneo. 
I.

Tudo está na mise en scène 


\title{
Um termo importado das artes cênicas
}

"Se há uma noção que parece aproximar a arte cinematográfica de seu antecedente teatral, é certamente a de 'mise en scène'"’3. Esta frase de Jacques Aumont resume a história que levou um termo cunhado, em sua origem, para designar uma prática teatral, a mise en scène, a ser também aplicado ao cinema já em suas primeiras duas décadas de existência. Podemos encontrá-lo, por exemplo, em escritos de George Méliès datando de 1907:

\begin{abstract}
A mise en scène é preparada de antemão, assim como os movimentos de figuração e o posicionamento do pessoal. É um trabalho absolutamente análogo à preparação de uma peça de teatro; com a diferença de que o autor deve saber por si mesmo tudo combinar no papel, e ser, por conseguinte, autor, metteur en scène, desenhista e freqüentemente ator, se ele quiser obter um todo que se sustente." 4
\end{abstract}

Embora, do ponto de vista técnico, o cinematógrafo seja uma novidade, Méliès o encara, enquanto espetáculo, menos como inovação do que como continuação. Ele o situa no prolongamento de uma prática de espetáculo de cena pré-cinematográfica. Há duas coisas a se destacar no trecho acima: primeiramente, a afirmação de que a mise en scène no cinematógrafo "é um trabalho absolutamente análogo à preparação de uma peça de teatro"; em seguida, colocaremos em perspectiva essa figura de um encenador-total, um metteur en scène que cuida de todos os detalhes do espetáculo, desde sua preparação até a encenação propriamente dita.

Méliès pertence ao que André Gaudreault denomina, na esteira de Tom Gunning, a cinematografia-atração - conceito mais específico e aprofundado daquilo a que se chama early cinema, ou cinema dos primórdios ${ }^{5}$. A cinematografia-atração, para Gaudreault, se enquadra no paradigma cultural do espetáculo de cena do fim do século XIX, composto por uma série de "diversas unidades de significação": o teatro de sombras, os esquetes de mágica, a feeria, o circo, o teatro de variedades, a pantomina etc. Cada uma dessas unidades de significação representa uma "série cultural", e seu entrecruzamento forma um contexto no seio do qual a cinematografia-atração se localiza. O que Méliès faz, portanto, é usar um

\footnotetext{
3 Jacques Aumont, em "La mise en scène: de la correspondance des arts à la recherche d'une spécifcité", introdução do livro La mise en scène, coletânea organizada por ele.

4 "Les vues cinématographiques", publicado como anexo em GAUDREAULT, André, Cinéma et attraction, Paris: CNRS Éditions, 2008, p. 206.

5 Ver principalmente Cinéma et attraction, livro em que Gaudreault atualiza e aprofunda o conceito de cinematografia-atração já trabalhado por ele anteriormente.
} 
aparelho novo para explorar seus efeitos dentro de uma modalidade cênica preexistente. Como disse Jacques Deslandes, "Méliès não é um pioneiro do cinema, mas o último homem de teatro de féerie".

Muitos estudos já se aprofundaram nas relações de continuidade entre cinema e teatro. Nosso propósito aqui é trazer as principais conclusões de alguns desses estudos para melhor enxergar de que modo a mise en scène, nascida no teatro, ganhará no cinema (ao menos na visão de alguns importantes críticos/teóricos que analisaremos mais adiante) uma dimensão de essência, de força-motriz, de fonte emanadora de toda a beleza da arte em questão. A liberdade do ponto de vista da câmera, somada aos elementos que constituem sua especificidade técnica, afastaria o cinema, em tese, do teatro, mas este continua a ser o local de onde devemos começar qualquer estudo que envolva diretamente o "levar para a cena", a cena, o espaço cênico, o espaço representado - a mise en scène. O cinema não podia se inventar sem se submeter às leis da mise en scène teatral (adaptando-as), nem que fosse para se revoltar contra elas ${ }^{6}$. Assim sendo, antes de lapidar o conceito de mise en scène tal como este se desenvolve no cinema (o transplante do termo não será unívoco, e sim revestido de deslizes de significações), buscaremos sua origem nas artes cênicas, ou melhor, naquilo que o cinema delas herda. A começar pela configuração espacial da cena, conforme Ismail Xavier destaca ${ }^{7}$ :

\begin{abstract}
A representação sempre se dá dentro de limites, tem seu espaço próprio, em oposição ao espaço de quem a observa. Essa é uma noção clássica que vale para a prática teatral dentro de certo período e estende-se ao mundo da tela. (XAVIER, 2003)
\end{abstract}

A oposição cena-espectador permite ressaltar uma continuidade entre o cinema e certa tradição bem definida de espetáculo, pelo menos como este é entendido a partir do barroco (configuração do "palco italiano", por volta de 1530: platéia toda de um lado, ação teatral do outro, separados por uma nítida fronteira) e, mais especificamente, desde os postulados do drama sério burguês elaborados por Diderot no século XVIII. Tais postulados nascem da recusa a um teatro que fazia da cena uma "recitação sob dois lustres", um teatro que a seu ver estava por demais apoiado no efeito da palavra. Esse teatro combatido por Diderot consiste na tragédia francesa clássica consolidada no século precedente.

Na França do século XVII, o classicismo de pensadores italianos renascentistas havia

Ver Aumont, O cinema e a encenação, Lisboa: Edições Texto \& Grafia, 2008, pp. 54-72.

Ismail Xavier, "O lugar do crime: a noção clássica de representação e a teoria do espetáculo", in $O$ olhar e a cena, São Paulo: Cosac \& Naify, 2003, pp. 59-84. 
sido acolhido e difundido. Em torno de uma doutrina estética retomada das interpretações da Poética de Aristóteles, surgira uma dramaturgia que buscava eficácia, beleza e energia na palavra, na linguagem, já que esta, mais que a parcela física da representação, passava a ser o fundamento da tragédia ${ }^{8}$. Os expoentes máximos dessa dramaturgia foram Corneille, Molière e Racine.

Normas estritas determinavam o código do palco na tragédia clássica. O princípio da generalidade (tributário do universalismo, fundamento do pensamento classicista) pregava a repetição de cenários padronizados e a existência de um acervo comum de figurinos reutilizados segundo a necessidade. Tal princípio orientava a cena classicista e demonstra que, no palco, era a palavra que devia reinar soberana. Mesmo quando os detalhes revelavam certo cuidado com a veracidade histórica, acima da autenticidade predominavam o gosto e o entendimento de que a arte teatral era concebida como uma arte prioritariamente do texto e da dicção. $\mathrm{O}$ debate em torno do modelo teatral ideal preconizava a dramaturgia, em detrimento da realização cênica ${ }^{9}$. O palco era simplesmente o lugar e a ocasião para se dar corpo e voz à palavra poética ${ }^{10}$. As incongruências ou inadequações reveladas pela mise en scène eram sempre remetidas às insuficiências da dramaturgia.

É contra esse modelo de teatro que Diderot se posiciona no século XVIII. Assim como Voltaire, ele quer mais ação no palco, mais ilusão realista, mais conteúdo emocional e sentimental nas tramas, mais cor local e particularidades em substituição aos preceitos classicistas. Ele pede a elaboração de um jogo cênico que enfatize a ação física da representação (o gesto, a físionomia). A cena deve se impor por sua qualidade de presença, colocando o mundo imaginário da peça ao alcance dos sentidos.

A teoria e a prática do que [Diderot] denominou drama sério burguês, distinto da tragédia, implicam, entre outras mudanças, a apresentação dos sentimentos tais como se fossem vividos naturalmente, um ir além da apresentação convencional, indireta, das paixões, método que vê como próprio do sistema das representações ao gosto do aristocrata do Antigo Regime. Tal como em outras dimensões da experiência, a cultura burguesa reivindica aqui a natureza contra a convenção, não teme o sentimentalismo e chega ao lacrimoso em sua concepção do drama como lugar da afirmação das disposições "naturais", da paixão sincera, do mundo privado, das relações familiares agora não mais atadas ao jogo de poder do Estado como na tragédia clássica. (XAVIER, 2003)

8 Cf. João Roberto Faria, "A dramaturgia do classicismo", in GUINSBURG, J., O Classicismo, São Paulo: Perspectiva, 1999.

9 Cf. Silvana Garcia, "A cena classicista”, idem.

10 Pensar na definição de Barthes para Fedra, de Racine, como uma "tragédia nominalista", onde as palavras, e não os sentimentos, é que são portadoras da desgraça. 
Contribuem para isso as mudanças que se operam no panorama histórico-social. $\mathrm{Na}$ França pós-Revolução, os teatros aos poucos vão sendo ocupados por um público heterogêneo, que já assiste aos espetáculos das feiras e do boulevard e cultiva a admiração por outros heróis, aparentados àqueles clássicos, porém mais viscerais e atraentes por conta do filtro melodramático. Nos novos rumos seguidos pelo teatro, ao esmaecimento da tragédia corresponde uma ascensão da comédie larmoyante e do drame bourgeois. O teatro popular se desenvolve e, em torno de 1800, o melodrama já se estabelece como gênero dramático. As tramas romanescas do melodrama exigem um número cada vez maior de efeitos cênicos, aumentando a preocupação com o lado propriamente espetacular da representação. Os atores vão desmontando os códigos rígidos da cena classicista. Apuram-se as exigências de referências locais e rigor histórico. Há a busca de uma maior adequação dos figurinos aos papéis: os figurinos se tornam nuançados, e não mais provêm de um acervo de peças reutilizáveis. O universalismo classicista vai aos poucos cedendo espaço à individualidade romântica, cuja expressão ideal solicita uma vida ao mesmo tempo trágica e cotidiana (esse equilíbrio entre o trágico e o cotidiano será retomado quando analisarmos o pensamento de Michel Mourlet). A dramatização serena da tragédia clássica se vê contrabalançada por uma intensidade emocional "com potência para eletrizar a platéia e esgotar o intérprete"11.

Para a construção do mundo imaginário então requerido pelo teatro, é fundamental a aquisição de técnicas que ampliem a ilusão visual do espetáculo. Somando-se a algumas características que já vinham se desenvolvendo desde os séculos XV e XVI (busca de unidade visual na cenografia, efeito-janela fundado na concepção de espaço pós-pintura renascentista que incrementa o ilusionismo realista, procura de maior adequação entre gênero e forma cênica, primeiras construções de edifícios especificamente dedicados ao teatro), essa emergência da expressão romântica e dos gêneros populares prepara o terreno para que, com as inovações da segunda metade do século XIX, os aspectos visuais e representativos da arte teatral sejam realmente reconhecidos. Em relação direta com esse reconhecimento, está o aparecimento da expressão que mais nos interessa nessa história toda, a mise en scène.

A locução metteur en scène aparece na França no começo do século XIX, mais precisamente em 1820, mas só se impõe no final do século como desígnio daquele que "põe em cena". Mobilizado pelas duas grandes tendências que se destacam nesse período (a realista e a simbolista), o encenador, o metteur en scène ganha destaque cada vez maior. Ele assumirá a responsabilidade pela unidade do espetáculo, algo que até então cabia, normalmente, ao

11 Garcia, idem. 
diretor de cena (régisseur) ou ao ator principal (conforme fazia Molière) ${ }^{12}$. Antes, a prática da mise en scène não existia tal como a pretendemos definir aqui. Mesmo no teatro barroco, onde os aspectos espetaculares são preponderantes e os elementos plásticos e visuais são centrais, não se pode identificar essa "arte da coordenação" a que nomeamos mise en scène. Se o termo já existia, não possuía o sentido e o peso que hoje conhecemos. Tratava-se então da organização material da representação: uma “direção" que, segundo Éric de Kuyper, na maior parte do tempo não passava de uma "polícia de cena"13. Mas uma necessidade latente de mise en scène se fazia sentir, como ocorria em muitos dramas românticos na França: cada peça exigia uma abordagem original para sua representação, novas soluções cênicas e cenográficas. Havia a demanda de um “espetáculo ocular". A corrente historicista do século XIX, que prega um cuidado obsessivo com a reconstituição histórica e um tratamento arqueológico aprofundado dos elementos plásticos, vem justamente suprir essa demanda, dando forma à concepção moderna (oitocentista) de cenografia: unidade espacial a serviço da transcrição cênica de um texto em particular. $O$ drama histórico é facilmente assimilado pela corrente naturalista/realista, bastando focalizar mais o cotidiano e o intimismo do que os aspectos grandiosos do passado ${ }^{14}$.

Outra corrente decisiva para o modo como o cinema assimilará a prática e a noção da mise en scène é o teatro comercial de grande espetáculo que floresce em Londres, Nova Iorque e Paris. Não é nem um teatro literário, nem ópera, mas um espetáculo popular que exige uma outra concepção de elaboração do conjunto segundo uma meta - sempre a mais espetacular possível - a atingir. Os empreendedores desses espetáculos são ao mesmo tempo produtores e metteurs en scène, e portanto atuam nos planos artístico e financeiro: eles são responsáveis pela relação entre planejamento e recursos disponíveis. O produtor/metteur en scène, assim, emerge no domínio comercial bem como no artístico. O teatro se afirma como obra do encenador; opte-se por realismo ou convenção (simbolismo), é sempre o encenador que decide. A noção de criação não se limita mais a essa fonte única e absoluta (do autor do texto ou do drama lírico), mas se refrata em diferentes pontos de criatividade que se respondem mutuamente. Em O cinema e a encenação, Aumont sintetiza bem as razões práticas e históricas dessa consolidação do encenador como figura central da criação e execução do espetáculo teatral:

As razões dessa pequena revolução são de duas ordens. Em primeiro

\footnotetext{
12 Cf. Aumont, O cinema e a encenação, p. 129.

13 "Une invention méconnue du XIXe siècle : la mise en scène", in AUMONT, Jacques, La mise en scène, Bruxelas: Éditions De Boeck Université, 2000.

14 O filão histórico-realista será continuado no cinema (Zecca, Griffith, Vidor, DeMille).
} 
lugar, as técnicas se tornam mais complexas, em especial as da iluminação; o diretor de cena, encarregado da maquinaria e do palco, não está preparado para gerir essas técnicas. Em segundo, e fundamentalmente, as convenções do teatro clássico, que "automatizam" a encenação, vão desaparecendo gradualmente. Na época de Horácio (Corneille, 1640), a tragédia implica um lugar único, uma duração verossímil, uma forma cênica pobre (poucos cenários e estilizados); o essencial está na dicção e na representação; aliás, o palco é um lugar de ostentação social. O teatro burguês, por seu lado, quer-se universal: não assenta em convenções tão rígidas o que tem como contrapartida o fato de a encenação ter de ser sempre redefinida. Enquanto que, no século clássico, a peça era levada à cena de uma maneira que não estava necessariamente indicada no texto, mas que toda a gente conhecia, no teatro romântico ou burguês pode ser montada de maneiras diferentes. Por isso, é necessário um intermediário, um intérprete, que assuma a responsabilidade dessa passagem do texto à cena. (AUMONT, 2008)

A história da encenação teatral, como colocada acima, é a do crescimento constante da função do encenador. Ao longo de todo o século XIX, o teatro se constrói muito mais na visualidade do espetáculo que na excelência de um texto poético. Cria-se uma tradição de truques, magias, efeitos espetaculares que aumentam o teor ilusionista da representação. Alterações de pano de fundo, sobreposições e outros recursos cênicos fazem do teatro uma experiência visual excitante e múltipla ${ }^{15}$. Cada peça pede um cenário diferente, um figurino, um arsenal de efeitos, uma iluminação, uma movimentação de atores, um tom de diálogo, e o responsável pela orquestração de tudo isso é o metteur en scène. "Mettre en scène é 'organizar a ação no palco', e implica controlar performance, luz, cenário, figurino e afins" ${ }^{\text {"16 }}$. A partir dos anos 1910-20, a revolução está concretizada e a arte teatral torna-se, para muitos, a arte da encenação. Esse "teatro puro" coincide com o papel central, diretor e impulsionador, do metteur en scène: ele espacializa e gestualiza o texto, para em seguida lhe acrescentar uma interpretação pessoal.

"Não é por acaso que nunca se falou tanto de 'teatralidade pura' como nas décadas em que se elaborou, paralelamente, a fórmula da longa-metragem de ficção clássica" ${ }^{17}$ : todos esses aspectos da encenação que extrapolam a dramaturgia convencional, ou seja, tudo aquilo que fora acrescentado ao teatro na passagem do drama clássico para o drama burguês (incluindo os elementos plásticos de apelo visual evidente) é continuado e fermentado no cinema. Tanto a visualidade-gestualidade quanto a tecnologia de efeitos especiais que o teatro já punha em cena no melodrama ou nas peças históricas recebem, no cinema, uma nova

15 Cf. Xavier, op. cit., p. 65.

16 David Bordwell, Figures traced in light, Los Angeles: University of California Press, 2005, p. 11.

17 Aumont, $O$ cinema e a encenação, p. 130. 
roupagem para satisfazer o mesmo tipo de público e os mesmos critérios dramáticos:

Melodrama significa ação, velocidade, efeitos ilusionistas, enredos complicados e cheios do que hoje chamamos "golpes de teatro". Mobiliza atores grandiloqüentes, gestos largos, sentimentalismo, a composição de tableaux [...] e o desenvolvimento gradual de toda uma maquinaria manipuladora de cenários e reprodutora de aparências. Esse elenco de características presentes no teatro "melô" poderiam estar aí a enumerar traços da cena cinematográfica, com rara precisão se pensarmos no cinema narrativo-dramático em torno de 1910. (XAVIER, 2003)

A mise en scène posta em prática no cinema herda, portanto, todo um século de teatro popular - o que inclui uma nova atitude em relação à técnica: "Na tradição artística até Wagner, a idéia original é pura e se realiza e se concretiza por meio e intermédio de técnicas diversas. No grande espetáculo, ao contrário, a idéia original é toda ela cheia de tecnicidade"18. Dá-se a união, nesse "grande espetáculo", dos ingredientes tradicionalmente considerados como superiores ou artísticos - a saber, o texto e os atores - aos de ordem inferior, em particular aqueles enraizados na técnica. Herdeiro desse paradigma artístico, o cinema exige que a técnica seja abordada, desde o início, por um ângulo criador. A técnica cinematográfica não se reduz a uma ferramenta: ela é aquilo que torna o espetáculo possível. O elemento técnico não apenas incrementa a ficção, não apenas agrega atrativos ao espetáculo, mas está na base de sua concepção mesma, e implica uma coordenação premeditada, um processo de feitura que deverá ser respeitado até o resultado final (a projeção em sala).

Se a técnica, no cinema, está intimamente ligada ao processo criativo, as novidades que a câmera e todo o dispositivo envolvido na filmagem/revelação/projeção trazem, logicamente, serão determinantes. Transportada do palco para a tela, a cena passa a ser um retângulo de luz que vibra numa superfície bidimensional; "se, no teatro, encenar é pôr numa cena (mettre sur une scène), no cinema tudo reporta ao quadro" 19 . A câmera e sua mobilidade ampliam os recursos expressivos, potencializando a dramaticidade dos fatos e dos gestos. $\mathrm{O}$ potencial de efeito de cada movimento, de cada olhar, de cada palpitação do corpo, que no teatro precisava do excesso e da mímica para se amplificar, tem a seu serviço, no cinema, o quadro - e o plano, em sentido mais vasto (que leva em conta duração, movimento, foco, reconfiguração permanente do quadro etc). Entra em jogo uma explicitação de sentido pela imagem, a tela funcionando como um local para o qual os significados e as emoções se

18 Kuyper, em AUMONT, Jacques, La mise en scène, p. 19.

19 Aumont, O cinema e a encenação, p. 84. 
canalizam em formato intensificado.

A necessidade do enquadramento e a possibilidade de variar o ponto de vista sobre a cena, assim sendo, determinam no cinema um novo estatuto para a realização cênica. Mas são justamente essa necessidade e essa possibilidade que permitirão à mise en scène cinematográfica ser mais que uma técnica: "graças à restrição benéfica do quadro, torna-se uma força (ou uma energia). Tudo se passa como se o quadro, ao condicionar a encenação, ao clarificá-la, ao torná-la definitiva, se tornasse uma espécie de lente que focaliza sua energia ${ }^{20 "}$. Por meio desse quadro, a mise en scène cinematográfica se faz não apenas uma colocação em cena, mas acima de tudo um olhar sobre o mundo. É isso que mais importará nos textos de Jacques Rivette, Éric Rohmer e Michel Mourlet (autores dos principais textos que analisaremos). O lado propriamente técnico só interessará de fato à medida que a técnica em questão gerar um novo acesso ao mundo sensível e, conseqüentemente, uma forma de conhecê-lo. Não é a técnica em si - embora ela seja mais que um instrumento, esteja inextricavelmente incrustada na composição do espetáculo e tenha implicações incontornáveis na maneira de organizar o material fílmico - o que determina a essência da encenação para Rivette, Rohmer ou Mourlet. Há algo mais, de difícil definição, algo não raro deduzido em valores abstratos - a exemplo da tal "evidência” que Rivette assimilará como marca sensível do "gênio" de Howard Hawks ou que Mourlet tratará como a única coisa que importa, no fim das contas, ao "olhar impassível da câmera".

20 Idem. 


\section{Lapidando o conceito}

Mise en scène: levar alguma coisa para a cena para mostrá-la. Eis uma definição possível - pragmática, por um lado, mas insuficiente e imprecisa, por outro. "Poucos termos na estética fílmica são tão polivalentes como este”, disse com razão David Bordwell ${ }^{21}$.

Vimos anteriormente que Méliès estabelecia a existência e a precedência, na prática cinematográfica, de uma figura que seria de alguma forma fundamentalmente responsável pelo conjunto das operações de feitura de um filme. Ele chega a sugerir que essa figura não pode se poupar, caso necessário, de atuar ou pelo menos demonstrar na prática como devem se comportar os atores e os figurantes:

Ele [o metteur en scène] dirige o ritmo, o posicionamento dos figurantes, e é obrigado a mostrar a cada um deles seu personagem para melhor indicar seus gestos, suas entradas, suas saídas, o lugar que devem ocupar em cena ${ }^{22}$.

A expressão metteur en scène começa a aparecer quando as metragens se alongam e os filmes começam a se complexificar, sendo feitos por várias pessoas ao invés de uma só. Surge para designar não a instância suprema da cinematografia, mas esse companheiro do operador que seria a instância responsável tanto pelo que hoje corresponde mais ou menos ao que se chama direção de arte quanto pela direção de atores. No início, a expressão mise en scène tem um sentido restrito, e parece designar exclusivamente o trabalho de regulagem da ação a filmar. Ela em seguida irá se referir também à direção do conjunto do "plateau", assim como à disposição dos cenários. Uma vez expandida, a noção de mise en scène implicará não somente "a arte de regular a ação cênica sob todas as suas faces e sob todos os seus aspectos" (Jean Giraud $^{23}$ ), mas também a direção das tomadas de vistas, ou dos quadros.

André Gaudreault ${ }^{24}$ distingue, com relação ao cinema dos primórdios, ou cinematografia-atração, três níveis de intervenção do campo de atuação cineástica: a mise en scène (grosso modo: a organização do profílmico), a mise en cadre (grosso modo: a filmagem) e a mise en chaîne (grosso modo: a montagem). Nos primeiros anos do cinematógrafo, ainda na década de 1890, a preponderância do termo "operador" no vocabulário fílmico corresponderia a uma ênfase na mise en cadre (entre outras coisas porque

${ }_{21}$ Figures traced in light, $\mathrm{p} .11$.

22 Em Gaudreault, Cinéma et attraction, pp. 219-220.

23 Citado por Gaudreault em Cinéma et attraction, p. 129.

24 Também em Cinéma et attraction. 
o realizador de filmes, nesse momento, tinha de resolver demasiados problemas técnicos de várias ordens para ter o tempo de se considerar como encenador). Na virada do século, já se observa um privilégio do termo "metteur en scène": ênfase na mise en scène, com o detalhe de que esta, tal como empregada naquele momento, consiste numa atividade, segundo Gaudreault, não especificamente cinematográfica, porquanto se sobressai na esfera do profílmico, mais do que no fillmográfico ${ }^{25}$. Essa concepção de mise en scène implica acima de tudo uma intervenção, por mínima que seja, sobre os elementos (preparação do cenário, dos atores etc) que antecedem o ato do registro em si (este será feito pelo operador através da câmera). O próprio termo "cinematografista" refletiria uma flutuação entre mise en cadre (sob a responsabilidade do operador) e mise en scène (sob a responsabilidade do metteur en scène), flutuação que acusaria a aparente falta de especificidade, nessa época, da atividade de "mise en film", uma atividade que transcende as duas operações de mise en cadre e de mise en scène. Essas duas operações permanecem provisoriamente autônomas e independentes, uma em relação à outra:

É um pouco como se ainda não se tivesse conseguido, na época, fazer a síntese entre profílmico e filmográfico, e que se os opusesse um ao outro, tanto que, na época da cinematografia-atração, é freqüentemente a mesma pessoa (Méliès representa um pouco uma exceção sobre esse capítulo) que faz ofício de operador e de metteur en scène, ao menos empiricamente. (GAUDREAULT, 2008)

Não dá para dizer exatamente quando ${ }^{26}$ (até porque isso não ocorre da noite para o dia, e sim como fruto de um processo ao longo do tempo) o termo mise en scène passará a responder pelo conjunto que dá forma e pensamento ao filme, e sua utilização bastará para evocar a tal síntese entre profílmico e filmográfico. Quando chegarmos, no próximo segmento, aos textos de Rivette, Rohmer e Mourlet publicados nos Cahiers du Cinéma nos anos 1950, perceberemos que a mise en scène àquela altura já será considerada sob o prisma de uma condensação das principais atividades ao alcance de um realizador de filmes, e não mais dirá respeito somente a um nível de intervenção dentre outros. Tudo estará na mise en scène. Mas o fato é que nesse primeiro momento, da cinematografia-atração, não se apresenta ainda de modo claro qual instância condensaria esse "tudo": apesar da utilização bastante recorrente na época, a expressão metteur en scène esteve longe de ser a única convocada para designar, em meio a todos que intervinham no filme, o indivíduo que seria o nó central do processo criativo. Sintoma disso é o número elevado de termos empregados para nomear tal

25 Não se reclama ainda, na época da cinematografia-atração, um estatuto particular para a mise en chaîne.

26 Embora saibamos que será a partir da segunda metade dos anos 1910. 
indivíduo, nenhum deles tendo se imposto de modo exclusivo: além de metteur en scène, acham-se ao longo dos anos 1910 cinematografista, cinegrafista, compositor de filmes, filmador, realizador, diretor de filmes (entre outros). Aumont acrescenta mais detalhes à história:

\begin{abstract}
Com o crescimento das ambições artísticas e da especialização das tarefas, o vocabulário desenvolveu-se e diversificou-se, segundo dois eixos - o do ofício e o da arte: havia, de um lado, o realizador e encenador (metteur en scène); do outro, cineasta e, depois, autor. "Cineasta" é o único destes termos que tem uma data de nascimento e um progenitor: em maio de 1921, no seu jornal Cinéa, Louis Delluc propõe o termo, um pouco por acaso e com o desejo confesso de substituir o termo francamente bizarro de "écraniste", que fora inventado por Canudo. Os ingleses chamar-lhe-ão filmmaker, mas outras línguas européias (espanhol, português, alemão etc) usarão o termo cineasta, por vezes em concorrência com outros. É que este termo oferece uma solução para uma verdadeira dificuldade: como designar este indivíduo de pretensões artísticas, cuja obra, porém, não resulta do trabalho solitário normal, mas de uma colaboração? (AUMONT, 2008)
\end{abstract}

Houve, portanto, dois eixos segundo os quais se abordou o indivíduo encarregado daquela operação de conjunto que, mais tarde, seria subsumida na expressão mise en scène. $\mathrm{O}$ primeiro vem representado pelo termo "realizador" (bastante comum até os dias de hoje), concebido para designar aquele que realiza, ou seja, que faz passar um argumento/roteiro/texto para a realidade sensível. "O realizador é um homem do concreto, do visível e do audível, aquele que sabe traduzir uma narrativa escrita em ações e gestos" ${ }^{27}$. Nos anos 1920, quando o termo entra no uso corrente, não está separado de "encenador" senão por nuances; ambos estão incumbidos de transferirem para a realidade atos, gestos e movimentos, a carga expressiva de um texto escrito, de um argumento ou de uma peça de teatro. Fica sugerido assim que no cinema, qualquer que seja o desígnio, realizador ou encenador, o responsável pela mise en scène teria a missão, na grande maioria dos casos, de ser o ilustrador de um texto. "A mise en scène seria então erguer ou erigir o que está sobre superfície plana (escrito!), passar do horizontal ao vertical. É, pelo viés da atualização, passar da virtualidade à realização", diz Éric de Kuyper ${ }^{28}$.

Já o segundo eixo destaca o "autor", o cineasta enquanto indivíduo plenamente consciente - e dominador - das operações artísticas que articula. O termo "cineasta" durante muito tempo criou confusão, pois designava todos (animadores, realizadores, artistas,

\footnotetext{
27 Aumont, $O$ cinema e a encenação, p. 21
}

28 La mise en scène, p. 21. 
industriais, produtores, operadores) que contribuíam de alguma forma para o cinema. É tardiamente, no decorrer dos anos 1930, que o termo consegue se impor tal como o conhecemos hoje, ou seja, como sinônimo de autor do filme. Rapidamente percebeu-se que, diferentemente da escrita ou da pintura, a arte da mise en film implicava um grande número de atividades pertencentes a registros bem distintos uns dos outros, e portanto envolvia diversos colaboradores. Quem então responderia pela feição da obra? Canudo, em seu famoso ensaio escrito em $1911^{29}$, já diz desejar que o cinematógrafo permita à "idéia diretriz superior" se manifestar e se tornar essa instância que teria a preocupação de elevar o cinematógrafo ao panteão das artes. Trata-se de tentar provar não só que a cinematografia seria uma arte, mas que o autor do filme, aquele que preparou a cena, que agenciou os personagens, que ordenou o cenário, seria um artista. Entra em pauta a intencionalidade do filmador de organizar o mostrado e agir sobre a representação, intencionalidade necessária, ao que tudo indica, para o filme se legitimar como obra de arte. É preciso que o artista "assine" sua obra, o que equivale a imprimir no material sensível do filme a particularidade do seu olhar - não estamos distantes da lógica que, nos anos 1950, vinculará a busca pela quintessência da mise en scène à noção de cinema de autor (a mise en scène será a grande ferramenta do autor, quiçá sua única efetiva).

Com o cinema, surge uma idéia da mise en scène não apenas enquanto meio - ou conjunto de meios - que viabiliza o espetáculo, mas enquanto arte em si mesma, apta a se traduzir como evidência sensível da qualidade estética de uma obra - e da de seu autor, por conseguinte. $\mathrm{O}$ conceito de mise en scène no cinema (ou na visão de cinema que estaremos trabalhando) leva em conta uma complexa dinâmica onde todos os elementos intervêm: uma concepção global do filme ancorada em dados tão técnicos e pragmáticos quanto abstratos e, não raro, líricos. Colocar em cena no cinema não se resume, no mais das vezes, a nenhuma operação isolável. Jacques Aumont chegou a uma interessante fórmula: “A mise en scène de cinema é o que não se pode ver" ${ }^{\prime 30}$. Ninguém sabe de maneira segura e universal o que faz a mise en scène no cinema:

A pesquisa de uma definição empírica, em todo caso, sempre fracassou nisso. Fizeram, conforme os humores, entrar aí tanto certas etapas da adaptação do texto - a tipagem, o cenário, o figurino, a figura dos lugares - quanto a "composição dramática", a maneira de conjugar, de declinar as figuras no espaço para atingir a expressividade máxima. Em suma, quase tudo no cinema depende,

\footnotetext{
29 Riciotto Canudo, "La naissance d'un sixième art. Essai sur le cinématographe", originalmente publicado num número da revista Entretiens idéalistes, em 25 de outubro de 1911; citado por André Gaudreault em Cinéma et attraction, pp. 133-134.

30 O olho interminável, p. 163.
} 
potencialmente, da arte da mise en scène. (AUMONT, 2004).

"Manter um olhar sobre o conjunto material e imaterial assim como sobre os detalhes materiais e imateriais, este é o trabalho dos produtores e dos metteurs en scène!”, diz Éric de Kuyper $^{31}$. Praticar a mise en scène seria então explorar ao máximo todas as possibilidades (de um texto, de um ator, de um cenário, de uma luz, de uma paisagem natural... e das relações entre eles) para atingir um efeito espetacular máximo, em germe desde o começo, porém só revelado e sentido na passagem dos materiais de base à obra posta em cena. Identificar uma "falta de mise en scène" é afirmar que a obra permaneceu abaixo, aquém das possibilidades. Se há mise en scène, por outro lado, significa que se realizaram plenamente as possibilidades contidas no material bruto.

As balizas da mise en scène, seguindo as considerações acima, dizem respeito tanto a uma pragmática artística quanto a um pensamento que orienta a obra. A arte da mise en scène é a arte de explorar a fundo todas as possibilidades que se apresentam, e nesse sentido devemos considerar que a mise en scène não progride cronologicamente na história do cinema, não evolui linearmente: ela se dá em função da finalidade de cada narrativa, do tipo de cinema a que serve, do material de que parte. Em outras palavras, podemos dizer que há mise en scène em Lumière, já que ele realizou todas as possibilidades do material de que dispunha. Do mesmo modo, pode não haver mise en scène num filme dos anos 1950, ou 1980, ou contemporâneo, caso ele permaneça abaixo daquela linha de aproveitamento dos recursos e materiais disponíveis ${ }^{32}$.

Outra precondição da mise en scène seria a seguinte: "Se há mise en scène, é porque deve haver uma cena em algum lugar, sobre a qual alguma coisa é posta, posicionada, trazida. Como o cinema - arte da reconstituição a posteriori (a montagem) - se presta a dar o sentimento de uma unidade, de uma coerência, de uma homogeneidade, todas as qualidades que fazem a cena - que são a cena?" ${ }^{33}$. A mise en scène, aqui, estaria inextricavelmente vinculada a seu núcleo nominal, a cena. "Pois a mise en scène, seu nome o indica, partiu ligada antes de tudo à cena" ${ }^{" 34}$ - não a cena de teatro, de onde ela decola, mas sua decupagem, ou seja, sua submissão à arte da duração e da variação dos pontos de vista. A cena cinematográfica se constrói pelo plano (ou soma de planos), que é sua unidade de composição

31 La mise en scène, p. 18.

32 Mais adiante veremos que Mourlet e Rohmer estão no oposto dessa concepção anti-evolucionista, uma vez que pressupõem a mise en scène como resultado de uma progressiva conquista ao longo dos primeiros quarenta ou cinqüenta anos de cinema (eles tratam o cinema mudo ora como primitivismo, ora como caricatura, outrora como arte grandiosa porém incompleta).

33 Aumont, La mise en scène, p. 7.

34 Raymond Bellour, "Figures aux allures des plans", in La mise en scène, p. 112. 
- unidade potencialmente descontínua, móvel e variável. Nesse ponto, antecipamos um dos tópicos principais da parte II, quando a interrogação sobre o lugar da mise en scène no cinema contemporâneo começará pela interrogação do lugar da cena e da decupagem ${ }^{35}$. Já na virada dos anos 1990 para os 2000, Raymond Bellour ${ }^{36}$ falou de uma impossibilidade, no contemporâneo, de definir frontalmente o que é a mise en scène: sua definição só se esclareceria pela separação em relação a tudo aquilo que, no cinema tal como se desenvolve hoje, transborda a definição de mise en scène, anula-a, desloca-a, podendo ir justo a negá-la e a destruí-la. Ele sugere, portanto, que o momento atual favorece uma espécie de ontologia negativa da mise en scène: defini-la não a partir daquilo que ela é, mas sobretudo a partir daquilo que ela definitivamente não é. Nada mais justo, se concordarmos que a mise en scène de cinema é de fato o que não se pode ver - e no entanto está lá, participa da evidência do filme, é essa evidência.

Cf. Jean-Marc Lalanne, “C'est quoi ce plan?” (“Que plano é esse?”), Cahiers du Cinéma no 569.

36 Idem. 


\section{A quintessência da mise en scène}

A partir da criação da revista Cahiers du Cinéma, em 1951, o debate estético em torno do cinema irá se acirrar e adensar, tendo a mise en scène como cifra mais elevada de um certo número de idéias "pregnantes na franja intelectual e ativa da crítica"37:

A idéia do autor de filmes; a idéia do cinema como uma arte dos corpos figurados em seu "verdadeiro" meio, uma arte paradoxal da evidenciação da beleza do mundo real; uma idéia do cinema como arte eminente da captação de momentos de graça e de verdade, através dos comportamentos e dos gestos reproduzidos "tais quais", sem trucagem, sem traficagem, graças à virtude de inocência e de verdade da câmera. O metteur en scène deveria encarnar um sentimento do mundo através das figuras de corpos de atores fotografados em seus movimentos e em seu meio. (AUMONT, 2000)

Surgem estéticas, manifestos, críticas, axiomas - muitos dos quais ainda permanecem reveladores - que fazem deste período ${ }^{38}$ um dos mais férteis do ponto de vista de uma história das idéias sobre a arte cinematográfica. Assinados por Éric Rohmer, Jacques Rivette, Fereydoun Hoveyda, Alexandre Astruc ou Michel Mourlet ${ }^{39}$, são publicados autênticos manifestos da mise en scène como essência e valor estético específico do cinema. (Um dado curioso a se destacar é que, para defender o cinema como arte específica, que concretiza aquilo que antes dele era impossível e inventa sensações novas, a palavra-chave será justamente aquela, mise en scène, que melhor acusa seus antecedentes teatrais, conforme já abordamos nos capítulos precedentes.)

Desde seus primeiros números, os Cahiers du Cinéma se notabilizam por tentar traduzir a paixão pelo cinema em reflexão estética e escritos conceituais. A começar por André Bazin, um dos fundadores da revista e o principal pensador do cinema como arte realista. Conforme Antoine de Baecque salienta em sua introdução a uma antologia de textos dos Cahiers, Bazin exerce uma influência determinante sobre um grupo de "discípulos" que escrevem na revista com a mente e o olhar voltados para essa "impressão de realidade" que ordena o conjunto da técnica cinematográfica e dá sentido à arte do século $\mathrm{XX}^{40}$.

37 Cf. La mise en scène, pp. 8-9.

38 Trabalharemos, principalmente, com o decênio que vai de 1951 (ano de criação da revista Cahiers du Cinéma) a 1961 (ano de consolidação da revista Présence du Cinéma).

39 Os textos de Rivette, Rohmer e Mourlet analisaremos logo a seguir. Os de Hoveyda e Astruc seriam, respectivamente, "Les tâches du soleil" (Cahiers du Cinéma $\mathrm{n}^{\circ}$ 110, agosto de 1960) e "Qu'est-ce que la mise en scène?" (Cahiers du Cinéma no 100, outubro de 1959).

40 Cf. Baecque, Teoría y crítica del cine, pp. 29-32. 


\begin{abstract}
Não resulta indiferente, portanto, que as três principais questões teóricas plantadas, entre 1951 e 1956, por Éric Rohmer, Jacques Rivette e Jean-Luc Godard derivem dos princípios bazinianos. O primeiro, em "Vanité que la peinture" $\left(\mathrm{n}^{\mathrm{o}} 3\right)$, proclama a superioridade definitiva do cinema em nome de um realismo que é inclusive o único a assumir e transmutar-se numa forma espiritual. $\mathrm{O}$ segundo, em "L'âge des metteurs en scène" $\left(\mathrm{n}^{\circ} 31\right)$, afirma a imposição da forma e da organização rigorosa que a ordena e conduz: a mise en scène. O terceiro, em "Montage, mon beau souci" ( ${ }^{\circ}$ 65), faz da aproximação entre duas imagens, entre dois planos, a questão teórica mais importante do momento, uma chave conceitual que o cinema oferece ao século para pensar-se a si mesmo. Realismo, mise en scène e montagem são desde então os três pilares da reflexão teórica dos Cahiers du Cinéma. (BAECQUE, 2005)
\end{abstract}

Com relação a Godard, é preciso frisar que ele retrabalhava a herança baziniana sem ortodoxia, cultivando um certo "espírito de contradição": onde Bazin dizia plano-seqüência, Godard se perguntava se a decupagem clássica não cairia melhor (ver "Défense et illustration du découpage classique", Cahiers du Cinéma $\mathrm{n}^{0}$ 15, setembro de 1952), onde Bazin bradava "montagem proibida", ele enaltecia o poder do corte ("Montage, mon beau souci", Cahiers $d u$ Cinéma $\mathrm{n}^{\circ} 65$, dezembro de 1956).

Desses três pilares conceituais citados por Antoine de Baecque, a mise en scène ocupará o lugar mais estratégico, atrelando-se à "política dos autores". Godard atribui a Rivette a introdução do termo na redação dos Cahiers: "Na época, falava-se do assunto do filme quando o filme 'tratava' de um assunto. Nós chegamos com a idéia de 'mise en scène', trazida por Rivette, expressão vinda do teatro que ele impôs ao cinema"41.

No que concerne a mise en scène, a "política dos autores" inventada pela ala jovem da redação dos Cahiers du Cinéma possuía uma interessante premissa, hoje bastante conhecida, segundo a qual era justamente em Hollywood, sob a pressão de grandes produtores e no seio de um conjunto de regras técnicas e profissionais, que a assinatura de um autor podia provar que seu lugar de inscrição era mesmo a mise en scène. Não raro privado da escrita do roteiro e/ou impedido de exercer qualquer controle sobre a montagem, ao diretor hollywoodiano só restava concentrar sua expressão artística individual naquele conjunto de fatores - incluindo iluminação, performances dos atores, gestual, enquadramento, decupagem, angulação etc que ele podia controlar durante a filmagem, no ato da encenação. Em suma, restava-lhe a mise en scène. No âmbito da crítica e da reflexão teórica sobre o cinema, a "política dos autores" era uma maneira de "associar de um modo irreversível a adesão a um cineasta e a compreensão de seu universo formal, pessoal; para dizê-lo em poucas palavras: sua visão do

${ }_{41}$ Ver "L'art à partir de la vie", entrevista a Alain Bergala, em Godard par Godard: Les années Cahiers (1950 à 1959), Paris: Flammarion, 1989. 
mundo"42. E como um cineasta expressa sua visão do mundo? Para os textos fundadores da política dos autores, só há uma resposta: pela mise en scène. A única política dos Cahiers consistirá então em falar da estética dos filmes, da sua realização. A moral de um filme, seu conteúdo, sua mensagem, está intimamente relacionada à forma cinematográfica empregada pelo autor (enquadramentos, movimentos de câmera, montagem etc). Desfaz-se a hierarquia entre grandes e pequenos temas, boas e más mensagens. "O que define um grande filme, o que impõe um grande tema, o que faz com que chegue uma mensagem, é a verdade de sua mise en scène" ${ }^{\dddot{4}}$.

Não é de surpreender que tal arte [a da mise en scène] tenha sido reivindicada como a própria essência - a parte mais nobre, e até mesmo a única que conta realmente - da arte do cinema. Não foram esquecidas as declarações inflamadas provocadas, em toda uma parte da crítica francesa, por essa reivindicação, dos "hitchcockhawksianos" aos mac-mahonianos. (AUMONT, 2004)

Por hitchcock-hawksianos, leia-se o núcleo Cahiers da Nouvelle Vague, os chamados "jovens turcos": Rivette, Rohmer, Chabrol, Truffaut, Godard. Eles jamais perdiam a chance de pôr nas alturas as obras de realizadores norte-americanos que consideravam geniais, mas que o restante da crítica, sobretudo francesa, desprezava ou tratava com desdém. Além de Howard Hawks e Alfred Hitchcock, havia também Nicholas Ray, Otto Preminger, Anthony Mann, Elia Kazan, o Fritz Lang das “séries B”. Já em 1955, devido à polêmica em torno de uma edição dos Cahiers dedicada a Hitchcock (choveram cartas difamando a redação, além de algumas violentas declarações feitas por "colegas" de outros veículos, Georges Sadoul entre eles), André Bazin, que nos seus últimos anos de vida cuidou de questionar a política dos autores fomentada por seus discípulos ${ }^{44}$, fez a pergunta: "Como se pode ser hitchcockhawksiano?" (título de um texto seu publicado nos Cahiers du Cinéma $\mathrm{n}^{\mathrm{o}} 44$ ). Para Bazin, os “jovens turcos” estavam preocupados menos em justificar suas preferências com argumentos racionais do que em "escandalizar com admirações e afirmações abruptas". Ele faz questão de esclarecer nesse texto a postura da direção dos Cahiers com respeito ao assunto: "nenhum dos responsáveis por esta revista compartilha o entusiasmo de Schérer ${ }^{45}$, de Truffaut, de Rivette, de Chabrol ou de Lachenay com respeito aos diretores em questão e tampouco, por outro lado, para além dessas admirações pessoais, o sistema crítico implícito que os proporciona coerência e solidariedade". Se Bazin e os hitchcock-hawksianos concordam em relação a

\footnotetext{
42 Antoine de Baecque, no prólogo de La política de los autores, p. 20.

43 Idem, p. 21.

44 Ver principalmente "De la politique des auteurs", Cahiers du Cinéma n $\mathrm{n}^{\circ}$ 70, abril de 1957.

45 Pseudônimo com que Rohmer assinava seus primeiros textos.
} 
Bresson, Renoir ou Rossellini, o mesmo já não se pode dizer quanto a Os Homens Preferem as Loiras (Hawks, 1953) ou Janela Indiscreta (Hitchcock, 1954). Mas Bazin deixa claro que considera a postura crítica dos jovens turcos "fruto de uma opinião respeitável e fecunda". Entre ele e os hitchcock-hawksianos há em comum a recusa a reduzir o cinema àquilo que ele expressa, isto é, de não avaliar a grandeza de um filme somente através do assunto e da mensagem, mas sobretudo através dos meios empregados para exprimi-los: "se [os hitchcockhawksianos] têm tanta estima pela mise en scène é porque em grande medida percebem nela a própria matéria do filme, uma organização dos seres e das coisas que constitui em si mesma seu sentido, e me refiro tanto ao moral como ao estético" (Bazin).

Já os mac-mahonianos (ou mac-mahonistas) representam outra turma: Michel Mourlet, Pierre Rissient, Jacques Lourcelles, Jacques Serguine e mais um grupo restrito de cinéfilos-críticos que freqüentam a sala de cinema Le Mac Mahon e em 1959 fundam a revista Présence du Cinéma (primeiramente em formato de folhetim, e depois, a partir do número 9, publicado em dezembro de 1961, em encadernação). Partindo dos preceitos plantados em "Sobre uma arte ignorada" (texto de Michel Mourlet que lança as bases teóricas do movimento, e que será analisado mais à frente), os mac-mahonistas passarão do cineclubismo à crítica e sistematizarão, "até o delírio" (Aumont), o pensamento sobre a mise en scène:

\footnotetext{
Ora, talvez seja mesmo o mac-mahonismo que, em sua excessiva crença em uma pureza da mise en scène, crie o mais límpido de seus modelos. Por exemplo o seguinte, na voz de Michel Mourlet: "Se o acordo de um gesto e de um espaço é a solução e a conquista de todo problema e de todo desejo, a mise en scène será uma tensão rumo a esse acordo, ou sua imediata expressão". [...] a mise en scène é um ordenamento do real, já que o cinema "não é obrigado, como as outras artes, a deformar o real para expressá-lo". Portanto, a mise en scène, concebida como alma do cinema, expressa o real, mas imediatamente. Correlativamente, toda a arte do cineasta se reduz a deixar se desenrolar justamente um gesto em um espaço, pois esse acordo é também a lei do mundo real: o mac-mahonismo é também uma ética e até mesmo, ai de mim, uma política. (AUMONT, 2004)
}

O ideal de beleza da mise en scène, para os mac-mahonistas, estará espalhado pelos filmes de um grupo seleto de cineastas, dentre os quais quatro nomes se destacarão ainda mais, formando a "quadra de ases" do Mac Mahon: Fritz Lang, Raoul Walsh, Otto Preminger, Joseph Losey. Se os três primeiros já eram cineastas tidos como grandes por outras correntes críticas (hitchcock-hawksiana inclusa), este último, Joseph Losey, é uma novidade 
eminentemente mac-mahonista - quase uma "invenção" deles (de fato, a distribuição na França de alguns dos principais filmes da primeira fase da carreira de Losey, a exemplo de $A$ Sombra da Forca [Time Without Pity, 1957], ocorre por conta da iniciativa de Pierre Rissient, que então começa carreira como distribuidor independente).

Os mac-mahonistas estiveram próximos dos Cahiers durante um curto período, entre 1959, ano de "Sobre uma arte ignorada", e 1960, quando um número especial dedicado a Losey é deixado a cargo deles. Jacques Serguine, ao final de seu texto da edição Losey ${ }^{46}$, escreve um "P.S." em que explica o sentido do mac-mahonismo:

O que é o "Mac Mahon" objetivamente? É uma sala de cinema situada na avenida Mac-Mahon, perto da Place de l'Étoile. Ela constantemente exibiu versões originais, e as melhores visíveis em Paris. Em 16 de março de 1960, tornada sala de exclusividade, ela começou sua nova carreira com a projeção de Moonfleet, um Fritz Lang de 1954, que ninguém até então tinha podido ver, a não ser em províncias privadas ou projeções restritas. [...] Aquilo de que o "Mac Mahon" parece ser o centro geométrico não é o cinema mundial, mas uma idéia de cinema. Vê-se que isso não engaja nada, a não ser talvez a amizade. A amizade pode não ser nada além de uma exigência partilhada. Donde o que se segue é que o "Mac Mahon" não é de jeito nenhum uma escola estreitada em funil, mas bem antes um ponto de partida, esse funil ao avesso. [...] Então, ser "Mac Mahoniano" é um novo esnobismo? Há sempre etiquetas para aquele que busca a beleza, esse outro nome da verdade. [...] Não me parece importante perguntar: como se pode ser Mac Mahoniano? O que importa é refletir: como se pode ser Raoul Walsh? E Fritz Lang, e Joseph Losey? Eu ainda não sei. Eu sei que eles são, e nada mais. O belo é a evidência do belo, eis o paradoxo. O "Mac Mahonismo" não é uma resposta fácil, demasiadamente fácil; é uma questão exigente. A questão, Senhores, permanece aberta. (SERGUINE, 1960)

A Présence du Cinéma (da qual Mourlet seria o redator-chefe) publica vinte e cinco números - com edições devotadas não apenas aos quatro ases, mas também a realizadores como John Ford, Samuel Fuller, Vitorio Cottafavi, Blake Edwards, Jacques Tourneur e outros - antes de desaparecer em 1967.

Debruçaremo-nos agora sobre o que uma pequena parte dessas duas correntes críticas (se é que assim podemos chamá-las) produziu de essencial naquele período cujo ápice se deu em torno de 1960. Nosso foco preconizará os principais textos ${ }^{47}$ de três autores, Rivette,

46 "Educação do espectador (ou a escola do Mac Mahon)", Cahiers du Cinéma no 111, setembro de 1960. O texto, que é uma espécie de segundo manifesto do mac-mahonismo (o primeiro, evidentemente, é "Sobre uma arte ignorada"), encontra-se traduzido para o português no dossiê Losey da Contracampo n 92 , setembro de 2008 (http://www.contracampo.com.br/92/artloseyserguine.htm).

$47 \mathrm{O}$ critério de importância dos textos, evidentemente, diz respeito aos interesses deste trabalho, e não à importância que tiveram para a história da crítica de maneira geral. 
Rohmer e Mourlet, cujos pensamentos se tocam em diversos pontos, mas se afastam em tantos outros.

\section{Jacques Rivette: “O que é, é."}

O primeiro texto de Jacques Rivette que devemos destacar consiste numa das pedras fundadoras da "política dos autores": o artigo "Génie de Howard Hawks", publicado nos Cahiers du Cinéma no 23 em maio de 1953.

O tom do texto pode ser resumido nas seguintes frases, que aparecem ainda no início: “A evidência é a marca do gênio de Hawks; Monkey Business é um filme genial e se impõe ao espírito pela evidência" (p. 16). E mais adiante: "Reconhecemos aqui uma concepção clássica do homem, que só encontra a grandeza através de experiência e maturidade; ao fim de seu percurso, sua velhice irá julgá-lo" (p. 17). Hawks seria um cineasta da "inteligência e do vigor, mas conjuntamente das forças obscuras e das fascinações", algo que os heróis exprimem "menos por seus sentimentos que por seus gestos, que ele persegue com uma atenção aguda e apaixonada; ele filma ações, especulando sobre o poder de suas aparências".

Se há uma marca característica de Hawks, ela deve ser buscada, segundo Rivette, na parcela puramente física do filme, no que este tem de mais imediato, de mais associado à ação, ao gesto, à vibração do mundo na pele do homem à medida que ele reage às modulações do espaço. Os planos se seguem "ao ritmo das pulsações do sangue", uma "respiração ágil e profunda": o espaço-tempo e o gestual são regidos por uma lei biológica. O espaço contém e exprime o drama; as variações do cenário modelam a continuidade do tempo. "Os passos do herói traçam a figura de seu destino" (p. 20). O primordial, portanto, é da ordem da ação. O conflito, o combate corporal, as lutas calorosas são o meio natural dos heróis de Hawks. Da luta nasce inclusive a estima (não há forma melhor de se fazer amizade, no cinema de Hawks, do que trocar uns socos). Rivette faz também um elogio da desmesura, do ousar o excesso como meio de fascinação.

Evidência, fascinação, ações, combate corporal, poder das aparências, espaço que exprime o drama: é importante notar, desde já, que as palavras-chave de Rivette serão retomadas, mais tarde, por Michel Mourlet.

O grande mérito artístico de Hawks, na visão rivettiana, seria uma "inteligência artesanal". Conforme Rivette desenvolverá num outro texto (dessa vez sobre Preminger), a inteligência artesanal consiste em "saber julgar seus materiais e, seguindo o conselho célebre, 
nem sempre rejeitar os medíocres, mas utilizá-los tendo conhecimento da parte exata de sua mediocridade" ${ }^{48}$. Em posse de tal inteligência, o cineasta se evade da perfeição e se põe à caça de uma "qualidade da imperfeição". A inteligência artesanal de Hawks se aplica diretamente ao mundo sensível: "Ele prova o movimento ao andar, a existência ao respirar. O que é, é."49.

Em “Génie de Howard Hawks", Rivette aborda questões mais afeitas à ontologia que à estilística. Onde buscar o estilo de Hawks, aquilo que se aproximaria de um traço hawksiano? Em nenhum lugar outro que não na sensação física da imagem. Como diria Éric Rohmer décadas depois: "O essencial não é da ordem da linguagem, mas sim do ontológico" 50 . A mise en scène de Hawks está menos na escritura que na evidência sensível do filme. Hawks é um gênio não porque domina uma linguagem, constrói uma obra de maneira virtuosa ou articula idéias elevadas: ele tão-somente imprime na película um "sentimento severo da existência"; mesmo nas comédias, filma "a trama das responsabilidades", nos dá a sentir o peso do mundo, sua gravidade.

Dois anos mais tarde, em "Lettre sur Rossellini" (Cahiers du Cinéma no 46, abril de 1955), Rivette expande essa idéia de uma mise en scène que não está na maneira nem na linguagem, mas em algo mais simples e mais profundo ao mesmo tempo, agora abordando o realizador de Stromboli e Viagem á Itália:

[...] gostaria de fazer-lhes tocar (com os dedos) os verdadeiros poderes desse olhar: que não é talvez o mais sutil, este é Renoir, nem o mais agudo, este é Hitchcock, porém o mais ativo; e não é também que ele se agarre a alguma transfiguração das aparências, como Welles, nem à sua condensação, como Murnau, mas à sua captura: uma caça de cada instante, a cada instante perigosa, uma busca corporal (e portanto espiritual: uma busca do espírito pelo corpo), um movimento incessante de captura e de perseguição que confere à imagem algo de vitorioso e de inquieto ao mesmo tempo: a inflexão mesma da conquista. (RIVETTE, "Lettre sur Rossellini", 1955)

O olhar de Rossellini merece ser exaltado porque é essa captura imediata e imprevisível do mundo: "não se sabe o que vai ser, quando, como; pressente-se o evento, mas sem vê-lo progredir; tudo nele é acidente, logo inevitável; o sentimento mesmo do porvir, na trama impassível daquilo que dura". O que se põe diante da câmera em Stromboli, Alemanha Ano Zero ou Viagem à Itália é uma espécie de substância inflamável do presente (por isso sua caça é "perigosa"), e é a essa propriedade mesma da matéria que Rossellini se acha imantado

48 Cf. "Sainte Cécile", Cahiers du Cinéma, no 82, abril de 1958, p. 53.

49 "Génie de Howard Hawks", p. 23.

50 Ver entrevista que abre o livro Le goût de la beauté. 
(não à toa, Jean Douchet o definiu certa vez como um "poeta do fogo" ${ }^{51}$ ).

Se Hawks emprestava à sensibilidade moderna uma consciência clássica, Rossellini já será a consciência moderna por excelência. Sua sensibilidade também se definirá por um vocabulário pouco afeiçoado à estilística: “[Rossellini] não busca nenhum estilo pessoal, ele é inimitável; ele se autoriza o esboço, ele se autoriza até a permanecer um amador, porque sua meta não é a obra mas o ensaio" ${ }^{\text {2 }}$. Para Aumont, o coração desse artigo de Rivette é um anticlassicismo. Ele classifica "Lettre sur Rossellini”" como um manifesto em favor de uma modernidade cinematográfica nascida de si mesma (ou seja, não derivada de uma era clássica anterior nem resultante de uma história que havia começado com o primitivismo): "a modernidade que Rivette descreve não é uma modernidade teórica, não é a declaração de um historiador de arte constatando a sucessão mais ou menos canônica dos períodos, é o credo, panfletário e radical, de um artista que se quer contemporâneo, é quase um gesto vanguardista em sua radicalidade" ${ }^{53}$. Essa modernidade tampouco é o novo ciclo de uma "tradição da ruptura". Rossellini é a modernidade em si, e por isso mesmo desponta como um modelo para Rivette. Ele está mergulhado em seu tempo, imerso na textura de sua época. A forma que ele busca está aí, nessa "trama impassível". O que há para se aprender de Rossellini, sua lição, não é uma técnica, nem um estilo de mise en scène, mas uma atitude do olhar ${ }^{54}$.

Novamente estamos diante de uma inteligência que se aplica diretamente ao mundo sensível, como ocorria em Hawks. Há uma exigência do artista em se ater às matérias naturais e em respeitar a anterioridade delas. Mas isso não basta:

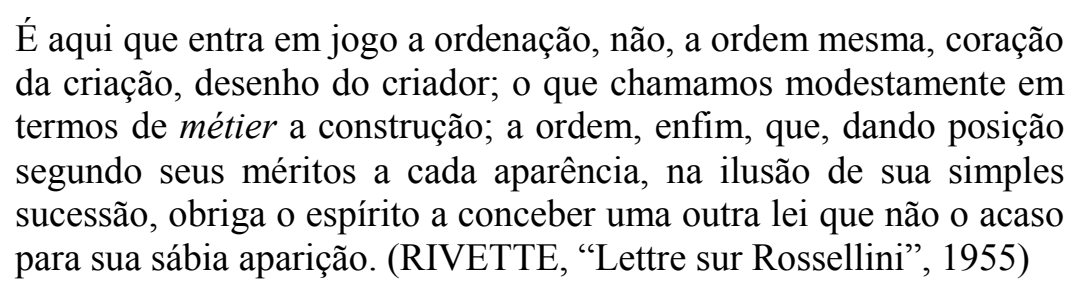

Se inicialmente a arte de Rossellini consiste na atenção meditativa concedida à matéria, no momento seguinte seu processo de realização será o "desenho", isto é, o ato de imprimir na matéria, na própria desordem empírica das aparências, o conceito formado no espírito, conceito derivado da contemplação dos dados concretos. Da imanência, do acaso, do

51 Cf. L'art d'aimer, Paris: Éditions de l'Etoile, 1987.

52 Jacques Aumont, Moderne?, Paris: Ed. Cahiers du Cinéma, 2007, p. 49.

53 Idem, p. 49.

54 A estrutura narrativa (literalmente) culminante de Stromboli, no entanto, faz Aumont indagar se o sublime da cena final não o transformaria num "grande filme romântico, ou seja, visando menos uma atualidade que uma eternidade, uma intervenção menos sobre o presente do que sobre o presente eterno” (Moderne?, p. 52). 
“sentimento mesmo do porvir", passa-se ao seu campo não contrário porém complementar, que é o da forma e da finalidade do ser. É como se o espírito devolvesse à natureza uma forma que descobriu nela mesma. A força de invenção e de imaginação de Rossellini será tão mais presente para Rivette quanto mais se unir a "uma matéria miraculosamente viva, capturada intacta em sua origem", matéria cuja atividade inerente, presença sem significação a priori, encontra um ponto de interseção e equilíbrio com a atividade enformadora do espírito. "Rossellini não demonstra, ele mostra" $"$. As coisas são em si, primeiramente, e é preciso tentar chegar à imagem que elas trazem nelas mesmas. $O$ desenho perfeito começa na aquisição dessa imagem, e completa-se no traço revelado no intelecto humano (por Deus?). A arte de Rossellini pertenceria ao "reino das verdades sensíveis, que são ainda mais verdadeiras. Eis visivelmente sob nosso olhar a beleza, o amor, a maternidade, a morte, Deus" ${ }^{" 56}$. As aparências do mundo físico seriam uma via de acesso ao que se agita no interior delas - a alma, a idéia. Um cinema verdadeiramente da "encarnação": "o cinema de Rossellini é um cinema de idéias, mas dadas sem prova, somente mostradas, pelo modo da evidência", pela presença de corpos carnais ${ }^{57}$.

No mesmo ano de "Lettre sur Rossellini”, Rivette escreve um artigo intitulado "Notes sur une révolution", publicado num número especial dos Cahiers sobre o cinema hollywoodiano ${ }^{58}$. Para afirmar que, após passar pela era dos atores e dos produtores, Hollywood chegou à era dos autores, Rivette diz que não necessita de teorias rebuscadas, mas apenas de nomes: Nicholas Ray, Richard Brooks, Anthony Mann, Robert Aldrich - os quatro que, a seu ver, em plena metade dos anos 1950, representam o fio condutor incontestável dos novos rumos da indústria hollywoodiana. Indicando quais seriam as características gerais comuns a esses quatro cineastas, ele diz que:

A violência é sua primeira virtude; não essa brutalidade fácil que fez o sucesso de um Dmytryk ou de um Benedek, mas uma cólera viril, que vem do coração, e jaz menos no roteiro e na escolha dos episódios do que no tom da narrativa e na técnica mesma da mise en scène. A violência não é nunca um fim, mas o mais eficaz dos meios de aproximação, e esses socos, essas armas, essas explosões de dinamite não possuem meta outra senão vencer os escombros acumulados dos hábitos, furar uma brecha: enfim, abrir os mais curtos caminhos. E o recurso freqüente a uma técnica descontínua, acidentada, que recusa as convenções da decupagem e do raccord, é uma forma dessa "superioridade desajeitada" de que fala Cocteau, nascida da necessidade de uma expressão imediata que dê conta e

55 Rivette, "Lettre sur Rossellini”, p. 20.

56 Idem.

57 Aumont, Moderne?, p. 48.

58 Cahiers du Cinéma n ${ }^{\circ}$ 54, "Situation du cinéma Américain", dezembro de 1955. 
faça partilhar da emoção primeira do autor. (RIVETTE, "Notes sur une révolution", 1955)

Em defesa de toda uma nova geração de diretores americanos, Rivette pauta seus argumentos principalmente sobre a rejeição, por parte deles, da retórica tradicional do roteiro e da mise en scène. A violência é signo exterior de ruptura: aos olhos de Rivette esses cineastas são todos filhos de Orson Welles, que teria sido o primeiro a ousar "recolocar em evidência uma concepção egocêntrica do metteur en scène". O "golpe de estado wellesiano" havia preparado o terreno para o cinema de autor se exercer a pleno vapor em Hollywood.

Além daquela violência pulsional anteriormente descrita, o outro pólo de criação dos novos diretores admirados por Rivette é o da reflexão:

A meta da violência é, pulverizadas as ruínas das convenções, estabelecer um estado de graça, uma vacância, no seio da qual os heróis, desligados de todo entrave arbitrário, estarão livres para se interrogar e aprofundar seu destino. Assim nascem essas longas pausas, esses retornos, que fazem o centro dos filmes de Ray, Mann, Aldrich, Brooks. A violência é então justificada pela meditação, uma e outra tão sutilmente ligadas que seria impossível separá-las sem anular a própria alma do filme. Essa dialética dos temas se reencontra em termos de mise en scène: aquela da eficácia e da contemplação. (RIVETTE, "Notes sur une révolution", 1955)

Eficácia e contemplação aparecem aqui como eixos centrais da mise en scène. Após enumerar as características individuais de cada cineasta elogiado pelo texto (o selo de um novo "mal do século" em Ray; Brooks como um "repórter fincado no universo da civilização cotidiana"; Mann renovando "o elogio da vontade e do esforço que fez a grandeza do antigo cinema americano"; "a descrição lúcida e lírica de um mundo em decadência, asséptico, metálico, sem saída", em Aldrich), Rivette termina por reunificá-los sob as seguintes atitudes: retornar ao lirismo, aos sentimentos fortes, ao melodrama, reencontrar uma certa amplidão dos gestos, uma exteriorização dos sentimentos mais despojada e mais espontânea; "enfim, reencontrar a inocência (naïveté), sinônimo de clarividência, contrário das armadilhas e artimanhas dos roteiristas profissionais". Está muito clara a posição de Rivette: contra a roteirocracia, a favor da mise en scène enquanto expressividade irrefreada, direta, ampla, corpórea, liberta o máximo possível das convenções e dos códigos, jorrada de uma fonte de violência originária. Mise en scène como linguagem não domesticada, selvagem, quiçá como anti-linguagem. $\mathrm{O}$ assunto está longe de se encerrar por aqui, e será retomado. 


\title{
Éric Rohmer: só o belo é verdadeiro
}

Herdando a "soma de André Bazin", cujas principais premissas seriam reunidas no artigo "A evolução da linguagem cinematográfica" 59 , Éric Rohmer desenvolve uma série de textos de abordagem estética e histórica que desembocam numa definição classicista do cinema. Ao lado de Godard, Rohmer foi "o grande germanista da Nouvelle Vague, não somente por causa do cinema alemão (Murnau, Lang), mas também da cultura alemã (arte, filosofia, literatura) e de sua história política" ${ }^{60}$. Como Winckelmann, Schiller, Goethe, Hegel e outros alemães fizeram em outros séculos, Rohmer vai buscar na concepção grega da arte e da vida a inspiração para seu "gosto pela beleza".

O primeiro texto dele que trata de questões que diretamente nos interessam é "Le cinéma, art de l'espace”. Nesse artigo, originalmente publicado em La Revue du Cinéma nº 14 (junho de 1948), o cinema é já considerado mediante a oposição clássico-moderno, e já incluído em um sistema evolutivo em que será constantemente relacionado com as artes que o precederam:

\begin{abstract}
O espaço cinematográfico se definiu assim em relação ao da cena a um só tempo pelo estreitamento da superfície de visibilidade e pela extensão do lugar da ação; não é, portanto, só o interior de cada um dos planos que o realizador deve determinar em função de uma certa concepção da espacialidade, mas a totalidade do espaço filmado. (ROHMER, 1948)
\end{abstract}

Na comparação do espaço cinematográfico com o das artes cênicas, Rohmer chega à conclusão de que a bidimensionalidade da imagem é compensada pela possibilidade (e pela necessidade) de fazer a cena extravasar o conteúdo visual do plano, abarcando suas imediações. O que o teatro fornece pela configuração visível do palco, o cinema pode fornecer pela variação dos pontos de vista da câmera, criando o espaço tanto pela concretude do que é mostrado quanto pelo prolongamento virtual da cena para além das bordas do quadro. O quadro de cinema "não circunscreve senão provisoriamente uma porção mais ou menos extensa da superfície onde se desenvolve a ação". A unidade da cena cinematográfica não depende só do que é enquadrado/focalizado. O lugar da ação se faz mais amplo, porque inclui não apenas o fora-de-campo concreto (aquela porção de espaço contígua ao plano, ainda que não apreendida no campo de visão) como também toda a idéia de espaço criada

59 Qu'est-ce que le cinéma? - I: Ontologie et langage, Paris: Éditions du Cerf, 1958.

60 Cf. Charles Tesson, "Peut-on être rohmero-rivettien?", Cahiers du Cinéma n ${ }^{\circ}$ 653, fevereiro de 2010 (a edição homenageia Éric Rohmer, que havia falecido no mês anterior). 
pela diegese (o fora-de-campo imaginário, por assim dizer). A mise en scène, por conseguinte, diz respeito a todo esse espaço, e não apenas ao que está circunscrito no quadro.

Rohmer afirma que os procedimentos espaciais estariam se tornando menos aparentes no cinema moderno (em Rossellini, por exemplo, ele vê uma riqueza de expressão espacial, mas num sentido bem diferente daquele da deformação plástica que ocorria no expressionismo alemão): "É normal que a evolução do cinema se produza, como a de todas as outras artes, no sentido de uma economia dos meios de expressão". Aqui ele inclui o cinema em um sistema idealista das artes segundo o qual o progresso de uma atividade artística ocorre sempre no mesmo sentido, que é o de uma economia dos meios expressivos. Certos realizadores, segundo Rohmer, estariam abrindo a via de uma nova estilística mais pobre em aparência, porém liberta de um certo número de "sobras visuais", o que permitiria uma organização mais rigorosa do conteúdo dramático em função do modo de expressão adotado. Em suma, haveria uma diminuição da importância dada à plasticidade e uma maior concentração de esforços na construção dramática e cênica; a atenção estaria mais voltada para o drama e a mise en scène do que para a composição gráfica da imagem. A valorização dessa apreensão imediata do mundo (ou seja, uma apreensão cujos meios não se fazem tão presentes, ou cujos "procedimentos espaciais se tornam menos aparentes"), em detrimento da dimensão puramente plástica da imagem, será uma das regras fundamentais da mise en scène defendida por Michel Mourlet; sua crítica ao expressionismo alemão, por exemplo, repousará principalmente sobre a idéia de que a estética caligarista trai a vocação objetiva do cinema ao submetê-lo ao registro do falso (o cinema, assim, perderia "sua extraordinária originalidade para se pôr na esteira das artes cuja matéria não é o mundo, mas a metáfora do mundo"61). Rohmer, nesse ponto, prefigura um dos aspectos capitais do pensamento de Mourlet. Em outra passagem de "Le cinéma, art de l'espace", contudo, ele chega à noção de "fascinação" justamente ao falar de expressionismo alemão (especialmente Murnau), enquanto Mourlet criará sua teoria da fascinação pelo caminho oposto, exaltando somente a transparência e a absorção diegética e rechaçando tudo que rimar com expressionismo.

Um dos pontos mais interessantes de "Le cinéma, art de l'espace" é a crítica feita por Rohmer ao espectador moderno, que habituou-se a interpretar o signo visual, mas se tornou deficitário em termos de percepção sensível; o filme, para esse espectador, é mais uma decifração que uma visão. "Ao aprender a compreender, o espectador moderno desaprendeu a ver" ${ }^{\prime 2}$. Essa crítica de Rohmer se deve ao fato de que para ele o essencial do cinema não está

61 Mourlet, "Sur un art ignoré", Cahiers du Cinéma nº 98, agosto de 1959.

62 Godard, a partir dos anos 1980 (ou talvez até antes), insistirá bastante sobre essa tecla. 
na linguagem. No plano da linguagem, caso nos atenhamos a ela, o cinema imitaria a retórica das outras artes. Ontologicamente, contudo, o cinema diz algo que as outras artes não dizem. Por isso não basta "ler" suas imagens.

O segundo texto de Rohmer a ser analisado é uma crítica de Stromboli escrita para a Gazette du Cinéma n $^{\circ} 5$ (novembro de 1950). Encantado pelo filme, ele diz que "a grandeza de Deus esguicha, não da boca daquele que a comenta, mas da presença mesma desse vulcão, dessa lava, dessas vagas, dessa praia italiana..." ${ }^{\text {63 }}$. Se quisermos compreender o estilo de Rossellini, deveremos antes perscrutar a fundo o material de que parte, porquanto é ao respeitar esse material que ele começa a encontrar sua mise en scène. A estética de Stromboli está primeiramente no espaço - na presença do espaço. Isso levará Rohmer a dizer que "a arte de Rossellini é uma das mais impróprias à expressão da vida interior”, como constatação de que a grandeza do mundo é, nesse filme, apresentada sem retórica, "somente pela evidência do que nos é dado a ver”; “cada coisa está presente, aparente, forma palpável, e o único paraalém que admite é a mão divina que presidiu sua gênese", ou seja, não é através de uma dialética ou de uma rivalização com a natureza que o intelecto humano conseguirá encontrar a graça e a beleza do mundo: o respeito à matéria implica o respeito à sua instância criadora. A mise en scène é um gesto de humildade diante do mistério da criação.

Se há, aqui, uma etapa de desenho (como Rivette apontara no processo de Rossellini), este desenho para Rohmer só pode ser o signo da presença de Deus nos homens e no mundo (e não custa mencionar que Disegno = segno di dio in $n o i^{64}$ ). No terceiro artigo de sua famosa série "Le celluloid et le marbre", ele dirá que o cenário das ruínas em Viagem à Itália está apenas presente, "mas essa presença é mais eloqüente que as mais belas sentenças antigas sobre a fragilidade do homem e a eternidade da natureza" ${ }^{65}$. Rossellini não cria uma nova aparência para o mundo, nem substitui sua matéria por uma outra; sua tarefa enquanto artista é, ao reproduzir as coisas, tentar entender o traço divino que lhes dá forma. Nessa série de artigos, Rohmer leva mais longe o cotejo entre o cinema e as outras artes:

[...] a arte mais positiva de todas, insensível ao que não é fato bruto, pura aparência, nos apresenta ao contrário a idéia de um universo hierarquizado, ordenado em vista de um fim último. Por trás daquilo que o filme nos dá a ver, não é a existência dos átomos o que somos conduzidos a buscar, mas antes a de um para-além dos fenômenos, de uma alma ou de todo outro princípio espiritual. (ROHMER, 1955)

63 ROHMER, Éric, Le goût de la beauté, Paris: Éditions de l'Étoile/Flammarion, 1989, p. 180.

64 Ver PANOFSKY, Erwin, Idea: a evolução do conceito do Belo, 2a ed. São Paulo: Martins Fontes, 2000.

65 "Le celluloid et le marbre - III: De la métaphore", Cahiers du Cinéma nº 51, outubro de 1955. 
O cinema vai das aparências aleatórias, onde reside não só sua matéria-prima como também seu ponto de partida, para a obra enformada segundo idéias e metas. Assim sendo, inverte o processo criativo em comparação às artes precedentes:

Ao contrário das outras artes que vão do abstrato ao concreto e, fazendo dessa busca do concreto sua meta, nos escondem que seu fim último não é imitar mas significar, o cinema nos lança aos olhos um todo do qual será prazeroso destacar uma das múltiplas significações possíveis. É da aparência mesma que devemos extrair esse sentido, e não de um além imaginário do qual ela seria apenas o signo. O real é aqui matéria privilegiada pois ele tira sua necessidade da contingência mesma de sua aparição. $\mathrm{O}$ documento acede à dignidade de arte. Os sentimentos são captados enquanto movimentos. Não é mais a paixão, mas o trabalho, ou seja, a ação do homem, o que o cinema se deu por tema. (ROHMER, 1951)

No trecho acima, é como se Rohmer recolocasse a definição de Panofsky do cinema como a arte materialista por excelência: “Os processos de todas as artes representacionais primitivas aderem em grau maior ou menor a uma concepção idealística do mundo. Elas operam de cima para baixo, por assim dizer, e não ao contrário. Começam com uma idéia a ser projetada na matéria amorfa e não com os objetos que constituem o mundo físico. [...] É o cinema, e tão somente o cinema, que faz justiça a essa interpretação materialista do universo" $" 66$.

É o mundo físico, captado por esse olhar "insensível ao que não é fato bruto", que constituirá o material primeiro de cineastas como Rossellini e Hawks. O sentido e a finalidade do filme só podem ser prospectados tendo em vista a "magnificência desse mundo sensível que somente o cinema tem o privilégio de oferecer intacto aos nossos olhos" ${ }^{\prime 67}$ :

\begin{abstract}
A tarefa da arte não é nos encarcerar num mundo fechado. Nascida das coisas, ela nos reconduz às coisas. Ela se propõe menos a purificar, ou seja, a extrair delas o que se dobra a nossos cânones, do que a nos reabilitar e conduzir sem cessar a reformar esses cânones. (ROHMER, 1951)
\end{abstract}

A arte, portanto, deve reconduzir as coisas da natureza a seu estado original, mais do que sujeitá-las a uma lei humana. Recebendo as informações provenientes da experiência sensível, o artista se reconcilia com o mundo ao deixar que este lhe imponha uma lei natural. É aí que reside a sabedoria do classicismo: artistas que não querem fazer mais do que lhes

66 Panofsky, "Estilo e meio no filme", em LIMA, Luiz Costa (org.), Teoria da cultura de massa, Rio de Janeiro: Saga, 1969.

67 Rohmer, "Vanité que la peinture". 
permite a matéria. Os períodos clássicos, segundo Rohmer, foram aqueles em que "beleza segundo a arte e beleza segundo a natureza pareciam ser a mesma coisa". Tal arte nasceria de uma "irresistível vontade de olhar o mundo com os olhos nossos de todos os dias, de conservar as coisas tais como são, a despeito de nós":

\begin{abstract}
Eu gostaria de dissipar um sofismo. Onde não há intervenção do homem, diz-se, não há arte. Ora, mas é sobre o objeto pintado que o amante de arte porta primeiro seu olhar e se ele considera a obra e o criador, é apenas por reflexão segunda. Assim a meta primeira da arte é reproduzir, não o objeto sem dúvida, mas sua beleza; o que chamamos de realismo não é senão uma busca mais escrupulosa dessa beleza. A crítica moderna nos habituou, ao contrário, a essa idéia de que nós só gostaríamos nas coisas daquilo que é pretexto à obra de arte: se o artista dirige nossa atenção sobre objetos que o senso comum julga ainda indignos, é que haveria aqui mais a fazer para nos seduzir. A beleza de um cais ou de um terreno vago nasceria do ângulo sob o qual ele nos força a descobri-los. Acontece que essa beleza não é outra que não aquela do terreno vago e que a obra mesma é bela não porque ela nos revela que podemos fazer o belo com o informe, mas porque o que julgamos informe é belo. Chego então nesse paradoxo que um meio de reprodução mecânico como a fotografia é em geral excluído da arte, não porque ele só sabe reproduzir, mas precisamente porque ele desfigura mais ainda que o lápis ou o pincel. O que sobra de um rosto sobre a instantaneidade de um álbum de família, senão uma insólita careta que não é ele? Fixando o móvel, a película trai justo à semelhança mesma. (ROHMER, 1951)
\end{abstract}

O cinema, para realizar todas as suas possibilidades e se tornar digno de uma era clássica, precisa estar apto a reconhecer a beleza intrínseca das coisas. Uma vez tendo aprendido que, para exercer toda sua potência estética, não necessita deformar o objeto, mas justamente preservá-lo em sua natureza mesma, o cinema encontra sua finalidade na história das artes. "O que um cineasta digno desse nome pretende nos fazer partilhar não é sua admiração pelos museus, mas a fascinação que exercem sobre ele as coisas mesmas." $O$ cinema, na ótica de Rohmer, teria desfeito um engano histórico, que creditava a arte à intervenção humana, e teria provado que o grande mérito de um artista pode consistir na busca de uma beleza que já se encontra no mundo, sem precisar inventá-la da própria cabeça. Essa beleza inclui o movimento, ou melhor, a mobilidade do mundo, seu ser-movente, de cuja ausência a fotografia se ressente a ponto de tornar-se uma desfiguração do real ainda maior que a pintura $^{68}$. Haveria para Rohmer uma poesia imanente do cinema que dispensaria o

68 A diferença entre o cinema e a pintura, para Rohmer, é na verdade apenas de grau: "o pintor também já tinha um respeito pelo real, à sua maneira" ("Le celluloid et le marbre - II: Les siècles des peintres", Cahiers du Cinéma $\mathrm{n}^{\mathrm{o}} 49$, julho de 1955). 
realizador de recorrer ao símbolo, sobretudo o símbolo "pesadamente explicitado": "A beleza de uma onda captada em cores pela tela grande torna, mais que nunca, supérfluo todo artifício de estilo"69. O maior privilégio do autor é tornar sensível a interferência entre o mundo material e o do espírito sem o menor recurso aparente ao símbolo, à elipse, à alusão. "Ele [o cinema] nos descobre de novo sensíveis ao esplendor do mar e do céu, à imagem mais banal dos grandes sentimentos humanos. Miraculosamente ele sela o acordo da forma e da idéia e banha nossos olhos ainda novos da igual e pura luz do classicismo". O elogio de Rohmer ao classicismo destaca a luz que se propaga em linha reta, o olhar sem filtro, sem maneiramento, sem fermento de estilo, atido ao essencial. Quanto ao realismo de Rossellini, este nada mais seria que a "busca escrupulosa" de uma beleza já presente no mundo dos corpos, já impressa nas faces das coisas, ainda que sua aparição se limite a instantes fugidios (eis uma semente de teoria para as "epifanias" rossellinianas) - daí a necessidade de uma atenção redobrada, de uma meditação cuidadosa.

Um outro tipo de beleza pode ser encontrado em Hitchcock, cujo cinema Rohmer define como a arte de sondar o interior das almas e exprimir, pelo visível, o indizível dos sentimentos. Grande admirador de Hitchcock, Rohmer enxerga nele a busca de uma estilização nem sempre a serviço de uma concepção muito rigorosa das relações do conteúdo e da expressão (essa espécie de desperdício de estilo será o combustível principal das injúrias de Mourlet a Hitchcock). Na sua crítica de Um Corpo que Cai, Rohmer conclui que os filmes de Hitchcock têm por objeto as Idéias, "no sentido nobre, platônico do termo"70, cabendo-lhe interrogar em que condições é possível ao cineasta conhecer e ver essa beleza supra-terrestre e supra-real. A beleza, agora, não é necessariamente a revelação da coisa em si, mas a beleza de uma arquitetura mental que perpassa a obra em todo seu relevo. É garantida à Idéia uma prioridade genética e sistemática no processo de compleição do filme.

Falamos muito em "beleza" nos últimos parágrafos. E não foi por mero acaso: a "beleza" é a expressão que Rohmer elege como índice supremo daquilo que lhe causa fascinação no cinema. No artigo "Le goût de la beauté" (originalmente em Cahiers du Cinéma $\mathrm{n}^{\mathrm{o}} 121$, julho de 1961), que seria o título da antologia de textos críticos de Rohmer mais tarde publicada, ele expõe argumentos de uma autêntica teoria do belo no cinema e chega a dizer que:

A Beleza - ou belezas - é um conceito preferível ao da mise en scène, também aqui preconizado, mas que não quero, porém,

\footnotetext{
69 Rohmer, "Le celluloid et le marbre - III: De la métaphore" (Cahiers du Cinéma no 51, outubro de 1955).
}

70 "L'Hélice et l'Idée", Cahiers du Cinéma no 93, março de 1959. 
denunciar. A primeira noção inclui a segunda, a qual, por sua vez, possui também uma acepção técnica. (ROHMER, 1961)

A mise en scène, para a qual contribuem técnicas que são instrumentos de reprodução ou de conhecimento, apresenta-se então como uma das dimensões da beleza, e esta, por sua vez, não nasce de um truque de escritura, mas de uma visão que é a compreensão mesma das coisas. Rohmer propõe a inversão do axioma "nada é belo a não ser o verdadeiro" para "nada é verdadeiro a não ser o belo", à guisa de melhor compreender o "cinema em si" amado nos Cahiers e lhe abrir perspectivas mais justas. O cinema "possui a verdade de partida, e se propõe a beleza como fim supremo. [...] Uma beleza que tem por função não inventar, mas descobrir, capturar como uma presa, quase despir as coisas". Ele repete aqui um argumento que dez anos antes já estava em "Vanité que la peinture": o da beleza imanente ao olhar cotidiano, ao mundo de todos os dias, às coisas que se oferecem à representação não porque foram preparadas para o olhar do artista, mas porque estão onde o tempo as colocou. Um movimento comum, uma coisa vista onde sempre esteve, de repente suscita um desenho na mente do $\operatorname{artista}^{71}$. O olhar preconizado por Rohmer não é o do deslumbramento nem o da contemplação hipnótica, mas um olhar que se direciona a coisas que não precisam de validade, só de presença. A mise en scène, em ultima análise, seria o poder de copiar a beleza natural. Se por um lado o cinema não fabrica essa beleza, por outro ele a suscita.

O panorama acima está longe de esgotar o pensamento de Rohmer e Rivette. No caso de Rohmer, por exemplo, teríamos de levar em consideração a importância que ele atribuiu à obra de Jean Renoir, sobre a qual escreveu no mínimo dois textos fundamentais: "Renoir américain" (Cahiers du Cinéma no 8, janeiro de 1952) e "Jeunesse de Jean Renoir" (Cahiers du Cinéma $\mathrm{n}^{\mathrm{o}} 102$, dezembro de 1959). No caso de Rivette, devemos lembrar também a admiração que ele tinha por cineastas como Preminger, Astruc, Ophüls ou Mizoguchi. Para ele, esses cineastas definem uma nova noção de cinema "puro" em que o objeto, "longe de ser destruído, revela e superpõe todos os seus rostos”. Rossellini, todavia, permanecerá seu modelo mor: "Levando nossa arte ao ponto em que Picasso levou a pintura, essa idéia do cinema moderno é também um absoluto, ao qual tudo pode ser sacrificado. Eis aliás o perigo; eis porque, por maiores que sejam esses cineastas, somente Rossellini permanece exemplar, ele que, possuindo também esse segredo, ousa ainda sacrificá-lo por outra coisa, e presta

${ }_{71}$ Cf. VALÉRY, Paul, Introdução ao Método de Leonardo Da Vinci, São Paulo: Ed. 34, 1998. 
serviço àquele que mantém alhures seu poder de tudo submeter a suas metamorfoses" (“Sainte Cécile”, Cahiers du Cinéma, no 82, abril de 1958). Em outras palavras, Rossellini é o único - e Rohmer provavelmente concordaria - apto a abdicar de todo e qualquer estilo em nome da captura, a partir da realidade imediata, de algo a que Mourlet muito justamente chamará uma "respiração do divino" 72 .

Embora haja pontos de contato nos textos de Rivette e Rohmer, assim como nas suas preferências cinéfilas (Rossellini, Hawks, Lang, Renoir), não podemos deixar de sublinhar as suas diferenças, que se tornam mais pronunciadas depois de 1960. Há uma divergência de pensamento, quiçá "uma estranha esquizofrenia rohmero-rivettiana" no seio dos Cahiers: Rohmer, redator-chefe no período 1957-1963, passa por defensor do cinema clássico e do classicismo hollywoodiano, enquanto Rivette, que lhe sucede na função, se torna o defensor da modernidade, preparando a via para os novos cinemas (Europa, Japão, Brasil) e abrindo a revista às ciências humanas (entrevistas com Roland Barthes, Pierre Boulez, Claude LéviStrauss). "Não reconciliados, Rohmer e Rivette? Em virtude de seu cinema, de sua sensibilidade política (Rohmer à direita, Rivette mais à esquerda), ou porque um belo dia houve um golpe de estado e Rivette tomou o lugar de Rohmer enquanto redator-chefe?"73.

Não se pode levar tão ao pé da letra a idéia de que havia uma oposição Rohmer/classicismo-Rivette/modernidade. Rohmer volta e meia desfrutou momentos mais modernos que Rivette e este muitas vezes se mostrou mais clássico que o primeiro. Mas a despeito das diferenças, o mais importante é que ambos, Rohmer e Rivette, deixaram um legado na história dos Cahiers du Cinéma que sem dúvida alguma persiste até hoje.

\section{Michel Mourlet e o mac-mahonismo}

Em agosto de 1959, os Cahiers du Cinéma publicam o antológico artigo de Michel Mourlet, "Sobre uma arte ignorada" ("Sur un art ignoré"). Publicam o texto inteiro em itálico, para marcar uma certa estrangeirice daquelas idéias (ou seja, era um texto ao mesmo tempo de dentro e de fora dos Cahiers), e com um parágrafo de introdução (escrito, acredita-se, por Rohmer ou por Rivette - ou pelos dois) sugerindo uma afinidade - ainda que não integral com o artigo e alertando para seu conteúdo "extremista"74. Como Aumont bem definiu, o

72 "Les cerisiers sont merveilleux - quatre films d'Ozu", La mise en scène comme langage, Paris: Ramsay, Poche Cinéma, 2008.

73 Charles Tesson, "Peut-on être rohmero-rivettien?", p. 8.

74 Eis a introdução que lá consta: "Ainda que a linha de conduta dos Cahiers seja menos rigorosa do que por vezes se pensa, este texto só dela se afasta evidentemente em alguns pontos. No entanto, sendo de respeitar 
texto consiste em "um dos manifestos artísticos mais diretos alguma vez escritos sobre o cinema”. Mourlet expõe uma concepção de mise en scène que, em grande parte, já fora trabalhada por Rivette e Rohmer. Em seu pensamento, contudo, a definição se torna mais essencialista, mais ciosa de métodos, mais atida ao que, segundo ele, seria a medula do cinema.

No primeiro dos nove segmentos de "Sobre uma arte ignorada", Mourlet se apressa em explicar sua noção de "essência" do cinema (não sem antes problematizá-la brevemente). A essência desta arte, para ele, está diretamente vinculada àquela propriedade de apreensão imediata do real a que Rohmer já havia dado bastante ênfase. "O princípio do cinema como modo de apreensão é fundado sobre o registro passivo das deformações do espaço", diz Mourlet. No trecho abaixo, ele ecoa o Rohmer de "Vanité que la peinture":

\begin{abstract}
A arte sempre havia sido uma mise en scène do mundo, ou seja, uma chance dada à realidade contingente e inacabada de se locupletar, de um golpe preciso, segundo os desejos do homem. Mas esse mundo não podia ser apreendido senão por um meio termo, era preciso recriá-lo em uma matéria indireta, transpô-lo, proceder por alusões e convenções, na impossibilidade de uma possessão imediata. [...] Nessas condições, a obra se media em valor absoluto independentemente de sua técnica, a renovação desta não engendrando um progresso, mas a simples exploração de um domínio novo. [...] Ora, no fim do século XIX, um evento considerável vem bagunçar esses dados. O meio de captar a realidade diretamente, sem mediação, sem essas convenções cuja necessidade Valéry tinha compreendido muito bem quando se trata de recriar pelas forças do homem, fora descoberto. Um olho de vidro e uma memória de bromato de prata deram ao artista a possibilidade de recriar o mundo a partir daquilo que ele é, portanto de fornecer à beleza as armas mais agudas do verdadeiro. (MOURLET, "Sur un art ignoré", 1959)
\end{abstract}

A partir da primeira frase do longo trecho de "Sobre uma arte ignorada" citado acima, cumpre indagar se a mise en scène será então a linguagem criada pelo homem para, através da arte, fundar para si mesmo um reino no interior da natureza, sem todavia almejar sobrepujá-la ou negar sua primordialidade. Será a mise en scène a união - tida por Goethe como a atitude mais elevada do artista - entre a experiência concreta e o conhecimento objetivo do mundo, entre o sensível e o inteligível do homem? É cedo ainda para chegar a tais conclusões. Mas tenhamos em mente essa pergunta.

Mourlet retoma, em certa medida, a saga baziniana em que Rohmer já tinha se aventurado na série "Le celluloid et le marbre". O mote principal dessa aventura é a 
convicção de que o cinema inverte o caminho das outras artes, que iam do abstrato ao concreto, e tem diante dele o mundo - não uma idéia de mundo, mas o mundo em si. Nas artes anteriores ao cinema, segundo Mourlet, "o mundo cambiava sua forma contra sua verdade", e a substância do artista não era o mundo, mas sua recriação por meio de outros materiais: ao fabricar sua própria matéria, a arte se afirmava enquanto tal na justa medida em que dava provas de uma representação sem conexão ontológica com o mundo. Só o cinema permitirá ao artista "recriar o mundo a partir daquilo que ele é", e portanto tornará o belo sinônimo de verdadeiro, conforme Jacques Serguine depois salientará à exaustão em "Educação do espectador"75 e Rohmer repetirá em "Le goût de la beauté".

Também no primeiro segmento de "Sobre uma arte ignorada", não à toa intitulado "O cinema começa com o sonoro", Mourlet retoma uma antiga discussão (àquela altura, já abandonada pela maioria dos críticos) sobre a transição do cinema silencioso para o sonoro. Ele adere à visão evolucionista de Bazin e qualifica a chegada do som como uma etapa natural no processo de amadurecimento do cinema. O som não apenas seria "uma implicação necessária das premissas visuais do cinema", como também "a linguagem metafórica das imagens mudas" corresponderia "à obrigação de falar na ausência do som, e não a uma finalidade interna". A proliferação, na era muda, de metáforas visuais, recursos de montagem exclamativos, grafismos, trucagens etc. nada significa, para Mourlet, além de uma "deformação das aparências" que "traía a vocação original da câmera". Expressionismo alemão, surrealismo e vanguardas dos anos 1920 não passariam do "último sobressalto de uma estética minada por sua contradição interna”. Serguine dirá quase a mesma coisa: "Houve um tempo em que [o olhar da câmera] traía o silêncio mesmo, não podendo apreender essas grandes fontes de harmonias e de conflitos que são as cores do mundo. Então, ele brutalizava o preto e o branco, para suplantar sua enfermidade”. O expressionismo evocado por Serguine seria, portanto, uma arte enferma, que compensaria sua deficiência pela inflação de uma outra função. O cinema silencioso, está claro para ambos, é uma arte incompleta, e nisso reside a explicação dialética de todos os seus excessos.

$\mathrm{O}$ argumento de Mourlet para justificar a teoria evolucionista do cinema repousa sobre aquele fato que discutimos lá no início deste trabalho: no cinema, a técnica não é apenas instrumento ou meio auxiliar, mas elemento estruturante. "Assim, uma arte cuja singularidade é estar fundada sobre a técnica no sentido mecânico da palavra se acha, por esse fato,

75 “O único belo é o verdadeiro, só se pode amar o verdadeiro. [...] Descobrimos a grande regra: só deve existir na tela aquilo que pode existir no mundo dos homens; quero dizer, sem temer de novo os mal-entendidos, no mundo de todos os dias. [...] Falei de alma, excessivamente, de nudez, de beleza, de verdade. É que, para mim, essas palavras são praticamente sinônimas. Pode-se partir do corpo, ou chegar nele; desde que se vá tão longe, chega-se à verdade, e para mim, a verdade do homem é bela." 
suscetível de progresso, noção incompatível com a concepção tradicional da arte”. O progresso da técnica, inexorável, determinaria automaticamente o que Bazin chamou de "evolução da linguagem cinematográfica". O cinema mudo, nessa perspectiva, não é um paraíso perdido de "perfeição primitiva" que o som viria aniquilar (como houve quem dissesse na época da passagem mudo-sonoro), mas justamente o contrário: uma arte que, à espera de uma técnica que lhe permita afinar-se melhor aos sentidos humanos, dá sinais de “inacabamento e mal-estar". O som seria a decorrência natural de uma arte que deveria aproximar-se cada vez mais da percepção natural, rumo ao "cinema total" cujo mito fora cantado por Bazin. "É preciso ousar dizer que o cinema começa com o sonoro", diz Mourlet: "Aquilo a que costumamos chamar as obras-primas do mudo são apenas as etapas de um desabrochamento".

Mourlet vê primitivismo e incompletude lá onde muitos enxergaram modernidade e vanguarda $^{76}$. Ele encara o cinema mudo mais ou menos como Hegel encarava a arte egípcia: uma deformação simbólica que seria corrigida pela arte retilínea dos gregos ${ }^{77}$. A crítica de Mourlet ao cinema mudo, sua afirmação de que a própria natureza imediata do registro cinematográfico deflagraria a contradição interna de um cinema (o cinema da sobrecarga expressionista, das hipérboles surrealistas, dos experimentalismos etc) que se esforçava na direção oposta à apreensão direta do real, assemelha-se à crítica de Hegel às artes préclássicas: a defeituosa exterioridade da significação, enquanto conteúdo essencial, e da forma definida de sua representação, se afirmaria com mais força ainda na arte analógica, na qual os dois lados, significação e representação, se revelam completamente independentes um do outro e não estão aproximados senão pela invisível subjetividade analogizante. Segundo essa noção hegeliana, quanto mais analógica uma arte pré-clássica se mostra, mais ela acusa sua defasagem entre significação e representação, e portanto mais acentuada é sua desfiguração do mundo. Tal noção parece orientar o argumento de Mourlet de que "toda deformação da realidade com fins de expressão, condição das artes tradicionais, pelo fato de que ela chega ao espectador de cinema através da objetividade da câmera, se revela como mentira". Para Mourlet, o caráter objetivo do "olhar impassível" da câmera dá ao cinema seu próprio detector de mentiras: se tomado "por um simples jogo de imagens suscetível de todas as combinações possíveis", esquecendo-se que o ponto de partida dessas imagens é "um olhar sobre o mundo sensível", o cinema demonstra, em contragolpe, que não se pode trapacear com a câmera, e "o imenso poder de credibilidade da fotografia se volta contra si mesmo para

\footnotetext{
76 Rohmer tem uma visão parecida com a de Mourlet sobre o assunto. Ver "Pour un cinéma parlant", em Le goût de la beauté, pp. 46-52.

77 Hegel, L'art classique, Paris: Aubier-Montaigne, 1964.
} 
denunciar a inverossimilhança, multiplicado pela aparência do verdadeiro. O que poderia ser poesia nas palavras, porque a linguagem está apta a refletir as combinações ilimitadas do espírito, é apenas trucagem nos limites do olhar”. Aí já se entrevê que a figura do cineasta moderno (pós-Welles) como equivalente do romancista, municiado de uma "caméra-stylo", não agradará Mourlet.

Ao aproximar a visão de Mourlet da hegeliana, não se pode negligenciar uma diferença fundamental de paradigmas: Hegel, ao falar da transição das artes egípcia e grega, discorre sobre "duas eras da humanidade, duas concepções do mundo se exprimindo através de meios invariáveis", enquanto Mourlet, avaliando a transição do cinema mudo para o sonoro, encara "o mesmo homem, antes paralisado, mudo, atingindo perturbações visuais, depois em possessão de todas as suas faculdades". Na arte antiga, tratam-se de duas civilizações diferentes que, em posse dos mesmos materiais, chegam a duas expressões artísticas também diferentes (a evolução, portanto, começa fora do domínio específico da arte); no cinema, trata-se de uma mesma civilização que, em contato com uma arte cujos materiais e cuja técnica se modificam substancialmente num dado momento, assiste a uma revolução no seio dessa arte que, antes limitada, agora se torna mais robusta (a evolução, aqui, começa no interior mesmo da matéria específica do cinema).

Passemos ao segundo segmento de "Sobre uma arte ignorada", que Mourlet designa por meio da frase que dá título à primeira parte deste trabalho: "Tudo está na mise en scène". É um segmento pequeno, consistindo apenas em um parágrafo, que reproduzo na íntegra:

A cortina se abre. A noite se faz na sala. Um retângulo de luz vibra em sua presença diante de nós, e é logo invadido por gestos e sons. Nós estamos absorvidos por esse espaço e esse tempo irreais. Mais ou menos absorvidos. A energia misteriosa que suporta com alegrias diversas (bonheurs divers) a enxurrada de sombra e de claridade e sua espuma de ruídos se chama mise en scène. É sobre ela que repousa nossa atenção, ela que organiza um universo, que cobre uma tela; ela, e nenhuma outra. Como a correnteza das notas de uma peça musical. Como o escoamento das palavras de um poema. Como os acordos ou dissonâncias de cores de um quadro. A partir de um assunto, de uma história, de "temas", e mesmo do último tratamento do roteiro, como a partir de um pretexto ou de um trampolim, eis o jorramento de um mundo do qual o mínimo que podemos exigir é que ele não torne vão o esforço que o fez nascer. A mise en place dos atores e dos objetos, seus deslocamentos no interior do quadro devem tudo exprimir, conforme vemos na perfeição suprema dos dois últimos filmes de Fritz Lang, O Tigre de Bengala e Sepulcro Indiano. (MOURLET, "Sur un art ignoré, 1959)

A mise en scène é aí definida como um mistério, logo é sobre ela que repousa a 
atenção do espectador, é ela que "organiza um universo". Tomando como parti pris um roteiro ou mesmo um pretexto qualquer, a mise en scène é a fonte de energia do filme, a semente gravitacional que atrai matéria para perto de si e dá origem ao cosmo. O metteur en scène é aquele capaz de compreender esse brotamento cósmico, essa ordem que está por trás do "jorramento de um mundo". A resposta do espectador, por sua vez, é a fascinação: ele está lá, absorvido por "esse espaço e esse tempo irreais". E isso se deve à mise en scène, pois é ela que cria o mundo da ficção, o volume da diegese, a materialidade do espaço, é ela que dispõe as figuras no quadro, relaciona a luz aos cenários e aos figurinos, dá movimento aos corpos, e é dela que o espectador lembra ao sair de um filme (pode ser uma roupa, uma atmosfera, um gesto.... $)^{78}$.

Mourlet localiza a "perfeição suprema" da mise en scène - arte da mise en place e dos deslocamentos, relação espacial entre as figuras do drama e as arquiteturas dos cenários - no dístico indiano de Fritz Lang, cineasta sobre o qual escreverá um texto na edição seguinte dos Cahiers em que levará adiante sua teoria da fascinação:

\begin{abstract}
Que pode ser um filme, senão um necessário e implacável escoamento de imagens em que a consciência fascinada se apaga, se esquece, para se reencontrar no mais íntimo do ser? [...] Trata-se, como em toda obra de arte, de impor uma certa forma do mundo com o máximo de intensidade, de maneira a paralisar o reflexo crítico pela evidência da revelação. [...] A eliminação do acaso, a dominação constante das formas por uma arquitetura onde todas as partes se respondem e se provocam, atingirão uma fascinação, ou impossibilidade para o espectador de se arrancar à ordem do espetáculo. (MOURLET, “Trajectoire de Fritz Lang”, 1959)
\end{abstract}

Nos filmes de Fritz Lang, a consciência espectatorial se torna receptáculo passivo de uma espécie de liturgia. As imagens criam um mundo tão coeso, e se encontram articuladas numa arquitetura de tamanha beleza, que o reflexo crítico é paralisado pela "evidência da revelação"; o espectador se vê impossibilitado de escapar à sua absorção diegética pelo espetáculo:

A absorção da consciência pelo espetáculo se nomeia fascinação:

78 Ver BORDWELL, David e THOMPSON, Kristin, Film Art: An Introduction / Second edition, Nova Iorque: Alfred A. Knopf, 1986. Embora a abordagem de Bordwell e Thompson seja essencialmente diferente, eles também identificam a mise en scène ao mundo criado pelo filme - a diferença é que eles atribuem isso a uma técnica, e não a um mistério. A mise en scène, que eles dividem em cinco aspectos principais (Setting, Costume and Make-up, Lighting, Figure Expression, Movement), seria o grande elemento adesivo entre o filme e o espectador: "De todas as técnicas do cinema, a mise-en-scène é aquela com que estamos mais familiarizados. Depois de ver um filme, podemos não lembrar da montagem ou dos movimentos de câmera, das fusões ou do som fora-de-tela, mas vamos quase certamente lembrar de itens da mise-en-scène. [...] Ao controlar a mise-en-scène, o diretor encena o evento para a câmera." (p. 119) 
impossibilidade de se arrancar das imagens, movimento imperceptível rumo à tela de todo o ser tencionado, abolição de si nas maravilhas de um universo onde até mesmo morrer se situa no extremo do desejo. Provocar essa tensão rumo à tela aparece como o projeto fundamental do cineasta. Em decorrência, o movimento, domínio específico de nossa arte, deve se adensar de um jogo ou se encher de uma graça tais que ele impeça a irrupção da consciência crítica no encadeamento dos atos filmados. [...] Assim, em certas circunstâncias excepcionais da vida, ficamos fora de nós mesmos, como estrangeiros a nossa ação, inteiramente requisitados pelo exterior. (MOURLET, "Sur un art ignoré”, 1959)

Ao enaltecer essa consciência preenchida pelo espetáculo, apaziguada em suas contradições, dissolvida na ficção, extasiada, Mourlet evidentemente está se colocando nos antípodas do distanciamento brechtiano, que para ele "arruína o poder do espetáculo para restaurar o vazio no coração do espectador". O sentido do drama, para Mourlet, deve ser o que está expresso na seguinte passagem de "Sobre uma arte ignorada":

\begin{abstract}
Apertado por um nó de angústia e de exaltação, o ser é revelado a si mesmo, projetado fora de si rumo a um eu mais autêntico cuja paixão o preenche e o justifica, o seqüestra em uma vertigem onde ele se reconquista em sua totalidade. A contradição levada a seu ponto extremo se resolve em sua tomada de consciência e sua contemplação, que a alça ao sagrado de uma necessidade, portanto de um aquiescimento, de um equilíbrio, de uma paz. É toda a vocação do trágico na arte. $\mathrm{O}$ afrontamento, a "crise" visa a uma torção do ser sobre si mesmo, onde tendo sido percorrido o círculo completo, o ser se reencontra no início em sua nudez luminosa e apaziguada. (MOURLET, "Sur un art ignoré”, 1959)
\end{abstract}

O que ele descreve na passagem acima é o disciplinamento dos impulsos subjetivos conforme posto em prática, por exemplo, nas tragédias de Racine (referência importantíssima para Mourlet): paixões veementes e dissonâncias barrocas (a idéia de uma "torção do ser sobre si mesmo") domadas por uma forma clássica. Ao falar do drama como "afrontamento" que permite ao ser "se reencontrar no início em sua nudez luminosa e apaziguadora", ele comenta o efeito moral da arte conhecido desde o elogio da tragédia em Aristóteles: enobrecer o homem, purgando-o da carga de paixões que ele acumula na vida social e não consegue descarregar. Obras criadas "para o prazer e o ensinamento dos homens", algo que no classicismo corresponde à "vontade de fazer a obra atingir o ponto de reconciliação de seus termos fragmentados: o homem, o mundo"79.

Os grandes artistas, na acepção de Mourlet, "propõem do homem uma imagem

79 Cf. "Joseph Losey face ao público", em Contracampo no 92

(http://www.contracampo.com.br/92/artloseymourlet2.htm). 
incandescente que nos projeta para fora de nossa banalidade cotidiana, em um universo onde a alma se dilata, se rasga e ganha a medida de seus possíveis”. A arte, para Mourlet, não é "um reflexo passivo da realidade integral", uma vez que nasce precisamente da "necessidade de reformá-la, de se reconciliar com ela". Que o cinema seja uma apreensão a mais concreta possível do real não significa que ele deva abdicar de ordená-lo, ou de buscar nele o elemento extraordinário. Se, por um lado, o cinema não deve abraçar "a mentira, a trucagem e os artifícios de estetas", por outro não deve também se limitar "a restituir as aparências incontroladas"; ele precisa ser, ao mesmo tempo, "o documentário e a feeria, tratando-se da beleza imposta pela evidência do olho irrecusável". Ele não deve estagnar na contemplação de uma realidade assignificante e opaca, mas sim encontrar nela a força do desvelamento e da emoção. Ao se ater à superfície dos fenômenos, o cinema - por um duplo movimento de restituição e descortinamento da epiderme do real - fixa os supremos momentos desses fenômenos superficiais, na medida em que consegue reconhecer neles "o ápice da beleza, a dignidade do significado, a altura da paixão" 80 . Como diz Paul Valéry, o artista (ou o "homem universal") começa por contemplar simplesmente, mas logo se impregna de espetáculos, retorna à emoção produzida pela menor coisa real ${ }^{81}$.

Numa nota de rodapé de "Sobre uma arte ignorada", Mourlet afirma: "O cinema cristaliza e realiza toda a vontade de verdade difusa nas outras artes, ele é, nesse sentido, seu epítome. Mas ele se torna sua derrisão caso estacione nesse degrau e fabrique, por exemplo, 'reportagem vivida'...". Daí toda a recusa de Mourlet em relação ao neo-realismo, que ele considera um projeto contraditório: um cinema que quer oferecer "o que a rua nos oferece com o mérito de ser real", portanto um cinema sem propósito ou razão de ser. O modo de encarar a realidade no cinema, segundo Mourlet, não pode se calcar "nem em sua proliferação casual e banal, nem em um direcionamento rumo ao impossível ou ao falso", mas numa "seleção das aparências" que vise o equilíbrio entre o cotidiano e o excepcional:

\footnotetext{
Porquanto o cinema é um olhar e um ouvido mediadores entre o espectador e as aparências, porquanto a organização das aparências e sua apreensão mais eficaz constituem a mise en scène, como esta será em si beleza, isto é, exorcismo de malefícios e canto? A resposta é: pela seleção das aparências, a narrativa sobre um retângulo branco de certos movimentos privilegiados do universo. Dito de outro modo, sobretudo naquilo que elas têm de mais íntimo, as ações e reações de um homem em um cenário. [...] $\mathrm{O}$ ponto de chegada do cinema, atingido em raros instantes pelos grandes dentre os grandes - Losey, Lang, Preminger e Cottafavi -, consiste em
}

80 Goethe, "O ensaio sobre a pintura de Diderot (1798)", in Escritos sobre a arte, São Paulo: Humanitas/Imprensa Oficial, 2008, p. 151.

81 Ver Introdução ao Método de Leonardo Da Vinci, São Paulo: Ed. 34, 1998. 
despir o espectador de toda distância consciente para precipitá-lo em um estado de hipnose mantido por um encantamento de gestos, de olhares, de ínfimos movimentos do rosto e do corpo, de inflexões vocais, no seio de um universo de objetos radiantes, injuriantes ou benéficos, onde alguém se perde para se reencontrar engrandecido, lúcido e apaziguado. (MOURLET, "Sur un art ignoré”, 1959)

A mise en scène não é o suporte privilegiado de operações excessivamente intelectuais, não se presta à retórica ou às práticas puramente discursivas. Ela diz respeito às ações e reações de um ator em um cenário - Rivette já havia dito algo muito próximo disso em "Génie de Howard Hawks", texto em que a idéia de fascinação passava por descrições semelhantes a esse "encantamento de gestos, de olhares", a essas ações corpóreas que, ao provocar reações do espaço, engendram uma "seleção das aparências" correspondente à narrativa de "certos movimentos privilegiados do universo". Na evidência desses movimentos, porquanto eles representam a "organização das aparências e sua seleção mais eficaz", reside a mise en scène. Mas Mourlet não vê isso em Hawks, e sim na lista de quatro cineastas que ele coloca como os "grandes dentre os grandes": Losey, Lang, Preminger, Cottafavi (este último seria mais tarde substituído por Walsh na já citada "quadra de ases" dos mac-mahonistas). Na mais eficaz seleção das aparências, de que esses quatro cineastas são capazes, Mourlet vê algo como "a força de reconhecer na extensão do mundo uma quantidade extraordinária de coisas distintas e de arranjá-las de mil maneiras" (Valéry).

As mil maneiras desse arranjo, contudo, não podem perder de vista uma regra essencial: a transparência. Mourlet tem verdadeira ojeriza aos procedimentos de montagem intelectual ou de atrações, que rompem a lógica dramática da cena para impor "a intervenção exterior e brutal de uma vontade que se superpõe ao olhar da câmera e este, de transparente, puramente mediador que deveria ser, se opacifica, se embaralha, até restabelecer entre o espectador e o espetáculo a distância que se propunha a abolir". A montagem com fins expressivos trai a fascinação, e portanto frustra a maior meta do cinema. A montagem deve consistir em "tornar os cortes efetuados na massa informe do real tão invisíveis quanto possível":

A única montagem (ou decupagem, se consideramos a operação em sua origem) adequada ao modo de apreensão cinematográfica da realidade é aquela que adere, justo à identidade completa, ao desenvolvimento de uma série dramática dada, por seleção e justaposição de planos essenciais, como um olhar que iria sempre direto ao que importa na marcha de um evento. Assim, o espectador não é posto em face de vários espetáculos ao mesmo tempo, ou de uma análise do espetáculo por um olho absurdo que transgride as 
leis da atenção, situações que o distanciam brutalmente do espetáculo ao defini-lo por contradição com este último; ele está diante do espetáculo, diante do mundo, o mais próximo do mundo, graças à docilidade, à ductilidade de um olhar que o seu desposa de tal modo que o esquece. (MOURLET, "Sur un art ignoré", 1959)

As noções de cenicidade (um respeito à integridade dramática e espaço-temporal da cena, em oposição à sua fragmentação) e de expressividade imediata (sem meios, a não ser os mais naturais) são cruciais nesse trecho. Mourlet admira realizadores que investem o principal de sua energia e de sua inteligência na manutenção da unidade dramática da ação, e condena procedimentos analíticos que contribuam para uma desagregação da ficção e, logo, do mundo. Ele defende uma "estética da centralização, da imediatidade" (Aumont), que não ousa deturpar da cena seu essencial; um olhar que vai "sempre ao que importa na marcha de um evento", e que portanto responde ao que se põe como providência imediata da decupagem. Colocar o espectador "diante do espetáculo, diante do mundo" implica uma frontalidade, uma incontornabilidade do que não pode escapar ao olhar nem à ficção. Essa noção é reforçada num breve texto de introdução à obra de Raoul Walsh ${ }^{82}$ :

[O método] é simples; ainda assim é preciso a ele se ater. Não mostrar de uma cadeia de eventos senão o indispensável a seu desenvolvimento e sua compreensão; mostrá-lo da forma mais direta; sempre permanecer ligado ao centro. Construir, em outros termos, uma arquitetura cuja beleza global nasce da exatidão do papel atribuído a suas partes. (MOURLET, 2008)

O olhar adequado ao modo de apreensão cinematográfica do real é "um olhar clássico ao extremo, ou seja, exato, motivado, equilibrado, uma transparência perfeita através da qual a expressão nua encontra sua mais eficaz intensidade" . "Fazer-se completa transparência, olhar puro, poroso aos fenômenos, é a sabedoria do classicismo e o segredo de uma juventude inalterada" ${ }^{44}$. Como fica claro nessas declarações, o que está no centro não apenas da definição mourletiana de mise en scène, mas de toda a conformação do pensamento crítico impulsionado por seus textos é uma certa noção de beleza inspirada em heranças classicistas.

O sistema hegeliano das artes é bastante presente na argumentação de Mourlet, embora não se faça nenhuma menção explícita a ele. Além do já comentado parentesco entre a visão de Mourlet do cinema mudo e a definição de Hegel da arte simbólica dos egípcios, há

\footnotetext{
82 "Une lucidité virile", em Sur un art ignoré ou la mise en scène comme langage, Paris: Ramsay, Poche Cinéma, 2008.

83 "Sur un art ignoré".

84 "Une lucidité virile".
} 
de se destacar também que as outras duas etapas evolutivas da estética hegeliana, isto é, a arte clássica dos gregos (fusão perfeita da forma e do conteúdo) e a arte romântica (arte cristã) onde triunfa a subjetividade e a interioridade ${ }^{85}$, estarão representadas no pensamento cinematográfico de Mourlet, respectivamente, por um classicismo (sobretudo hollywoodiano) cujo ápice teria se dado entre meados dos anos 1940 e fins dos anos 1950 e por um cinema de autor (ou moderno) de tonalidade subjetiva do qual Cidadão Kane costuma ser apontado como marco inicial. Aumont explica que esse modelo hegeliano - popularizado na França por André Malraux - já estava naturalizado na mentalidade crítica dos anos $1950^{86}$. A realização histórica do ideal clássico, que Hegel buscava na Grécia antiga, Mourlet - e, na verdade, toda uma "escola" da crítica francesa da sua geração - encontrará na "era de ouro" do cinema dos estúdios, que aparece como "uma espécie de equivalente da tragédia clássica, com suas regras e sua arte poética" ${ }^{97}$.

Grandes estetas tardios, como Éric Rohmer e Michel Mourlet, defenderão seriamente a idéia não apenas de que pode existir um classicismo cinematográfico de mesma natureza daquele das outras artes, mas de que, o cinema não tendo ainda atingido seu apogeu, ele possui seu classicismo diante dele. Rohmer daí tirará a conclusão de que ele é superior a todas as outras artes, as quais, tendo há muito ultrapassado essa era clássica, empreenderam sua fase de declínio (“moderno" ou não). (AUMONT, 2007)

A arte clássica, nesse modelo aí incorporado, é aquela em que a união da significação e de sua manifestação exterior é imediata: forma e consciência estão à mesma altura, enquanto as representações da arte simbólica ainda eram explicações acessórias do conteúdo e as da arte romântica já revelarão uma consciência alçada acima das capacidades da arte em traduzi-la. O artista clássico "sabe o que quer e pode o que quer" (Hegel), tem uma idéia perfeitamente clara do conteúdo substancial que deseja tornar perceptível e possui o poder técnico que sua realização exige. Ele encontra sua matéria nas crenças populares, nos eventos de que é testemunha e naqueles que as lendas consignam e que a tradição transmite. Na arte romântica, o mundo espiritual estará destacado do sensível e aparecerá, assim, como um pregueamento sobre si mesmo, mise en abîme da própria subjetividade. A arte clássica, ao contrário disso, busca a presença e união do Absoluto no sensível e fenomênico.

Para Aumont, a adoção do sistema hegeliano acusaria uma "defasagem" no

85 Cf. Vera Lúcia Felício, “A Razão Clássica”, in GUINSBURG, J., O Classicismo, São Paulo: Perspectiva, 1999.

${ }^{86}$ Modernes?, p. 39.

87 Aumont, idem. 
pensamento de Mourlet, que pregaria uma espécie de classicismo romântico (um oxímoro) no momento em que o cinema se punha a esquecer o classicismo e a retrabalhar intensamente as concepções da arte e do artista legadas pelo romantismo, das quais a exaltação da expressão individual do autor seria só a ponta do iceberg ${ }^{88}$.

O mais interessante a se explorar nessa idéia de um "classicismo romântico" é o fato de que, conforme explicado no primeiro capítulo, a emergência do metteur en scène no teatro oitocentista esteve diretamente associada à superação do generalismo da cena classicista em nome da individualidade romântica que, solicitando para cada peça uma abordagem sempre diferenciada da cena, impôs a necessidade de uma instância criativa encarregada de enformar e organizar os espetáculos. A mise en scène viria, entre outras coisas, para conciliar a dramaturgia do texto e do ator às novas demandas cenográficas e visuais da cena. Mourlet, ao teorizar sobre a mise en scène de seus cineastas prediletos, fala da apreensão de um mundo que não é um cenário restrito àquele filme, mas que é o mundo. A verdadeira mise en scène para ele está vinculada à sabedoria de alguns poucos cineastas, de um círculo seleto onde se partilha o segredo da beleza e a clareza para exprimi-la. Essa sabedoria, embora se alimente de sensibilidades individuais que dão ao filme um caráter singular, só pode ser expressa em termos de mise en scène se regida por constantes cósmicas ("sempre permanecer ligado ao centro", por exemplo). O classicismo romântico mourletiano, se é que esta é a melhor forma de classificá-lo, está na teorização de um cinema em que a perfeição da mise en scène é atingida pela sutil harmonia entre a compreensão de uma ordem do cosmo e a liberdade subjetiva que leva a domínios desconhecidos.

O metteur en scène verdadeiro, para Mourlet, é aquele que segue reflexivamente um método, mas que não descarta a fenomenalidade do olhar e a intuição do momento, que nada mais são que um respeito pelo real, uma crença de que há algo nele de essencialmente brutal e imprevisto. A mise en scène não é nem um realismo passivo nem uma folia da ação interventora do homem sobre o mundo; é um acesso à presença das coisas, ao "sentimento do ser" ${ }^{\prime 89}$. Tal presença corresponde aos momentos em que a revelação sensível e a consciência do ato representacional se encostam, em que a aferência do mundo e a do homem se encaixam, em que o artista e seu objeto "se associam no amor" (como diria Goethe); momentos privilegiados em que "uma ação se torna presença da ação, em que um movimento realiza a revelação de uma presença" ${ }^{90}$.

\footnotetext{
88 A análise completa que ele faz do texto está em $O$ cinema e a encenação, pp. 75-125.

89 As dificuldades e ambiguidades sobre as noções de presença e evidência estão muito bem colocadas por Aumont em O cinema e a encenação, pp. 96-100.

90 Aumont, Le cinéna et la mise en scène, Paris: Armand Colin, 2006, p. 97.
} 
Há uma dimensão lírica na mise en scène enaltecida por Mourlet que pode ser traduzida, por exemplo, como uma forma particular de olhar "a cidade, as árvores ou o mar". Num nível primordial, a mise en scène é a ação conjunta de um olhar sobre o mundo e de uma inteligência que organiza a cena. Uma racionalidade muito ambiciosa afugentaria, em parte, a imediatidade do olhar, enfraquecendo-o; mas a consciência também não pode se calar por trás de uma apreensão puramente sensória. $\mathrm{O}$ objeto do olhar e da inteligência que constroem a mise en scène é a "presença corporal dos atores em um cenário", assim como os sentimentos que a narrativa desvela - é o mundo, ou melhor, os aspectos do mundo que se provam capazes de agir imediatamente sobre nossas sensibilidades. A mise en scène segundo Mourlet é tãosomente a forma (ou o "princípio de enformação", como prefere Aumont ${ }^{91}$ ) pela qual se garante, num filme, a presença direta do mundo.

Quando disser que DeMille é superior a Hitchcock, Mourlet criticará “os ângulos insólitos, os enquadramentos bizarros, os movimentos de câmera gratuitos" do diretor de Um Corpo que Cai, que desfiguram o mundo e se contrapõem a "essa franqueza, essa lealdade sobre o corpo do ator que é o único segredo da mise en scène". Surge aqui a outra regra indispensável, a da "preeminência do ator":

Para bem compreender, basta se referir ao recente Vertigo de Hitchcock, ou ainda a um certo plano de O Homem Errado, como exemplos do que não se deve fazer. $\mathrm{O}$ redemoinho da câmera em torno do rosto de Henry Fonda para exprimir sua angústia, ou as colorações sucessivas de James Stewart em meio ao pesadelo da vertigem, procedem da mesma impotência diante do ator, ao suplantar uma incapacidade de revelar suas virtualidades passionais - do interior - por uma crispação de tudo aquilo que não é o ator, de tudo aquilo que está fora dele, da mesma forma que os escritores medíocres forçam o estilo e brutalizam as palavras para tentar dar a sentir o que eles não sentem. (MOURLET, "Sur un art ignoré", 1959)

No trecho acima, Mourlet claramente ecoa uma passagem do texto de Merleau-Ponty "O cinema e a nova psicologia":

[O cinema] não nos proporciona os pensamentos do homem, como o fez o romance durante muito tempo; dá-nos a sua conduta ou o seu comportamento, e nos oferece diretamente esse modo peculiar de estar no mundo, de lidar com as coisas e com os seus semelhantes, que permanece, para nós, visível nos gestos, no olhar, na mímica, definindo com clareza cada pessoa que conhecemos. Se o cinema deseja nos mostrar uma personagem tomada de vertigem, não deve tentar conferir a visão interior da vertigem [...] Sentiremos isso bem

91 Idem, p. 80. 
melhor apreciando exteriormente, contemplando esse corpo desequilibrado a se contorcer sobre um penhasco, ou esse andar vacilante, tentando adaptar-se na desorientação do espaço. Para o cinema, como para a psicologia moderna, a vertigem, o prazer, a dor, o amor, o ódio traduzem comportamento. ${ }^{92}$

O princípio de Merleau-Ponty, que Mourlet retomará, é o de que o cinema anula a separação interior/exterior, vida psíquica/vida motora: a arte de inventar ficções, no cinema, coincide com a pura sensibilidade à imanência dos micromovimentos do universo. "O sentido de uma fita está incorporado a seu ritmo, assim como o sentido de um gesto vem, nele, imediatamente legível" (p. 115). Como diria Jacques Rancière: "Pensamentos e coisas, exterior e interior são capturados na mesma textura, em que o sensível e o inteligível permanecem indistintos" ${ }^{\prime 93}$. Por conseguinte, a câmera não tem motivo para fazer uma pirueta no intuito de exprimir uma vertigem. Ela deve, antes, "decifrar tacitamente o mundo e os homens", "coexistir com eles" (Merleau-Ponty). Não tentar emular a interioridade por intermédio de artifícios de estilo, mas perscrutar os sentimentos interiores através da observação exterior. A verdade de uma cena está no ator, e não no movimento de câmera:

\begin{abstract}
Porque o cinema é um olhar que se substitui ao nosso para nos dar um mundo em acordo com nossos desejos, ele nos colocará sobre rostos, corpos radiantes ou feridos mas sempre belos, dessa glória ou desse fracasso que testemunham uma mesma nobreza original, de uma raça eleita que, com embriaguez, reconhecemos nossa, último avanço da vida rumo a deus. Não, como em Rossellini, a aproximação tateante da criatura rumo a um criador, tema exterior à mise en scène, mas o homem tornado deus na mise en scène, pela revelação de seus poderes, brecha aberta bruscamente na superfície das coisas e nos arrebatando. Hino à glória dos corpos, o cinema reconhece o erotismo como sua motivação suprema. Queremos dizer com isso que o cinema não escolheu o erotismo dentre outras vias possíveis, mas que estando dada sua dupla condição de arte e de olhar sobre a carne, ele estava dotado ao erotismo como reconciliação do homem com sua carne. (MOURLET, "Sur un art ignoré", 1959)
\end{abstract}

A mise en scène defendida por Mourlet não é um movimento rumo ao criador, ou rumo à compreensão de um para-além que preside o mundo dos corpos, como era em Rossellini segundo Rivette e Rohmer. Essa dimensão erótica do cinema, sua condição enquanto olhar sobre a carne, vinha associada em Rossellini ao próprio catolicismo do

92 Merleau-Ponty, "O cinema e a nova psicologia", in XAVIER, Ismail (org.), A Experiência do Cinema, Rio de Janeiro: Graal/Embrafilme, 1983, p. 116.

93 Ver introdução do livro La fable cinématographique. 
cineasta: "nosso corpo também participa do mistério divino, à imagem daquele do Cristo; há nesse culto, que faz da presença carnal um do seus dogmas, um sentido concreto, pesado, quase sensual, da matéria e da carne" ${ }^{\text {94 }}$. Mas na visão de Mourlet - e nisso já reside sua crítica a Rossellini - o homem deve ser o único deus da mise en scène: é ele o herói, cujos gestos e movimentos determinam as coordenadas do espaço. Conforme notou Alain Bergala, este é um aspecto sob o qual Mourlet está avançado em relação aos Cahiers da época: o herói, molamestra da mise en scène, é indissociável do ator que o encarna, cuja escolha, portanto, é capital. Mourlet dirá que "cada metteur en scène possui seus atores benéficos, como cada escritor é apegado a certos seres da linguagem mais que a outros, como cada pintor é atraído por uma cor". "A especificidade do cinema, para Mourlet, consiste em sua capacidade de apreender, captar, registrar as modificações do espaço efetuadas pelo herói, o herói-ator que reina sobre o espaço que o circunda, e não por uma virtuosidade ou enunciação arbitrária do cineasta" 95 . Nenhuma servidão pode prender esse herói a seu criador, o "herói mourletiano se desloca em um espaço aberto, que ele orienta seguindo sua soberana vontade, ele é seu próprio deus", e o cineasta deve dar "a ilusão de submeter sua decupagem, do modo mais invisível possível, a essa liberdade sem entrave de sua criatura". O mundo é uma solicitação permanente, que a mise en scène capta a partir de um eixo definido: o corpo do herói-ator solicitado. É ele que escalona a decupagem e estabelece os ângulos (“toda a energia do fluido misterioso que é a encenação passa pelo corpo do ator" ${ }^{\text {"96 }}$ ). Por isso um Hitchcock, para quem "o melhor ator de cinema é aquele que sabe melhor não fazer nada", deixando que a câmera construa todos os efeitos, ou um Bresson, para quem os atores são "modelos", estarão excluídos do sistema mourletiano.

Eisenstein, por tratar os atores como meros componentes gráficos do plano e fazer do cinema uma arte por demais analítica, onde prevalece a descontinuidade e o fragmento, também será criticado. Tanto para Eisenstein como para Hitchcock, o cinema não tem cena, mas espectadores sentados numa sala diante de uma tela na qual aparece a imagem de um mundo essencialmente mental. Encenar, para eles, é um processo de decomposição abstrato, ideal, que divide a ação em pequenos fragmentos, depois tratados um por um - sua unidade é alcançada pelos meios mais abstratos ${ }^{97}$. Assim sendo, as encenações hitchcockiana e eisensteiniana são uma construção imaginária, que tem de encontrar correspondência no mundo sensível e na realização prática, mas que nunca os reflete senão pelo filtro de um olhar

94 "Lettre sur Rossellini".

95 Alain Bergala, "Sur un art ignoré, côté face", in AUMONT, Jacques (dir.), Le Septième Art, Paris: Éditions Léo Scheer, 2003.

96 Aumont, O cinema e a encenação, p. 85.

97 Ver Aumont, O Cinema e a encenação, pp. 142-143. 
convulsivo, afastando-se da observação exata, das iluminações do real, abdicando de ser uma "arte feita na unidade bruta e na espessura do mundo" (Valéry), características imprescindíveis para Mourlet. Sua definição de mise en scène é tão determinante naquilo que afirma quanto naquilo que nega: a lista de seus cineastas detestados é tão reveladora quanto a de seus prediletos. De Welles, ele será ainda mais detrator, e dirá que seu "modernismo agressivo" e sua "originalidade gratuita recobrem um expressionismo velho de um quarto de século", uma "galeria de monstros pitorescos, barroca se o barroco se define por uma abundância ornamental do signo sufocando a significação". Está claro que o "golpe de estado wellesiano" louvado por Rivette é inteiramente desaprovado por Mourlet. À narrativa virtuosa de Cidadão Kane, a todo o sistema retórico construído pela montagem, à abundância de recursos expressivos (angulações inusitadas, movimentos de câmera mirabolantes, "contraplongées sistemáticos e inúteis"), ele preferiria uma narrativa que fosse a estrutura estável sobre a qual a mise en scène se desenvolveria em vista tão-somente do necessário.

Ora, se o horizonte estético de Mourlet é o classicismo, conseqüentemente ele irá combater essa noção romântica do super-autor cuja consciência - inflada - se eleva acima da forma. O conceito de mise en scène que Mourlet desenvolve, como tradução de uma essência e de um absoluto, acaba servindo de emblema para uma recusa das arbitrariedades autorais de certos realizadores. Uma mise en scène em que a mise predomine sobre a scène estará automaticamente se distanciando de suas premissas. Em primeiro lugar deve estar a cena e o drama (o que neste caso equivale a dizer: o mundo), e não o universo particular do autor, nem seus super-poderes. Mourlet não quer uma arte que sabe transformar o chumbo em ouro, mas uma arte que é pura contemplação do ouro ${ }^{98}$. Seu texto sobre a primeira fase da carreira de Losey, "Beleza do conhecimento" ("Beauté de la connaissance", Cahiers du Cinéma no 111, setembro de 1960), é bastante esclarecedor a esse respeito:

A maioria dos realizadores projeta sobre o mundo o seu sistema, a vagueza de seu olhar, a distorção de sua inteligência. Uma obra nula é antes uma obra falsa, um espelho que deforma. Nós andamos por esses filmes como em um sonho ruim, esbarrando a cada instante em objetos irreconhecíveis. Nosso bom senso consistirá então em fugir dessa sufocante esfera de artifício, em retornar à verdade que banha por todos os lados a sala de cinema e vem bater nas suas portas sem nela penetrar.

Ora, Losey é o realizador cujo espelho é de uma água tão pura que se faz esquecer e somente a realidade, em seus filmes, se desvela diante de nós. Olhos desavisados, unicamente sensíveis às

98 Ver o elogio que ele faz de Edward Ludwig em "Billet Londonien”, Cahiers du Cinéma no 102, dezembro de 1959. 
provocações de ordem wellesiana, podem confundir essa nudez do verdadeiro com a destituição da maioria. (MOURLET, 1960)

A limpidez da estética de Losey, a "nudez" de seu olhar (sobre a qual Pierre Rissient, no mesmo número da Cahiers, discorrerá muito bem ${ }^{99}$ ) corresponde a "uma inteligência que se deixa investir pela ordem das coisas", ao invés de tentar dobrar essa ordem a um desejo ou a uma distorção imaginativa. A razão não é uma luz projetada nas coisas pelo espírito do homem, mas algo que já se encontra nas coisas, e que o homem precisa deixar "vir por si mesma” (essa fenomenologia do estar-aí também se achava presente para Rivette e Rohmer, só que, ao menos no caso de Rossellini, acrescentada de um “desenho do criador”). Losey, segundo Mourlet, é o único realizador "que sabe impor constantemente a presença do mundo, o peso do ambiente sobre o centro da cena, pela utilização dos ruídos, das luzes, pela identificação do cenário ao drama e do drama ao cenário. O núcleo do drama se assemelha então ao coração ardente de um sol cujos raios se prolongam e vibram indefinidamente no espaço". Drama e espaço precisam coincidir, ter a mesma identidade. De acordo com essa lógica, os cenários de Losey jamais trazem marcas de enunciação gratuitas, pois são absolutamente indissociáveis de sua atividade como suporte natural do drama. Losey não estiliza o espaço; seu interesse se direciona ao mundo, e não aos artifícios da inteligência; ele rejeita toda "sensibilidade caricatural", para guardar do mundo sua imagem mais límpida, mais exata, mais "honesta", menos adulterada:

Nessa perspectiva, Hitchcock tem um estilo e Losey não. A noção de
estilo recobre por conseguinte um direcionamento do verdadeiro:
Hitchcock, Welles, Eisenstein inventam formas, certamente, mas
essa constatação não é a mais severa das críticas? O artista não
inventa, ele descobre, senão nós nos curamos de seus fantasmas. A
história da arte é em grande parte a história das doenças do espírito.
Pouquíssimos artistas seguiram a estrada retilínea do olhar puro. O
olhar puro quer dizer essa perfeita limpidez da consciência no fundo
da qual as formas verdadeiras do mundo se desenham, e a que se
chama também inteligência porque, conforme veremos, a
inteligência e a beleza não se separam. (MOURLET, 1960)

Mourlet vai sempre preferir o olhar puro sobre as coisas aos estados patológicos da imaginação. Nem que isso subtraia ao artista o estilo, ou pelo menos aquilo que se costuma qualificar como estilo. O verdadeiro artista não é o que inventa formas, mas o que descobre, suscita "clarões sucessivos", retira parcialmente a casca que protege a realidade e nos abre a via do conhecimento, nos permitindo ver a polpa do mundo (sua beleza) por alguns instantes,

99 “Connaissance de Joseph Losey”. Trata-se de uma referência obrigatória sobre o cineasta. 
mesmo que ela permaneça recoberta (estamos tocando, ainda que de leve, as noções heideggerianas de presença e fenômeno ${ }^{100}$ ). "O mundo aparece em seu frescor brutal - mas a inteligência é adulta e não se rompe sob o choque [...] A mise en scène de Losey, como a escrita de Valéry, é a cada segundo um ato de conhecimento, o olhar de um olho virgem e a conquista de um espírito desprevenido". A arte para Mourlet é a "religião da lucidez", e essa religião estabelece como dogma inaugural a necessidade de se ater às evidências do mundo, para daí extrair toda forma de conhecimento (inclusive a razão em seu estágio mais elevado). "Passou o tempo de buscar o segredo do mundo. Através do furor e da tragédia, assim como nas alegrias mais fervorosas, é questão de nada mais que aprender a viver".

Em "Beleza do conhecimento", Mourlet nos faz pensar no sentido último do classicismo em Goethe: oriente-se pelo mundo real e procure expressá-lo, pois era isso que os antigos também faziam, já que viviam. Nasce daí uma crítica ao artista que, ao invés de se ater ao objeto, derrama-se em sua subjetividade. Para Goethe, é preciso ser capaz de lutar contra a própria tendência a se exercitar no que é imediatamente estranho - os modernos são o oposto dos antigos justamente porque possuem a doença da subjetividade: "Clássico é o que é são, romântico o que é doente"101. Quando Mourlet separar um Losey clássico de um Losey moderno, ele estará "diagnosticando", em dois momentos diferentes de uma mesma filmografia, respectivamente um artista são e um artista doente. No texto em que faz essa separação, "Joseph Losey face ao público"102, Mourlet retorna ao modelo hegeliano, desta vez até com um certo didatismo, concentrando-se no momento de transição do clássico para o moderno. Losey seria exemplar para uma tal demonstração, pois sua obra faz essa transição mesmo que de modo não exatamente esquemático (o esquema serve apenas para representar o “esboço geral do problema”) -, permitindo que se veja com mais clareza os motivos que levam à decadência de um ciclo e à instauração de outro.

Há dois comportamentos face à decadência: aceitá-la ou recusá-la. Aceitar é "se refugiar no desprezo ou na agressão", embarcar no caos e ser seu registrador complacente. A outra atitude já seria mais nobre:

Recusar-se a conformar e a integrar sua criação à decomposição que os rodeia é próprio dos cineastas que, menos atingidos pelo envelhecimento de sua coletividade, desejarão salvá-la mais do que traí-la. Distanciados de todo romantismo e em particular do culto exacerbado ao individual na arte, eles conservam junto ao público uma atitude clássica de respeito. [...] Esses aspiram menos a cuspir

\footnotetext{
100 Ver HEIDEGGER, Martin, Ser e tempo - parte I, 14ª ed., Rio de Janeiro: Vozes, 2005.

101 Ver a introdução de Marco Aurélio Werle para Escritos sobre arte, de Goethe.

102 O texto, traduzido para o português, foi publicado em Contracampo $\mathrm{n}^{\circ} 92$ (http://www.contracampo.com.br/92/artloseymourlet2.htm).
} 
no rosto do espectador do que a lhe trazer a beleza, o ensinamento, o apaziguamento, quiçá o divertimento que eles têm missão e vocação de fazer jorrar do deserto. (MOURLET, 1969)

O culto ao autor é novamente tido como indesejável, sendo que este culto, no momento em que Mourlet escreve esse texto (final dos anos 1960), responde pela maior parcela da receita da crítica ${ }^{103}$. Na sua primeira fase, até fins dos anos 1950, Losey teria sido um quase-demiurgo e se comunicado com todos os públicos: "Que uma obra não seja recebida da mesma forma por todos os homens, é a evidência. Mas há numa obra realmente grande bastante clareza, emoção e universalidade para concernir a todos os homens. É a lição do classicismo americano de um Losey (O Menino dos Cabelos Verdes, The Lawless...)". A partir de um dado momento, ele abandonaria esse universalismo em razão, dentre outras coisas, do contato com um certo círculo de intelectuais europeus:

O período europeu de nosso cineasta complica um pouco esses dados. Não que ele desvie do público para buscar somente os aplausos dos colegas. Seus filmes não param de trazer a marca de uma firme vontade de comunicação. A "história", elemento de base, esqueleto indispensável para segurar as carnes, é neles contada da forma mais explícita e mais direta. Losey não busca nem a falsa ambigüidade nem embaralhar as pistas para desconcertar o espectador por artifícios da forma. Com raras exceções, se o espectador é desconcertado, será por aquilo que o filme mostra, não pela maneira como ele mostra. Em termos mais abruptos, tendo alguma coisa a fazer e a mostrar, Losey não é impelido a adulterar a matéria para dela se fazer valer. (MOURLET, 1969)

No exílio europeu, Losey teria abandonado a franqueza e a simplicidade de sua fase americana para se entregar a uma forma mais sinuosa, encurvada, "enriquecida de preciosidade", nutrida por roteiros com singularidades demais e generalidades de menos, o que contradiz o propósito da arte clássica, que não é diferenciar e individualizar mas chegar ao geral e ao típico, fixar o universalmente humano com clareza e regularidade. "Isso não significa que o caráter excepcional de uma situação ou de um personagem lhes tire obrigatoriamente seu poder de exemplo e de generalidade. Ao contrário, muito melhor que a banalidade cotidiana, o excepcional pode atingir a amplitude, a profundidade, a grandeza que esperamos de uma obra para que ela nos toque o coração e o espírito”. Mourlet já tratava

103 Aumont trata do tema em $O$ cinema e a encenação: "no cinema de autor francês do fim dos anos 60 , e também no que se produz mundialmente sob o nome de 'novo cinema' ou 'jovem cinema', é a concepção do 'eu' do autor manifestado pela montagem (a vontade de potência) que conta, e a mise en scène no sentido de exercício do olhar atravessado de tensões mas finalmente apaziguado, dionisíaco-apolíneo, à la Mourlet, não tem mais curso". 
desse assunto em "Sobre uma arte ignorada": não interessa nem a banalidade extrema, nem o excessivamente singular, mas um equilíbrio que permite prospectar, no mundo de todos os dias, o extraordinário e grandioso. Em termos de drama, é como se Mourlet visasse sempre o reino sereno do classicismo, porém intensificado pelo herói visceral do romantismo.

Cabe aqui uma breve análise da torção interna da obra de Losey a que Mourlet se refere quando fala do "período europeu” do cineasta. É entre 1954 e 1959, começando com The Sleeping Tiger e continuando - de modo variável - com A Sombra da Forca, The Gipsy and the Gentleman e Blind Date, que ocorre uma primeira investida barroca na obra de Losey, condensada depois em Eva (1962) e O Criado (1963). A mudança crucial de que estamos falando reside não só na decupagem e na preparação dos cenários, mas também na iluminação, nos diálogos, nos atores, em suma, na compleição geral dos filmes. Tudo começa na concepção das idéias de base, ou seja, na maneira de trabalhar a disposição dos materiais para que eles recebam, com uma margem de erro reduzida, a forma. O estilo visual dos filmes, sobretudo a partir da parceria com Richard MacDonald (que tem início tão-logo Losey se instala na Inglaterra), vai ser concebido numa etapa de pré-designing: após lido o roteiro, Losey e MacDonald conversam sobre a história e começam a pôr em desenhos - portanto em uma "linguagem" já propriamente visual - aquilo que pretendem executar nos cenários e nas locações. Questão de método.

Losey não irá adulterar a matéria, não irá desrespeitá-la, mas o caminho entre ela e a forma deixará de ser retilíneo. Antes, o mundo e a forma escolhida para representá-lo tinham o mesmo tamanho. Agora, é como se Losey estivesse tentando fazer esse mundo passar, todo ele, por uma serpentina. O conteúdo é grande demais, e obriga o continente a multiplicar seus efeitos de vertigem e de dobra. Disso resulta uma dramatização torrencial, uma intensidade da forma completamente diferente daquela serenidade que existia em $O$ Menino dos Cabelos Verdes (1948), primeiro longa de Losey, sobre o qual Mourlet havia dito que se tratava do “equivalente exato da música de Bach, uma contemplação bem-aventurada da simplicidade, o mais belo filme de toda a história do cinema [...] uma espécie de graça no movimento da mise en scène, ao mesmo tempo muito evidente e muito secreta, que torna o filme impossível de ser descrito" $" 104$.

O momento-chave da carreira de Losey, que leva Mourlet a escrever "Joseph Losey face ao público", é quando o cineasta decide abraçar ao mesmo tempo os dois pólos da dualidade: "Ele assume o risco de agradar e de desagradar ao mesmo tempo, levando ao coração da corrupção (corrupção sobretudo da verdade) um fino escalpelo de ouro cujo brilho,

104 "Billet Londonien", p. 41. 
elegância e precisão se misturam estreitamente ao horror que ele disseca. Um horror que tem também, aliás, suas belezas, e mesmo suas alegrias, pois nada é branco ou preto, salvo nos filmes ruins. Cerimônia Secreta ilustra à maravilha essa ambivalência”. O ápice e o limite do barroquismo loseyano estariam no esplendor estético que parece em luta com a heterogeneidade da matéria em Cerimônia Secreta e, principalmente, Boom. Neste, que hoje nos soa como um dos filmes mais secretos de Losey, de acesso mais restrito, o paroxismo do barroco consiste na figura antitética de uma beleza que é destruição e vice-versa.

Voltando ao pensamento de Mourlet: o que está no cerne da mise en scène, para ele, é a busca de um "equilíbrio entre o mundo e o homem", tensão rumo ao "acordo de um gesto e de um espaço". Sob certas condições, essa relação homem-mundo se tornará mais intensa. É o que Mourlet demonstra no caso das guerras, e da violência de uma forma geral. A guerra precipita os heróis sobre os momentos mais exacerbados da vida: seu espaço nada mais é que uma versão intensificada do meio social e natural dos homens, "multiplicando os ódios, os obstáculos, o medo, a morte, mas também a amizade e, quando ele se apresenta, o repouso" 105 . A guerra é "um meio de conhecimento", "o revelador químico do homem desnudado". Cineastas como Raoul Walsh e Allan Dwan, em filmes como Um Punhado de Bravos (Objective, Burma!, 1945) ou Iwo Jima - O Portal da Glória (Sands of Iwo Jima, 1949), respectivamente, representam os ápices desse "milieu excepcional” que é o filme de guerra:

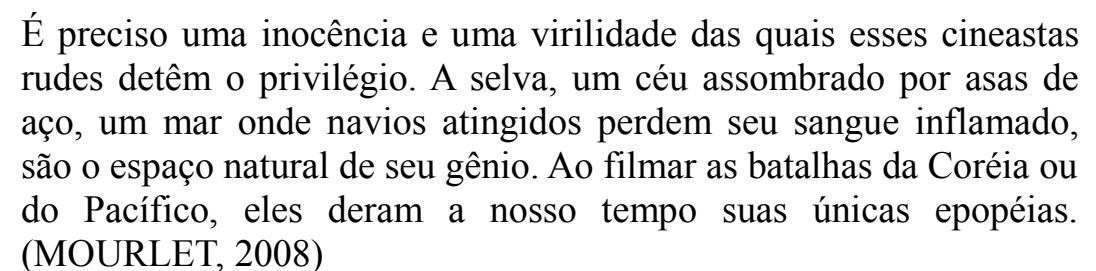

É preciso uma inocência e uma virilidade das quais esses cineastas rudes detêm o privilégio. A selva, um céu assombrado por asas de aço, um mar onde navios atingidos perdem seu sangue inflamado, são o espaço natural de seu gênio. Ao filmar as batalhas da Coréia ou (MOURLET, 2008)

A violência valoriza a mise en scène, sublinha o combate que está na base de toda criação artística e que, no cinema, recebe uma "encarnação no mundo material e objetivo". Num de seus textos mais famosos, "Apologia da violência" ("Apologie de la violence", Cahiers du Cinéma, maio de 1960), Mourlet monta um sistema estético a partir da representação da violência em alguns cineastas escolhidos a dedo. Tendo definido que "o cinema é a arte mais afinada à violência, já que a violência esguicha das ações do homem”, Mourlet expande suas proposições acerca da preeminência do ator no cinema ${ }^{106}$. "Elevando o 105 “Le film de guerre”, em Sur un art ignoré ou la mise en scène comme langage, Paris: Ramsay, Poche Cinéma, 2008.

106 Há um famoso parágrafo sobre Charlton Heston em "Apologia da violência": "Charlton Heston é um axioma. Ele constitui em si mesmo a tragédia, sua presença em qualquer filme sendo suficiente para instilar beleza. A violência reprimida expressa pela sombria fosforescência de seus olhos, seu perfil de águia, o imperioso arco de seus supercílios, a curva amarga e rígida de seus lábios, a estupenda força de seu torso - 
ator, a mise en scène encontra na violência uma constante fonte de beleza". É da violência que sai "a mise en scène em sua forma mais pura", mais atrelada ao drama do corpo, ao "gosto pela ação efetiva". Em Walsh, Mourlet encontra uma "violência límpida e direta", violência a céu aberto, solar, epopéica, "violência da guerra ou do conquistador solitário, e o que ela expressa é a coragem de viver, uma consciência da luta entre o homem e os elementos, homem contra homem, uma liberação da vontade de vencer”. Já em Lang, a violência é o oposto do que era em Walsh: subterrânea, tubular, noturna, "constrangida, recuada, explícita e latente em todo ato e todo olhar". Violência mais duradoura em sua tragédia: "Somente o terror a libera; a terra estremece ao seu redor e o herói é tragado". O último estágio da violência é Losey, "cineasta que vai mais fundo na violência e a demonstra melhor que ninguém":

A violência em Losey está apenas sob a pele, captando aquele momento em que o pulso freneticamente se acelera enquanto com cada batimento cardíaco magnificado um homem se prepara para encarar o que está em seu caminho. E nesse processo, descobre uma calma, uma detumescência. Essa é uma violência que abre uma porta para a paz e anuncia um inusitado banquete de felicidade. (MOURLET, 1960)

Se Losey, para Mourlet, é o grande metteur en scène da violência, o da tragédia, por sua vez, será Lang. Em “Trajectoire de Fritz Lang” (Cahiers n 99, setembro de 1959), ele fala de "narrativas insignificantes cuja significação está encarcerada na mise en scène, significação unicamente passional, portanto unicamente estética, não mais conceitual mas melódica, graças à qual entre as mãos de Fritz Lang, como entre aquelas de alguns raros cineastas, o cinema ascende à dignidade de arte". Não há mise en scène, no sentido em que Mourlet a está definindo, senão na identidade absoluta entre a significação e sua manifestação sensível, a mise en scène encerrando em si mesma sua significação, a narrativa progredindo enquanto apaga seus rastros. A fascinação se completa pela interiorização de um depuro matemático, "esquema abstrato que é a beleza pura liberta das condições que a sustentam", e "que não deforma mais as aparências, mas as escolhe e as ordena sobre um substrato passional": a partir da "era culminante" da obra de Lang, que segundo Mourlet começa em torno de 1948, as complicações se acham dela excluídas. "Uma tal abstração sente a cor como

isso é o que lhe foi dado, e que nem mesmo o pior dos diretores pode desqualificar. É nesse sentido que se pode dizer que Charlton Heston, por sua própria existência e independentemente do filme em que ele está, fornece uma definição mais acurada do cinema do que filmes como Hiroshima mon amour ou Cidadão Kane, filmes cuja estética ou ignora ou repudia Charlton Heston. Através dele, a mise en scène pode confrontar o mais intenso dos conflitos e resolvê-los com a opulência de um deus aprisionado, guardado em raiva muda. Nesse sentido, Heston é um guerreiro mais walshiano do que languiano". 
um incômodo, ou no mínimo como um elemento supérfluo, e tende ao preto-e-branco que revela diretamente o essencial sem pegar os atalhos do realismo concreto. Mesmo as cores do dístico indiano brilham de um brilho atenuado, por um refinamento de sobriedade que não se contradiz, que sustenta ao contrário esse universo puramente inteligível”.

Em Suplício de uma Alma (seu último filme americano, de 1956), Lang opera no limite do classicismo: aborda seu trabalho com um conteúdo já todo pronto, todo formado, que não dá lugar à dúvida e à hesitação (curiosamente, o título original de Suplício de uma Alma é Beyond a Reasonable Doubt). "É o conteúdo mesmo que, na arte clássica, determina livremente sua forma, de modo que o artista parece não executar senão aquilo que está já implicado no conceito. E enquanto o artista simbólico busca impor a forma à significação ou a significação à forma, o artista clássico modela a significação, lhe dá uma forma exterior, despindo-a de todos seus elementos e lados acessórios, que são sem importância para a significação" ${ }^{107}$.

Suplício de uma Alma conta a história de uma farsa jurídica criada no intuito de desmascarar os mecanismos falhos da justiça e da pena de morte: todas as evidências recolhidas levam a crer que o personagem de Dana Andrews é culpado, mas no fundo ele havia, ao lado do sogro (que é editor de um jornal), forjado essa auto-incriminação e detinha meios de, posteriormente, provar sua inocência (quem viu o filme, no entanto, sabe quais serão os desenlaces). A luta de Dana Andrews é para encobrir a verdade por meio do verossímil. Através de um experimento existencial, ele inventa um fato verdadeiro à luz da justiça, para depois destruí-lo com base num outro fato, verdadeiro à luz das evidências que extrapolam a justiça e a declaram insuficiente, débil, incompleta diante de uma verdade supostamente maior e coincidente com a verdade do mundo. Só que nos dois casos tratam-se de aparências enganosas, deformadoras, e o filme as destrói. A própria evidência do mundo parece colocada à prova de si mesma.

Lang promove nesse filme uma destruição integral das aparências estáticas, para pôr em seu lugar "um aparecer permanente, um dinamismo da presença do mundo" 108 . "A mise en scène no sentido mais etimológico da palavra é erigida em fim último [...] os gestos, os rostos, as vozes e os cenários nos satisfazem menos pelo que são do que pelo que se tornam, e mais precisamente pela forma inelutável desse devir" ${ }^{\prime 109}$. Lang teria atingido o limite a partir do qual a mise en scène desaguaria na ausência de mise en scène: "Uma maior dominação da matéria resultaria na sua supressão e ultrapassaria o papel mediador da arte", diz Mourlet. É a

107 Hegel, op. cit., p. 27.

108 Aumont, $O$ cinema e a encenação, 99.

109 Mourlet, "Trajectoire de Fritz Lang". 
dialética trágica em "estado puro", o signo se tornando insignificante, o elemento original se expondo diretamente ${ }^{110}$. Cada evento já é em si sua narração, cada objeto sua mise en place, cada corpo sua mise en scène; contemplamos um mundo onde tudo é necessidade: a própria ordem do Destino, a cuja arquitetura Lang confia a mise en scène (esta disfarça a presciência do realizador ao apresentar cada acontecimento como surgimento e descoberta). Um olhar que age com clareza, lucidez e ponderação mesmo face ao trágico e ao dilacerante (ou melhor, sobretudo face ao trágico e ao dilacerante). O universo fechado de Fritz Lang, sufocante, asfixiante, apresentado como um teorema irrefutável, de repente se revela submetido a uma lei que é a lei do mundo e não a dos homens, puro reenvio das coisas a si mesmas, ou, mais ainda, à sua origem.

Eis porque Mourlet, quando diz que "tudo está na mise en scène", atribui aos últimos filmes de Lang a "perfeição suprema”. Nesses filmes (Mourlet se refere sobretudo aos últimos filmes americanos, como While the City Sleeps e Suplício de uma Alma, e ao dístico indiano), a mise en scène é decantada por uma "narrativa que desemboca inteiramente sobre o terreno das relações do homem e do mundo, esse mundo que não lhe pertence”. Tudo está na mise en scène, e o cinema está no homem, nas variações da sua relação com o outro e com o mundo. $\mathrm{Na}$ medida em que tais variações se fazem legíveis no espaço e no tempo, se presentificam na atitude corporal dos atores e causam fascínio sobre o espectador, revela-se o poder da mise en scène. Através da tríade presença/mise en scène/fascinação, Mourlet constrói uma verdadeira cosmologia estética.

\section{Do sublime e da abjeção}

No momento em que Mourlet escreve os textos que acabamos de analisar, fazer cinema, ao menos na visão dele, é buscar um maior ou um menor acordo com o mundo. A mise en scène seria, no melhor dos casos, simultaneamente a busca e a expressão desse acordo. No pior, seria a imposição do olhar de um autor sobre o mundo. Embora para ambos a mise en scène seja irredutível à noção de estilo ou de técnica, há uma grande divergência entre Mourlet e Rivette que reside no que este segundo já defendia em "Lettre sur Rossellini" e

$\overline{110}$ Mourlet parece evocar o conceito de tragédia de Friedrich Hölderlin: "Ora, no trágico, o signo é em si mesmo insignificante e sem efeito, mas o elemento original é diretamente exposto. Assim, o original só pode aparecer propriamente em sua fraqueza, mas, à medida que o signo em si mesmo é considerado como insignificante $=0$, o elemento original, o fundamento oculto de cada natureza, também pode se apresentar" ("O significado da tragédia", in SZONDI, Peter, Ensaio sobre o trágico, Rio de Janeiro: Jorge Zahar, 2004, p. $33)$. 
depois reforçará: o que mais importa não são "problemas da forma e do conteúdo, do realismo e do feérico, do roteiro e da 'misenscène', do ator livre ou dominado", mas "o ponto de vista de um homem, o autor, mal necessário, e a atitude que toma esse homem em relação àquilo que ele filma, e assim em relação ao mundo e a todas as coisas" ${ }^{\prime 11}$ :

Fazer um filme é mostrar certas coisas, é ao mesmo tempo, e pela mesma operação, mostrá-las por um certo viés; esses dois atos são rigorosamente indissociáveis. Da mesma forma que não pode haver absoluto da mise-en-scène, pois não há mise-en-scène no absoluto, da mesma forma o cinema nunca será uma "linguagem": as relações do signo ao significado não funcionam aqui. (RIVETTE, 1961)

Essa idéia seria discutível para Rohmer (para quem a beleza das coisas é elemento primordial e, assim sendo, independe do ângulo sob o qual um cineasta nos força a descobrilas) e inaceitável para Mourlet. Enquanto "Sobre uma arte ignorada" se empenha em deduzir a fenomenalidade da mise en scène de um princípio absoluto, ou de um princípio "cósmico", Rivette a deduz de um relativismo, a seu ver, incontornável. Nesta concepção de Rivette, a mise en scène já é menos síntese do que adição, menos unidade do que análise, menos a conquista de um acordo do que o enfrentamento e a expressão de um conflito.

Nesse mesmo ano de 1961 em que Rivette condena o famigerado travelling de $K_{a p o}{ }^{112}$, Rohmer escreve o já comentado "Le goût de la beauté", manifesto estético em favor da beleza publicado nos Cahiers exatamente um número depois do texto de Rivette. Os próprios títulos dos textos se opõem: um fala da beleza, o outro da abjeção. Não à toa foi Rohmer que, dois anos antes, numa mesa redonda sobre Hiroshima Mon Amour, se disse incomodado com a primeira meia-hora do filme, que consiste naquelas avassaladoras imagens mostrando os horrores causados pela bomba atômica no Japão ${ }^{113}$. Enquanto o cinema encara de frente, mesmo que com um atraso de mais de uma década, os maiores horrores da Segunda Guerra, e a crítica traça uma linha divisória entre o bom e o abjeto, o justo e o imoral, Rohmer

111 Ver "Da abjeção" (Cahiers du Cinéma, no 120, junho de 1961), crítica de Rivette para o filme Kapò, de Gillo Pontecorvo. Em meio à sua argumentação, Rivette faz uma clara alusão ao mac-mahonismo e, em particular, ao texto "Sobre uma arte ignorada", opondo-se a ele e até fazendo pilhéria de alguns de seus pontos (a questão do "documentário e da feeria", da "preeminência do ator" etc), como fica claro na forma jocosa de escrever mise en scène como "misenscène".

112 Eis o mais famoso trecho de "Da abjeção": "Basta ver, entretanto, em Kapò, o plano em que [a atriz Emmanuelle] Riva se suicida, jogando-se sobre o arame farpado eletrificado; o homem que decide, nesse momento, fazer um travelling para a frente para reenquadrar o cadáver em contra-plongée, tomando cuidado para inscrever exatamente a mão levantada num ângulo de seu enquadramento final, esse homem só tem direito ao mais profundo desprezo".

113 Cf. "Hiroshima notre amour", em Cahiers du Cinéma no 97, julho de 1959. Quando Rohmer confessa seu mal-estar, Jacques Doniol-Valcroze pergunta se ele se sentiu incomodado "esteticamente ou moralmente", ao que Godard intervém com o famoso axioma parafraseado de Luc Moullet: "É a mesma coisa. Os travellings são questão de moral." 
- e nisso ele está totalmente em sintonia com o mac-mahonismo - continua em busca da Beleza, termo já “obsoleto” em 1961, ainda mais se encarado de forma tão maiúscula.

Assim como Rohmer, Mourlet e os mac-mahonistas foram clássicos no justo momento em que o cinema era declarado (com todas as imprecisões que o termo evoca ${ }^{114}$ ) "moderno". Talvez devêssemos dizer "neoclássicos" - a começar pelo fato de que a crítica mac-mahonista nascia de um esforço para definir a mise en scène que se assemelha à dupla frente de recusa do Neoclassicismo:

Enquanto o renascimento só tinha de combater uma forma de decadência artística, a ausência de estudo e de observação da natureza, o Neoclassicismo tinha de combater não só um modo amaneirado de pintar, mas também uma outra corrente artística que, na vertente oposta, parecia-lhe constituir um excesso igualmente perigoso, ou seja, o "naturalismo" de Caravaggio (cujos aspectos antinaturalistas eram aliás freqüentemente negligenciados). (PANOFSKY, 2000)

$\mathrm{Na}$ análise de "Sobre uma arte ignorada", observamos que nem as estilizações de Welles ou Hitchcock, por demais afastadas do mundo objetivo da natureza e da matéria, nem muito menos o realismo proposto por Zavattini tinham lugar na estética aprovada por Mourlet. Na verdade, ele se opunha a essas duas vertentes com bastante vigor e, não raro, virulência. Os mac-mahonistas levariam adiante essa postura: o cinema, para eles, teria necessidade absoluta da natureza como de um substrato ou material que seria preciso purificar, mas, de modo não menos absoluto, não poderia se limitar à natureza "ordinária", ainda não submetida ao processo de purificação, donde resultava que a mera imitação da natureza teria apenas um valor inferior. Uma das marcas timbradas do mac-mahonismo seria uma enorme restritividade, uma crença tenaz de que o melhor cinema só se encontra ao termo de uma grande exigência do juízo de gosto e da crítica. Eles certamente concordariam com a afirmação de Goethe de que "o belo é um círculo estreito, no qual podemos nos mover apenas modestamente" 115 . Os mac-mahonistas se apegaram à sua quadra de ases - e a mais alguns nomes - da mesma forma que Goethe (e Winckelmann antes dele) se apegou à escultura do Laocoonte como ideal supremo de beleza.

"Se é verdade que a arte neoclássica se define como uma arte clássica que tomou consciência de seu ser próprio, a partir de um passado e no seio de um presente que já não são clássicos, o mesmo vale para a teoria neoclássica da arte": essa concatenação de Panofsky serve para explicar, de certa forma, o que acontece na Présence du Cinéma nos seus anos de 114 Ver Aumont, Moderne?.

115 "O ensaio sobre a pintura de Diderot (1798)", em Escritos sobre a arte, p. 157. 
vida entre 1959 e 1967. Na derradeira edição 24-25 da Présence, que conta com um extraordinário dossiê sobre Cecil B. DeMille, há um extenso artigo de Jacques Lourcelles em formato de diário, com o título "Journal de 1966". Após falar dos principais filmes vistos no ano anterior, Lourcelles encerra o texto - e a revista - acenando "Adeus ao macmahonismo" $" 116$. O texto possui um tom bastante aterrador:

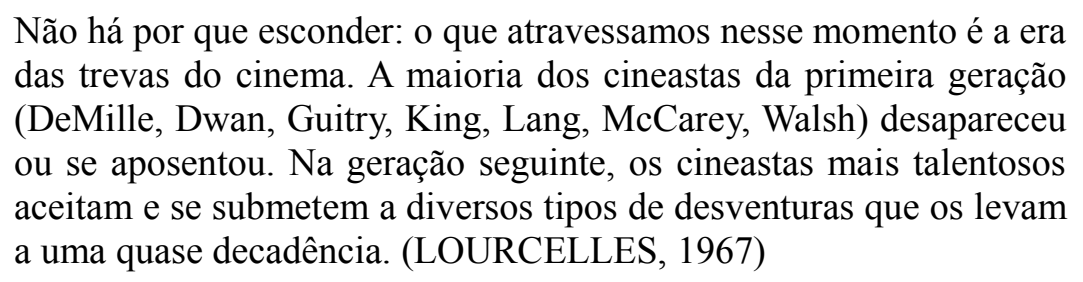

Enquanto se celebram os cinemas novos ao redor do mundo, e se alimentam esperanças em relação à nova geração de cineastas americanos (Arthur Penn, Sam Peckinpah, Sidney Lumet), Lourcelles assiste melancolicamente a uma dissolução do cinema clássico em seu próprio domínio (a exemplo da decadência do clássico em outras artes e em outros períodos). Com relação ao cinema francês, sua atitude é ainda mais pessimista: "Os nomes de Deray, Sautet, Deville etc. vêm assim se juntar àqueles de Truffaut, Chabrol, Melville, Lelouch, Resnais, Astruc, Malle etc., para constituir um cinema confortável, satisfeito, amortecido, sem risco, quase sem relação com a realidade: o modelo perfeito de um cinema pequeno-burguês do qual o cinema francês jamais, em nenhum momento de sua história, havia chegado tão perto" (p. 102). Tudo que Lourcelles vê na França da Nouvelle Vague e do noir blasé de Jean-Pierre Melville é um cinema que, ao invés de se enriquecer com o conhecimento do mundo real, se deixa face a face com suas idéias e convicções, optando por um anestesiamento generalizado que ele considera imperdoável.

Mesmo alguns dos prediletos de outrora parecem sem brilho naquele momento para Lourcelles: uns, por razões econômicas, aceitam orçamentos tão irrisórios quanto paralisantes, outros trabalham na televisão, onde a iniciativa e o talento dos diretores quase nunca conseguem triunfar sobre os interesses comerciais dos executivos das emissoras. "Outros, aparentemente mais sortudos (Losey, Donen), filmam, mas no vazio e no contra-senso. Losey foi muito bem aceito no clã do pior cinema intelectual europeu. Seus últimos filmes (King and Country, Modesty Blaise) são pobres, mecânicos, sem força e sem humor. O sucesso no exílio terá sido sua prisão dourada" (p. 103). Nem Losey, que em outro momento significou o supra-sumo do mac-mahonismo, se salva.

116 “20 Décembre. - Adieu au mac-mahonisme”, Présence du Cinéma n 24-25, outono de 1967, pp. 101-105. 
Para Lourcelles, o período se mostraria, "por sua pobreza mesma", favorável ao reconhecimento e à revalorização das obras clássicas e, ao mesmo tempo, à "circulação de toda espécie de subproduto atrelado a tendências barrocas e sem maturidade". "Numa programação tão variada e tão confusa, o papel da crítica deveria ser considerável. Ora, ele não é nada” (p. 104). Não é só o cinema que se acha em decadência: a crítica acompanha a descida e perde sua função. Em vez de promover o reencontro com as obras clássicas e acusar a puerilidade dos tais subprodutos de inclinação barroca, a crítica, tal como Lourcelles a vê, louva sistemática e cegamente tudo o que se apresenta, numa atitude acrítica por excelência. Quanto ao mac-mahonismo, este exerceu um papel que ele considera "muito mais vivo e imprevisível" que o da crítica oficial ("sempre na esteira de algo, sempre estupefata, sempre não compreendendo o que estava vendo, mas dando conta longa e inconscientemente daquilo que não compreendia”). Tendo cumprido seu papel, o movimento está apto a se encerrar: "O que era originalidade, paradoxo excessivo, quiçá deplorável maneira de se fazer notar tornouse hoje evidência, simples manifestação de bom senso. Tão melhor assim" (p. 105). Lourcelles faz, por fim, o balanço do mac-mahonismo:

Visto com um pouco de recuo, esse movimento, que sem dúvida nada foi além de um ato de lucidez elementar exercida em um período rico, aparece singularmente ligado a esse período rico (1944-59). Hoje o papel da crítica [...] seria bem diferente. Menos seletivo. Menos espetacular. Mais ingrato. Mais laborioso. Suas características? Só posso mencioná-las brevemente: perscrutar os gêneros anexos, em particular o gênero "fantástico" em sua acepção mais ampla ("mitos e lendas"), único gênero narrativo no momento atual, e que, por essa razão, canaliza o interesse de toda uma parte do público que se viu levada a desistir dos outros grandes gêneros (musical, policial, western), todos em decadência hoje em dia; perceber a partir disso, num momento em que ele parece se desagregar, o edifício compacto do cinema americano cuja coerência se reflete também nas periferias (bas-côtés); avaliar a propósito de diversas empreitadas documentais ou para-documentais o que, nelas, corresponde à essência do cinema nos termos em que Michel Mourlet a descreveu: "ao mesmo tempo o documentário e a feeria", nos termos também em que Fritz Lang entrevia a natureza de seus próximos filmes: sem preocupação estética, brutais e realistas no estilo do cinema de atualidades; enfim, continuar, dentre tantas decepções e mornas sessões, a buscar obstinadamente as linhas de força e a pérola rara; nada saber; nada prever. (LOURCELLES, 1967)

O mac-mahonismo se encerra propondo uma busca ainda mais escrupulosa do belo e do essencial. Mas a mesa redonda sobre Hiroshima Mon Amour e o texto de Rivette sobre Kapò deixariam um legado muito mais "próspero" (em termos da influência que exerceriam 
sobre um grande número de críticos, o exemplo mor sendo Serge Daney ${ }^{117}$ ) que o macmahonismo. Saber identificar o abjeto pareceu mais importante, aos olhos da nova geração de críticos que então surgia, do que compreender as ferramentas do belo - o que diz bastante sobre o estado das coisas nos anos 1960.

\section{Otto Preminger ou O que é a mise en scène?}

Se há um cineasta que, seja nos textos mac-mahonistas, seja nos hitchcockhawksianos, é freqüentemente tomado como exemplo mais acabado do que seria a essência da mise en scène, esse cineasta é Otto Preminger. A partir dos anos 1950, elevado às nuvens pela crítica francesa, ele se torna uma espécie de ponta de lança da definição da essência e da pureza do cinema. A obra inteira do cineasta aparece como um imenso estudo sobre a arte e as diferentes naturezas da mise en scène. Homem de teatro que passou para o cinema, Preminger ilustra de forma magistral a aventura da mise en scène em seu trajeto de migração das artes cênicas para as telas. Ele é encarado como o grande esteta do estilo fluido e transparente que o classicismo exigia:

O estilo de Preminger é, sem dúvida, um dos mais perfeitos que se pode imaginar: designa, a cada instante, o elemento importante da cena e sugere o seu sentido sem ter de o exibir. Compreende-se que este estilo tenha fascinado; com efeito, é difícil ser mais clássico: respeito total pelas convenções, culto da transparência, limpidez do discurso cujo sentido nunca está dissimulado, e representação mais natural possível dos atores. De todos os cineastas de Hollywood da era "clássica", Preminger foi certamente aquele que melhor soube conciliar estes dois condicionalismos contraditórios: fazer sentido e não o mostrar. (AUMONT, 2008)

Basta ver a cena em que a personagem de Gene Tierney, a bela e melancólica Morgan Taylor, é interrogada em Passos na Noite (Where the Sidewalk Ends, 1950): ela está sentada numa cadeira, entre o detetive Dixon (Dana Andrews) e seu parceiro Paul Klein (Bert Freed), que estão de pé. O cenário é pequeno, um escritório bagunçado na loja onde Morgan trabalha, mas isso não impede Preminger de compor uma cena movimentada e dinâmica, apesar de se tratar apenas de um diálogo. Os planos são relativamente longos, os cortes tendo papel mais pragmático do que expressivo. Bert Freed se mexe pouco, tem uma área de ação mais ou menos limitada. Dana Andrews, no começo da cena, afasta-se dos outros dois atores e vem

\footnotetext{
117 Ver "O travelling de Kapò", em DANEY, Serge, Persévérance, Paris: POL, 1994.
} 
para a dianteira do cenário, porém de forma contida, ponderada, provocando reenquandramentos suaves. Já Gene Tierney funciona como o eixo central de tudo: seus deslocamentos são largos e determinantes, implicando reconfigurações na relação câmeraatores-espaço. Sua personagem está sendo interrogada pela morte do marido. Quando Dixon revela que ouviu dizer que o marido costumava espancá-la, ocorre o primeiro corte da cena: de um plano de conjunto que ameaçava se fechar em Dixon, Preminger passa a um plano médio de Morgan, que está com o rosto discretamente alterado pela fala do detetive. Como que tomada por uma agitação momentânea, ela se levanta, vem até a mesa à sua frente e pega um cigarro. A câmera faz um travelling para trás, terminando num novo plano de conjunto, agora com todos de pé. Dixon estende um fósforo aceso a Morgan. Ela acende o cigarro e se dirige ao fundo e à direita do cenário: um travelling para a frente a acompanha, terminando num plano médio com ela e Paul em quadro. Ele continua enchendo-a de perguntas. Dois contra-planos de Dixon no outro canto do cenário se interpõem ao interrogatório. Irritada com as perguntas, Morgan se movimenta de novo e retorna à posição em que estava no início da cena, sendo acompanhada por uma panorâmica à esquerda. Ela senta na cadeira, e estamos de volta ao mesmo enquadramento que deu início a tudo. Após uma série de primeiros planos dos rostos dos três personagens, montados em campo-contracampo, a cena será concluída com um derradeiro retorno ao plano de conjunto que mostra Morgan sentada com os dois homens à sua volta.

O que mais chama a atenção na cena é a quantidade de ações que os atores e, por conseguinte, a câmera executam ${ }^{118}$. Preminger poderia muito bem ter encenado todo o diálogo em planos estáticos. Mas preferiu potencializá-lo por meio de ações corporais que exploram o cenário, mudam as posições dos atores, exprimem variações de humor, induzem movimentos de câmera. Preminger aceitou o desafio da encenação e da dramatização. Como um personagem reage a uma verdade que o incomoda? Como rebate uma pergunta insidiosa? Como dissimula um pensamento por meio de um gesto? Ao se colocar essas questões, o diretor encontra soluções cênicas, constrói o drama. Os movimentos de Gene Tierney desenham um triângulo no cenário, impõem à cena uma geometria precisa. Ainda assim, a mise en scène de seus gestos e movimentos é de uma quase invisibilidade; "uma encenação expressiva - na maior neutralidade aparente" ${ }^{\prime 19}$.

Preminger é, antes de tudo, o homem da fluidez, e o seu instrumento mais importante é o movimento de câmera. Para ele, uma cena é,

118 Outras cenas de outros filmes poderiam ser citadas - algumas bem mais complexas, inclusive (a exemplo da incrível seqüência do julgamento em Santa Joana, de 1957).

119 Aumont, O cinema e a encenação, p. 88. 
antes de tudo, uma continuidade; se a puder filmar num único plano, fá-lo-á, tendo de determinar as trajetórias dos atores de forma a tornar isso possível; se tiver de planificar [découper], recorrerá a ligações [raccords] no movimento; o contracampo não lhe é estranho, mas apenas quando não é evitável e sempre como uma forma neutra que, por si mesma, não tem qualquer expressividade. (AUMONT, 2008)

O uso do plano longo, em Preminger, deve-se à necessidade de tornar a continuidade dramática uma realidade sensível. Ele valoriza a duração da cena, que não pode ser apenas forjada na montagem, mas sim vivida no set, experimentada pelos atores com interrupções mínimas - preocupação natural, em se tratando de um diretor vindo do teatro. O movimento de câmera se torna assim crucial, já que ele muitas vezes pode substituir o corte e a mudança de plano na tarefa de permitir um novo ângulo, uma nova distância, uma nova composição, enfim, um novo acesso à cena. A principal característica dos movimentos de câmera de Preminger é que eles aderem à pele do drama e vice-versa: sua eficácia está em sua transparência; sua beleza, em sua objetividade:

A dramatização busca apreender, e mesmo comprometer, o
personagem em seu cenário. Isso graças a um estilo de movimentos
de câmera: movimentos longos, sinuosos, suaves, ondulantes,
seguindo o personagem em seu cenário, em busca de um equilíbrio
que não visa favorecer nem o personagem nem o cenário. É a vida
do homem em seu cenário, vida captada do exterior - um assalto de
surpresas imediatamente naturais ao olho - que esses movimentos
buscam espreitar e acompanhar, se imobilizando quando a vida se
imobiliza, e mexendo com ela. Seu mistério está em sua precisão.
Seu sucesso está em sua invisibilidade. Eles são ajustados ao
movimento da vida, submetidos a ele, e se recusam a traçar ao redor
dela um arabesco, um balé decorativo pelo qual eles se auto-
valorizariam. (LOURCELLES, 1965)

O crítico e cineasta francês Cédric Anger, na ocasião de uma revisão da obra de Preminger, também se encantará com esses movimentos de câmera "ajustados ao movimento da vida", atentando para o momento em que eles deixam de ser meramente objetivos e passam a ser expressivos, dramáticos:

A beleza clássica da mise en scène de Preminger se deve ao modo de
se contentar, aparentemente, em acompanhar os movimentos de seus
personagens, em observar do exterior e de modo contínuo seus
movimentos no espaço. Inseparável daquele do ator, o movimento
de câmera de Preminger se aproxima docemente do personagem,
mexe e interage com ele antes de reposicioná-lo no espaço e de
abandoná-lo ao continuar seu percurso. Independentemente do 
movimento do herói, esse último movimento de câmera nos faz subitamente abandonar o olhar exterior e realista em favor daquele mais inquietante de um mundo circundante que se fecha sobre os seres e os aprisiona no círculo de sua própria armadilha, de sua maquinação. Primeiramente objetivo, o movimento de câmera muda de natureza no meio do caminho e envelopa inexoravelmente o personagem, interpela-o e depois o abandona como o travelling para frente que deixa a jovem mãe de família de Bunny Lake Is Missing para reenquadrar as máscaras africanas da fecundação que ornam suas paredes ${ }^{120}$.

Cabem aqui alguns comentários sobre esse filme citado por Anger: Bunny Lake Is Missing é o drama de uma mulher, Ann, que acaba de se mudar dos EUA para a Inglaterra e, ao ir buscar sua filha na escola no primeiro dia de aula, constata que a menina desapareceu. Ann notifica o sumiço às autoridades. A questão é que a polícia, uma vez acionada, não consegue encontrar vestígios de que a criança sequer exista, e a integridade psicológica da mãe é colocada em xeque. O filme não mostrou a menina em nenhum momento (mas mostrou o irmão de Ann catando um bichinho de pelúcia no chão já no primeiro plano...), o que se revela menos uma estratégia de suspense (que se conflagraria ao levantar, também no espectador, a dúvida sobre a existência da criança) do que um "teste" para a personagem, para o filme e para o espectador. Para a personagem, o teste pode assim se enunciar: como não se distrair da verdade mesmo em meio ao mais asfixiante complô das falsas aparências e do anuviamento dos fatos. Para o filme: como encontrar o equilíbrio entre uma mise en scène onde cada plano mobiliza uma fortíssima tensão antecipatória do plano seguinte e, no entanto, sabe tanto quanto a personagem, não podendo extravasar o presente das ações, o que implica ainda uma segunda mão de equilíbrio, agora entre manter a objetividade do relato e compartilhar da turbulenta carga emocional da protagonista (desmesurada para quem dela desconfia, justa para quem nela acredita). Ao espectador, cabe não mais que o discernimento; ver o filme, saber aguardar pelo plano seguinte. Aguardar não pela chave do mistério, mas pela beleza da busca.

Bunny Lake Is Missing é a fusão - perfeita - entre duas poderosas frentes da obra de Preminger até aquele momento (1965): uma é a dramatização de uma personagem feminina cujas ações se expõem a todas as falhas, desvios e sobressaltos que advêm dos sentimentos fortes e irrefreáveis (Angel Face e Bom Dia Tristeza nos poupam de indicar quaisquer outros exemplos); a outra é a investigação de um problema (seja um caso de tribunal, uma chantagem política, a amarga vitória de um povo ou o sumiço de uma criança) que será visto

120 Cédric Anger, "Quand Preminger inflammait les mac-mahoniens”, Cahiers du Cinéma no 552, dezembro/2000, p. 67. 
por todos os ângulos, traduzindo-se no que talvez seja o veio de Preminger que mais ficou para a história, que é aquele "de um grande repórter, de um romancista da realidade, apegado sobretudo aos vastos assuntos, aos dramas e às epopéias do mundo contemporâneo"121. Bunny Lake vem após a sucessão de "afrescos coletivos" da primeira metade dos anos 1960 Exodus, Tempestade Sobre Washington, O Cardeal, A Primeira Vitória. Destes, o filme guarda o "realismo documental e analítico", a parcimônia de submeter a câmera às pessoas, aos lugares e à rede de relações lentamente criada. Ao mesmo tempo, ele se volta para uma trama psicológica de curvas sombrias, com cenas no limiar do fantástico (como a da loja de bonecas). "Aparentemente normal e realista, o universo descrito se torna então misterioso, fantasmático e fascinante. O cotidiano se faz sonho ou pesadelo, mundo mental que impede de atingir a verdade." ${ }^{122}$ A mestria de Preminger, nesse filme, é a de ir até a fronteira a partir da qual a atmosfera se interiorizaria por demais e a estilização reinaria e parar um pouco antes, onerando a pressão sobre os personagens sem permitir que o drama se rompa na abstração e no desperdício (pois ele precisa permanecer no real e no concreto, do contrário esse filme não faz sentido). Beirando um certo absurdo, o clímax final no jardim da mansão é um jogo psicanalítico bem calculado, pretexto para um verdadeiro tour de force de mise en scène física.

As gruas e os travellings de Preminger em Bunny Lake elevam a um grau máximo todos os elogios que tantas vezes fizeram por merecer: fluidez, elegância, uma câmera imediatamente sensível aos movimentos dos personagens e do mundo. No entanto, é um corte o que devo comentar aqui. Na verdade, um corte dentro da continuidade. A cena é aquela em que Ann e o superintendente Newhouse (Laurence Olivier), que investiga o caso, conversam num pub: a televisão está ligada e transmite o noticiário; o apresentador começa a falar do desaparecimento da filha de Ann, ao que ela e o superintendente interrompem a conversa e prestam atenção no telejornal. Corta para um plano mais próximo da TV, da qual a câmera chega ainda mais perto, mas o barman troca de canal e passamos a assistir a um show da banda de rock The Zombies. Preminger inscreve na continuidade sensível do plano uma realidade fragmentária, profusa. Brilhante contradição: sua dramaturgia está em algum lugar entre a objetividade jornalística e uma certa vertigem do presente, ou entre o ponto de vista do superintendente Newhouse, o olhar da ponderação, e o de Ann, exasperado, atormentado.

Assistir a um filme de Preminger é perceber o acontecimento simultâneo de todos os elementos implicados na sua construção. Todo e qualquer fator direta e materialmente

\footnotetext{
121 Ver Jacques Lourcelles, "Preminger aujourd'hui", texto presente no catálogo da retrospectiva realizada na Cinemateca Francesa em 1993.

122 Cédric Anger, op. cit., p. 67.
} 
envolvido na dramatização constitui profundamente, elementarmente, primordialmente o objeto de sua arte. Uma concepção pragmática e materialista da cena, o que não significa se fechar às infiltrações de todos os aspectos imateriais e fantasmáticos potencialmente presentes. $\mathrm{O}$ cinema de Preminger se confunde à definição mesma de mise en scène, e não à toa sempre que Jacques Rivette se propunha a escrever um texto sobre ele acabava se deparando com uma nova formulação do que seria a mise en scène:

É na mise en scène que Preminger primeiramente acredita, na criação de um complexo preciso de personagens e de cenários, uma rede de relações, uma arquitetura de relacionamentos, movente e como que suspensa no espaço. [...] Se uma palavra tivesse de definir Preminger, seria efetivamente metteur en scène, ainda que sua experiência cênica pareça aqui pouco influenciá-lo; no seio de um espaço dramático nascido do afrontamento dos homens, ele exploraria antes ao extremo essa faculdade do cinema, de captação do acaso - mas um acaso desejado -, de escritura do acidental - mas um acidental de invenção -, pela proximidade e agudeza do olhar... ${ }^{123}$

E viva Preminger, que sabe que ele não é nem um pensador nem um reformador do mundo, mas simplesmente um perfeito metteur en scène, que nessa expressão há cena, e por que o teatro seria para nós matéria [não] cinematográfica? ${ }^{124}$

A arte da mise en scène é antes uma arte de pôr as coisas no lugar ou no tempo desejados: proporções perfeitas do quadro, arabescos das atitudes, o papel inteiro de Jean Seberg, tudo nos conduz a retomar em minúcia a afirmação final de Bernanos: "Tudo é graça". [...] A invenção que surpreende em cada plano desse filme é antes uma certa genialidade do resumo; a arte do desenhista (e a passagem de Angel Face a Bonjour Tristesse é aquela do esboço ao afresco) é a de saber quais traços são essenciais, quais devem ser acentuados ou eliminados, quais devem ser às vezes inventados do nada para suprir um entrelace confuso; a arte do metteur en scène, de um espetáculo ou de um fato, é saber quais são os elementos indispensáveis ao equilíbrio da figura, ou seja, a cena tal como inscrita em seu lugar definitivo no filme. ${ }^{125}$

Nesses três momentos, portanto, no decorrer dos anos 1950, Rivette buscou compreender o que era o cinema de Preminger consciente de que um tal esforço, se bem sucedido, equivaleria à descoberta do próprio segredo da mise en scène. Falar de Preminger era falar de um "em si”" da mise en scène.

Michel Mourlet, Jacques Serguine e Éric Rohmer, um após o outro, encontrarão essa

123 "L'essentiel", Cahiers du Cinéma no 32, fevereiro de 1954.

124 "En attendant les Godons", Cahiers du Cinéma nº 73, julho de 1957.

125 "Sainte Cécile", Cahiers du Cinéma, no 82, abril de 1958. 
mesma evidência. Mourlet lhe dedica uma breve passagem em "Sobre uma arte ignorada": "O que torna idênticos e quase intercambiáveis - senão no grau da beleza, ao menos no caminho de aproximação da beleza - filmes tão diferentes pela fonte, pela anedota e pelo 'clima' como aqueles que pontuam a carreira de Preminger é um certo modo de olhar os atores e os objetos". Se a obra de Preminger é coerente, não é pela recorrência temática ou pela reiteração de um mesmo universo autoral, mas antes pela mise en scène, que aqui Mourlet traduz como "um certo modo de olhar os atores e os objetos".

Jacques Serguine narra seu primeiro encontro com o cinema de Otto Preminger como um divisor de águas:

\begin{abstract}
Há alguns anos, vi um filme cujo título era $A$ Ladra. É preciso dizer, nada descobri nesse filme. Foi isso, aliás, que me desconcertou; encontra-se sempre alguma coisa. Era o primeiro filme que eu me sentia incapaz de nomear. Nenhum sentido, nenhuma referência. Um homem, uma mulher; eles se mexiam, e seus gestos não exprimiam nada. Eles falavam e as palavras não significavam nada, o filme era pleno de silêncios. Atrás de um vidro fiel, vi silêncios se mexerem; eu estava impelido ao vidro como se costuma se impelir ao que é transparente, ao que é evidente. $\mathrm{O}$ filme era assinado por Preminger.

Por obstinação crítica, vi um ou dois anos depois um filme do mesmo metteur en scène, que se chamava Angel Face. Através dos mesmos silêncios, dos mesmos movimentos aparentemente soltos, percebi alguma coisa. No plano final, um automóvel que atravessava a tela penetrou em mim. O vidro se havia rompido. O que eu tinha pressentido, depois reconhecido no momento em que ela se liberava, era uma tensão vertiginosa, quase imobilizada ao limite dela mesma. Tensão entre uma mulher e um homem, ou ainda, em uma mulher por causa de um homem. Durante um frágil segundo, em seus olhos, vi a alma de Jean Simmons. Creio que ali estremeci. Pela primeira vez sobre a tela, descobri não mais corpos, nem gestos, mas seres. (SERGUINE, 1960)
\end{abstract}

Nessa passagem, percebemos de que modo os mac-mahonianos penaram, num primeiro momento, para definir essa famosa quintessência do estilo que eles amavam tanto no autor de Laura, apelando freqüentemente para evocações subjetivas.

Rohmer, por sua vez, verá Preminger na extremidade oposta de Jean Rouch, mas comungando o mesmo respeito pela natureza: "A técnica de Preminger permite esquecer a intervenção humana e nos aproximar da beleza natural que parece ser sua meta". Para tal, suas ferramentas são a simplicidade do ponto de vista, a "ascese do cenário", a banalidade das atitudes: "a câmera, sempre presente no momento desejado, sempre lá onde deve estar, se instala no coração das coisas e, por essa exatidão, devolve-as à natureza, qualquer que seja o 
artifício que presidiu sua mise en place. [...] Essas pequenas belezas são a grande arte; nós a admitimos na pintura, por que não no cinema?"'126. Naturalidade, espontaneidade, essencialismo, serenidade, nobreza: essas seriam, aos olhos de Rohmer, as grandes virtudes de Preminger:

\begin{abstract}
Podemos nos contentar de ver em Preminger - e é motivo de admiração suficiente - um dos mais puros representantes de um cinema clássico, goethiano, se podemos dizê-lo, por essa espécie de serenidade sem afobação de que constituiu o olhar, esse desprezo pelo bizarro, esse culto dos grandes lugares comuns, essa busca do essencial, do ato em sua plenitude, esse amor pela ordem, pela organização, esse gosto pelos seres excepcionais, e portanto vulneráveis, mais próximos dessas "linhagens de rei" caras a Gobineau do que do modelo romântico. Podemos destacar a que ponto a nobre simplicidade de seu estilo se furta à analise, porque cada problema particular é resolvido em função de um sensibilidade sempre à espreita, não de um sistema altamente clarinado. (ROHMER, 1961)
\end{abstract}

Jacques Lourcelles trará a “fórmula definitiva” em seu livro sobre Preminger:

Sobre o papel, toda cena escrita se reduz forçosamente a uma sucessão de idéias, de detalhes, de tratos mais ou menos engenhosos e abundantes. Sobre a tela, contrariamente, convém que esses detalhes não apareçam mais enquanto tais, enquanto efeitos isolados, mas que eles estejam todos fundidos no corpo e no tempo da narrativa. A melhor mise en scène possível é evidentemente aquela que é a mais desprovida de "idéias de mise en scène" [...] Ora, é a adesão estrita do cenário à ação que permite uma melhor absorção harmoniosa desses detalhes significativos por uma narrativa que saiba articulá-los em silêncio, sem maneiramento e sem ruptura. Ao grau dessa absorção, é preciso julgar a qualidade de uma mise en scène. (LOURCELLES, 1965, pp. 21-22)

No lugar de dizer “o cinema de Otto Preminger”, portanto, podemos simplesmente dizer: eis o que é a mise en scène, afinal.

126 Rohmer, "Le goût de la beauté”, originalmente em Cahiers du Cinéma nº 121, julho de 1961. 
II.

Onde está a mise en scène? 


\section{Do maneirismo ao "fim da mise en scène"}

Em abril de 1985, os Cahiers du Cinéma publicam um dossiê intitulado "Le cinéma à l'heure du maniérisme", condensando a hipótese que já vinha sendo esboçada em edições anteriores da revista: a de que, analogamente ao que ocorrera nas artes plásticas após o fim do Renascimento, o cinema vivia um "momento maneirista". O artigo que faz um apanhado geral da questão é o de Alain Bergala, "D'une certaine manière", que começa apresentando o conceito em sua amplitude, uma vez que abrange filmes que derivam de sensibilidades e anseios bastante distintos entre si. O que Paris-Texas (Wim Wenders, 1984), Estranhos no Paraíso (Stranger than Paradise, Jim Jarmusch, 1984), O Elemento do Crime (Forbrydelsens element, Lars Von Trier, 1984), Boy Meets Girl (Leos Carax, 1984) e L'Enfant secret (Philippe Garrel, 1979) possuem em comum, por mais singulares que sejam suas propostas estéticas, é a consciência de ter chegado depois: assim como a perfeição da forma clássica já tinha sido atingida e superada havia muito tempo, a energia e a criatividade do cinema moderno se tinham igualmente esgotado ao longo dos anos 1970. A forma que resulta dessa constatação, portanto, é uma forma tardia, e, enquanto tal, traz em si o peso da idade avançada do cinema. Peso que pode se manifestar como uma dificuldade (em última análise, dificuldade de inventar e rodar um único plano) perante a qual "cada um procura sua resposta, infeliz ou arrogante, mas numa relativa solidão em relação a seus contemporâneos na criação cinematográfica". Tomando o Maneirismo histórico como referência, Bergala esclarece esse sentimento comum aos maneiristas:

[O Maneirismo] se caracteriza pelo sentimento que tiveram pintores como Pontormo ou Parmigianino de chegarem "tarde demais", depois que um ciclo da história de sua arte tinha sido completado e uma certa perfeição atingida pelos mestres que lhes tinham precedido de perto como Michelangelo ou Rafael, a "Maneira" se constituindo como uma das respostas possíveis (com o Academicismo e o Barroco) a esse esmagador passado próximo. "O maneirismo", escreve Patrick Mauriès, "se situaria, desde a origem, à beira, no limite de uma 'maturidade' que teria concretizado todas as suas potências, queimado seus estoques secretos". (BERGALA, 1985)

No caso específico do cinema, das muitas "maneiras" que se apresentam com mais clareza ali no começo da década de 1980, há duas atitudes principais a se observar: a sobrecarga e o retraimento. De um lado, a tensão formal, a hipérbole, a distorção, a anamorfose, a arte fambloyante, vertiginosa, a narrativa em torvelinho (Von Trier, De Palma, 
Raoul Ruiz). Do outro, o formalismo desafectado, a imobilidade, a duração extenuante, a lentidão, o enredo desdramatizado, a narrativa rarefeita (Wenders, Jarmusch). Em ambos, a "Maneira" como resposta a um sentimento misto de soberania e precariedade face à realidade e à consciência de que o cinema não é mais "inocente".

O maneirismo, para Bergala, cristaliza-se com o fim do cinema moderno, na virada dos anos 1970-80. Mas já haveria um espírito maneirista rondando o cinema desde os primeiros filmes de Orson Welles. Ou ainda: desde Eisenstein (citado na mesa redonda realizada entre a redação dos Cahiers e o historiador de arte Patrick Mauriès ${ }^{127}$ ).

\begin{abstract}
Nenhuma dúvida de que já houvesse, em todas as épocas da história do cinema, temperamentos maneiristas e que seria de fato esclarecedor desenvolver um dia esse fio do maneirismo, na tessitura serrada da história do cinema em que ele se encontra ainda bem dissimulado. (BERGALA, 1985)
\end{abstract}

À guisa de traçar a história completa do maneirismo no cinema, seria preciso recorrer ao paradoxo de tratá-lo como tendência estética trans-histórica, como pulsão formal que pode se manifestar em qualquer época e em qualquer contexto no qual um cineasta invista nas "maneiras". A noção de maneirismo "não permite nem circunscrever um período preciso da história do cinema nem desenhar os contornos de um movimento estético" ${ }^{128}$. Por isso mesmo, não depende exclusivamente do sentimento de "ter vindo depois e ter por tarefa necessária e primordial situar-se em relação a um modelo inultrapassável, com o objetivo de trabalhá-lo ou até mesmo destruí-lo"129. Trata-se antes de "uma atitude estética que podemos encontrar em todas as formas artísticas, desde que o artista concentre sua atenção, sua reflexão e esforço sobre a técnica e a tecnicidade, com o fito de atingir a expressão e produzir a emoção estética pelo singular uso que ele faz da técnica consubstancial à sua arte" ${ }^{\text {130. }}$.

No cinema, o maneirismo engendra diferentes níveis. Num primeiro nível, trata-se da variação de uma estrutura anterior, modificando e agrupando de outro modo as formas plásticas como tais: o cineasta se sente impelido, por exemplo, a dilatar ou acelerar um pouco mais a duração, retardar ou antecipar o contraplano, substituir uma decupagem simples por um plano-seqüência tour de force, mudar o tom (das cores, das luzes), fermentar ou introverter as performances dos atores (pensar em Welles ou no classicismo tardio de Anthony

\footnotetext{
127 "Le cinéma, l'art et la manière", Cahiers du Cinéma n ${ }^{\circ}$ 370, abril de 1985.

${ }^{128}$ V. Campan e G. Menegaldo, "Avant propos", em La Licorne no 66.

${ }^{129}$ Cf. Fabien Boully, "A lentidão de Deus: maneiras e maneirismo na Comédia de Deus de João César Monteiro", em La Licorne $\mathrm{n}^{\circ} 66$ (traduzido do francês por Luiz Soares Júnior e publicado em seu blog "Dicionários de Cinema").

${ }^{130}$ Idem.
} 
Mann e Robert Aldrich ${ }^{131}$ ). Num segundo nível, ao recuperar certos gêneros num momento em que eles já não dialogam com o público "inocentemente", o cineasta precisa refratar a luz por meio de um material mais carregado, mais opaco, portanto menos poroso e menos transparente do que nos filmes clássicos (os faroestes crepusculares de Clint Eastwood, seus auto-retratos frontais e sombrios ${ }^{132}$ ). Num terceiro nível, a "maneira" é um efeito engenhoso obtido através de algo construído com consciência e habilidade, e o cineasta se entrega a toda uma reengenharia cinemática - o real se esfacela e sua representação implica uma abstração da forma precedente, uma certa independência quanto às leis orgânicas que a sustentavam (a vertiginosa fermentação do artifício em Trágica Obsessão, Dublê de Corpo ou Síndrome de Caim, de Brian De Palma). Num quarto nível, as ligações já se fazem mais problemáticas, surge um ruído na passagem de um plano a outro, ou mesmo no interior de uma composição o plano se povoa de elementos problemáticos da visão e esses problemas se tornam inclusive o ponto de partida da ficção (as composições saturadas, ou “decomposições”, em La Ville des Pirates e Genealogias de um Crime de Raoul Ruiz). E assim vai, até o ponto em que o cineasta precisa compensar, pela complexidade da técnica, a dificuldade em lidar com sua herança formal, como faz Wim Wenders em Paris-Texas através de um intricado dispositivo especular (os jogos de espelhos são uma característica eminentemente maneirista):

131 Nos Estados Unidos, uma primeira vertente maneirista aparece já nos anos 1950, associada a uma geração de diretores - a de Robert Aldrich e Anthony Mann, entre outros - que trabalham ainda com os mesmos materiais e os mesmos gêneros (o western, o noir, o filme de guerra etc) da antiga Hollywood, porém aportando-lhes uma nova sensibilidade, uma maneira pessoal de representar um mundo que já não consegue esconder seus desconcertos, suas desarmonias, não consegue conciliar tão bem seus conflitos internos. A questão é menos de contestar os códigos do que de submetê-los aos limites de sua capacidade de significação. Quando Anthony Mann retoma os temas e os cenários favoritos de John Ford, nota-se, por exemplo, que as amplas paisagens naturais atravessadas pelos heróis se tingem de cores mais ruidosas, metálicas, do mesmo modo que a noção de comunidade e o esforço para sua manutenção são abordados por um ângulo mais agudo, mais percuciente. Há, sobretudo, uma mudança no traço, na composição: no clímax de um filme como Bend of the River (1952), as reações do herói às situações de perigo ressaem de maneira mais enfática na decupagem, e demoram um pouco mais, como se Mann alongasse a performance física do ator (multiplicando também suas vacilações e dúvidas); em The Naked Spur (1953), uma rápida panorâmica que vai de um personagem a outro no momento do confronto se substitui ao que na estrutura tradicional do duelo seria resolvido por um campo-contracampo. Mann age à semelhança de um dos precursores do Maneirismo histórico, o Parmigianino, que pintava o pescoço da Virgem um tanto mais longo do que Rafael o teria pintado e utilizava outros parâmetros de equilíbrio e arranjo das figuras no quadro. Em alguns filmes de Aldrich, por sua vez, percebe-se uma crescente anamorfização das figuras do noir (Kiss me deadly, O que terá acontecido a Baby Jane?, Com a maldade na alma), do western (Vera Cruz, Apache) ou do filme de gangster (The Grisson Gang); de efeitos de iluminação e cenário a trabalho de atores e construção da trama, tudo em seus filmes sofre de uma espécie de sobrecarga, um estetismo agressivo e extremo.

132 A cada filme, a cada reimpressão de sua persona, Eastwood se mostra o suporte de sua própria aparição, o corpo que receberá o fantasma de si mesmo (num verdadeiro curto-circuito da luz). Toda vez que se filma como ator, a tarefa de Eastwood é fazer retornar uma figura do passado; seu rosto é a superfície que hospeda desde sempre a mesma imagem. Essa superfície vem mudando de textura, ganhando rugas, criando vincos, salientando cicatrizes. A mudança não se acha na imagem projetada, mas antes no seu local de projeção. Ele trabalha ainda com a luz retilínea do classicismo; a superfície em que essa luz incide, no entanto, não a absorve completamente, criando áreas densas de sombra no rosto do ator-diretor. O espelho de Eastwood é como o espelho maneirista do famoso auto-retrato côncavo de Parmigianino: a anamorfose está em seu suporte, mais do que no traço em si. 


\begin{abstract}
Wenders inventa para si mesmo um dispositivo bastante complicado de vidro e de telefone para chegar a simplesmente filmar um campocontracampo entre um homem e uma mulher como o cinema americano dos anos 50 fazia uma dúzia a cada doze vezes, mas ele tem necessidade dessa prótese para reencontrar a figura mais "natural" do cinema clássico. (BERGALA, 1985)
\end{abstract}

A famosa cena do diálogo no "peep-show" de Paris-Texas resulta do enorme esforço de Wenders para se desembaraçar de seu excesso de consciência e de conhecimento a respeito do passado glorioso do cinema. "A focalização em uma dificuldade parcial em se igualar aos mestres ou ao cinema do passado culmina muitas vezes numa hipertrofia maneirista no tratamento desse traço particular” (Bergala). Diante da dificuldade de enquadrar e decupar uma cena, Wenders reage com uma valorização hipertrofiada do quadro e do dispositivo cênico como um todo.

Envoltos na atmosfera do maneirismo, uns recorrem a um olhar nostálgico para o passado clássico, enquanto outros sentem uma verdadeira impossibilidade de reproduzir sua linguagem. Certas ligações entre planos, certos movimentos, certas operações responsáveis pela unidade da cadeia significante, que no discurso transparente da narrativa clássica estavam embutidos na forma e criavam-se espontânea e naturalmente, agora já não são possíveis senão ao custo de sua disfunção ou esgarçamento. Lá onde a decupagem clássica havia construído um sistema formal sólido e eficaz, com cimentos internos que tornavam automáticos os raccords, instaura-se então um vazio ou, seu contrário, um excesso.

O maneirismo envolve portanto uma idéia de crise - crise de temas, motivos, formas, mas sobretudo crise dessas articulações, desses ligantes outrora naturais, agora disfuncionais nuns casos e hipertrofiados em outros.

Por isso a Nouvelle Vague, cuja cinefilia crítica e cujo conhecimento teórico sobre as obras de grandes mestres não resultaram num modelo paralisante, escapou de ser a primeira geração maneirista do cinema francês, embora historicamente fizesse todo sentido que fosse, pela série de razões que Bergala enumera:

Inicialmente porque a Nouvelle Vague foi a primeira geração de cineastas cinéfilos. Em seguida porque ela apareceu no final dos anos 50, ou seja, precisamente no fim dessa "maturidade" que constituiu para o cinema sua era clássica, no momento do abandono dos gêneros e da pulverização do público de massa pela televisão. Enfim, porque antes de realizarem seus primeiros filmes, quando eles eram críticos, os futuros cineastas da Nouvelle Vague escolheram mestres difíceis de superar. Hitchcock poderia ter sido o Michelangelo deles, e Hawks, seu Rafael. Mas essa admiração dos 
Mestres, curiosamente, não agiu sobre eles como consciência de um passado esmagador que os teria levado a ser os maneiristas dessa excelência, por eles teorizada, de um Hitchcock ou de um Renoir. (BERGALA, 1985)

Ao filmar de modo quase instintivo, os cineastas da Nouvelle Vague afastavam para longe qualquer idéia de crise. Eles filmavam com um frescor, uma jovialidade e um despojamento que pouco têm a ver com a arte maneirista, atormentada, angustiada e tenebrosa por natureza (ou então simplesmente "afetada", como é muitas vezes o caso no "maneirismo amaneirado"133). É somente mais de vinte anos depois de Acossado que Godard vai se deparar com o maneirismo, em filmes como Passion, Detetive, Prenom Carmen ou Je vous salue Marie, quando até mesmo filmar um pôr-do-sol ou o rosto de uma bela jovem (como ele filmava aos montes nos anos 1960) se torna um suplício, pois a imagem perdeu sua inocência e a beleza, antes um dom natural do cinema, agora só se conquista ao cabo de muito sacrifício (a atriz de Je vous salue Marie se contorce na cama como se materializasse o esforço necessário para achar o ângulo, o quadro, a luz, o caminho tortuoso que, em 1985, diferentemente da frontalidade dos planos de Anna Karina em Uma mulher é uma mulher [1961] ou Viver a vida [1962], apresenta-se a Godard como o único caminho possível para a beleza que procura).

Além do instinto natural com que filmavam, e da "impaciência que os conduziu a fazer seus primeiros filmes numa economia de pobreza, à margem do cinema convencional da época", os cineastas da Nouvelle Vague tiveram, naquele momento, "a sabedoria intuitiva de darem a si mesmos mestres quase antinômicos":

Do lado da demiurgia, os cineastas da Nouvelle Vague escolheram Hitchcock e do lado da concretização de um cinema de gênero Hawks, ou seja, nos dois casos, um ideal cinematograficamente muito distante e inimitável na França, onde eles iam filmar seus primeiros projetos. No cinema europeu próximo, inversamente, eles deram a si mesmos os mestres mais liberadores possíveis, Renoir e Rossellini, contra o academicismo triunfante que representava aos olhos deles o cinema de qualidade francesa da época. Pode-se dizer que a admiração deles por Rossellini serviu objetivamente de antídoto àquela, que poderia ter sido bem mais paralisante, que eles tinham simultaneamente pelo inigualável domínio hitchcockiano. (BERGALA, 1985)

As próprias condições materiais em que foi gerada a Nouvelle Vague contribuíram diretamente para o surgimento de novos motivos e temas:

133 Ver Boully, op. cit. 
Privados do sistema de estúdios e de estrelas ao qual eles não tinham acesso, eles se encontraram, por necessidade, novos motivos (os cenários naturais, a rua, novos atores), e por gosto, novos temas. Eles se encontraram um pouco na situação dos pintores que saíam pela primeira vez de seu ateliê e descobriam novos motivos ao invés de procurá-los no Museu, nos quadros admirados de seus ilustres predecessores. (BERGALA, 1985)

Em paralelo à Nouvelle Vague, já havia Jean-Pierre Melville, que transformava o thriller policial em arte abstrata ao congelar seus signos em narrativas lentas, silenciosas, de uma "melancolia saturnina" 134 , habitadas por figuras descarnadas, dotadas de certo "erotismo glacial". Os objetos de cena e os figurinos pareciam coleções de fetiches do cinema noir; a decupagem se proliferava em detalhes e dilatava as ações em seus interstícios e sobras: uma arte maneirista em numerosos aspectos. Mas Melville era um caso isolado. O "momento maneirista" propriamente dito só chegaria na França vinte anos depois, quando o imaginário do cinema já se apresentasse como uma imensa massa de signos, "uma confusão dos estilos e dos modelos".

Tal confusão não se restringe, evidentemente, à França, e se expressa de forma sintomática na relação que cineastas de todos os cantos do mundo estabelecem com o cinema americano, cuja vasta iconografia serve de modelo para uma série de filmes nos anos setenta e oitenta, sem que os realizadores se mostrem, todavia, herdeiros de um mesmo passado: cada um pode escolher para si o momento, o gênero e eventualmente os mestres "aos quais pretende se apoiar ou medir sua empresa criativa".

Para Brian De Palma ${ }^{135}$, por exemplo, o modelo será o suspense hitchcockiano, que ele começará a trabalhar mais incisivamente a partir de Irmãs Diabólicas (Sisters, 1973) e, sobretudo, Trágica Obsessão (Obsession, 1975). Neste último, o enredo é praticamente todo decalcado de Vertigo. O prólogo, inclusive, se passa em 1959, ano de lançamento do filme de Hitchcock. O protagonista de Trágica Obsessão, Michael, perde a esposa Elizabeth e a filha Amy num seqüestro que termina em tragédia. Michael se sente culpado pelas mortes, que foram precipitadas pelo plano fracassado do qual ele aceitara participar para capturar os bandidos sem entregar o dinheiro do resgate. Dezesseis anos depois, em 1975, ele viaja a Florença, o berço do Renascimento ${ }^{136}$. Lá, na famosa igreja de Santa Maria Novella,

${ }^{134}$ Cf. Gustav Hocke, Maneirismo: o mundo como labirinto, São Paulo: Perspectiva/Edusp, 1974.

135 Que não chega a ser mencionado no texto de Bergala, mas é um nome essencial quando o assunto é maneirismo no cinema.

136 O filme não vai a Florença à toa: De Palma explicitamente remete sua releitura de Hitchcock à oposição classicismo/maneirismo que se desenvolve no Renascimento tardio. 
exatamente no mesmo lugar onde conhecera Elizabeth muitos anos antes, Michael avista Sandra, uma jovem mulher que é idêntica a sua falecida esposa. Ele a conhece, se apaixona e a leva para os EUA. Sandra também será seqüestrada, e Michael - mais uma vez confrontado à situação inicial do filme - tentará refazer o desenho do destino, livrar-se da culpa, corrigir as imperfeições e os erros que, no passado, resultaram na morte de sua esposa e, supostamente ${ }^{137}$, de sua filha.

Na primeira cena em que Sandra (interpretada por Geneviève Bujold, a mesma atriz que faz Elizabeth) aparece para Michael, ela está no alto de um andaime montado no interior da igreja, onde trabalha na restauração do afresco de uma Madonna pintada em 1328 por Bernardo Daddi. O lugar elevado onde ela se encontra funciona de certo modo como um palco, e desde já suas ações se tomam por representações. No primeiro diálogo que travam, ela explica que uma infiltração danificou partes da pintura que está a restaurar e revelou, por trás desta, uma outra imagem da Madonna, anterior, mais antiga, talvez uma pintura totalmente diferente, talvez um esboço do pintor para essa mesma obra, não se sabe ao certo. Entre desvendar o mistério da pintura anterior e preservar a beleza da pintura mais recente, os restauradores ficaram com a segunda opção. "O que é belo deve ser preservado", concorda Michael. A cena resume não só o enredo (Sandra, à semelhança da Virgem pintada na igreja, é também uma imagem que veio depois, e sob a qual jaz uma imagem precedente, sendo que Michael não quer investigar o enigma dessa semelhança, quer apenas desfrutá-la), mas principalmente a lógica de criação do filme: a representação maneirista como um efeito de dupla visão, de sobre-impressão de duas imagens numa só, de modo que se possa ver na projeção presente, como nas porções deterioradas do afresco, a imagem que veio antes, a imagem que obceca.

Michael quer ver em Sandra a imagem projetada de seu desejo, sua aventura consistindo em tentar obter uma imagem ideal a partir dessa substância impura que é o corpo. Ele deve remodelar, no material de que dispõe, as partes que não correspondem ainda à Idéia; essa etapa é necessária para que ele chegue ao desenho perfeito guardado no espírito, aquele “desenho interior" cuja transposição ao mundo sensível exige a reparação da disposição

137 Quem viu o filme sabe que Sandra se revela, na parte final, a filha de Michael, que não havia morrido e fora mandada para Florença por seu sócio Bob, que é o grande vilão. Ela crescera achando que o pai era o responsável pela morte da mãe, e por isso topara o plano de Bob (movido por interesses financeiros) de se passar por uma desconhecida jovem italiana para seduzir Michael e se vingar dele. Essa bizarra reviravolta que revela Sandra como a filha de Michael já adulta demonstra, por si só, o fracasso dele em sua tentativa de reverter o destino. O erro de Michael é o mesmo cometido por Scottie (James Stewart) em Vertigo: no intuito de salvar o Plano divino que uma ameaça tenebrosa parece querer destruir, o herói se torna o executor inconsciente desse contra-plano diabólico que julgava combater. 
viciosa da matéria e dos erros das aparências naturais ${ }^{138}$. Numa conversa, Sandra pergunta como era Elizabeth. "Muito parecida com você”, diz Michael, "mas ela andava de um jeito bem diferente". "Diferente como?", Sandra pergunta. Ele sugere que ela suba as escadas logo à frente, e começa a corrigi-la, pedindo que deslize de maneira mais suave, mais "clássica". Michael estará, desde então, empenhado em fabricar uma mulher a partir de outra, assim como De Palma fabrica um filme a partir de outro. Ambos ousam rivalizar com a obra original (do destino, da natureza, da criação divina, da criação artística), ousam crer na possibilidade de, mediante um método persuasivo, buscar o aperfeiçoamento dessa obra. Não custa lembrar que a teoria da arte no período maneirista distingue expressamente o ato de "retratar", que reproduz a realidade tal como se vê, e o ato de "imitar", que a reproduz tal como se deveria vê-la. De Palma, em sua assumida posição de imitador, reivindica uma grande liberdade não só do imitador em relação ao objeto imitado, como também do artifício em relação aos códigos da representação naturalista (é emblemática a cena em que, para mostrar um flash-back da infância de Sandra/Amy, De Palma utiliza a própria Geneviève Bujold no papel da criança, causando um enorme estranhamento). Ele parte de uma realidade que já é, em si, superfície icônica, reino da imagem que é puro prazer e gozo estético. Mas todo prazer, quando ultrapassados certos limites, descamba em sua negação, o desprazer: não fica claro se Michael e sua filha chegaram a ter uma relação sexual, mas a simples dúvida que se instaura, aliada ao fato de que, independentemente do sexo, eles conviveram como amantes, é suficiente para plantar o terror e o mal-estar no abraço final de reconciliação, quando ela o chama de "papai" em meio a um delirante e infindável travelling circular que vislumbra o êxtase romântico à mesma medida que afirma o despertar doloroso da consciência - a cisão traumática do passado interfere no mundo onírico da iconicidade e da referencialidade e o perturba profundamente.

De Palma deliberadamente se inscreve em "um jogo de relação entre uma obra originária e uma obra segunda, obra esta que opera, a partir da primeira, um trabalho de distorção, de exageração e de deformação figurativa" "139. Sua anamorfose, na verdade, extrapola o plano figurativo, pois inclui também uma distorção grotesca da trama. Existe aquela fórmula de Marx lembrada por Stéphane Delorme num texto sobre Redacted $^{140}$ : a história se repete, a primeira vez como tragédia, a segunda como farsa. A tragédia luciferiana $^{141}$ do inesquecível detetive Scottie, portanto, só podia se repetir como farsa (uma

\footnotetext{
${ }^{138}$ Cf. Panofsky, Idea: a evolução do conceito do Belo, 2a ed. São Paulo: Martins Fontes, 2000.

139 F. Boully, op. cit.

140 "Farce attaque", em Cahiers du Cinéma $\mathrm{n}^{\circ}$ 631, fevereiro de 2008.

141 Ver Jean Douchet, Hitchcock, Paris: Ed. Cahiers du Cinéma, 1999, 2006.
} 
farsa edipiana, por assim dizer), e De Palma leva isso às últimas conseqüências em sua releitura de Vertigo.

Lars Von Trier, por sua vez, terá como modelo o barroco wellesiano. Em O Elemento do Crime (1984), ele elabora uma narrativa tão retorcida sobre si mesma que a própria noção de ponto de vista passa por uma mise en abîme completa. O desejo de ultrapassar o caos da matéria e chegar ao segredo que está por trás da perfeição da forma o conduz a uma única e incontornável conclusão: no fundo das coisas, no cerne da mente criadora de tudo, há o vazio. O filme é uma perplexa contemplação desse vazio. Fisher, o protagonista, luta inutilmente para decifrar o caos, compreender a mente do assassino em série, ter acesso ao plano magistral, ao desenho sublime, ao segredo do mastermind, ao "elemento do crime" sobre o qual o professor Osborne discorre em uma conferência a que ele assiste repetidamente num pequeno monitor. Ele é o representante de Von Trier na diegese: um olhar que mergulha no assombroso universo wellesiano somente para se deparar, mais de quarenta anos depois de Cidadão Kane, com um labirinto de signos em que a significação é justamente aquilo que se perdeu. A fotografia adquire um tom estranhamente estilizado, não é o preto-e-branco da reverência ao passado, nem o colorido histérico do presente adoecido, mas uma espécie de monocromia agonizante, um bronze pomposo e atormentado ao mesmo tempo. O som cria uma certa dissociação entre as vozes e os corpos: as vozes, assim como o olhar implicado na mise en scène, vêm de longe, do espaço dos mortos, e portanto chegam ao filme com um eco esquisito, um timbre diferente.

Jim Jarmusch já seria herdeiro de um outro momento. A saturação e o excesso, em seu cinema, desembocam na banalidade, na falta de trama, na perambulação vagabunda de personagens cujo único território é o próprio corpo. Permanent Vacation (1980), seu filme de estréia, é composto de longos hiatos deambulatórios, de personagens sem espessura psicológica, de cenas sem contorno dramático. Partindo do espaço desconectado e esvaziado que ele herdou do cinema moderno, o filme é um passeio por ruínas e becos, conduzido por um jovem sem rumo, de visual bebop anacrônico. A estilização é questão de gestual, de poses, de estases gráficas - um self-service de referências tiradas do cinema moderno, da cultura pop, da arte de vanguarda etc.

No segmento final de seu texto, Bergala aborda essa questão do self-service de signos e chega à descrição de um tipo de maneirismo que, no momento em que escreve, é uma novidade:

Os anos 80 terão visto surgir uma nova espécie de produtos cinematográficos, sobretudo do lado das "novas imagens", que 
derivariam de um maneirismo de outra natureza, um tipo de maneirismo à revelia. Desejo me referir a esses cineastas para quem o cinema não tem nem mais Mestres nem mais História, mas se apresenta como uma grande reserva confusa de formas, de motivos e de mitos inertes da qual eles podem beber com toda a "inocência" cultural, ao acaso de suas fantasias ou modas, para sua empresa de reciclagem de 90 anos de imaginário cinematográfico. Essa visão do passado do cinema que consiste em fazer não tábula rasa mas um self-service deve muito, sem dúvida, à difusão televisiva, onde todos os filmes perdem de uma certa forma sua origem histórica e sua relação com um cineasta singular. [...] A televisão, a seu jeito, esvazia identicamente os filmes de todo "imaginário de Verdade", os desconecta de toda origem, e os retira toda aura singular. É provável que ela tenha contribuído para transformar a consciência do passado do cinema, a partir de onde pôde nascer um verdadeiro maneirismo, como simples reservatório de motivos e de imagens de onde está para nascer uma forma degradada e obtusa de maneirismo maneirado. Mas isso enceta talvez uma outra história, a história da reciclagem generalizada do cinema... (BERGALA, 1985)

O texto se encerra com reticências. O destino do cinema dali para frente é indeterminável, está absolutamente em aberto. A pauta dos Cahiers du Cinéma dedicada ao maneirismo pertence, na visão de Jacques Aumont, a um momento de incerteza. De um lado, decreta-se o fim do moderno; do outro, lamenta-se a distância irremediável do classicismo. Época de melancolia e profecias, de luto (fala-se da morte do cinema), de vitória da publicidade como estrutura de produção e estética dominantes. Época também da reciclagem, do pastiche, das reprises de todo tipo. "O 'maneirista' sofre de uma memória que ele não consegue enterrar" (Jean-Baptiste Thoret ${ }^{142}$ ). Dez anos depois da edição dos Cahiers sobre o maneirismo, a revista $A u$ hazard Balthazar, criada por Stéphane Delorme, hoje editor dos Cahiers, consagra um número à mesma noção, constatando que "ela muda de sentido segundo os textos e só acha sua coerência ao ser sistematizada de modo brutal na tríade classicismo/modernismo/maneirismo"143. Ou seja, por mais que se tenham realizado estudos aprofundados e rigorosos acerca do maneirismo, o conceito, uma vez aplicado ao cinema, deixa sempre uma ponta de imprecisão.

Como nos lembra Aumont, "maneirismo" não foi o único termo convocado a descrever o momento atravessado pelo cinema nos anos 1980, “década de confusão, na qual os filmes derrotam as categorias e, em reação, a crítica inventa diariamente novas categorias, se agarrando como pode aos ramos da velha história da arte": surgiram também barroquismo, neobarroquismo e outras nomenclaturas mais.

142 "D'un Psycho à l'autre, l'original n'a pas eu lieu: le mythe de l'original et la (presque) fin du 'maniérisme'”, em La Licorne $\mathrm{n}^{\circ}$ 66, p. 62.

${ }^{143}$ Citado por Aumont em Moderne?, Paris: Ed. Cahiers du Cinéma, 2007, p. 83. 
Em todo caso, a característica mais patente do cinema dos anos oitenta e ainda noventa é o extremismo, a tendência ao sobre-. Sobre-sensação, das violências cultivadas por Peckinpah, Siegel ou Penn ao fenômeno de massa mais importante dos anos oitenta, a emergência do cinema de Hong Kong. Sobre-citação, de Syberberg e seu caldo de cultura ao Godard asfixiado de referências dos anos noventa em diante, mas também, de maneira mais lúdica e mais inesperada, a cineastas como Gus Van Sant, Todd Haynes ou Aki Kaurismaki. Sobre-imagem, com os desencadeamentos do artifício, digital ou não; vide o bullet time, invenção extraordinária (que obriga a reler de outra forma o uso de um instrumento formal como o zoom). Sobre-dramaturgia, nos neo-autores de Hollywood, de Ferrara a Lynch passando por Verhoeven e até Michael Mann. (AUMONT, 2007)

Entre os anos 1970 e os 2000, assim sendo, ter-se-ia testemunhado a aparição de diversas vertentes de um sobre-cinema, ou de um hiper-cinema, ou ainda de um "cinema filmado" $" 144$.

Paralelamente ao surgimento de tudo isso, Hou Hsiao-hsien realiza seus primeiros filmes, ali na virada da década de setenta para a de oitenta. Há nostalgia? Sim, mas não é nostalgia do passado do cinema. É a nostalgia de alguma experiência vivida, de algum episódio da juventude do diretor. Ou então a nostalgia do presente, do instante que passa e não volta. A mise en scène de Hou é a escritura dessa efemeridade, e se constrói pela captura de toda forma de movimento presente no mundo (trem, moto, carro, pessoas). O mundo se torna visível por meio do movimento, e este se faz, assim, não apenas um elemento estético, mas uma verdadeira forma de conhecimento. Já em seus primeiros longas, sobretudo em The Boys from Fengkuei (1983), Hou parece se situar na extremidade de toda uma idéia moderna do cinema que repousa sobre o uso recorrente do plano geral, da profundidade de campo, do fora-de-campo, da redução narrativa, da abertura para o mundo, da permeabilidade a tudo que "não pertence" ao filme. Aquele barroco (Von Trier) e aquela vacância (Jarmusch) que derivavam da dissecção da forma clássica e/ou do tédio pós-moderno são assuntos estrangeiros à estética de Hou, cuja modernidade se define por seu "primitivismo": ele troca o quadro pelo campo (notar a diferença: o quadro é um retângulo de imagem completo em si mesmo, enquanto o campo é um fragmento volúvel do mundo ${ }^{145}$ ), a cronologia pela duração, as grandes rupturas narrativas pela discreta sucessão de pequenos "nadas".

Enquanto para muitos cineastas não há mais mise en scène inocente, e todo o exercício

${ }^{144}$ A expressão é de Jean-Claude Biette, que a utiliza já nos anos 1970 para designar o lado mais maneirista de Fassbinder.

${ }^{145}$ Voltaremos ao assunto, em detalhes, mais adiante. 
de encenação deve ser deliberado, refletido, consciente do seu lugar na história das formas, outros, como Hou Hsiao-hsien, filmam como se o cinema tivesse acabado de ser inventado. Esta segunda via é a da "captura aleatória de aparências mutáveis, da invenção de dispositivos que dispensam a mise en scène no sentido técnico", via inaugurada por Rossellini, enfraquecida no pós-68 (anos de chumbo em que optar pela contemplação em detrimento da enunciação podia soar regressivo, alienado, quiçá reacionário), mas recuperada nos anos $1980^{146}$.

Esses dois pólos - o de um cinema demasiadamente consciente de estar muito avançado na sua história e o de um outro que mal parece ter tomado conhecimento de que há uma história; ou ainda, o de um cinema sobre-enquadrado, sobre-dramatizado, sobre-excitado, sobre-saturado de citações e o de um outro que, inversamente, se apresenta como poesia bruta do presente assignificante - formaram as duas linhas de força determinantes nas décadas recentes, preparando o cenário no qual surgiram os filmes que analisaremos.

\section{Dispositivo, instalação, fluxo}

A mudança que se dá nesses últimos vinte ou trinta anos, desde o "momento maneirista", começa nos próprios materiais que se colocam à disposição dos cineastas: o que eles têm diante da câmera é o mundo ou apenas seus prolongamentos espectrais? O plano para esses cineastas é uma unidade de dramaturgia ou um exercício do olhar? O que está por trás desse plano é uma operação do pensamento ou um afeto momentâneo? Um conceito ou um sentimento? Ou os dois? Ou o intervalo entre os dois?

Esse conjunto de dúvidas se manifesta em alguns textos no começo dos anos $2000^{147}$, talvez como conseqüência lógica da passagem de um momento anterior (as décadas de 80 e 90), em que o cinema não oferecia mais a seu espectador a garantia de realidade mínima que havia sido sua marca durante muito tempo, mas ao contrário a "suspeita generalizada com o real”, para um novo momento em que esse estado de suspensão e dúvida se traduz num desejo renovado de "captar alguma coisa da preciosa 'ambigüidade' do real":

O que resta da "modernidade necessária", em todo um conjunto bem disparate de filmes que, de uns quinze anos para cá,

146 Cf. Aumont, O cinema e a encenação, pp. 112-114.

147 Ver, principalmente, "Plan contre flux" (Stéphane Bouquet, Cahiers du Cinéma n 566), "C'est quoi ce plan?" (Jean-Marc Lalanne, Cahiers du Cinéma $\mathrm{n}^{\circ}$ 569), “C'est quoi ce plan (la suite)?” (Olivier Joyard, Cahiers du Cinéma $\mathrm{n}^{\circ}$ 580). 
manifestam um vivo tropismo pelo acidente, a exploração da "assignificância do mundo", a improvisação ou sua aparência, o desfile mais ou menos ostensivo do autor-mestre, e sob diversas formas um certo respeito do real? O que resta disso em Gerry, onde um duplo personagem anônimo experimenta o mais fisicamente possível o perder-se no mundo (o labirinto sem muros)? Em Elefante, onde as causas são dadas mas como absolutamente opacas? Em Last Days, onde nada tem sentido? Em Mal dos Trópicos? Em Kaurismaki? Na obra, sintomática, e assim hipostasiada como o cúmulo do choque com o real, de Kiarostami? [...] Em 1990, um cinema moderno fundado sobre o respeito ao real não quer dizer a mesma coisa que em 1945 ou 1955. (AUMONT, 2007)

Respeitar a ambigüidade do real, explorar o acidental e o assignificante, não impor ao mundo um sentido mas aguardar que ele construa sua própria narratividade, seu próprio valor de ficção: estamos aqui no coração do que constitui, para Bazin, a essência do cinema, isto é, "a filmagem em continuidade, a desaparição da técnica, a epifania do real sensível, o bosque estremecido das pequenas diferenças que separam o 'cinema' das 'artes plásticas"'148.

Em todos os exemplos citados por Aumont, no entanto, o cultivo da opacidade do real vem incrementado pelo fato de que se trata de um real já fendido pelas dúvidas ontológicas que se acoplaram à imagem cinematográfica e metamorfosearam-na - por meio principalmente do digital, mas não só - justo ao ponto da fabricação de uma nova matéria plástica $^{149}$ que torna caduca a dicotomia baziniana entre crença na realidade e crença na imagem $^{150}$.

A imagem de cinema se vê "surpreendida mais que nunca em uma contradição entre a reivindicação do 'sonho' e o costume e a demanda de realismo. Porque assim como todos os rios conduzem ao mar, todas as perguntas sobre o cinema conduzem fatalmente à questão do realismo, donde encontramos de novo a questão do simulacro" (Michel Chion ${ }^{151}$ ). Um dos personagens principais do cinema recente é a imagem que ganha vida e se torna, ela mesma, objeto diegético - personagens-imagem, corpos-imagem. "O arquétipo, sob essas acumulações de imagem que ganham vida, é aquele do simulacro: o simulacro é a emanação de seu referente, incessantemente renovada e capaz de 'vir me procurar' para provocar minha

\footnotetext{
148 Pascal Bonitzer, "La pantalla del fantasma”, em BAECQUE, Antoine de (org.), Teoría y crítica del cine Avatares de uma cinefilia, Buenos Aires: Paidós, 2005, p. 71.

149 Algo de que Avatar (James Cameron, 2009), com sua técnica de "performance capture", representa o estágio mais avançado até aqui: corpo digital e corpo real se fundem em um só; o digital se acha integrado ao mundo foto-realista, ambos equalizados na mesma textura.

150 Ver André Bazin, “A evolução da linguagem cinematográfica”, em Qu'est-ce que le cinéma? - I: Ontologie et langage, Paris: Éditions du Cerf, 1958.

151 "Revolución suave... y duro estancamiento", em Teoría y crítica del cine-Avatares de uma cinefilia, p. 143.
} 
percepção"152. Para continuar propondo um mundo "ajustado a nossos desejos", o cinema deve saber mudar esses desejos, "por imposição da sociedade do simulacro que sucede à sociedade do espetáculo" (Aumont). A interposição das imagens/simulacros entre "o mundo" e eu (ou "os meus desejos") teria afastado para longe a evidência do mundo que, para Michel Mourlet, era a premissa fundamental do ideal da mise en scène. As últimas décadas, a tirar pelos diagnósticos de Chion e Aumont, teriam dado um novo contorno ao que Mourlet definiu como o triunfo inaugural do cinema, ou seja, a possessão imediata de um real pelo olhar impassível da câmera: o cinema não saberia mais se sua matéria é o mundo ou seu simulacro. Também não saberia mais ao certo qual o seu lugar na economia das imagens, o que repercutiria diretamente na reconfiguração desse "núcleo duro da linguagem cinematográfica que é o plano", cuja "dissolução" seria o traço mais explícito de uma nova disponibilidade do cinema a "regimes de imagens heterogêneos" 153 . Atravessado e inundado por imagens de todas as idades, texturas e naturezas, o cinema "imerge no grande banho indiferenciado do visual" 154 , numa espécie de "regime geral das imagens", e só com alguma dificuldade se pode tentar isolá-lo do manancial no qual ele se deixa "influenciar por seus vizinhos televisuais, vídeo-lúdicos ou artísticos" 155 . Não faltaram na última década "filmes de dispositivo semelhantes, por certos aspectos, a pequenas instalações":

Podemos facilmente imaginar Gerry, quiçá Last Days, no museu de arte moderna, sobre uma tela gigante numa área minúscula (como Passage de Bill Viola, 1987), ou sobre uma bateria de monitores colocados no chão ou pendurados a vinte metros de altura. (AUMONT, 2007)

No final dos anos noventa, pululam realizadores a que Stéphane Bouquet chama “cineastas-artistas que instalam seus dispositivos de percepção e suas apostas formais no centro dos filmes"156. David Lynch, David Cronenberg, Hou Hsiao-hsien, Tsai Ming-liang, Wong Kar-wai e Abel Ferrara são alguns dos “cineastas-artistas" mencionados por ele. As experimentações formais, para Bouquet, teriam saído da margem para ocupar o centro do cinema, ao menos do cinema que gera os debates estéticos mais intensos naquele momento:

E nesse caso o filme nos oferece tanto uma revelação do mundo como um intento de questionar o cinema em si mesmo,

\footnotetext{
152 Aumont, Moderne?, p. 110-111.

153 Frodon, "Une place pour les images", Cahiers du Cinéma, fevereiro de 2006.

154 E. Burdeau, "Résumé des épisodes précédents", Cahiers du Cinéma, fevereiro de 2006.

155 Olivier Joyard, "Contre la mort du cinéma", Cahiers du Cinéma n ${ }^{\circ}$ 574, dezembro de 2002.

156 S. Bouquet, "De manera que todo comunica", originalmente em Cahiers du Cinéma no 527 (setembro de 1998), republicado em espanhol em Teoría y crítica del cine-Avatares de uma cinefilia, pp. 160-169.
} 
impulsionando-o em seus cerceamentos, em seus limites, redefinindo sem cessar suas fronteiras, convertidas em porosas e instáveis, com o espetáculo ao vivo, a dança, o grafismo, a música, os ruídos, as imagens novas, as performances. (BOUQUET, 2005)

Simultaneamente à questão da "contaminação" do cinema com outras artes e outras formas de expressão e lazer (devemos ainda incluir na lista as ficções televisivas, os jogos eletrônicos etc), nesse texto escrito em 1998 Bouquet já coloca a outra grande questão que se deflagaria de vez no início dos anos 2000: novas aproximações de captura das coisas se fazem possíveis graças a uma "reciclagem massiva e generalizada do mundo como obra de arte potencial". Seguindo o exemplo dos artistas plásticos que trabalham com instalações, os "cineastas-artistas" cada vez mais iriam conceber seus filmes como "obras atmosféricas, ambientes sensoriais". O filme-instalação se assume como algo que não quer refletir nem decifrar o mundo captado pela câmera, mas tão-somente o isolar num espaço onde se possa experienciá-lo de maneira intensificada. Esses cineastas retomam, segundo Bouquet, uma proposta começada nas películas marginais de Andy Warhol e Marguerite Duras: a de fazer do filme "um entorno, um lugar, um espaço para habitar com todo seu corpo e um tempo para utilizar a seu gosto". Não há propriamente um filme para ver, mas um novo dispositivo de cinema que se deve habitar.

Nos dispositivos concebidos pelos "cineastas-artistas" contemporâneos, há um transbordamento do narrativo, uma vontade de algo que não seja só uma história (um sentido, uma emoção), mas que percuta no corpo, em "estados pouco evidentes do corpo e da consciência", submergindo o espectador num "banho de sensações novas". A "sutura" entre o narrador fílmico e o espectador já não depende mais da coerência do processo de narrativização. Outros circuitos de afinidade espectador-filme se estabelecem:

\begin{abstract}
A instalação provoca um deslocamento do corpo que não pertence à ordem do imaginário (como na ficção clássica), e sim a uma ordem mais sensorial, infra-intelectual. O que o cinema podia reter (e reteve) da instalação é, antes de tudo, a idéia da cenografia, isto é, a idéia de que o mundo não é uma paisagem real que é preciso captar, nem sequer um teatro (como o foi para certos autores antigos). $\mathrm{O}$ mundo cenográfico dos cineastas-artistas é um espaço museológico que há de se construir com os materiais que cada um escolhe. (BOUQUET, 2005)
\end{abstract}

Na primeira metade dos anos 2000, alguns filmes desdobrariam essa noção de cinemainstalação já anunciada e analisada por Bouquet alguns anos antes. Podemos utilizar dois exemplos posteriores ao texto para ilustrar e melhor entender como funcionam esses filmes 
que se assemelham a dispositivos de instalação: Blissfully Yours (2002), de Apichatpong Weerasethakul, e Last Days (2005), de Gus Van Sant.

Radical no aspecto "anti-narrativo", Blissfully Yours é uma soma de situações miraculosamente banais, que acompanhamos em sua duração quase completa, como se assistíssemos a uma lenta descamação da pele do real. A trama se reduz a quase nada: uma jovem moça forja um atestado médico para conseguir dispensa no trabalho e passar a tarde ao lado do namorado, um imigrante birmanês ilegal. Do tempo social do trabalho, tempo útil, passam a um tempo de lazer, tempo livre. Os créditos só aparecem com mais de quarenta minutos de filme, quando eles já estão a caminho da floresta onde farão piquenique. O filme começa de fato ali, na descoberta de uma outra experiência do espaço e do tempo. Uma amiga mais velha acompanha o casal em alguns momentos do filme, inclusive se encontrando com eles na floresta na parte final, mas as pontas de intriga que surgem dessa convivência são diluídas na temporalidade fugidia que se instala. Na sua última meia-hora, o tempo de fruição do filme praticamente bate com o tempo diegético: os personagens deitam à beira do rio para descansar; o som agradável da correnteza e das diversas formas de vida presentes na floresta ressalta a idéia de que aquilo tudo é um movimento de transformação incessante, e de que os próprios personagens, ao acordar, já não serão os mesmos. Os não-eventos que encerram o filme nos são entregues em sua duração bruta, mas é uma experiência leve, não é um tempo pesado. Em seu trabalho com a duração, Apichatpong está nos antípodas, por exemplo, de Andrei Tarkovski, e vale a pena se deter na comparação:

O tempo nos filmes de Tarkovski, ao contrário do que se pode pensar, não se dilata, pois é antes um enriquecimento da matéria por compressão: o tempo se acha adensado, massa compacta, sem esponjosidade e sem dispersão; ele é o somatório do que já passou, do que vai passar (talvez), mas nunca é o que está passando. A duração em Tarkovski não é uma potência aferida da passagem da natureza, mas uma sedimentação da matéria-tempo, uma erosão desse corpo robusto gerado por um acúmulo de depósitos de matéria semelhante à formação geológica avançada de um solo. Não é o tempo que deve ser encontrado na natureza, mas a natureza que deve ser encontrada no tempo. A erosão do tempo é sentida naqueles lentíssimos travellings que parecem se mover ao longo de uma atmosfera demasiado densa e espessa (afinal, ela nasce da condensação de toda a matéria do universo).

Em Blissfully Yours, vê-se o oposto: a duração não é uma "pressão do tempo" no interior de cada plano, mas antes uma depuração da natureza por ela mesma, que contém em sua matéria o tempo e flui tranqüila em sua passagem pelo homem. A superfície do tempo é límpida e lisa, e não suja e rugosa como em Tarkovski. O rio passa, as nuvens passam (há um 
inesquecível plano delas abrindo caminho para o sol), o dia se encaminha ao fim. O filme, no entanto, não dissimula sua "construção" por trás dessa duração frouxa e dessa falta de ações “interessantes"; percebemos a preexistência de um conceito. O trunfo de Apichatpong, então, consiste em preencher o dispositivo com uma presença do mundo em sua manifestação mais carnal, palpável, mais próxima de um contato físico com a natureza do que de uma superestrutura conceitual reguladora. "O filme-conceito se torna rapidamente filmedispositivo, que desaparece atrás do que ele mesmo produz. [...] De certa maneira, o espaçotempo que o filme instala engloba a sala de cinema ao passo que nega seu próprio meio narrativo" 157 . Ao drama e à ficção, Apichatpong antepõe a experiência de um espaço e a pregnância de uma duração.

O espectador de Blissfully Yours é convidado a um estado-limite da percepção, um alerta total da atenção visual e auditiva, com o detalhe de que a experiência não se nutre de nenhum desconforto intrínseco. O filme busca uma fruição leve e prazerosa, o que é surpreendente tendo em vista o estranhamento inicial que ele causa. Nos anos setenta, as propostas estéticas radicais que, apesar de sua não-convencionalidade, estavam voltadas para o cinema em seu formato convencional, como é o caso mal ou bem em Blissfully Yours (longa-metragem de exibição em salas), precisavam vir acompanhadas de toda uma pedagogia do olhar - pedagogia straubiana, pedagogia godardiana e por aí vai ${ }^{158}$. Os filmes de Apichatpong, entretanto, são relativamente "fáceis" de se ver e gostar. Ele reintegra no experimento o duplo prazer do espectador habitual do cinema: a participação afetiva e o prazer escópico (ir ao cinema para ver uns corpos inacessíveis apanhados em situações vivas e presentes).

Em Last Days, de Gus Van Sant, já não há propriamente um feelgood. A ambiência sensorial que o filme constrói é lúgubre, e não reconfortante como a floresta de Blissfully Yours. Last Days se inspira nos mistérios que rodeiam a morte do ídolo pop Kurt Cobain, mas tudo que sobrou para o filme foi a marcha zumbi de um morto-vivo, registrada em lentos e torporosos travellings em steadycam. Há também as cenas em que Van Sant filma esse murmúrio em forma de corpo desfalecendo no interior do plano fixo alongado, plano austero que, outrora ferramenta de concreção (cf. Straub/Huillet, Jean-Claude Biette, Manoel de Oliveira), aqui se torna forma de documentar a volatização de um corpo. O filme é um puro trajeto de virtualização, confluindo para aquela cena final em que o espírito de Blake-Cobain sobe degraus imaginários até sair de quadro (cena irmã gêmea do espírito que sai de uma vaca

\footnotetext{
157 Ver Erwan Higuinen, "Beauté béate”, em Cahiers du Cinéma, outubro de 2002.

158 Cf. Serge Daney, A rampa.
} 
em Mal dos Trópicos [2004], de Apichatpong). Decantação de um duplo virtual que subsiste ao corpo, a imagem de Blake se despe da matéria, do peso - resultado natural de um filme em si mesmo impalpável, fantasmático.

Em Elefante (2003), o que tornava o massacre promovido por dois adolescentes numa típica high school norte-americana um evento tão mais estranho do que já seria normalmente - e aumentava seu suspense - era a beleza inevitável daquele balé de corpos que o precedia (os adolescentes, em sua maioria bonitos, deslizavam languidamente pelos corredores da escola sem saber que destino os aguardava). Em Last Days, Van Sant já não oferece a mesma volúpia nem o mesmo suspense. O que fazer com um conjunto de acontecimentos nebulosos e deslocamentos sem sentido? Essa é a questão que se coloca à montagem e esta se esforça em não responder diretamente, construindo o espaço por meio de raccords enigmáticos verdadeiras desarticulações de um labirinto espaço-temporal. Estamos imantados menos ao ponto de vista de um personagem ou à intensidade emocional de um drama do que às operações de um dispositivo.

Um dos procedimentos principais do cinema de dispositivo, voltando ao texto de Bouquet, seria o isolamento: "a câmera cria um espaço deslocalizado, uma zona intermediária", provoca um "efeito de clausura sensorial", "porquanto a menor abertura pode despertar a consciência e impedir o efeito de translação do espectador".

o objetivo dos cineastas-artistas é antes produzir um mundo a partir de um Princípio primeiro, claramente enunciado, do que observar o mundo real, sob o risco de organizá-lo ao redor de um ponto de vista (posição clássica do cinema de autor). [...] O mundo real, a partir do momento em que contém a promessa da heterogeneidade, da alteridade, do acaso, só pode ser vivido como ameaça. (BOUQUET, 2005)

Nesse universo fechado, o estatuto do fora-de-campo se torna problemático: para que ele não quebre a clausura do universo fílmico, é preciso anulá-lo, ou melhor, integrá-lo de uma maneira ou de outra ao campo:

a oposição entre campo e fora-de-campo é abolida em função de uma oposição de fluxo (as imagens)/punção (os planos). Desaparece, no fundo, o olhar organizador do mundo (o conceito estético de campo remete evidentemente à delimitação de um mundo, o do autor) em proveito de uma concepção do artista como quem faz circular as imagens. (BOUQUET, 2005)

No final da década de 1990, portanto, o cinema estaria se dividindo entre uma estética 
pautada na planificação (logo na montagem) e uma estética de circulação e fluxo, livre escoamento de imagens sem fora-de-campo, sem relações concretas de alteridade e heterogeneidade.

Quatro anos depois, Bouquet desenvolverá melhor essa oposição entre plano e fluxo, inserindo a discussão numa reflexão sobre a história das formas artísticas que alude à pintura do século XVII, quando artistas e teóricos rivalizavam acerca da primazia do desenho ou da cor. O texto ${ }^{159}$ cita a revolta de Poussin contra Caravaggio, que o primeiro acusava de "destruir a pintura" por renunciar às "belas idéias", ao desenho, para aderir aos charmes sedutores da $\operatorname{cor}^{160}$. Para os defensores do desenho, era preciso rechaçar o caráter físico da cor, e preferir a nitidez do contorno ao "traço", porque este não define a construção formal das figuras, mas antes sua própria indefinibilidade, sua imensidão, sua inabalável imanência. Desenhar, portanto, não era copiar o real, mas pôr em obra um saber, uma lógica, uma ordem do mundo. Porque definia os objetos perfazendo os seus contornos, o desenho era percebido como um incomparável instrumento de conhecimento, um meio de definição das coisas e conseqüentemente uma materialização da idéia.

Jacqueline Lichtenstein esclarece melhor as bases históricas do debate, que surge na Itália já durante o Renascimento:

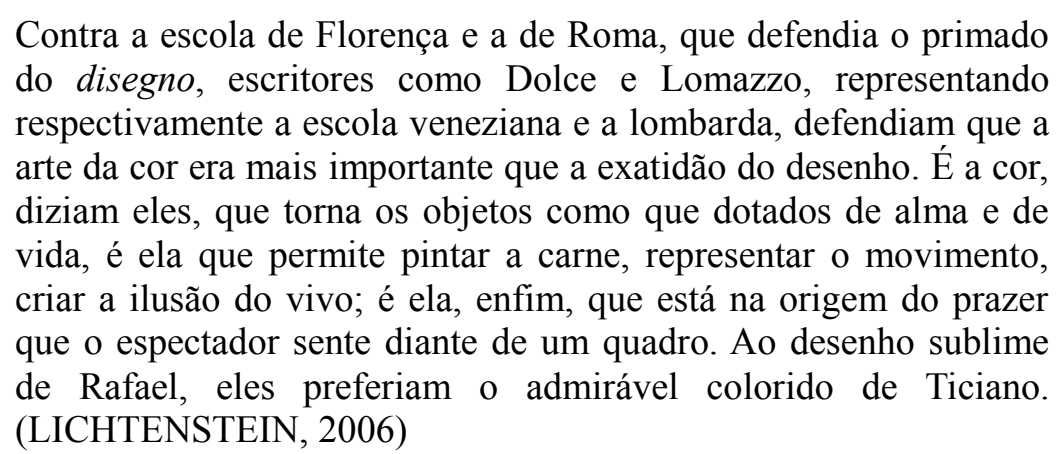

Ao invés de mergulhar no lado analítico e racional do pensamento, portanto, a cor ocupa o lado da consistência das coisas, da sensação, da confusão das formas, da profusão do real. Mas os teóricos defensores da arte do desenho, a exemplo de Vasari, insistirão na necessidade de definir a pintura por uma parte que procede essencialmente do intelecto:

Aristóteles já o sugeria na Poética: ao contrário da cor, cuja beleza resulta de um impacto simplesmente material, da simples habilidade manual, e até do acaso, como o comprova a história tantas vezes

159 "Plan contre flux", em Cahiers du Cinéma n ${ }^{\circ} 566$.

${ }^{160}$ No debate estético desenho-cor, como veremos a seguir, o opositor de Poussin freqüentemente citado é Rubens, e não Caravaggio. 
citada de Protógenes, o desenho remete sempre à ordem de um projeto; pressupõe uma antecipação do espírito que concebe abstratamente e representa mentalmente a forma que quer realizar, o objetivo que busca atingir. $O$ desenho não é matéria, nem corpo, nem acidente, escreve Zuccaro na Idea del pittore, e sim forma, concepção, idéia, regra e finalidade - em suma, uma atividade superior do intelecto. [...] Embora reconhecendo a importância da cor, a maior parte dos teóricos continuará a privilegiar o desenho, que exige do artista e do espectador um ato de abstração em relação ao pathos do sensível e um ato reflexivo para compreender a engenhosidade da invenção.(LICHTENSTEIN, 2006)

Na França no século XVII, o debate se agudiza. Adaptando as idéias difundidas na Itália renascentista, os franceses, adeptos dos dualismos severos e das doutrinas baseadas em regras restritas, "transformaram o que era uma divergência entre pontos de vista contrários, mas não contraditórios, num antagonismo violento em que se chocam posições consideradas incompatíveis". “Opõem-se os 'poussinistas', defensores do desenho, aos 'rubenistas', partidários da cor"161. A concepção de pintura defendida pelos poussinistas foi legitimada na Academia Real de Pintura e Escultura, que se incumbia de uma tripla função: pedagógica, teórica e política. Três objetivos que pressupõem uma definição da pintura baseada na excelência do desenho, única parte da pintura passível de um aprendizado escolar, já que, contrariamente à arte da cor, que escapa a qualquer regulamentação, sua prática obedece a regras. Se a cor parece escapar aos preceitos de uma ciência reflexiva, o desenho, por sua vez, pode ser descrito em termos de harmonia, imitação e invenção, prestando-se, portanto, a uma doutrina oficial. "Origem da criação pictórica e meio de expressão das figuras, o desenho possibilita a formação de um conceito baseado em critérios comuns" ${ }^{\text {"162 }}$. É também o primado do desenho o que melhor permite "narrar com um pincel", construir relatos históricos sem ambigüidade, favorecendo a difusão dos preceitos políticos da monarquia absoluta.

A estética colorista dará o troco a partir de um caminho aberto por Roger de Piles no período (1668-1699) em que ocupa o cargo de conselheiro na Academia. Seu elogio da “maquiagem” em Rubens é “a pedra angular de uma argumentação que desemboca simultaneamente numa nova teoria da pintura, definida em termos de autonomia e de especifidade, e numa estética original do prazer e da sedução"163. O colorido é então valorizado como traço distintivo da pintura e fonte do prazer específico que o espectador desfruta diante do quadro. "É o desenho que dá forma aos seres; é a cor que lhes dá vida", diz Diderot. Evidencia-se uma tendência a apagar os limites tradicionais entre a forma, o

161 Lichtenstein, A pintura - Vol. 9: O desenho e a cor, p. 13.

162 Ibidem, p. 14.

163 Ibidem, p. 16. 
modelado e o contorno, e de superar o conflito entre o desenho e a cor. Nos séculos XIX e $\mathrm{XX}$, do Impressionismo ao Expressionismo abstrato, passando por Van Gogh e Cézanne, a idéia de que a forma deve nascer da própria cor fornecerá ao debate estético um vasto campo.

$\mathrm{Na}$ dicotomia de Stéphane Bouquet, o primado do desenho teria seu paralelo cinematográfico na estética do plano. Já à arte da cor corresponderia a estética do fluxo.

A estética do plano pressupõe a possibilidade de uma ordem transcendente dar forma ao real, o que implica uma construção tijolo a tijolo, uma fluência dramática e discursiva obtida pela junção de unidades significantes (planos que se somam em cenas que se somam em seqüências e assim por diante). Um cinema que reside nos poderes organizadores da abstração racional, e que tem seu passado ligado a Hitchcock, Lang e outros cineastas da manipulação de uma diegese, da construção de mundos regidos por uma lei de organização mental. A mise en scène, na estética do plano (ele cita François Ozon como exemplo), consiste em organizar o inorganizado, estruturar o que por natureza é inestruturado, para ao fim construir um sentido ou uma emoção.

Os cineastas do fluxo (Hou Hsiao-hsien, Claire Denis, Wong Kar-wai, Gus Van Sant, Tsui Hark ${ }^{164}$ ), diferentemente, não captam ou recriam o mundo segundo articulações do pensamento que se fariam legíveis nos filmes. Eles realizam um cinema de imagens que valem mais por suas modulações do que por seus significados. A tarefa do cineasta do fluxo consistiria não em organizar uma forma discursiva, mas em "intensificar zonas do real", resguardar do mundo um estatuto aleatório, indeciso, movente. A câmera se dedicaria, sobretudo, a atualizar certas potências: "diferente de poder; o poder é extensivo e mensurável, construído e controlado, como um efeito (retórico); a potência é intensiva, incomensurável e indomável, como um afeto (psíquico)" (Philippe Dubois). O cinema de fluxo se constrói na mistura, na indistinção, em último grau na insignificância mesma das coisas.

No texto em que retorna à questão do fluxo, Stéphane Bouquet afirma: "O Ser não é mais idêntico a si mesmo, mas flutuação generalizada" 165 . Isso lhe parece ser a pedra filosofal desse cinema. Na sua principal ressalva à estética de fluxo, Bouquet aponta nela uma "dupla tendência regressiva", retomando um argumento que já utilizava no texto sobre os "cineastasartistas" no final dos anos 1990, que é aquela constatação de que eles fazem um cinema alheio à alteridade e ao conflito:

De uma parte, o fluxo é um pregueamento do cineasta sobre o

\footnotetext{
164 Podemos incluir também Apichatpong Weerasethakul, Naomi Kawase, Lucrecia Martel e Philippe Grandrieux.

165 “Des films et des gestes", in Cahiers du Cinéma n n 578, abril/2003.
} 
coração de seu desejo fora do temível real que é forçosamente ruptura. Não é garantido desse ponto de vista que Tsui Hark ou Hou Hsiao-hsien, Wong Kar-wai, Claire Denis sejam cineastas menos reacionários que Sokourov, ou seja, menos assombrados pela reconstituição de um paraíso perdido ou mesmo jamais possuído; de outra parte, o fluxo não oferece nenhuma possibilidade ao Outro de se manter na borda do filme, ou ao lado. É um mundo sem diferença, sem alteridade. É preciso mergulhar no movimento comum, ceder o pensamento pela sensação. (BOUQUET, 2003)

No fundo, o que Bouquet está designando como uma tendência regressiva pode representar tão-somente o desrecalcamento de uma pulsão conservadora que corre subterraneamente sob a malha de toda a história do cinema: o instinto de recuperar uma "sensorialidade primeira", uma carne merleau-pontiana do visível, cuja captura implica um trabalho menos de dramaturgia que de "intensificação" de nossa sensibilidade aos fenômenos. Se o cinema de fato estava encerrando um ciclo nas décadas de 80 e 90, tanto por forças internas como externas, então o passo natural a seguir seria mesmo um retorno ao estado de repouso que Freud descreve como o objetivo de toda vida: a regressão e o restabelecimento de um estado anterior. Os estetas do fluxo, assim, estariam se reaproximando de um sentimento oceânico que os estágios avançados da cultura e da civilização costumam relegar ao subsolo.

Não podemos deixar de observar que o arcabouço conceitual desse cinema de fluxo que se mostra tão "em fase" com o mundo atual comporta, em sua novidade ou atualidade mesma, um destronamento do pensamento dialético e do drama psicológico em favor de uma forte presença da fenomenologia - em sua versão mais "sensualista" - e das posturas contemplativas que o marxismo interditava ("Por que os cineastas marxistas, uma vez que a filosofia marxista abandonou a contemplação, deveriam seguir contemplando e dando a contemplar o mundo em luta?" $\left.{ }^{166}\right)$. A essa mudança de paradigma corresponde uma predominância do modelo artístico do sismógrafo sensível às variações do presente, mas afásico, incapaz de enunciar sua estrutura. Uma arte pautada pela busca de "uma forma de não intervenção no mundo", "uma apresentação pura desligada de toda organização significante" (Bouquet). No lugar do conflito como premissa para a progressão narrativa, instala-se um "fluxo esticado" de imagens, um cinema en apesanteur, que pode se livrar ao estágio mais relaxado do "prazer auto-erótico do olho enlaçando uma realidade evanescente" (Pascal Bonitzer). No lugar da densidade psicológica, enxertam-se blocos de afetos, fragmentos de vida sem significados fechados, uma primazia do sensorial e do corpóreo em detrimento da

$\overline{166}$ Bonitzer, "La pantalla del fantasma”, em Teoría y crítica del cine, p. 72. 
psicologia e do discurso. Filmes sem clímax, sem oscilação dramática, marcando uma certa indiferença do tempo à passagem dos fatos. Mais importante que o encadeamento das ações é a invenção de uma "nova rítmica do olhar", é criar a sensação mais que o sentido. O drama ora fica encoberto, ora é mantido à distância, ao menos o drama no sentido forte, ou seja, da confrontação dramática, do heroísmo, da tragédia, da violência glorificada, da construção de um mundo sustentado por alguma gravidade, alguma ênfase. Há uma propensão ao arejamento estético, quiçá ao insólito, à ausência de peso, antítese radical do classicismo, já que no cinema clássico, ou derivado do clássico, o cineasta trabalha sob o (ou através do) olhar de algo maior que o homem: a Lei, o Tempo, a Arte, o Destino, Deus (o que faz de Clint Eastwood um "clássico", nesse sentido, é menos a decupagem do que a existência de forças que pesam sobre os personagens).

Foram muitos os filmes que, na década que agora se encerra, apresentaram as características acima descritas. Fiquemos em dois exemplos que, por ora, nos permitirão compreender melhor tais características e nos darão referenciais importantes para a pergunta que faremos em seguida.

O primeiro é A Mulher Sem Cabeça (2008), de Lucrecia Martel, cuja protagonista é uma mulher de meia-idade, Verónica, que parece em estado de catatonia. Tudo começa quando ela atropela um ser vivo (um dos meninos que aparecem na cena de abertura? ou o cachorro que está com eles? ou algum outro que sequer vimos antes?), mas não presta socorro e segue em frente. A cena do atropelamento é paradigmática: um plano-seqüência filmado de dentro do carro, focado no rosto de Verónica; há um solavanco, ela pára o carro, mas não sabemos ainda o que aconteceu, a câmera permanece nela, o fora-de-campo se infla na nossa imaginação à medida que nos é adiado o acesso a ele. Depois que Verónica recoloca o carro em movimento, corta para um plano em que vemos, pelo vidro traseiro, bem ao longe e se distanciando cada vez mais, um corpo estendido na estrada de terra. Os dias que se seguem ao incidente são filmados igualmente do ponto de vista dessa clausura empirística que pautou a cena do atropelamento. A câmera se cola em Verónica e uma profusão sensorial nos impede de concatenar os fatos; estamos mergulhados num cotidiano atormentado pela culpa, pela dúvida, pela indefinibilidade.

O que quer que tenha cruzado o caminho de Verónica, sua presença-ausência agora assombra todos os enquadramentos do filme. O drama se internaliza e se virtualiza, desaparece por trás da banalidade cotidiana, dissimula-se no fundo quase sempre desfocado das imagens, evanescendo a presença do mundo ao redor da personagem principal. Os estímulos aferentes do mundo objetivo e da percepção sensível são desproporcionais a seus 
efeitos na consciência, e esta já não serve de testemunho fiel das relações entre o ego e o mundo exterior. O olhar seleciona patologicamente as partes do real que lhe interessam e afetam. A alteridade se torna uma memória distorcida do fora-de-campo. A ficção, ou o que sobra dela, consiste na errância de uma mulher desconectada de um arrière-monde tornado mais e mais abstrato. A narrativa é pura passagem, passagem que não progride, não vai de $\mathrm{A}$ a B, mas de A a A', A" e assim por diante - sutis variações em torno de um mesmo estado afetivo instaurado desde o início. No lugar da ação, a afecção. O filme se constrói à semelhança do comportamento de Verónica na cena do atropelamento: dilatando o intervalo entre ação e reação (a atuação da atriz principal, María Onetto, rosto transformado em placa reflexiva imóvel, parte de um limitado repertório de nuances de expressão). É a imagemafecção - tal como Deleuze a definiu em Imagem-Movimento - quase que didaticamente exposta: a imagem que absorve uma ação exterior e reage interiormente.

O outro exemplo é Café Lumière (2003), de Hou Hsiao-hasien, que, como de costume em seus últimos filmes, combina a experiência bruta da duração, da matéria-luz e do movimento a um conteúdo dramático sutil, singelo, quase imperceptível. Ele integra o fluxo contínuo e inextricável do cotidiano a uma composição cênica concentrada nos detalhes. $\mathrm{O}$ drama se constrói quase que na sua ausência mesma, diluído na correnteza de situações prosaicas que a narrativa propõe.

O filme acompanha os pequenos atos de Yoko (Yo Hitoto), jovem moça que está grávida de três meses mas não tem intenções de reencontrar o pai do bebê. A gravidez fica, na verdade, como pano de fundo dramático, um enredo em latência, ou em gestação. O que vemos são andanças de Yoko por uma Tóquio sempre povoada, seus trajetos de um trem para outro, suas visitas e encontros com o amigo Hajime (Tadanobu Asano), rapaz que tem por hobby gravar os sons das diversas estações de trem por onde passa. A atitude de Hajime nas estações de trem, com seu gravador ligado e o microfone aberto a todo e qualquer som que o mundo tem a oferecer, é análoga à atitude do próprio Hou, que liga a câmera e aguarda pacientemente pelos brotamentos do cotidiano, confiante de que seu cinema nasce de um pacto com a efemeridade dos instantes e com a contemplação parcimoniosa do mundo.

Os dez planos que compõem a seqüência final de Café Lumière são bastante ilustrativos quanto ao estilo de Hou e sua postura diante da dinâmica de uma grande cidade:

1) Yoko vem andando por uma calçada, enquadrada de longe pela câmera, que vai fazendo uma lenta panorâmica à direita para acompanhar a personagem. Placas de trânsito, transeuntes e carros que passam na rua se interpõem entre a personagem e a 
câmera.

2) Yoko parada numa pequena plataforma de trem, em plano médio. O trem chega do fora-de-campo, pela direita, e Yoko e outras pessoas a ele se dirigem. A câmera faz um breve reenquadramento, enquanto as pessoas terminam de entrar, o trem fecha as portas e parte.

3) Yoko dentro do trem, de pé, junto à janela.

4) Plano geral de uma estação. O trem se aproxima chegando do fundo. Uma panorâmica à direita acompanha o trem quando este passa pela câmera e pára mais à frente. Yoko e outras pessoas saem do trem.

5) Yoko viaja sentada dentro de mais um trem, rodeada de outros passageiros. Ela pega no sono.

6) Hajime entra no trem. Ele possui um microfone, com o qual grava sons da estação. Hajime fica parado perto da porta, até que percebe a presença de Yoko. Ele se aproxima dela, a câmera faz um tilt que a mostra dormindo e depois retorna ao rosto de Hajime, que sorri ternamente.

7) Yoko acorda aos poucos e percebe Hajime à sua frente. Ela sorri.

8) Plano geral de uma estação de trem maior que a anterior. $O$ trem chega do fora-decampo, pela direita. Hajime e Yoko saem pela porta que se abre próximo à câmera e ficam por ali, apanhados em plano médio geral. Várias outras pessoas saem do trem e transitam pela plataforma. Yoko fica bem à esquerda do plano, saindo de quadro. Hajime aponta o microfone ao seu redor. A câmera faz um leve reenquadramento, traz Yoko de volta ao plano. Ela anda até um ponto mais ao fundo, Hajime continua parado à beira da plataforma, gravando os sons da estação. $\mathrm{O}$ trem vai saindo. Os personagens continuam lá; ele gravando sons, atento, ela andando para a esquerda, saindo de quadro novamente.

9) A câmera agora está do outro lado da plataforma, e um trem passa bem à sua frente. Vemos Hajime e Yoko refratados pela imagem riscada do trem que passa.

10) Tomada geral feita do alto de um ponto estratégico da cidade, apanhando três linhas de trem ao mesmo tempo. Em cada linha, vemos um trem indo em alguma direção. Passam cinco trens ao longo do plano, somando quatro trajetórias distintas (duas na horizontal e duas na vertical). No centro da imagem, há ainda um rio cujas águas somam mais uma trajetória, fluindo de cima para baixo do plano, calmamente. É essa trajetória, ou essa correnteza, que a câmera vai acompanhar, com um delicado tilt, antes do fade-out que encerra o filme. 
Estamos aqui no extremo oposto em relação às sinfonias urbanas do final dos anos 1920 (Berlim: Sinfonia de uma Cidade [1927], de Walter Ruttmann, seria o exemplo mais óbvio). O cinema de Hou não está a serviço de utopias sociais ou odes ao progresso. Não há finalidade mecânica nos movimentos, a jornada de trabalho não está lá como medida do tempo e da velocidade, não há horizonte de triunfo da metrópole ou de epopéia urbana grandiosa. A Tóquio de Café Lumière é um lugar de trajetórias entrecruzadas, um espaço de circulação, de um ir-e-vir tranqüilo, sem orquestração coletiva (estaríamos mais no terreno da música minimalista). Hou filma "a vida como fato enérgico" (Burdeau), um simples estar-nomundo transformado em matéria dramática. Pouco a pouco percebemos que o cotidiano indolente de Café Lumière transborda de afetos. Entre Yoko e Hajime, ou entre Yoko e seu pai, há toda uma rede muda de afetividade.

O princípio de composição é o da transitoriedade: os enquadramentos nos são apresentados como algo provisório, nunca fixado nas suas bordas, e sim sujeito a reconfigurações por movimento de câmera ou entrada/saída de atores. Na seqüência final aqui descrita, nota-se a profusão de elementos que atravessam o plano (pessoas que passam de um lado para outro, carros, movimentos), assim como a recorrência de reenquadramentos e refocalizações, às vezes até perdendo de vista os personagens. O enquadramento é um ponto de vista possível e transitório, e não o ponto de vista privilegiado a partir do qual se poderia delimitar a cena. O cinema é dramatizado em termos do próprio limite do visual, da externalidade necessária e estrutural da câmera, da sua incompletude. É importante notar que o plano se assume como percepção redutora somente para se abrir ao mundo, cada enquadramento trazendo a informação de que há muito mais coisas na realidade que o transborda do que nas suas delimitações precárias. Hou retorna em grande parte à atitude dos pioneiros do cinema (e de fato este filme assume já no título uma homenagem a Lumière), isto é, à necessidade de captar o movimento do mundo, um mundo ao qual ele, Hou, pertence, está imerso, não o podendo representar senão de um ponto de vista e um instante infinitamente passageiros.

Ao retomar o cinema do ponto em que Lumière o havia deixado, Hou Hsiao-hsien parece reaproximar-se dos primeiros "paradigmas" que André Gaudreault ${ }^{167}$ identifica na cinematografia dos primórdios: "captação/restituição" do real que supõe um limiar mínimo de intervenção por parte do filmador e que é "refratário a toda manipulação" ("não se trata então, para ele, senão de garantir a captação optimal do evento profílmico"); “mostração" de vistas

${ }_{167}$ Cf. Cinéma et attraction, Paris: CNRS Éditions, 2008. 
prises sur le vif, com manutenção da integridade temporal absoluta do evento filmado; aglomeração ou acumulação de registros sem tessitura de ligações mais próximas entre os fragmentos, sem concatenação de planos, sem raccord (a comunicação entre os planos só se daria de forma mais seqüencial e íntima a partir do paradigma da "narração"). A mise en scène se "limita" novamente à escolha de um ângulo, de um ponto de vista mediante o qual o simples registro de uma realidade, de uma certa maneira de ser no mundo, se tornará uma arte, uma arte pautada na manifestação exterior e na presença imediata dos eventos. Talvez a verdadeira modernidade de Hou Hsiao-hsien esteja aí, em sua capacidade de recuperar esse impulso original, essa espécie de "narratividade nativa" que deriva intrinsecamente de uma propriedade da máquina-cinema. "Quando se leva uma coisa tão longe quanto ela pode ir, muitas vezes se volta ao ponto de partida" (Clement Greenberg).

\section{"Será o fim da mise en scène?"}

Por tudo que vimos até aqui, uma parcela importante do cinema contemporâneo parece ter ocupado um ponto cego em relação à definição clássica de mise en scène que estudamos na parte I deste trabalho. Tal constatação já é esboçada por Jean-Marc Lalanne quando ele retoma o conceito de estética de fluxo cunhado por Stéphane Bouquet:

\footnotetext{
Um fluxo esticado, contínuo, um escorrer de imagens no qual se abismam todos os instrumentos clássicos mantidos pela própria definição da mise en scène: o quadro como composição pictural, o raccord como agente de significação, a montagem como sistema retórico, a elipse como condição da narrativa. [...] A montagem é reduzida a um trabalho mínimo: trata-se simplesmente de juntar, como vagões, imponentes planos-seqüência, verdadeiros blocos de granito indivisíveis. (LALANNE, 2002)
}

O plano, desse modo, não é mais "a parte de um todo", ou "a menor unidade de significação no cinema", mas antes um recorte "aleatório" do fluxo irrefreável das aparências que constituem o real (ou sua ilusão). Nem a montagem é mais capaz de salvar esse plano do caos perceptivo e conferir-lhe algum sentido, alguma margem de observação e compreensão; a montagem apenas corrobora a desordem empírica dos acontecimentos.

A mise en scène se acha rarefeita enquanto "gestão de cenas", pelo fato (anterior) de que, no lugar onde costumeiramente se viam cenas bem demarcadas, com contornos exatos, agora se apresentam eventos de bordas esfarrapadas, eventos de contornos fluidos, 
imprecisos.

Em seu livro $O$ cinema e a encenação, Jacques Aumont vai mais longe e se pergunta: “Será o fim da mise en scène?". Embora relativize a situação, verificando a permanência de filmes que ainda praticam uma arte do plano e da decupagem no sentido clássico, ele afirma que “a mise en scène não reina mais nos filmes como reinava em 1919, em 1939, em 1959”. Pegando O Intruso (2004) de Claire Denis como exemplo paradigmático, ele observa a recorrência de filmes contemporâneos que se constroem na lógica da sensação (e não da encenação) e levam ao limite "a autonomia e a liberdade do ponto de vista da câmera", destacando também o caráter selvagem das elipses e da narrativa como um todo:

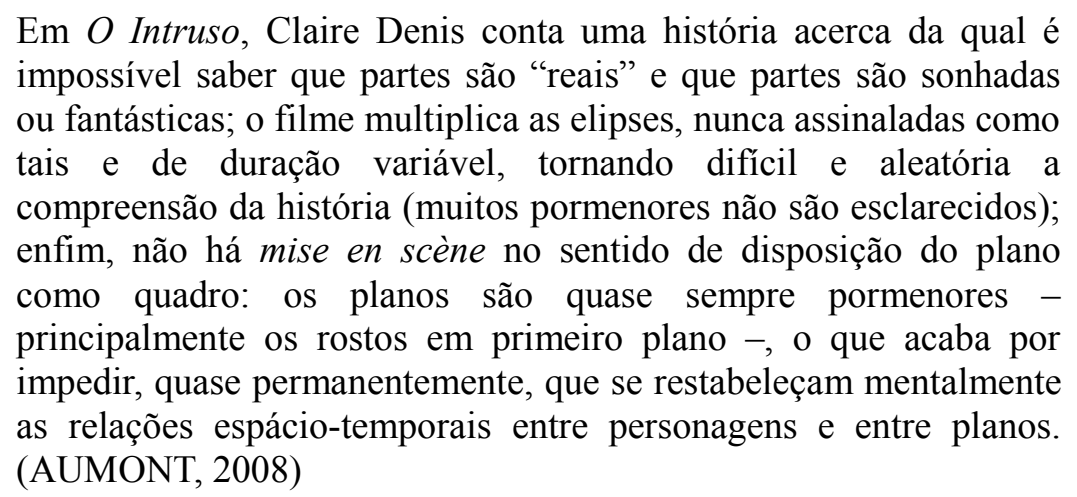

Assim como ocorre em O Intruso, a mise en scène em Café Lumière (Hou), A Mulher Sem Cabeça (Martel), Last Days (Van Sant) e Blissfully Yours (Apichatpong) se fragmenta, ou se liqüefaz. O drama se pormenoriza, a moldura do plano se torna arbitrária ou incerta, somem as marcas teatrais do espaço. O primordial do filme passa a ser a intensidade particular de cada registro - intensidade como o não-construído, o não-instituído, o que precede as capacidades organizadoras e articuladoras do pensamento.

Num texto escrito após o Festival de Cannes de 2005, Stéphane Delorme afirma que, acometidos por um "defeito de articulação", Three Times (Hou Hsiao-hsien) e Last Days caminham para o lirismo integral, a pura ambiência, o mood, ressaltando que em Elefante e Mal dos Trópicos, e sobretudo em Dez (Kiarostami, 2002), uma dialética ainda subsistia entre a narrativa e o lirismo, entre o antes e o depois, entre a realidade e seu pesadelo/sonho, entre o "eu" e o "você". Mesmo Gerry, a despeito do laconismo de seus personagens e da sua narrativa errante, associava "o estado de suspensão ao suspense da aventura, o impasse ao espírito de viagem, a solidão à companhia". Three Times e Last Days, todavia, parecem se furtar completamente ao conflito e à articulação: o filme se descola da narrativa e da palavra e se torna um exercício contemplativo disposto em blocos-seqüência de mutismo patente, em 
vez de um pensamento em ação e exposição ${ }^{168}$.

Estariam Hou Hsiao-hsien e Gus Van Sant, assim como Claire Denis, Apichatpong Weerasethakul, Naomi Kawase, Philippe Grandrieux e Lucrecia Martel, trocando o domínio da articulação por uma espécie de infra-linguagem? Estariam abandonando o terreno da mise en scène e da montagem para reapresentar o cinema como "a constituição de um espaçotempo primordial" (Jacques Rancière)? Haverá mise en scène fora de toda articulação e de toda significação? Arrancada dos moldes pictóricos, destituída de sua herança teatral, a cena se torna o quê? Pode existir mise en scène sem cena?

Nos textos que abordamos na parte I, e no cinema dos autores que eles propunham teorizar (Hawks, Rossellini, Lang, Fuller, Losey, Walsh, Preminger, Mizoguchi, entre outros), o elemento fundador da mise en scène era um olhar diante do mundo, como Michel Mourlet tanto enfatizou. Acesso ao sublime ou à abjeção, expressão de um acordo ou de um conflito entre um corpo e o mundo do qual ele é o veículo de conhecimento, o fato é que a mise en scène era a emanação de um ponto de vista situado frente ao mundo (ou contra o mundo, se preciso fosse).

O que vemos em toda essa parcela do cinema contemporâneo que estamos agora a analisar, diferentemente, é uma estética derivada de um olhar não mais diante do mundo, seja para buscar nele um acordo ou uma dissonância, e sim imerso no mundo, ou num "intermundo", como Delorme propõe no último texto de um dossiê dos Cahiers du Cinéma que, em fevereiro de 2006, busca sistematizar sob a rubrica um tanto vaga de "cinema sutil" as transformações que ocorreram nas últimas duas décadas. Delorme afirma que o processo de "sutilização" que leva o cinema a um "estado imperceptível" se pauta pela recorrência de personagens que, submetidos às "leis da afecção", perdem-se entre duas hipóteses, dois mundos, ocupando o intervalo entre eles, ou melhor, flutuando em uma espécie de "intermundo". "Ao redor deles, o escoamento de imagens entre ficção e documentário, entre miniatura e gigantismo, maquete e monumento [...] Se o sutil é um inter-mundo que se nutre de paradoxos, o afeto reintegra nele feridas cortantes: antes/depois, dentro/fora, essencial/acidental" ${ }^{\prime 69}$. Um cinema que faz o espectador imergir nas imagens: o olhar, antes em atitude de afrontamento, agora está envelopado, numa situação em que lhe é impossível apreender o contorno da experiência contida no filme. Temos acesso à intensidade da experiência, mas não a seu significado. Assim como os personagens, somos ultrapassados pelos eventos; o olhar é carregado por um manancial e se perde dentro dele. O espectador não

168 Delorme, "Un défaut d'articulation", Cahiers du Cinéma n ${ }^{\circ}$ 602, junho de 2005.

169 Delorme, “Les lois de l'affection”, Cahiers du Cinéma, fevereiro de 2006, p. 78. 
precisa ir contra ou a favor do que vê. Basta-lhe habitar um espaço criado para a convivência entre corpos e imagens.

"É preciso uma distância", dizia Alexandre Astruc ao tentar definir o que é a mise en scène: "o autor dobra os elementos do universo que mostra não à sua visão própria, mas a uma certa necessidade de criar um recuo em relação a eles: sabedoria ou vontade de sabedoria" 170 .

Os cineastas contemporâneos aqui enfocados aboliriam justamente o "recuo" e a "vontade de sabedoria", em prol de uma imersão no caos sensível ou de uma contemplação não-significante.

A mise en scène que estaria chegando ao "fim", portanto, é aquela que era reconhecida como a organização e a disposição de um mundo para o espectador, como a mise en place dos atores num cenário e seus deslocamentos no interior de um quadro (Mourlet), como o resultado de uma "operação intelectual que pôs em obra uma emoção de partida e uma idéia geral" (Fereydon Hoveyda), como a força do acaso e da dimensão documental do cinema unida à vontade de ordenação e de harmonia (Rohmer), como o enfrentamento e a expressão de um conflito entre "o ponto de vista de um homem, o autor, mal necessário", e o mundo que ele filma (Rivette), como a absorção da ação no cenário e da significação na forma (Lourcelles), como a captura do real sensível aliada a uma dramaturgia cênica.

Quando, diante dos filmes de Claire Denis, Hou Hsiao-hsien e cia, interrogamos onde está a mise en scène, automaticamente interrogamos também onde está a cena, onde está a forma, onde está a articulação das pequenas unidades - o quadro, o plano - ao todo narrativo, qual o papel do ponto de vista, qual o papel do ator, em que consiste (ou inexiste) a dramatização... O que faremos agora é justamente percorrer um por um esses pontos, além de alguns outros que surgirão.

$\overline{170}$ Astruc, “Qu'est-ce que la mise en scène?”, Cahiers du Cinéma nº 100, outubro de 1959. 


\section{A matéria}

Em suas Cartas sobre a Educação Estética da Humanidade, Schiller fala de dois impulsos que sempre estão em ação no ser humano: o "impulso-matéria" [Stofftrieb] e o “impulso-forma" [Formtrieb $]^{171}$. O impulso-matéria, ou "impulso sensível”, diz respeito à existência física do homem submetido às limitações do tempo, existência que se manifesta através das sensações, cujo domínio incita um estado de dispersão: "enquanto apenas sente, o homem está fora de si”. O impulso-forma, por sua vez, visa ao ser absoluto do homem, sua natureza racional. Enquanto o impulso-matéria é a receptividade às impressões procedentes do mundo externo, o impulso-forma é a razão que introduz ordem e lei no caos da percepção, sistema na experiência: "Não mais estamos no tempo durante esta operação, mas é o tempo que está em nós com toda a sua seqüência infinita" ${ }^{172}$. O primeiro impulso pauta-se na tríade natureza-multiplicidade-sentimento. $\mathrm{O}$ segundo, na tríade razão-unidade-consciência. Um constitui o caos e vive da modificação. O outro fornece leis e busca harmonizar a diversidade das aparências. O "homem estético" inventa uma ordem para seus objetos. Para que comprove sua liberdade, ele precisa "formar o informe", passar da livre seqüência de idéias à forma livremente concebida, despertar do torpor sensível, pensar a natureza ao invés de ter com ela uma relação de mero "contato imediato". O homem livre, para Schiller, almeja um princípio de enformação, enquanto "as almas frouxas são as que mais se entregam ao livre fluxo das imagens".

Por ser o mundo extensão no tempo, modificação, a perfeição [da faculdade sensível] que une o homem e o mundo deverá ser a maior mobilidade e corporeidade possíveis. Por ser a pessoa o perdurável em meio à modificação, autonomia e intensidade máximas deverão ser a perfeição [da faculdade racional] que se deve contrapor ao fluxo. Quanto mais facetada se educar a receptividade, quanto mais móvel for, quanto mais superfície oferecer aos fenômenos, tanto mais mundo o homem percebe, mais disposições ele cultiva em si; quanto mais força e profundeza ganhar sua personalidade, quanto mais liberdade ganhar sua razão, tanto mais mundo ele concebe, mais forma ele cria fora de si. [...] Quando as duas faculdades se unificam, o homem conjuga a máxima plenitude de existência à máxima independência e liberdade, abarcando o mundo em lugar de perder-se nele submetendo a infinita multiplicidade dos fenômenos à unidade de sua razão. (SCHILLER, 1963)

A "forma vitoriosa", para Schiller, "repousa a igual distância de uniformidade e

${ }^{171}$ Cf. Friedrich Schiller, Cartas sobre a Educação Estética da Humanidade, São Paulo: Herder, 1963. Ver também Rudolf Steiner, Arte e estética segundo Goethe, 2a ed., São Paulo: Antroposófica, 1998.

172 Ibid, p. 71. 
confusão". Tal será a tarefa de um terceiro impulso, o "impulso lúdico": "A atuação separada dos dois impulsos acima mencionados cessa e eles confluem num só, tornando-se livres" (Steiner). O impulso lúdico produz, no artista, “obras que já em sua aparência sensória satisfazem à nossa razão e cujo conteúdo racional se apresenta simultaneamente como manifestação sensória".

O que Schiller atribui ao "impulso lúdico", Michel Mourlet e os mac-mahonistas atribuem à mise en scène. Lembremos o que foi dito na parte I: a mise en scène verdadeira, para Mourlet, deve seguir um método, uma reflexão, um princípio de enformação, mas nunca descartar a intuição do momento, a receptividade aos fenômenos, o respeito às qualidades intrínsecas da matéria. E a recíproca é verdadeira: o metteur en scène garante para o espectador o acesso direto à presença viva das coisas, mas não sem antes organizá-las no espaço cênico. Praticar a mise en scène é justamente buscar um ponto de equilíbrio entre a matéria e a forma, por meio de uma comunhão entre o sensível e o inteligível do homem. No cinema defendido pelos mac-mahonistas (Walsh, Lang, Preminger, Losey, Mizoguchi, John Ford, Cottafavi etc), a mise en scène ocupa o lugar de congruência onde o impulso-matéria e o impulso-forma se conjugam em harmonia.

Mas o que ocorre quando tal equilíbrio é desfeito e um dos impulsos prevalece consideravelmente sobre o outro? Não há mais mise en scène?

Como já deu para notar, a dupla matéria-forma nos permite remontar aos dualismos desenho-cor e plano-fluxo que abordamos no capítulo precedente. O impulso formal, por pertencer ao lado analítico e racional do pensamento, por derivar de um saber constituído, de uma ordem lógica, e por exigir "um ato de abstração em relação ao pathos do sensível", corresponderia ao desenho (na pintura) e à estética do plano (no cinema). A escola da cor e a estética do fluxo já seguiriam prioritariamente o impulso-matéria: ênfase na multiplicidade, na profusão da natureza, no caráter físico das coisas, no caos das sensações, na fluidez e no anuviamento dos contornos (em contraposição à exatidão das formas). O cinema dos fluxos, das circulações, da trama sensorial assignificante, seria assim um cinema da matéria primordial, do corpo como placa perceptiva situada abaixo do conteúdo objetivo da consciência; um cinema das sensações em bloco, da afecção, da superfície opaca dos fenômenos, da desordem empírica do mundo sensível, quiçá do informe. Ao se entregar ao impulso-matéria, esse cinema deliberadamente se colocaria muito abaixo - ou muito além daquele ponto de equilíbrio que Mourlet identificava como a finalidade da mise en scène.

Dos cineastas que trabalham nessa zona de indefinição da mise en scène, Philippe Grandrieux e Claire Denis são os que parecem mais dispostos a mergulhar - de forma 
selvagem - na confusão original da matéria.

Em Sombra, de 1998, a experiência buscada por Grandrieux - e em nome da qual ele acorre a um certo extremismo estético - é a revivência do medo primitivo que está em cada um de nós e que se exprime "quando o mundo pára de ser mundo para tomar o aspecto apavorante do lobo das fábulas de outrora. Lobo que devora os personagens, que degola cada marca de civilização, que surge do fundo das florestas" ${ }^{173}$. A primeira cena de Sombra consiste numa platéia infantil assistindo a um espetáculo que se dá no fora-de-campo. Tudo que vemos são as reações das crianças: umas riem, outras gritam, algumas estão realmente apavoradas. Depois descobriremos que tal espetáculo era a história do "lobo mau", representada num teatro de fantoches por Jean (Marc Barbé), o protagonista do filme. Ele é um homem calado, misterioso, que vara as estradas de uma França montanhosa, verde, profunda, itinerando com seu espetáculo de fantoches. No caminho, assassina as mulheres com quem transa. As vítimas são sempre prostitutas ou mulheres que simplesmente se oferecem facilmente a ele, mas o filme não fornece nenhuma causa evidente, nenhuma motivação para os assassinatos. Jean é apresentado como um serial killer totalmente opaco e impenetrável.

Num dia chuvoso, ele presta socorro a Claire (Elina Löwenshon), jovem mulher cujo carro enguiçou no meio da estrada debaixo do temporal. Claire é uma moça acanhada e virgem, logo o oposto das mulheres que Jean estrangula; ela é quase uma alegoria, um arquétipo feminino de pureza, virgindade, clareza, um símbolo de luz, como seu próprio nome já indica. Mas sua presença no filme não significa que o personagem de Marc Barbé será encaminhado para a redenção e a purificação. Claire e Jean desenvolvem uma relação ambígua, indefinível. Mesmo o fato de ele poupar a vida dela perto do final do filme, após transarem, não significa que sua "doença" terá sido curada - numa cena mais à frente, ele estrangula uma outra mulher no meio da floresta, dando a entender que o ciclo de mortes continuará. O personagem de Jean também é arquetípico, não possui "fineza psicológica": "ele é dado como um bloco de infância, um bloco de sensações amputado dos outros homens" ${ }^{174}$. Somente no epílogo, composto por uma sucessão de travellings mostrando as pessoas aguardando a passagem do Tour de France $^{175}$ à beira de uma estrada no meio da montanha, uma ordem social é explicitamente inscrita no filme, revelando seu "contracampo absoluto", o mundo exterior das pessoas comuns em seus lazeres comuns.

Sombra pode ser visto como um mergulho nas camadas mais antigas da consciência,

173 Antoine de Baecque, "La pe ur du loup", Cahiers du Cinéma n ${ }^{\circ}$ 532, fevereiro de 1999.

174 Phillipe Grandrieux, "Le monde à l'envers", entrevista aos Cahiers du Cinéma no 532, p. 39.

175 Famosa maratona ciclística disputada anualmente na França, no mês de julho. 
em cujo fundo se encontra "um magma onde se lêem ainda as rupturas originais e se vêem já as cicatrizes de um enxerto: o pavor desses corpos e dessas paisagens vindos de alhures, que permanecem estranhos e, no entanto, se imiscuem em nós" ${ }^{" 176}$. A narrativa do filme, embora linear, é repleta de elipses e de pontos obscuros, compondo uma trama um tanto lacunar e picotada, como se ela partisse de uma consciência fraturada por traumas de infância.

A estratégia visual de Grandrieux é fundada na instabilidade e na provisoriedade. Num dos momentos mais intensos do filme, Claire e Jean vão a um baile. Ela fica bêbada e começa a dançar expansivamente. Um homem se aproxima e a assedia, querendo tirar proveito de seu estado alcoólico. A câmera está na mão, como na maior parte do filme. Aqui, ela interage ainda mais com a cena: participa, se move entre os corpos, treme, desfoca, reenquadra. $\mathrm{O}$ homem convence Claire a ir com ele e um amigo para o apartamento deste último. Jean vai também. Lá, a cena se torna mais lânguida, mais torporosa, um conjunto de ações no limiar do ilegível, banhadas na penumbra. Os eflúvios etílicos transbordam dos personagens para a câmera, a luz, a ambientação, o som (este, aliás, é acometido por vibrações, misturas ou abafamentos correlatos às perturbações visuais recorrentes no filme). Os atores se farejam, se tocam, se repelem. Grandrieux trabalha com um espaço essencialmente tátil, construído a partir não de um ponto de vista ou de um ponto de fuga, mas de um ponto de tangência. $\mathrm{O}$ plano não possui um centro geométrico, pois se mede antes pela presença ou ausência de um contato físico entre os seres, pelo pedaço de ar que os aproxima ou os afasta, por toque ou repelência. A distância focal é constantemente reconfigurada em função das relações mutáveis entre os corpos. A cena não segue uma decupagem no sentido técnico, mas modula-se a partir de uma distribuição da energia momentânea de seus elementos, distribuição por vezes desigual, provocando ápices e desníveis abruptos. O estranho ritual de acasalamento que se desenrola na casa do homem desconhecido culmina na violência: quando os dois homens tentam abusar sexualmente de Claire, já inebriada o suficiente para não saber reagir (nem saber se quer ou não reagir), Jean intercede e é espancado por eles.

A repentinidade dos atos é uma das marcas do filme. Está bloqueado o processo de "enlaçamento" ou "captura" da energia que flui para dentro da cena, portanto não há passagem do estado de fluxo livre para o estado de repouso ou acabamento. Tudo é agitação e instabilidade. Trata-se, para Grandrieux, de "filmar primitivamente a pulsão primitiva", filmar as pulsões em estado bruto. Os impulsos provenientes das pulsões não passam pelo tipo de processo nervoso que trabalha com energia fixada e presa, e sim pelos processos que operam com energia livre e móvel. Esse tipo de processo, que Freud chama de "processo psíquico

176 Baecque, "La peur du loup". 
primário", é o que se encontra em ação no inconsciente, diferente do "processo psíquico secundário", que vigora em nossa vida normal de vigília ${ }^{177}$. Como todas as moções pulsionais [Triebregungen] iniciam seu trabalho nos sistemas inconscientes, elas obedecem ao processo primário, que corresponde às cargas de investimento livremente móveis, enquanto o processo secundário corresponde às modificações que se produzem nas cargas de investimento presas. Os processos primários são os mais antigos, remontam ao início da vida psíquica. E é de lá que Grandrieux extrai seu cinema, das pulsões mais arcaicas. Como disse Antoine de Baecque, Sombra é um filme que "vem de longe": resíduos distantes de medos infantis se mostram sob a máscara translúcida das angústias contemporâneas. É como se Grandrieux trabalhasse o conteúdo psicológico de seu filme num estágio anterior à intervenção que o aparelho psíquico faz sobre o material oriundo do inconsciente para dar-lhe uma forma apreensível pela percepção, organizá-lo, dar-lhe um mínimo de inteligibilidade (algo ligado ao processo secundário e à consciência). Sombra pertence prioritariamente ao domínio do inorganizado, do inapreensível, do ininteligível, onde circula energia psíquica não-ligada, não-fixada, incapaz de chegar a um nivelamento interno de suas tensões. O princípio estético geral de Philippe Grandrieux é a saturação, expressa, inclusive, pelo próprio modus operandi de Jean: ele sufoca suas vítimas, exaure seu oxigênio e sua energia vital da mesma forma que o filme exaure o espectador. Este é "abertamente colocado à prova, prova sensorial: todos os seus sentidos são convocados e saturados pelas perturbações, sub-exposições, sonoridades, abafamentos, violências que povoam o filme. Prova quase narrativa em seguida, pois não há descanso entre uma morte e outra, uma agressão e outra" (Baecque). Os processos não capturados e não enlaçados, ou seja, os processos primários nos quais o filme embarca, produzem sensações muito mais intensas em ambas as direções - prazer e desprazer - do que os que operam com energia capturada e enlaçada.

Falei bastante em pulsão no parágrafo acima. Uma pulsão nada mais é que "uma força impelente [Drang] interna ao organismo vivo que visa a restabelecer um estado anterior que o ser vivo precisou abandonar devido à influência de forças perturbadoras externas" ${ }^{178}$. No final de Sombra, Jean se deita ao pé de uma árvore e fica ali encolhido, em posição fetal, como "um homem que voltou ao estado de animal-criança". Mais ainda: Jean parece querer se misturar à terra, fazer uma regressão radical, simbolizando "a aspiração mais universal de todo ser vivo de retornar ao estado de repouso original do mundo inorgânico" (Freud). "O assassino de Sombra é feito dessa matéria, vegetal, terrosa, aquosa"; "Jean é um animal que,

177 Cf. "Além do princípio de prazer", in Obras Psicológicas de Sigmund Freud-Volume 2: Escritos sobre a Psicologia do Inconsciente, Rio de Janeiro: Imago, 2006.

178 Idem. 
ao fim, retorna à sua toca, mineral que se funde às pedras, às árvores e ao verde escuro, úmido, do húmus original" (Baecque). O filme tem uma proximidade muito grande com os espaços selvagens, com as florestas ensombradas e úmidas, com a carne crua da natureza, as consistências da terra e as texturas da pele. O gesto fundamental de Grandrieux é "trabalhar diretamente a matéria natural, as florestas, as montanhas e a luz". Os corpos se misturam às cores da natureza, "seu relevo, seus reflexos, seus vazios, suas plenitudes e suas escuridões". No limite, o filme faz o mundo regredir a uma lama originária onde a consciência ainda não se individuou, onde o homem ainda não se distinguiu das coisas e não encontrou no espelho da consciência os objetos da realidade exterior, ficando perdido numa subjetividade caótica e primitiva $^{179}$.

A única coisa que Grandrieux entrega à percepção concreta do espectador é, de um lado, a matéria humana condensada no arquétipo, e, do outro, a matéria bruta e ruidosa da imagem, sua violência icônica. O par arquétipo-sensação de certo modo "curto-circuita a possibilidade de uma apreensão consciente e crítica do objeto" ${ }^{180}$. Para provocar no espectador a sensação de consciência obnubilada, ou mesmo de inconsciência, e situá-lo assim num espaço indeterminável, Grandrieux recorre a enquadramentos sempre parciais e incompletos. Esses enquadramentos que nunca garantem a apreensão completa e clara de nenhum de seus conteúdos conseqüentemente criam um estado de expectativa e temor, de imantação ao desconhecido, o que é de todo coerente com a proposta de Grandrieux de chamar a atenção para os objetos latentes da consciência e, se possível, estimular o medo alojado no inconsciente, revolver o lodo infernal trancafiado no fundo do imaginário.

Há também uma recorrência de primeiros planos, alguns tão próximos do corpo do ator que vislumbram o limite a partir do qual uma imagem de algo não é mais possível, pela falta da distância mínima que a constitui. É o que ocorre, por exemplo, na seqüência mais abstrata do filme, quando uma paisagem vista da janela do carro em movimento de repente se transforma numa sucessão de imagens tremidas, riscadas, borrões incognoscíveis, uma detonação do espaço figurativo, uma "catástrofe" do visual, supressão brusca da perspectiva e do relevo geométrico em proveito de formas originadas de emaranhamentos, misturas, entropia. O filme, naquele momento, se torna uma pintura de Jackson Pollock em celulóide. A alucinante seqüência termina com a câmera se distanciando lentamente do topo da cabeça de Jean (como se estivesse saindo de dentro da cabeça dele), que está ao volante do carro, com o

\footnotetext{
179 É interessante, a esse respeito, ler "o caso de Roberto" narrado por uma discípula de Lacan (cf. "O lobo! $O$ lobo!", em O Seminário - Livro 1: Os escritos técnicos de Freud, $2^{\mathrm{a}}$ ed., Rio de Janeiro: Jorge Zahar Editor, 2009, pp. 122-145).

180 Patrice Blouin, Cahiers du Cinéma nº 573, novembro de 2002.
} 
vento balançando seus fios de cabelo. Duas coisas se depreendem: primeiro que, naquele movimento de recuo que interrompe as imagens abstratas e introduz um mínimo de inteligibilidade e clareza no campo visual, a câmera - especulemos - está saindo de um breve mergulho que havia feito no cérebro do personagem; segundo que, nesse mesmo recuo, a câmera completa seu circuito de diluição das fronteiras entre o próximo e o distante, entre o grande e o pequeno. Há uma perda da perspectiva e uma desaparição das figuras, que cedem lugar a traços, a trajetos indeterminados da cor, sugerindo uma moção de conteúdos psíquicos descontrolada (a descarga pulsional?) e remetendo ao mouvement-fou da pintura moderna. Não há mais distância ou horizonte, mas simplesmente um campo visual sem começo nem fim, fora do tempo. A imagem assim obtida desrealiza os contornos do legível, passa a operar num nível molecular dos elementos plásticos, provocando trajetórias de colisão no decurso das quais as cores e as matérias interagem e se transformam.

Uma outra seqüência, a mais bela do filme, segue uma composição diferente, mas uma mesma lógica de incidir diretamente sobre a matéria sensível do cinema (a luz, os corpos, a montagem, o ritmo, o som). Jean, Claire e sua irmã Christine (Géraldine Voillat) estão num lago situado entre pedras, árvores e montanhas. Christine, ao contrário da irmã, é atirada e extrovertida, e começa a nadar pelada no lago. Ocorre então um plano que mostra Jean de costas, observando Christine do alto de uma pedra - o predador avalia sua presa. O plano o enquadra apenas do ombro para cima. $\mathrm{O}$ fundo da imagem é a água do lago refletindo os raios solares. Jean está em contra-luz, os contornos do seu corpo recortam uma zona de sombra na superfície cintilante da água. O lugar do personagem na planimetria da cena está estabelecido, e o todo da composição funciona como "um plano físico e mental de luz"181. Jean e Claire também entram na água depois. Christine se afasta em direção a uma das margens do lago, distante do local onde Claire se encontra. Jean vai atrás de Christine. À beira do lago, ele a ataca, parte para cima dela num misto de erotismo e instinto assassino. As mãos de Jean, repletas de lama, apertam o pescoço de Christine, cuja pele parece absorver a terra molhada numa fusão de matérias. Claire, que lá de longe havia percebido que algo de errado acontecia, chega para salvar Christine. Com um grito, ela afugenta Jean: "sua presença vocal basta para enxotar o homem, sem precisar de outra ameaça"182. Ele sai como um animal assustado, vai andando para o meio do lago, até ficar parado à distância, com água pela cintura, de costas para as meninas e para a câmera, numa posição arqueada, combalida. Há um grande plano geral dele rodeado pela Natureza, besta-fera solitária na imensidão. Ao final da seqüência,

181 Cf. Philippe Grandrieux, "Baignade interdite", Cahiers du Cinéma nº 532, fevereiro de 1999, p. 43.

182 Idem. 
uma panorâmica segue o relevo das rochas, deixa-se ritmar pelo vento nas árvores, perfaz as ondulações da natureza, ressaltando a fisicalidade do filme.

Sombra coloca o espectador do lado do protagonista, não necessariamente para legitimá-lo, compreendê-lo ou desculpá-lo, nem para se purificar graças a essa travessia do horror. Grandrieux tão-somente propõe que o espectador partilhe a experiência do personagem, "essa desagradável sensação de ser uma espécie de monstro, de ser obrigado a viver na sombra, e de carregar essa culpa como um fardo"183. Ele mostra o "assombramento da natureza humana", um "mal-estar" que é a substância mesma do filme. A imersão sensorial que ele estimula tem por finalidade o comportamento que Claire exibe numa cena num quarto de hotel, onde ela começa a remexer as coisas de Jean e encontra uma fantasia de lobo, a qual ela veste. É isso que Grandrieux pede a seu espectador, ou seja, que ele aceite vestir a pele do lobo $^{184}$.

Tal experiência radical de imersão e de alteridade pode ser vista também nos filmes de Claire Denis (cujo Trouble Every Day, aliás, guarda lá suas semelhanças com Sombra). Há um aspecto neo-primitivo no olhar de Denis que a aparenta a Grandrieux: um gosto pela selvageria das coisas brutas, pelas pulsões arcaicas, pela radiação silenciosa e quente de uma terra originária, de um mundo ancião que continua agindo debaixo dos tecidos do mundo atual. Seu cinema igualmente busca desestabilizar fronteiras - entre consciente e inconsciente, natural e antinatural, real e imaginário, organismos vivos e matérias inanimadas. Nenhuma fronteira é permanente, muito menos aquela entre o homem e as outras espécies (pensar no devir-animal de seus personagens). Ela filma a energia trocada pelos corpos na respiração, e sua captura do real inclui uma periculosidade, um risco.

O Intruso (2004), seu filme mais enigmático, começa com um breve plano frontal da atriz Katia Golubeva, que, envolta na escuridão, acende um cigarro e olha para a câmera enquanto um texto é recitado por ela em off: "Seus piores inimigos estão no interior, escondidos na sombra, escondidos no seu coração". Em seguida, vêm os créditos iniciais (mas não o título, que só aparecerá alguns minutos depois). O momento seguinte é o que se pode chamar de uma primeira "cena" do filme: Antoinette (Florence Loiret-Caille), uma jovem policial acompanhada de um cão farejador, inspeciona um carro que foi parado pela guarda

${ }_{183}$ Ver José Carlos Avellar a respeito de um outro filme, Ato de Violência (Eduardo Escorel, 1980), "L'entrée des ouvriers dans l'usine Lumière", in Cinéma brésilien 1970-80: Une trajectoire dans le sous-développement, Locarno: Editions du Festival international du film de Locarno, 1983.

184 "Eu creio sinceramente que não existe um ato inumano, por mais monstruoso que ele seja. O homem está atrelado à sua espécie (...) Jean não é situado num terreno social ou psicológico, ele não é um perverso. Ele não sente prazer no momento em que mata. (...) Eu pensei, portanto, que ele deveria matar, mas não torturar, não fazer mal. Ele mata porque isso é instintivo, não pensado" (Phillipe Grandrieux, "Le monde à l'envers", p. 39). 
aduaneira na fronteira entre a França e a Suíça. O cão encontra um recipiente suspeito. $\mathrm{O}$ homem é detido. Antoinette faz carinho no cachorro como recompensa pelo "bom trabalho", para usar aqui o título de um dos filmes de Denis (Beau Travail, 1999). A noção de fronteira trabalhada pelo filme já está aí exposta: não só a fronteira que demarca territórios, mas a fronteira entre uma atividade e outra (entre a lei e a contravenção, por exemplo), ou simplesmente entre o Um e o Outro. Quando Antoinette pede que o motorista desça do carro para que o cachorro o inspecione, ela nada mais faz do que invadir o espaço do outro, tomando o cuidado de frisar para o homem que a inspeção é "rotineira". É a primeira cena de intrusão do filme.

A segunda vem logo depois: Antoinette chega em casa do trabalho, tira seu uniforme, observada com ternura pelo marido, Sidney (Grégoire Colin), que cuidava dos dois bebês do casal antes dela chegar. Enquanto ela lava a louça do jantar, Sidney começa a seduzi-la com uma voz sussurrante, hipnótica. Ele se aproxima de Antoinette e começa a tirar sua roupa, com a câmera bem perto do corpo da moça, partilhando da intimidade do casal. Assim que ocorre a penetração e eles começam a transar, uma das crianças chora e Denis corta para um plano-detalhe da babá eletrônica, seguido de um plano do bebê no berço. Deste, corta para uma cena que mostra um grupo de pessoas se camuflando no breu noturno para cruzar a fronteira ilegalmente. Novas fronteiras e novas intrusões, portanto, entram em jogo nessas duas cenas: fronteira entre corpos a ser "desrespeitada" pela intrusão de um corpo no outro (o sexo); fronteira entre as esferas profissional e doméstica, que se interpenetram (a câmera enfatiza a ação de Antoinette tirando sua arma da cintura e a depositando num móvel do apartamento; no caso de Sidney, o espaço domiciliar se confunde a um lugar de trabalho, pois ele é claramente apresentado no filme como um "dono de casa", alguém cuja tarefa é cuidar dos filhos e da manutenção do lar); fronteira entre o prazer e o dever (a criança chora e interrompe o sexo, chamando os adultos à responsabilidade familiar); fronteira entre países clandestinamente atravessada na calada da noite (essa idéia de uma circulação ilegal de corpos já havia sido o mote de um filme de Claire Denis em 1994, Noites Sem Dormir).

O protagonista de O Intruso, Louis Trebor (Michel Subor), só aparece com dez minutos de filme. Ele está nu no meio da floresta, deitado ao pé de uma árvore, acompanhado de seus dois cachorros - "nu entre os lobos", poderíamos dizer. Alguém o espia entre os arbustos, alguém que não aparece ainda, mas cuja presença já se faz sentir, primeiramente pela inquietação dos cães - que olham ao redor como a procurar o sinal visível do inimigo cujos passos já foram ouvidos e cujo suor já foi farejado -, depois por um plano filmado do ponto de vista do voyeur, ou do assassino em potencial (um plano de filme de suspense): o 
campo visual está parcialmente encoberto por galhos e folhas, como se a câmera estivesse escondida atrás de um arbusto, inscrevendo esse olhar na posição de um observador que quer ver sem ser visto (a câmera treme um pouco mais que nos outros planos, dando uma tensão corporal a esse olhar).

Ainda nessa sua primeira cena no filme, Louis Trebor aparece nadando num lago. Ele dá algumas braçadas e começa a passar mal, sentindo alguma forte dor no peito. Louis sai da água e fica deitado na areia, tentando se recuperar da dor. Sua mão aperta um punhado de terra úmida, espreme a areia entre os dedos, em planos fechados que bem poderiam estar em Sombra (o contato íntimo com a matéria da natureza é um aspecto forte também neste filme). Só então vemos a figura de seu observador clandestino, uma silhueta que se dissimula entre as árvores, perto do lago. É o olhar intruso, que não terá apenas um dono ou um corpo fixo no qual se alojar, mas que será um olhar móvel, movente, olhar que não cessará de tencionar, dimensionar e, às vezes, assombrar o filme.

Trebor precisa passar por um transplante cardíaco, cirurgia que deixa uma enorme cicatriz em seu peito. Durante o período de convalescença, ele sofre com a rejeição ao novo órgão provocada por seu sistema imune. Expressa-se, desse modo, a figura de intrusão mais radical do filme: um órgão que é arrancado de um corpo e embutido em outro por um procedimento a que os próprios médicos chamariam invasivo. A tirar pela síndrome de rejeição que vem na esteira da cirurgia, o coração que Trebor recebe é como um coração selvagem, um animal arrancado de seu nicho e jogado numa jaula (a caixa torácica formada pelas costelas) da qual quer agora fugir ${ }^{185}$.

Trebor mora no meio da floresta, num casebre, em companhia apenas de seus cachorros, sendo visitado por sua amante, uma farmacêutica de origem oriental. Trebor tem um passado obscuro, um envolvimento com transações ilícitas. Vive à margem da lei dos homens e agarrado às leis brutais da natureza. Um personagem opaco e misterioso. Sua relação com os outros personagens é ambígua. Com Sidney, que é seu filho, ele demonstra não mais que desprezo. Com a criadora de cães (Béatrice Dalle), um fascínio diluído na distância que ela prefere manter. Com a personagem de Katia Golubeva, um misto de cumplicidade e antagonismo: é ela quem o ajuda a conseguir um novo coração, mas é ela também quem o persegue o filme todo como se fosse um anjo da morte. Num dos pesadelos de Trebor, ela o amarra a um cavalo e o arrasta pela neve. Quando ele diz: "Eu já paguei pelo coração", ela responde: "Você nunca pagará o suficiente". Algo de muito grave, portanto, ele

${ }^{185}$ Será o coração da "mulher selvagem" que vemos em algumas passagens do filme? Essa personagem constitui o elemento mais inescrutável do filme; as cenas em que ela aparece são as mais inexplicáveis, estabelecendo vínculos muito obscuros com o restante da narrativa. 
deve ter feito a ela no passado, e uma vingança pode estar a caminho. Claire Denis define Michel Subor como "um buraco negro no cosmo: ele suga toda a energia que está ao redor". Podemos extrapolar a definição ao seu personagem.

$\mathrm{Na}$ parte final do filme, Trebor, que um dia foi marinheiro, vai para o Taiti à procura de um filho que lá teria deixado, e que nunca chegou a conhecer. Para localizar o suposto filho, pede ajuda a Henri, um antigo amigo que reencontra. Henri, no entanto, vai à procura não do filho verdadeiro, mas de um filho substituto: ele monta uma banca de jurados recrutados no vilarejo para receber e avaliar uma série de candidatos ao papel de filho de Louis Trebor. Os candidatos, sempre filmados em plano frontal, semi-documental, extremamente cru em sua dramaturgia (o enquadramento e a luz são simplificados ao máximo e nenhum ator é profissional; Denis investe no aspecto naïf das apresentações), vão sendo descartados por não baterem fisicamente com o perfil exigido, por não terem o physique $d u$ rôle. Essa inusitada cena de "casting" guarda uma enorme complexidade:

A cena vale ao mesmo tempo como uma teatralização do trabalho da imaginação ou da idealização e como uma dramaturgia da arte e dos artefatos das estruturas de parentesco. Nenhum dos jovens corresponde à expectativa de uma semelhança, a única expectativa possível na ausência de qualquer outro critério. [...] A semelhança, signo ou assinatura da natureza, é inencontrável. [...] Toni, o rapaz que terminará por assumir o lugar do filho, não o fará senão por sua própria iniciativa $[\ldots]$ Ele recusa o dinheiro, não entra nesse circuito do (falso) valor geral, e é um surfista: outra espécie, época e estilo de "marinheiro". (NANCY, 2005)

O circuito de filiação estabelecido pelo filme se fecha quando Sidney aparece morto no Taiti, surgido praticamente do nada, quase que trazido pelas ondas do $\operatorname{mar}^{186}$. Trebor vai reconhecer o corpo no instituto médico legal. É quando Denis atinge essa imagem que sintetiza o trajeto sanguíneo do filme, essa imagem cruel e terrível do peito de Sidney com uma cicatriz idêntica à de Louis Trebor, seu pai. A vingança se prova mais horrenda do que Trebor poderia imaginar: o coração que ele recebeu no transplante foi o coração arrancado de seu próprio filho. O destino revela seu plano: ao ir atrás do filho bem amado, o filho desconhecido (inexistente?), Trebor provoca a morte de seu outro filho, conhecido, mas desprezado, o filho rejeitado cujo coração ele agora carrega, não sem submetê-lo a uma nova rejeição, desta vez instintiva, imunológica. O próprio Trebor havia dito para Katia Golubeva:

${ }^{186}$ No primeiro corte do filme, que competiu em Veneza e tive a oportunidade de ver no Festival do Rio de 2004, havia de fato um plano - que depois ficou de fora da versão final - que mostrava o corpo de Sidney abandonado numa praia taitiana, com as ondas batendo nele insolentemente, dando essa impressão de que sua morte veio através do mar, do mesmo movimento fluido e imanente que marca a dinâmica geral do filme. 
“eu quero um coração jovem, não de velho, não de mulher, um coração de homem”. Ela atendeu ao pedido dele, encontrando aí a ocasião de sua vingança.

$O$ Intruso acaba por se revelar uma tragédia. Mas uma tragédia sem pathos, sem frêmito, sem clímax dramático, sem a representação exata do evento desastroso e doloroso. $\mathrm{O}$ narrador está cegamente imerso na experiência, não tem a distância necessária para "contar histórias" e, a partir delas, estimular emoções na platéia. A diluição do drama é acompanhada de uma fascinação com a "flutuação generalizada", com a sensação de mobilidade. O lugar da cena não se apresenta com clareza, a narrativa tampouco. Nenhuma cena é decupada segundo uma necessidade pragmática do enredo, ou segundo uma preocupação com a fluência dramática do conjunto. Esses critérios ou valores são substituídos por um olhar vagante, uma atenção dispersa, uma planificação da narrativa que se prova sensível à aleatoriedade e à memória lábil das coisas. Numa montagem elíptica e pouco didática, O Intruso vai das florestas da França a um banco na Suíça, dali para a região portuária de Pusan (Coréia do Sul), de lá para os mares do Pacífico e então de volta para o inverno no hemisfério norte. Por meio tão-somente de um corte seco, o filme pode transportar seu espectador de uma praia ensolarada para um bosque enevado - uma verdadeira intrusão mútua dos tempos e dos lugares. Denis mostra os contrastes entre os dois hemisférios menos para criar rupturas do que para nos lembrar de que a Terra é redonda e, por conseguinte, tudo nela é continuidade, mistura, circulação, passagem, fluxo. O olhar é convidado à errância, à contemplação sem vínculos; ele se perde na paisagem, no oceano das sensações. Há seqüências, mas não cenas. Em algumas dessas seqüências, Denis leva ao limite a possibilidade de um plano de cinema se apresentar como puro exercício do olhar, visão errante fascinada com as pequenas fulgurâncias do mundo (os planos mais "soltos" do filme são aquelas longas tomadas que mostram o vento balançando as fitas coloridas que enfeitam um navio no cais de Pusan). "Essa circulação permanente, esse perpetuum mobile acarreta também uma grande raridade dos interiores em meio a uma profusão de exteriores amplamente abertos”, afirma Jean-Luc Nancy, autor do ensaio homônimo no qual O Intruso é livremente inspirado. Ele assim define a diferença entre o livro e o filme ${ }^{187}$ :

O livro consigna somente uma breve reflexão sobre aquilo que um transplante de coração pode representar quanto a uma consciência contemporânea da identidade. O "intruso" designa aí uma alteridade irredutível e, entretanto, incorporada, sendo que o transplante forma apenas uma figura no seio de um processo mais geral de transformação que afeta tudo o que se crê poder designar como

187 Ver "L'Intrus selon Claire Denis", em Remue, primavera de 2005, disponível em http://remue.net/spip.php? $\underline{\text { article679, }}$ acessado em 16/6/2010. 


\begin{abstract}
"natural" e que entra no reino geral do que em outra ocasião eu nomeio nossa ecotecnia (écotechnie). Nada a ver, portanto, com o roteiro complexo e até mesmo labiríntico de um filme no qual um homem perseguido e com o coração debilitado passa por uma cirurgia a fim de prosseguir na busca por um filho abandonado. Nada a ver, e no entanto... basta que eu justaponha os dois argumentos assim resumidos do livro e do filme para fazer nascer uma luz. (NANCY, 2005)
\end{abstract}

A idéia de "um processo mais geral de transformação que afeta tudo o que se crê poder designar como 'natural"' é bastante fértil, e podemos associar-lhe o fato de que assistimos hoje à abolição daquela que talvez seja a última das fronteiras: a do natural (como aquilo que se sustenta/produz a si mesmo) e do artificial (como aquilo que precisa ser produzido); vemos o artificial se auto-produzindo e o natural sendo produzido.

$O$ Intruso é um filme sobre as possibilidades de habitar o mundo e se transportar dentro dele. Além dos deslocamentos de Trebor por terra, ar e mar (sem falar em seus deslocamentos virtuais), Denis faz questão de ressaltar também os traços que indiquem que, antes do filme, um homem - às vezes o próprio Trebor - já esteve ali naqueles solos, naquelas paisagens, naqueles territórios. Na já citada cena em que Trebor pega um punhado de terra com a mão enquanto passa mal à beira do lago, há um detalhe que não se deve menosprezar: em meio à areia umedecida, ele acha uma guimba de cigarro (signo de sua própria doença?). Não há paraíso perdido em $O$ Intruso, não há paisagem virginal: todo espaço traz a marca de uma presença anterior do homem. $\mathrm{O}$ acesso direto à Natureza inexiste; não se pode saber o que ela é sem a intervenção humana. Isso afasta a idéia de uma contemplação da natureza em estado inocente, como paraíso perdido da percepção, ou protegida da própria potência do homem. "O 'mundo humano' é o meio e a pátria dos nossos pensamentos" (Merleau-Ponty). Mesmo na parte final do filme, quando Trebor vai a uma ilha no Sul do Pacífico (a ilha deserta, palco da solidão por excelência, da natureza pura, imemorial), pesa a sensação de um espaço já antes explorado, tanto que Claire Denis recupera algumas imagens lá filmadas por Paul Gégauff em 1962, para o filme inacabado Le Reflux, no qual Michel Subor também atuava. A seqüência de Le Reflux enxertada em O Intruso, além de operar mais um transplante dentro do filme (desta vez de ordem textual), reforça a idéia de que aquele espaço já foi filmado anteriormente da mesma maneira que está sendo filmado agora, como se houvesse uma memória antropológica dos gestos determinando que cineastas diferentes em tempos diferentes repitam os mesmos planos diante das mesmas paisagens (Denis, nesse sentido, poderia ter voltado ainda mais no tempo e mostrado cenas de Tabu, a obra-prima de Murnau e 
Flaherty de 1931). Existe sempre alguma coisa que veio antes, e é preciso fazer a arqueologia dessa anterioridade.

O que Denis filma, em última instância, é aquela camada concêntrica que surgiu na Terra junto com o homem: a noosfera, "a maravilhosa cobertura de matéria humanizada e socializada que, a despeito de sua incrível tenuidade, tem de ser positivamente considerada a mais marcadamente individualizada e a mais especificamente distinta de todas as unidades planetárias até agora reconhecidas" ${ }^{\prime 188}$. Essa camada que recobre a superfície terrestre com todos os produtos da ação humana no mundo é "mais vibrante e mais condutora, num certo sentido, do que todos os metais; mais móvel do que todos os fluidos; e mais expansiva do que todos os vapores". É uma camada "pensante", sob e sobre a qual correm os diversos microfilamentos narrativos do filme, seus feixes de informações incompletas e inarticuladas, ritmados por um pensamento "surpreso e sincopado - um pensamento ocupado não de suas 'idéias', mas de seu movimento, de sua velocidade e de seu deslocamento" (Nancy). Na superfície vibrante do mundo, nessa camada física delgada e frágil que é a noosfera, Claire Denis encontra uma matéria ultra-magnetizada, um meio hiper-condutor. Tudo é movimento, intensidade, potência.

Nancy discorre longamente sobre "todo esse conjunto móvel, fluido e agitado" de que o filme se compõe:

Deslizamentos de trenó ou de bicicleta, deslocamentos dos carros, corridas dos cães, trajetos dos aviões e dos barcos, deambulações, deslize do surfista: o movimento do filme, sua cinestesia (kinesthésie) é um movimento de movimentos e de sensações de movimentos. [...] O tempo conta em todos os sentidos, ele é precioso (como o relógio) como tempo do retorno e como tempo da busca, como tempo de memória e tempo de espera, como tempo de tensão e de relaxamento. Como o relógio comprado [por Trebor] em Genebra, no coração da indústria relojoeira de precisão e do sistema bancário reunidos, o tempo conta absolutamente e não conta de todo: cada instante é precioso, mas todos os instantes somem na equivalência geral do deslocamento.

De modo paralelo, o tempo é mecânico, ajustado, contado semelhante à pulsação regular de um coração, essa maquinaria à qual somente importa o batimento - e ao mesmo tempo ele é contínuo e fluido, variável, elástico e imprevisível. É assim que se deve "apreciar a beleza do movimento" [como diz a vendedora do relógio a Trebor]. A duração a um só tempo se levanta e se suspende, ela não pára de ser esburacada ou desarticulada por elipses, por flash-backs mal delimitados ou por simultaneidades

${ }^{188}$ Cf. Stephen Jay Gould, "Nosso lugar natural”, in A galinha e seus dentes, Rio de Janeiro: Paz e Terra, 1992. O conceito de "noosfera" citado por Gould é de autoria do fenomenólogo, teólogo e paleontólogo francês Pierre Teilhard de Chardin, em sua obra O Fenômeno do Homem. 
incertas. [...] Todo o movimento do filme, toda sua cinética no sentido próprio se dá na passagem. $\mathrm{O}$ intruso é tanto aquele que passa quanto aquele que irrompe. Sua irrupção se acompanha de sua partida, ambas são indiscerníveis: é assim que ele permanece estrangeiro em sua passagem, e não pode ser identificado nem assimilado a um lar. (NANCY, 2005)

$O$ Intruso, portanto, coloca-nos numa situação de deslocamento e passagem constantes. A indeterminação prevalece como princípio. A realidade e seus fantasmas são apresentados como uma única massa inextricável, impedindo que os conjuntos espaciais, temporais e afetivos se articulem em termos distintos e identificáveis. Estamos apanhados nos estágios mais confusos da percepção e não conseguimos impor forma e sentido ao caos sensível.

Claire Denis, assim como Philippe Grandrieux, é uma artista mergulhada na sopa de matéria que antecede a forma. Na matéria reside o caos originário, a ilimitada potência do não-ser. Cada plano de $O$ Intruso ou de Sombra nada oferece senão a incidência de um ponto de vista circunstanciado sobre o fluxo onde reina a indistinção primeira das imagens e das coisas. Há nesses filmes um tropismo pelas qualidades primárias da matéria análogo àquilo que Clement Greenberg descreveu a propósito da escultura moderna: "a figura de pedra parece estar prestes a recair no monolito original, a peça fundida parece se reduzir e se homogeneizar numa volta ao magma original de que brotou, ou tenta lembrar a textura e a plasticidade da argila em que antes foi trabalhada" ${ }^{189}$. A consistência e o estado da matéria acabam presidindo a forma. Na extremidade da imagem-tempo, nas conseqüências últimas de toda uma concepção moderna e mesmo pós-moderna do cinema, o que há para ver é a desrealização da forma e a reimersão na matéria.

Talvez devamos nos fazer aqui a mesma pergunta que Serge Daney se fez ao final de seu famoso ensaio "A rampa (bis)" ${ }^{190}$ : então, o barroco? Pois há um limite no barroco, um

189 "Rumo a um mais novo Laocoonte", In COTRIM, Cecilia e FERREIRA, Gloria, Clement Greenberg e o debate crítico, Rio de Janeiro: Jorge Zahar, 2001, p. 57.

190 Ver A rampa, pp. 229-234. Nesse texto de 1982, Daney descreve três fases da cenografia no cinema. A primeira, que pertence ao cinema clássico, é a cenografia da profundidade, ou melhor, da ilusão de profundidade. "O título de um filme americano de Fritz Lang resume bem o que é essa cenografia e o desejo que ela carrega: Secret Beyond the Door [O segredo da porta cerrada]. Desejo de ver mais, de ver por trás, de ver através" (p. 229). A cenografia clássica traz a promessa de que as imagens guardam um segredo (ou um horror, ou uma coisa qualquer) a ser revelado. É justamente essa promessa, esse pacto de revelação com o espectador, que o cinema moderno irá quebrar, afirmando que "a imagem do cinema é uma superfície sem profundidade". A segunda cenografia, moderna, bloqueia portanto a pulsão escópica: "O olhar não se perde mais entre obstáculo e profundidade, mas é devolvido pela tela como uma bala por um muro" (p. 232). A imagem funciona como superfície, "sem profundidade simulada", "um espelho no qual o espectador captaria seu próprio olhar como aquele de um intruso, como um olhar a mais". Já o terceiro tipo de cenografia é aquele que se desenvolve na passagem dos anos 1970-80 e se identifica ao "momento maneirista" sobre o qual já falamos (embora Daney em nenhum momento utilize o termo "maneirismo" em seu texto, ele está 
ponto culminante que o próprio Bazin comenta em seu texto sobre cinema e pintura ${ }^{191}$ :

[Essencialmente] o quadro tem por missão, senão criar, ao menos sublinhar a heterogeneidade do microcosmo pictural e do macrocosmo natural no qual a pintura (tableau) vem se inserir. Daí a complicação barroca do quadro tradicional encarregado de estabelecer uma solução de continuidade geometricamente indefinível entre a pintura e seu muro, quer dizer, entre a pintura e a realidade. Daí também, como bem o explicou Ortega y Gasset, o triunfo do quadro dourado "nisso em que é a matéria que produz o máximo de reflexos e que o reflexo é essa nota de cor, de luz que não traz em si nenhuma forma, que é pura cor informe". (BAZIN, 1985)

A pura sensação da cor, liberta de um sentido geral condicionado pela forma e pelo contorno e acompanhada de uma problematização das noções de "borda" e "limite" do quadro, interessa sobremaneira à pintura barroca. Também na arquitetura, o barroco (em especial o barroco tardio) manifesta um certo prazer pelo raro, pelo que está além das regras: "O fascínio pelo informal começa a operar" ${ }^{192}$. O exagero da riqueza decorativa gera um efeito de dissolução das formas, podendo descambar na aparente ausência de forma. $O$ recheio decorativo é grande demais para o espaço, deixando-o transbordar sobre a moldura. A beleza e o prazer estético não se encontram mais na forma bem delineada, no ordenamento da obra, mas antes no movimento das massas: "as formas parecem mudar a cada momento pelo saltitar inquietante e seu fluxo e refluxo apaixonado". A massa bruta irrompe, ou então escorre viscosamente, sem modelação exata; tudo se desloca e o caos domina. As arestas agudas e os ângulos duros cedem lugar a um estilo caracterizado por intumescências e ondulações. As diversas partes não são mais separadas nitidamente entre si, mas se confundem. A arte da Renascença atingia "um perfeito equilíbrio entre a massa inteira e a forma que a encerra". Já no barroco, acentua-se a matéria: a moldura desaparece inteiramente ou então permanece, mas não é suficiente para conter a massa que transborda. "O barroco em nenhuma parte oferece o

abordando o mesmo comportamento estético que os Cahiers alguns anos depois chamariam de "maneirismo"): esgotado seu período moderno, o cinema não mais denuncia a ilusão da cena, tampouco é inocente a ponto de acreditar num retorno ao jogo de obstáculos e segredos da cenografia clássica; ele desenvolve uma cenografia de terceiro tipo, nem clássica nem moderna, produto de um contexto em que "o fundo da imagem é sempre já uma imagem", "uma imagem de cinema" (p. 233). A mise en scène, nesse caso, funciona como uma visita guiada ao museu da história do cinema, onde as imagens deslizam umas sobre as outras, "com delícias, com ironia". Syberberg, Coppola, Ruiz, De Palma, cada um a seu modo, seriam mestres nesse tipo de cenografia (ver, a esse respeito, a análise de Trágica Obsessão [De Palma, 1975] no capítulo anterior). Daney termina o texto se interrogando: “Então, o barroco?”. Em outras palavras: será o maneirismo cinematográfico, como foi o pictórico, uma ponte entre a superação do clássico e o advento do barroco?

191 "Peinture et cinéma", in Qu'est-ce que le cinéma?, Paris: Les Éditions du Cerf, 1993.

192 Heinrich Wölfflin, Renascença e Barroco, p. 34. 
acabamento, o apaziguamento ou a serenidade do ser, mas a agitação do devir, a tensão da instabilidade" "193. Cultiva-se uma sensação do inacabado, em oposição ao estável e determinado; "o olho não consegue encontrar repouso diante do inatingível". O detalhe, por mais rico que seja, perde o significado em meio aos efeitos de massa e movimento. O olhar mergulha na excitante desordem formal que acaba sublinhando o lado puramente sensorial da experiência. A estrutura estilística assim concebida expressa menos um pensamento do que uma atmosfera. Sente-se mais a matéria do que a estrutura interna e a articulação. Os elementos mais indeterminados tornam-se os meios propriamente ditos da expressão (um efeito de luz pode adquirir significação maior do que a forma). Apreender o objeto passa a ser menos importante que abandonar-se a uma sensação global, vaga, uma espécie de embriaguez estética - menos percepção concreta e mais atmosfera, daí um crescente interesse pela ambientação.

Ora, todas as características acima poderiam muito bem ser mencionadas para descrever os efeitos provocados pela matéria-fluxo dos filmes de Philippe Grandrieux e Claire Denis. Filmes como Sombra e O Intruso não são barrocos, definitivamente, mas trabalham aquela matéria amolecida e fluida que decorre da transformação barroca de uma matéria dura e quebradiça em outra que se reaproxima da massa informe.

A progressão narrativa, enquanto articulação de eventos dramáticos, se troca por uma rota sensorial, uma soma-seqüência de eventos com fracas ligações causais. As relações entre os personagens são sustentadas por informações esparsas e ambíguas. As elipses abundam e criam buracos no filme, passagens inconclusas, escavações profundas, ausências insondáveis. Abdica-se do caminho que vai das aparências aleatórias do mundo sensível rumo à obra enformada segundo o que Mourlet denominava uma "seleção das aparências". Montar não é mais lapidar o material bruto em direção a uma forma significante, mas gerar um continuum pela soma das intensidades individuais de cada plano. O conteúdo do filme é reduzido a dados sensoriais imediatos. Denis e Grandrieux querem expressar mais imediatamente sensações, fugir da narratividade para dar ênfase ao físico, livrar o filme do "tema" para dar plenos poderes à sua “força afetiva". Para tanto, é necessário libertar as imagens da lógica, adotando uma espécie de visão plástica, um olhar que só capta do mundo as formas primárias, formas "instintivas", que contêm poucos significados e muitas qualidades sensórias. O meio essencialmente psicológico do cinema narrativo é trocado por uma zona sub- ou quiçá supralógica. A narrativa já não reside nas relações das imagens entre elas enquanto significados. $\mathrm{O}$ filme até oferece possibilidades de significação e permite interpretações nuançadas de seu

193 Ibidem, p. 77. 
conteúdo, mas sua eficácia maior consiste em agitar a consciência do espectador com infinitas hipóteses não conclusivas.

O drama está diluído nos elementos de base do filme, não há como decantá-lo da duração, do sentimento do espaço, da intensidade da luz, das "sobras de matéria". A unidade estrutural da obra não está na cadeia de fatos bem alinhavada, no equilíbrio cênico (das cenas em si e das cenas entre si), na correspondência dos efeitos às causas, na lógica dramática do enredo, mas antes na amarração plástico-conceitual, na coerência entre um conceito e as formas plásticas que o veiculam. O lugar antes ocupado pela dramaturgia ou pela narratividade é agora preenchido por um arcabouço conceitual. Justamente porque há essa aparelhagem teórica precisamente plantada na base do filme, Claire Denis e Philippe Grandrieux podem se livrar, no momento de ligar a câmera, a uma filmagem pulsional, instintiva, "um traçado, uma concepção da mise en scène como sismografia" (Lalanne). Eles podem encarar cada plano como uma simples captação de intensidades. Os estilos de narração e dramatização, de decupar na matéria do real uma história fictícia, se tornam mais volúveis e imprevisíveis. A decupagem já não é funcional, o drama já não depende da sucessão dos planos. A mise en scène, nesse caso, é menos uma colocação em cena propriamente dita do que um conjunto de operações estéticas armado em torno de um repertório de conceitos. A mise en scène se troca por um "trabalho de imagens" (Aumont), abandonando suas raízes teatrais e renunciando a ser aquela arregimentação de técnicas e elãs que, em outras épocas, havia permitido aos diretores de cinema encontrar "uma forma original de representar o homem (e, acessoriamente, o mundo)" a partir de exigências de ordem cênica e dramatúrgica. Encontrar essa "fala do mundo", para Grandrieux e Denis, implica desfazer os contornos da cena, buscar o que está além dela, o que se agita no fundo desdiferenciado do qual emergem e se destacam todos os objetos que se apresentam à nossa consciência. 


\section{O olhar, o quadro, a cena}

Um olhar se detém sobre um determinado aspecto do mundo. Esse olhar obtém um quadro. A partir desse quadro, ou de uma sucessão de quadros, organiza-se uma cena. Toda mise en scène inclui essas três etapas fundamentais. O que diferencia uma mise en scène da outra, e caracteriza os estilos individuais dos cineastas, são os sentimentos e as convicções diversas que eles empregam em cada uma dessas atividades. "Numa encenação, há sempre uma parte de coreografia, ou seja, de domínio total dos movimentos num espaço definido", diz Jacques Aumont. Mas há também, ele mesmo completa, “a parte de 'mistério' de que fala Éric Rohmer, que é muito simplesmente a marca pessoal do cineasta, o jogo do seu olhar sem regras a priori a não ser a da expressão, do charme, da elegância, da medida, em suma, sem outra regra que não a da arte" 194 .

O cinema é uma interpelação de aparências fugidias. Diante disso, uns sentem necessidade de fixar um centro, um núcleo de imantação das evidências alcançado por um máximo de concentração e foco. Outros preferem que seus filmes revelem menos uma vontade de ordenação e sabedoria do que uma arte fundada no instante, descoberta no ato mesmo de sua criação. Foi assim desde sempre.

Num pequeno texto intitulado "Le plan"195, Aumont identifica nos primórdios da atividade cinematográfica a formação de duas modalidades de plano - o termo "plano" aqui sendo tomado como unidade fundamental, o "elemento celular de base do edifício fílmico" (Bonitzer).

A primeira modalidade, Aumont denomina plano-tableau, não no sentido de um tableau de pintura, de efeitos de enquadramento ou de composição, e sim no sentido do tableau numa peça de teatro ou numa apresentação de music-hall. Nesse plano-tableau está a origem espetacular do cinema. Ele funciona como a versão impressa de um palco, de um cubo cênico: espaço fechado + duração + ponto de vista frontal e fixo. O plano-tableau aparece no Black Maria de Edison e prossegue tanto nos filmes de Griffith para a Biograph quanto nas fitas anônimas do vaudeville primitivo, do cinema burguês dos primórdios, do drama dos primórdios. O plano nesse caso é uma unidade de ação e dramaturgia.

A outra modalidade de plano nasce com Lumière, cujas "vistas" encarnam uma outra atitude e disposição: não mais um tableau, mas sim um plano-olhar, ou seja, uma operação que corresponde à equivalência entre um plano de cinema e "um certo olhar lançado sobre um

\footnotetext{
194 O cinema e a encenação, p. 52.

195 Cf. Cahiers du Cinéma, número especial "Le siècle du cinéma", novembro de 2000.
} 
certo momento de um certo pedaço do mundo". O plano se torna tão-somente o olhar, a atenção visual, a concentração, a focalização - uma consciência lançada no mundo.

E os rumos do plano-olhar não seriam unívocos. Em alguns momentos, ele se apresentaria como uma ferramenta maravilhosamente adaptada "a fornecer a fluidez, a labilidade, as cores flutuantes e os humores que realçam nossa presença fenomenológica no mundo". A vista Lumière continha uma idéia de registro que extrapolava a cena e a ação dramática: havia a cintilação do real no fundo do quadro (vale lembrar que as folhas das árvores atrás da cena do bebê sendo alimentado foram o que chamou a atenção de Méliès em Le Déjeuner de Bébé).

Em outros momentos, Aumont afirma que o plano-olhar, inversamente, buscaria "a acuidade máxima, a capacidade cortante de enquadrar e de centrar, de desenhar por uma exacerbação ou uma exorbitância simbólicas um fragmento de mundo subitamente inchado por uma atenção humana".

Há, portanto, duas escolas do plano-olhar: uma que queria, antes de mais nada, deixar o olhar flutuar e errar sem se manifestar por si mesmo, que Aumont chamará de escola Rossellini, e outra que queria, ao contrário, que a cada instante o olhar marcasse sua presença, sua existência e seu poder, a escola Hitchcock.

Mais adiante, Aumont conclui que, num caso ou no outro, as distintas definições de plano não escondem o que partilham de essencial: todo plano é uma intensidade. "Intensidade de movimento, intensidade de tempo, intensidade de cor e de luz...”.

No plano-olhar lumièriano, assim sendo, está o embrião de duas escolas bastante distintas, duas vertentes que não cessariam de se opor ao longo da história do cinema: de um lado, o plano como um exercício do olhar, uma ferramenta da percepção sensível, o registro "solto" de uma determinada experiência do homem em sua relação com o mundo; do outro lado, o plano como material de condução de uma vontade do espírito, veículo privilegiado para a expressão de um pensamento. Em ambos, uma idéia de plano como um agenciamento de intensidades.

Curiosamente, Godard já havia feito uma bipartição semelhante à de Aumont no último segmento de sua ode a Ingmar Bergman ${ }^{196}$ :

Em linhas gerais, há dois tipos de cineastas. Os que caminham pela calçada olhando para o chão e os que o fazem com a cabeça erguida. Os primeiros, para ver o que ocorre ao seu redor, estão obrigados a levantar a cabeça com freqüência e repentinamente, e a girá-la tanto à direita como à esquerda, abarcando com várias vistas o campo que

196 “Bergmanorama”, Cahiers du Cinéma nº 85, julho de 1958. 
se oferece ante os olhos. Estes primeiros vêem. Os segundos não vêem nada, miram, fixando sua atenção num ponto preciso que lhes interessa. Quando se dispõem a rodar um filme, o enquadramento dos primeiros é aéreo, fluido (Rossellini); o dos segundos está calculado ao milímetro (Hitchcock). Encontrar-se-á nos primeiros uma dissociação das cenas sem dúvida disparatada, mas tremendamente sensível às tentações do acaso (Welles); e nos segundos, uns movimentos de câmera não apenas de uma precisão inaudita no set, como também com seu próprio valor abstrato de movimento no espaço (Lang). (GODARD, 1958)

O primeiro grupo é denominado por Godard o do "cinema livre" (ao qual pertencem Rossellini, Welles e Bergman ${ }^{197}$ ); o segundo é o do "cinema rigoroso" (o de Hitchcock, Lang e Visconti). Se os cineastas "livres" reivindicam uma importante margem de manobra no momento da filmagem, os "rigorosos" estão extremamente preocupados em prever cada detalhe de cada plano.

Tanto Godard quanto Aumont falam de dois comportamentos básicos do olhar, que se traduzem em duas formas diferentes de enquadrar, de estabelecer limites, de figurar corpos em espaços delimitados por um quadro. "O modo como se enquadra um plano, uma cena, não está ele ligado a estruturas pessoais, a modos de ver tanto quanto ao que se vê?"198. O quadro se define pela janela e pelos limites, pelo que contém e pelo que exclui; ele pode abrir ou fechar a obra, "pode obrigar o olhar a percorrê-la ou incitar o espírito a vagabundear para além de seus limites".

\begin{abstract}
Liberdade/encarceramento, fora/dentro, continente/conteúdo, vazio/pleno, finito/infinito. Em todas as épocas, filósofos e artistas, no Ocidente e, diferentemente, no Oriente, meditaram sobre a noção de limite, operaram a partir das noções de quadro e de fora-dequadro. A questão do enquadramento no cinema renova a dos limites, que os filósofos se colocaram, oscilando entre duas concepções, a saber, esquematicamente, a concepção platoniana segundo a qual os seres, os corpos, as coisas se definem por seus limites, e a concepção estóica segundo a qual os limites dependem do ser, os limites vão até onde pode o corpo, o ser, o personagem. (VILLAIN, 1985)
\end{abstract}

A concepção platoniana, conforme exposta por Dominique Villain, postula que uma coisa é o que é apenas no e em razão de seu limite. Já na concepção estóica a lógica se inverte: os limites é que dependem das coisas, e não o contrário. Podemos dizer que a concepção platoniana inspira os cineastas da escola Hitchcock, enquanto a noção estóica

\footnotetext{
${ }^{197}$ Logo Bergman, que mais tarde vai se provar o mais esteticamente rigoroso dos cineastas (Persona, Gritos e Sussurros, Fanny e Alexander etc).

198 Dominique Villain, L'oeil à la caméra: Le cadrage au cinéma, p. 14.
} 
serve mais à escola Rossellini.

Para Rossellini, o quadro já está nas coisas, é determinado pelo corpo do ator, pela configuração natural do espaço, pela predisposição do mundo no momento em que ele o filma. Rodar um plano nada mais é que prospectar as verdades nativas do mundo. $\mathrm{O}$ Rossellini de Alemanha Ano Zero, Stromboli, Viagem à Itália ou Europa 51 é como um escultor que faz a escultura tender a uma forma já sugerida na pedra. Sua mise en scène não obedece a regras pré-estabelecidas - se há uma lei que a conduz, é a lei intrínseca às propriedades da matéria, que só pode ser aplicada no momento do encontro, no ato do registro. A câmera é guiada pelas forças (por vezes ocultas) e potencialidades das coisas e dos seres aos quais se dirige; ela se sintoniza à respiração do mundo (e, assim, à manifestação da graça).

Em Hitchcock, por sua vez, o quadro é uma composição previamente pensada. Sua mise en scène se define pela realização de um projeto mental, pela relação entre um cálculo necessário para extrair dos meios disponíveis o máximo de efeitos - e os recursos cênicos. Os planos são gerados por um olhar inchado pela atividade cerebral, um olhar que marca o domínio e mesmo a posse do autor sobre o universo diegético. Cada gesto, cada olhar, cada pormenor do filme provém de uma mesma concepção inicial; todas as unidades de encenação devem respeitar o sentido da unidade superior a que pertencem. Respeito não mais à matéria como era em Rossellini, mas à Idéia que a enforma. Técnicas analíticas, atenção ao detalhe relevante, precisão dos contornos: é assim que Hitchcock opera. Sua transparência consiste em nos permitir enxergar, com o mínimo de empecilhos, o desenho interior do qual o filme seria a manifestação externa e visível.

Duas cenas podem ilustrar as diferenças expostas acima. A primeira é a seqüência final de Stromboli (1950), de Rossellini, em que a personagem de Ingrid Bergman está tentando chegar ao outro lado da ilha para fugir da vida frustrante que leva ao lado de seu marido, um rústico pescador italiano. Uma vez que não quer dar a volta na ilha de barco - o que seria mais fácil, porém atrairia a atenção de todos -, ela decide subir a montanha e enfrentar o vulcão. Ao fazê-lo, no entanto, depara-se com uma força muito maior do que pressupunha. No meio da subida, começa a ficar intoxicada com a densa fumaça expelida pela atividade vulcânica. Ela larga pelo caminho a mala onde carregava suas coisas, mas segue andando. Exausta, atinge uma parte alta da montanha e enxerga à sua frente a boca do vulcão em fúria. Ocorre um plano/contra-plano entre o rosto de Ingrid Bergman e o vulcão cuspindo lava. “Enough! Enough!”, ela exclama como se não suportasse mais tamanha força, tamanha intensidade. Ela protege o rosto daquela visão atordoante; seu olhar está recebendo do mundo 
uma carga brutal de energia. Os elementos vão se emaranhando ao longo da cena. Os contornos das coisas ficam nublados. A fumaça, o céu, as nuvens, as cinzas, as pedras, os pássaros, o mar lá embaixo, o vestido da atriz, tudo se homogeniza num mesmo preto-ebranco.

A título de contraposição, a segunda cena que gostaria de destacar é um dos trechos mais famosos de Os Pássaros (1963), de Hitchcock. É aquela cena em que Mitch (Rod Taylor) e Melanie (Tippi Hedren) estão na lanchonete de Bodega Bay, que fica em frente a um posto de gasolina. Eles discutem com habitantes e autoridades locais a estranha situação que se criou desde que os pássaros iniciaram os ataques inexplicáveis. O clímax da cena começa quando Hitchcock interrompe a longa tomada em que Melanie havia ficado sempre em segundo plano ouvindo a conversa de Mitch com outros personagens e corta para um plano que a coloca em evidência isolando-a do restante: é o momento em que ela ouve o som de um pássaro e um novo ataque se anuncia. Ela se dirige à janela da lanchonete, avista a chegada dos pássaros e alerta a todos: “Olhem!". Mitch e o homem com quem conversava vão para a janela; assistem aos pássaros derrubando o frentista do posto e este deixando cair a mangueira de gasolina. Mitch sai para socorrer o frentista. O combustível, enquanto isso, esguicha livremente da mangueira e se alastra pelo chão. Em montagem precisamente ritmada, vemos a gasolina se espalhando e Melanie observando a cena da janela da lanchonete, por trás do vidro, rodeada de várias outras pessoas que ali se amontoam. Ela percebe que, do outro lado do posto, um homem distraído se prepara para acender um charuto e jogar o fósforo no chão, sem notar que o espaço está encharcado de gasolina. Melanie abre o vidro e grita tentando avisá-lo. Quando olha na direção de Melanie, o homem se assusta com o fósforo que lhe queima os dedos e solta-o por reflexo: o incêndio começa, os carros ao lado explodem, o fogo se espalha. É então que se dá uma rápida sucessão de planos alternando entre o rosto de Melanie - desta vez mais destacado que nunca dos outros personagens - e o fogo se propagando num filete de combustível que corre pelo chão. Nesta breve seqüência de planos, cada tomada de Melanie mostra seu rosto paralisado em uma pose diferente. Ela vai virando o pescoço da esquerda para a direita do quadro, o percurso do seu olhar correspondendo ao trajeto do fogo que atravessa toda a extensão do posto até atingir a bomba de gasolina e provocar uma enorme explosão. Melanie, boquiaberta e com os olhos arregalados, está empalhada nesses planos; ela não se mexe, apenas olha fixamente, em pose estática. Hitchcock de certa forma abstrai o olhar de Melanie do resto de seu corpo, do resto do universo, transforma-o numa entidade autônoma. Cada close-up de Tippi Hedren funciona como a reverberação em imagem do que ela havia dito no começo da cena: “Olhem!”. Esse 
imperativo, agora, ganha seu verdadeiro sentido dentro do filme, que é menos de alerta do que de ataque. A cada olhar de Melanie, o fogo se intensifica e agudiza sua investida contra os homens ${ }^{199}$. Somente no último plano da série ela rompe sua fixidez e executa uma ação, que é justamente a de colocar as mãos no rosto em resposta instintiva ao horror. Mas há uma diferença entre esse gesto de Melanie e aquele de Ingrid Bergman em Stromboli. Lá, era o mundo que afetava o olhar da personagem com sua potência, seu fogo, e ela levava as mãos ao rosto num misto de desespero e súplica. Aqui, é o olhar da personagem que exerce seu poder e (metaforicamente) põe fogo no mundo - levar as mãos ao rosto, para Melanie, pode ser um sinal de arrependimento.

A personagem de Ingrid Bergman vê; a de Tippi Hedren mira. Há dois diferentes regimes de luminosidade em jogo: um paradigma lumen, que pressupõe uma luz já existente nas coisas e passível de ser captada pelo olho (Stromboli), e um paradigma lux, de uma luz que provém do olho e anima os objetos, sendo um "produto do espírito" o que dá a textura do mundo e de suas coisas (Os Pássaros $)^{200}$. De uma forma de olhar para a outra, a lógica muda completamente. Os contornos fluidos e anuviados de Rossellini cedem lugar a uma precisão absoluta dos traços. As cores não se aparentam mais entre si, não se misturam; uma figura não invade o espaço da figura vizinha, tudo pode ser percebido com nitidez. Enquanto Rossellini conserva na matéria sensível do filme o caos original do mundo, que somente uma ordem divina pode enformar, Hitchcock já quer ser, ele próprio, o mestre do universo, salvando a imagem da indistinção primitiva entre figura e fundo, corpo e sombra, desenho e cor.

Redundante dizer, a esta altura, que a definição desses dois tipos de olhar, o hitchcockiano e o rosselliniano, permite-nos cotejá-los com as duas categorias descritas no texto "Plan contre flux" de Stéphane Bouquet. As estéticas do plano e do fluxo apresentadas por ele seriam desdobramentos tardios das escolas Hitchcock e Rossellini, respectivamente.

O que nos interessa aqui é esse ponto-limítrofe da escola rosselliniana: um olhar que se desliga do centro do quadro, não mais se fixa ansiosamente sobre os aspectos “importantes" do mundo, pois prefere estar atento ao insignificante, perder-se no fluxo sensório-temporal da realidade fenomênica. Esse olhar gasta mais tempo que o habitual para

\footnotetext{
199 Como bem se sabe, há várias formas de interpretar a participação de Melanie na trama como a desencadeadora dos ataques. São diversas as cenas que o indicam (a começar por aquela logo no começo, em que Melanie, como a incitar uma rebelião, abre a gaiola de um passarinho e ele sai voando pelo interior de uma pet shop). Mesmo quando ela tentou salvar a vida daquele homem que acendia o charuto, sua boa intenção se converteu em destruição: talvez se ela não tivesse gritado para chamar sua atenção, ele não teria queimado o dedo com o fósforo aceso, não teria deixado o fósforo cair, e o incêndio seria evitado. Não à toa, a sequência termina com uma mulher apontando o dedo para Melanie e acusando-a de ter levado a desgraça para a pequena província de Bodega Bay.

200 Cf. Stéphane Bouquet, "Des films et des gestes", in Cahiers du Cinéma n 578, abril/2003.
} 
transitar de uma porção do espaço a outra, de um corpo a outro, como se quisesse perceber os pequenos eventos que se escondem entre as coisas. O relevo, o clima, a atmosfera das obras sobressai com mais intensidade, se torna mais concreta, ao passo que a narrativa se dissolve. O foco principal não é a existência enquanto geradora de histórias, mas a matéria sensorial do mundo. Ao explorar espacialmente o real e deixar escapar o fio linear do relato, o olhar é devolvido a um prazer primordial, uma vez que o ato de ver, em si, não organiza o espaço de maneira narrativa/descritiva: seu movimento é circular e inconcluso. A imagem perde grande parte de sua função de estruturação do espaço e da cena; ela é trabalhada em termos de ritmo e textura, mas não de quadro ou de decupagem. O plano, então, não é uma distribuição dos corpos no espaço emoldurada por uma composição pictural, mas uma captura de forças. "Os planos se rompem em mil pedaços, as fronteiras se enfraquecem, o recorte das coisas torna-se menos franco"201. O quadro - que implicaria um sentido mais analítico de composição - se troca por um campo volúvel onde o que se tem sob o olhar é sempre uma visualização parcial e uma potência indeterminada. O real toma a forma de uma universal variação; tudo é percebido mas de certa forma nada é retido. Em O Intruso, por exemplo, a matéria do mundo se acha em combustão interna, como era em Rossellini, mas o vulcão, ao contrário daquele de Stromboli, é invisível, sua lava escorre subterraneamente, sensualmente, queima sob os pés dos personagens sem que eles o saibam. Ninguém exclama mais seu mistério e sua beleza ("What mystery! What beauty!", exclamava Ingrid Bergman estupefata na cena final de Stromboli). A matéria reflui sobre si mesma em silêncio. O drama se contrai numa tênue superfície que recobre a terra e que, privada de sua espessura, agita-se a fim de expandir-se, movimentar-se: o resultado é uma vibração na epiderme do mundo. Há uma atividade intensa do quadro, uma "inflamação das suas bordas" (Aumont), uma dissolução dos moldes pictóricos, exacerbando uma característica que, segundo Bazin, seria já intrínseca à natureza do enquadramento no cinema.

Debruçando-se sobre a comparação cinema/pintura, Bazin fez a célebre formulação: "O quadro é centrípeto, a tela é centrífuga" ${ }^{202}$. A tela, ou o quadro fílmico, leva o olhar para longe do centro, para além de suas bordas, pedindo, inelutavelmente, o fora-de-campo. O quadro pictórico, ao contrário, é "centrípeto": ele fecha a tela pintada sobre o espaço de sua própria matéria e de sua própria composição, obriga o olhar do espectador a voltar sem parar para o interior, a ver menos uma cena ficcional do que uma pintura, um pensamento posto em obra através de cores e formas. O quadro da pintura constitui uma zona de desorientação do

201 Ver Emmanuel Burdeau, em FRODON, Jean-Michel (dir.), Hou Hsiao-hsien, Paris: Éditions Cahiers du Cinéma, 1999, p. 169.

202 BAZIN, André, "Peinture et cinéma", in Qu'est-ce que le cinéma?, Paris: Les Éditions du Cerf, 1985, p. 188. 
espaço: “Àquele da nossa natureza e de nossa experiência ativa que bordeia seus limites exteriores, ele opõe o espaço orientado de dentro, o espaço contemplativo somente aberto sobre o interior da pintura" (Bazin). Já a tela de cinema não é um quadro como o da pintura, mas um cache que só permite perceber uma parte do evento, que só desvela uma parte da realidade representada, realidade que existe para além do enquadramento que dela é feito. Contrariamente ao quadro da pintura, que polariza o espaço para dentro de si, e o alija da realidade que ele representa, a função do quadro cinematográfico "é menos a de furtar a realidade ao olhar que a de revelá-la; o que ele mostra tira seu preço do que ele esconde, o testemunho invisível do filme possui antolhos, sua ubiqüidade ideal é temperada pelo enquadramento" 203 .

Nos filmes de Claire Denis, Philippe Grandrieux e Hou Hsiao-hsien, essa noção de que um plano de cinema é antes um cache do que um quadro é mobilizada a todo momento. Eles mantêm uma relação provisória com o enquadramento, este sendo menos um recorte preciso do que uma sensação momentânea do espaço. Comentando o processo de composição de alguns planos de Sombra, Grandrieux confessa uma prática interessante: "Há momentos em que fecho os olhos enquanto enquadro. Pode-se pensar que ao fechar os olhos enquadramos mal; na verdade, enquadramos exatamente como deveríamos, pois entramos numa relação íntima com o mundo que está ao nosso redor, como os cegos devem estar com o universo. Eles têm uma percepção do mundo bastante fina, sensorial. Se por alguns momentos fechamos os olhos e continuamos o movimento, este adquire uma força incrível, porque não está ligado ao visível, e é transmitido de maneira bastante erótica" ${ }^{204}$. Nesses momentos em que fecha os olhos, Grandrieux enquadra tateando no escuro, intuindo os deslocamentos dos atores no espaço, farejando os humores, sentindo a respiração.

Em Nénette et Boni (1996), de Claire Denis, o quadro também é um “campo erótico". O filme se constrói num elã sensual que começa pela forma de enquadrar e decupar as cenas. A câmera - freqüentemente em primeiríssimo plano - passeia lentamente pelos corpos, deslizando sobre a pele dos atores, apalpando-os, perfazendo as silhuetas, gerando uma confusão entre o óptico e o háptico. Os enquadramentos (sempre fragmentários) e os

\footnotetext{
${ }^{203}$ Villain, op. cit., p. 122. Ele nos alerta ainda de que mesmo na pintura as noções de quadro e de centro já são problematizadas, e não necessariamente a partir da invenção do cinema: "A pintura se transformou e uma das grandes rupturas da pintura moderna com a antiga é, precisamente, uma liberação em relação à forma do quadro que o cavalete implicava. Os pintores inventaram várias formas de romper com as delimitações do quadro tradicional, enquadramento e bordas do tableau, e com a ordenação interna que regrava a composição, simetricamente e em profundidade, em relação a um centro. A Action Painting, a pintura ao solo, all-over, de Jackson Pollock, é uma das mais significativas a esse respeito. Mas Van Gogh já se questionava como posicionar seu cavalete para pintar um sol poente" (p. 123).

204 Grandrieux, "Baignade interdite", Cahiers n' 532, fevereiro de 1999, p. 42.
} 
movimentos tornam provisórios os limites entre os corpos; as formas e os contornos se interpenetram, se misturam como nas pinturas de Rubens. Tudo passa uma impressão de vida e vigor: as coisas respiram e palpitam na superfície do plano onde os corpos se atraem e se magnetizam.

Os dois personagens do título são um casal de irmãos. Nénette (Alice Houry) tem quinze anos e descobre que está grávida. Ela não quer o bebê, mas já é tarde demais para abortar. Boni (Grégoire Colin), seu irmão, possui uma van onde faz e vende pizzas. Ele tem constantes fantasias sexuais com a mulher do padeiro da vizinhança, interpretada por Valéria Bruni-Tedeschi. O filme cria entre os dois uma relação à distância, por meio de um paralelismo de suas atividades. As mãos de Boni preparando a massa da pizza, os formatos dos pães vendidos por ela, o creme dos doces na vitrine da padaria, tudo isso é erotizado pela câmera de Agnès Godard (diretora de fotografia e operadora, braço direito de Claire Denis). Na cena em que Boni e Nénette aparecem juntos pela primeira vez, ele está tendo mais um de seus sonhos eróticos, até que acorda assustado, percebendo que acariciava o corpo de sua irmã enquanto sonhava. A penumbra do quarto corrobora a confusão. Mas tão-logo se dá conta do engano, ele a repele ${ }^{205}$.

Nénette havia surgido inesperadamente no meio da noite, depois de muito tempo sem ver Boni, quase como se fosse uma aparição fantasmática. Em vários momentos, o filme mistura sonho e realidade sem que se possa diferenciá-los. Um exemplo é a cena em que Boni e a mulher do padeiro se encontram num shopping. Ela está numa loja de perfumes, experimentando algumas amostras que a vendedora lhe oferece. Depois que ela sai de quadro pela direita, corta para um contra-plano de Boni a observando através da vitrine. Ela ressurge pela esquerda, abordando Boni e convidando-o para um café, como se saísse do espaço da realidade e, num movimento contínuo, dentro do eixo, adentrasse o espaço da imaginação íntima do rapaz. Não há nenhuma chave de interpretação dessa seqüência como mais um sonho de Boni ou como um encontro que ocorre de fato. Claire Denis trata o real e o onírico com imagens de mesmo teor ontológico; a realidade e suas projeções imaginárias se fundem numa só substância.

Sentados em algum café do shopping, Boni e a personagem de Valéria Bruni-Tedeschi conversam. Na verdade, ela fala e ele simplesmente ouve. Ela estende o pulso a Boni e pede que ele sinta o cheiro do perfume. Ela diz que se interessou por perfumes depois que leu um artigo sobre ferormônios, substâncias químicas que são transmitidas de um corpo a outro

${ }^{205}$ Claire Denis: "Há alguma coisa aí que não tem a ver com o incesto (isso seria muito simplificador), mas com dois corpos que se atraem, talvez porque eles têm o mesmo odor, e ao mesmo tempo eles se defendem disso e preferem tudo destruir a aceitar essa atração" (Cahiers du Cinéma n $\mathrm{n}^{\circ}$ 501, p. 58). 
enviando sinais de compatibilidade sexual. "Entre o homem e a mulher, a coisa é química", ela afirma e acrescenta: "são fluidos invisíveis que estão em todo lugar: nas ostras, na cerveja, nas flores...”. A cena é filmada com pouquíssima profundidade de campo: atrás dos rostos, a imagem está totalmente desfocada, vários pontos de luz reduzidos a pequenas manchas coloridas, um espaço confuso, indefinível, fazendo eco a esse mundo das sensações e dos desejos. Os ferormônios pertencem àquelas coisas que os homens possuem em comum com os outros animais, e que Claire Denis adora pôr em evidência. Concreta e evanescente ao mesmo tempo, essa cena no shopping versa sobre a bipolaridade fundamental do cinema de Claire Denis: ela filma corpos indecisos entre uma realidade carnal e um estado vaporoso; seu olhar está mergulhado nas contexturas da pele, da carne, mas interessado também nas vibrações invisíveis, nas emissões feromônicas, nas fragrâncias afrodisíacas exaladas pelos corpos.

Nénette et Boni foi o filme em que Denis tornou sua câmera ainda mais fluida e corpórea que antes. Um filme de primeiros planos, bem à flor da pele. O plano de abertura, que constitui uma seqüência autônoma e permanecerá narrativamente desvinculado do resto do filme, mostra um homem vendendo documentos falsos e dando instruções de como usá-los a um grupo de imigrantes africanos. A cena pareceria uma sobra de Noites Sem Dormir, não fosse pelos movimentos de câmera que já apresentam essa nova maneira de filmar que Nénette et Boni inaugura na obra da diretora: a câmera flutua de um rosto a outro, anunciando esse mundo onde tudo desliza de um ponto a outro do espaço a todo momento.

Ainda no começo, há uma cena em que Boni está em seu apartamento e anda para lá e para cá, lendo uma redação que ele escreveu em primeira pessoa, na qual confessa sua atração pela mulher da padaria. $\mathrm{O}$ enquadramento é restrito, fechado sobre o ator, obrigando a câmera a se mover constantemente para acompanhar suas oscilações. Em determinado momento, Boni ouve algum barulho e sai de quadro correndo. Ele volta logo depois com uma espingarda e se dirige à janela, disparando alguns tiros de chumbinho para espantar os gatos da vizinhança. Ao final do plano, Grégoire Colin está a poucos centímetros da câmera. Desse jogo instável entre a câmera e o ator, uma coreografia acaba sendo construída. O plano se mede e se molda pelo sentimento de presença e de movimento do personagem. O quadro negocia seus limites com os deslocamentos do ator, com o volume do espaço, com a dinâmica ou a inércia da cena. Cada cenário e cada ator possuem um ritmo e uma respiração que lhes são próprios, e cujos traços Denis quer guardar. Enquadrar, aqui, implica uma relação privilegiada com o ator, com seu gestual. "Para adivinhar o que as pessoas (os atores) vão 
fazer, é preciso estar completamente com eles, são relações no espaço" ${ }^{206}$. A câmera, também ela, é posta em cena como um ator, como um corpo. É isso que vai determinar o quadro: a relação desse corpo-câmera com os demais corpos. Denis está atenta aos estremecimentos do real, às sensações provocadas por ele. Cineasta do corpo mais que da palavra ou do discurso, ela se mostra sensível aos pequenos acidentes que acometem os atores. "Suas indicações aos atores, durante os ensaios ou entre duas tomadas, dizem respeito muito mais aos estados do corpo que ao texto em si. [...] Daí ela se concentrar intensamente nos menores gestos (uma tensão da mão, um abandono do pé, um jogo imperceptível do olhar), ainda mais quando enquadra de modo fechado" 207 . Os atores devem "se fabricar uma memória corporal da duração do plano", devem trazer na pele o ritmo da cena. Primazia da energia dos atores sobre a lógica das coisas, da matéria sobre o quadro.

Uma igual atenção às nuances de expressão dos atores e às microcirculações que preenchem o campo (visual e sonoro) pode ser vista em uma cena de $A$ Viagem do Balão Vermelho (Hou Hsiao-hsien, 2007). Trata-se do plano-seqüência em que o afinador de pianos vai ao apartamento de Suzanne (Juliette Binoche), locação onde ocorrem as cenas mais complexas do filme, quase todas filmadas com a câmera num lugar de onde é possível enquadrar simultaneamente a porta de entrada do apartamento, a mesa da sala e uma parte da cozinha, bastando ainda uma simples panorâmica para que se passe ao outro lado do cenário (a continuação da sala, a escada para o mezanino, a porta do quarto). O diretor, assim, pode fazer um uso impressionante da soma de eventos em um mesmo plano. O apartamento exíguo e amontoado se abre como um espaço cênico de infinitas possibilidades. No plano-seqüência em questão, a câmera começa em Simon ${ }^{208}$ jogando videogame. Os sons do jogo eletrônico predominam na pista sonora, até que ouvimos o barulho da porta da sala se abrindo e a câmera, como que curiosa em relação a quem acaba de chegar, desliza suavemente naquela direção, por onde entram Song ${ }^{209}$ e o afinador de pianos. Este é conduzido por Song ao canto da sala em que fica o piano, onde ele se instala e começa seu trabalho. A câmera, nesse primeiro momento, já saiu de um plano médio (Simon jogando videogame), passou por um plano geral (Song e o afinador entrando no apartamento) e agora está num plano aproximado das teclas do piano. Marc ${ }^{210}$ abre a porta, pergunta por Suzanne, Song diz que ela não está e

\footnotetext{
206 Villain, op. cit., p. 80.

${ }^{207}$ Stéphane Bouquet, "Claire Denis, les années sauvages de Nénette et Boni”, em Cahiers du Cinéma n n 501, p. 58.

${ }^{208}$ O filme foi livremente adaptado de O Balão Vermelho (1956), de Albert Lamorisse. Simon é o menininho que fica sendo perseguido amigavelmente pelo balão.

209 Song é uma jovem chinesa que estuda cinema em Paris e é a nova babá de Simon.

${ }^{210}$ Marc é o vizinho/inquilino do apartamento de baixo, que deve vários meses de aluguel e ainda pede favores inconvenientes a Suzanne.
} 
ele fecha a porta nitidamente irritado. O afinador continua seu trabalho e a câmera nele permanece mesmo quando o telefone toca. Song atende em off: é Louise, irmã mais velha de Simon. Uma suave panorâmica à esquerda nos leva de volta a Simon, que agora fala ao telefone com Louise. Simon está sentado no chão, e ao redor dele se encontram fitas VHS empilhadas, estantes repletas de livros, revistas espalhadas pelo assoalho, cartuchos de Playstation, uma caixa de som, muitos fios. Em off, começamos a ouvir uma discussão de Suzanne com Marc. Suas vozes vão subindo de volume. A câmera faz uma lenta panorâmica em diagonal ascendente para a direita, e termina enquadrando a porta, a mesa, Song na cozinha, um pedaço do ombro do afinador de pianos. Suzanne abre a porta e sua discussão com Marc invade a cena de vez. Eles esbravejam agressivamente. O som sobrepõe os registros: briga de Suzanne com Marc, Simon falando ao telefone, notas saídas das teclas do piano, ruídos de ambiente. Marc vai embora e Suzanne bate a porta com força. Essa exaltação de ânimos que leva à conflagração de um conflito no interior do plano-seqüência lembra os momentos de bagarre do cinema de Maurice Pialat (Loulou, Aos Nossos Amores, Passe ton bac d'abord), um tipo de explosão repentina dos personagens e da energia do plano que Hou já apresentava também em Adeus ao Sul, Flores de Xangai e Millennium Mambo. Depois que a discussão termina, Simon passa o telefone para Suzanne, que, enquanto fala com Louise, vai até o quarto, saindo de quadro por uns segundos, para depois retornar e se dirigir à cozinha. A câmera a acompanha e em seguida se concentra no trabalho manual do afinador por um breve momento; reencontra Suzanne se servindo um copo d'água e voltando para o fundo da sala. Suzanne senta perto de onde Simon estava no começo da cena, enfocada sozinha em plano médio. Desliga o telefone. Simon logo entra em quadro e eles conversam. Ela pergunta como foi seu dia, o que aprendeu na escola etc. Simon depois se afasta e Suzanne fica sozinha no quadro novamente, com o rosto cansado e um pouco distante, criando um desses momentos abismantes do cinema de Hou em que, no meio de um cenário povoado de gente e de acontecimentos, um personagem de repente se destaca e passa a habitar uma zona de solidão, é sugado por uma bolha de tristeza. Suzanne quebra o próprio silêncio e faz perguntas quaisquer a Song e ao afinador. Suzanne levanta e se encaminha à mesa, e a câmera aproveita para, após acompanhá-la, enquadrar o piano uma última vez, antes do corte que põe fim à cena.

O trabalho de som nessa cena é um dos principais responsáveis pela riqueza do conjunto. O afinador de pianos é um rapaz cego, e talvez Hou Hsiao-hsien tenha situado nele o ponto de escuta, com tudo que isso implica de uma sensibilidade auditiva "fora do comum". O espaço se vê inundado pelo "pequeno mundo dos agudos", uma "micro-réplica do rumor do 
mundo, que situa o filme no extremo-presente do indicativo, declina-o no extremoconcreto"211. A construção de uma paisagem sonora rica em detalhe e multiplicidade, com todas suas "capas finas de ambientes" por baixo das vozes, faz com que se experiencie mais intensamente aquela fatia de espaço-tempo proposta pelo filme. Conforme se constata na descrição da seqüência, a câmera freqüentemente se vê atraída por indicações sonoras, vai aonde o som a conduz, reage aos chamarizes auditivos do ambiente (por exemplo: nas vezes em que o movimento de câmera é precedido e estimulado pelo som da porta se abrindo). A um espaço recheado de micro-eventos sonoros, corresponde um campo visual transbordante, elástico, que busca de alguma maneira desdobrar o aspecto não-hierarquizado do campo acústico.

Ao longo de todo esse plano-seqüência de $A$ Viagem do Balão Vermelho, a câmera se movimenta, explora o espaço, realiza reenquadramentos constantes, não sabe em que se fixar, passa de um centro de gravidade a outro, escamoteia um detalhe para melhor fazê-lo ressair. O olhar desliza de uma a outra parte do cenário, destaca nuances, capta minuciosamente todos os deslocamentos de massas, as circulações de energia, as oscilações atmosféricas; um olhar sensível às menores manifestações epifenomenais que circulam no campo, capaz de "registrar com toda precisão as ínfimas variações das coisas, as que surgem bem como as que retornam ao grande fundo indiferenciado" ${ }^{212}$. A flutuação do quadro decorre da necessidade de, face às reconfigurações da cena, encontrar sempre o ponto de vista que preserve o tempo justo de cada ação, de cada entonação: não se enquadra apenas no espaço, mas também no tempo. $\mathrm{O}$ próprio ato de enquadrar, para Hou Hsiao-hsien, consiste menos em delimitar um retângulo de imagem do que em criar uma disponibilidade àquilo que se passa ao redor do quadro. $\mathrm{O}$ forade-campo é uma energia potencial que a câmera está sempre pronta a ativar. "Esse olhar, plano-quadro, onde as coisas podem (ou não) surgir, é sobretudo uma maneira de experimentar uma distância e um tempo [...] tal uma faculdade hipnótica, ou uma força de impregnação, a tela se torna uma porta entreaberta sobre o tempo e o espaço do plano"213.

Uma comparação pode nos ser útil: em The Criminal (1960), de Joseph Losey, há um plano simultaneamente similar e oposto a esse plano de $A$ Viagem do Balão Vermelho que acabamos de analisar: um plano bastante longo rodado na sala de um apartamento, com um homem tentando afinar um piano em meio a uma série de outros eventos concomitantes. $\mathrm{E}$ as coincidências não param por aí: a câmera também ocupa um lugar estratégico onde pode abarcar diferentes partes do cenário e movimentar-se constantemente. O plano começa

211 Michel Chion, "Revolución suave... y duro estancamiento", em Teoría y crítica del cine, p. 134.

${ }^{212}$ Emmanuel Burdeau, "L'écrit les cris", Cahiers du Cinéma no 606, novembro/2005, p. 26.

213 Antoine de Baecque, "Mister Hou et l'expérience du regard", Cahiers du Cinéma n ${ }^{\circ}$ 512, p. 32. 
quando John Bannion (Stanley Baker) entra na sala trazendo sua namorada no colo. Ela acaba de sair da banheira e está enrolada apenas numa toalha. Eles entram em quadro pela direita, por uma porta que fica localizada logo atrás do piano, no qual o afinador já está trabalhando. A campainha toca, a namorada de Bannion diz brincando que deve ser seu pai. Eles riem e passam por trás do piano em direção ao quarto, que vemos parcialmente através de uma porta aberta situada no lado esquerdo do cenário, para onde a câmera os acompanha com uma ágil panorâmica. Bannion joga sua namorada num sofá na entrada do quarto e vai atender a campainha. Ela levanta e vai atrás dele. Um travelling para trás combinado a uma panorâmica à direita mostra o trajeto deles até a porta, passando novamente pelo afinador de pianos, que continua fazendo seu trabalho tão alheio à algazarra quanto consegue. Bannion afasta a namorada, que volta para o quarto. Ele vai até a porta e abre. A profundidade de campo, neste momento, atinge sua amplitude máxima dentro do plano: temos o afinador sentado ao piano, a meia-distância da câmera, e a porta lá ao fundo, por onde entra em cena Michael Carter, um parceiro de Bannion. Eles vêm para o meio da sala, ao lado do piano. O quadro consiste então em: Bannion à esquerda, próximo à porta do quarto; o afinador na extremidade direita do enquadramento; e Carter em primeiro plano, no meio. A namorada de Bannion chama por ele lá de dentro do quarto, cuja porta agora se encontra fechada. Carter sai de quadro pela direita. Bannion se aproxima do afinador de piano e pergunta se ainda falta muito para ele terminar. Em seguida, vai para o quarto. Carter volta do extra-campo com uma bebida e senta no sofá da sala. O afinador pressiona três vezes uma mesma tecla bem aguda; Carter dá três batidinhas no copo com sua cigarreira, tentando imitar o timbre da nota do piano. A brincadeira se repete e o afinador protesta: "O senhor não está me ajudando". O relógio na mesinha ao lado do sofá começa a tocar, também ele num timbre parecido com o da tecla que o afinador tenta ajustar. Carter não perde a piada: "Não é seu dia de sorte, hein!". Bannion retorna do quarto. A câmera faz um travelling para frente e para a esquerda, reenquadrando Bannion e Carter em plano-médio, enquanto a namorada ressurge ao fundo, saindo do quarto já vestida. Bannion a apresenta a Carter, e em seguida ele e o parceiro se retiram da sala e vão para o quarto, para discutir seus negócios em particular.

Esse plano dura bem menos que o de $A$ Viagem do Balão Vermelho (dois minutos e meio, ao passo que lá eram cerca de oito minutos). Mas, no que diz respeito à dinâmica de entrada-saída de quadro, as duas cenas se parecem, a quantidade de ações e de movimentos de câmera sendo relativamente a mesma. O ritmo de mise en scène é sem dúvida mais ágil e conciso em Losey: cada fase do enquadramento tem uma distância focal exata, cada ator uma posição e uma disposição precisas, cada movimento de câmera um objetivo rapidamente 
atingido, enquanto em Hou Hsiao-hsien a câmera vai lentamente de um lugar a outro, estudando o espaço, modulando o foco, preenchendo a duração, como se somente no ato de se mover ela pudesse descobrir a motivação de seu movimento. O espaço cênico também difere substancialmente de um filme para o outro: em A Viagem do Balão Vermelho, o apartamento é pequeno e enfurnado, a figura humana está em igualdade com o resto, misturada à vegetação do cenário, e a câmera está espremida num canto, ao lado do piano, seus movimentos consistindo em panorâmicas e tilts em todas as direções possíveis; em The Criminal, o cenário é bem mais aberto, há mais espaço para a câmera se movimentar, cabem travellings, e o homem não se confunde à cenografia, desfruta um inegável privilégio figurativo em relação ao "pano de fundo". Os movimentos de câmera são mais leves e fluidos (porém não menos coreografados) em Hou Hsiao-hsien, e mais visivelmente marcados (porém não menos “naturais") em Losey. O campo de ação da câmera de Hou é de certo modo “circular", ela está solta em todos os eixos: vertical, horizontal, diagonal. Na cena de The Criminal, a câmera se move majoritariamente sobre o eixo horizontal, tendo alguma liberdade para reenquadramentos na vertical e pouca ou nenhuma possibilidade de movimento na diagonal. A iluminação é mais clara e homogênea em Losey: todo o cenário está exposto à mesma intensidade de luz. Em Hou, ela é mais nuançada: o cenário como um todo se acha um pouco mais escuro e cada área recebe diferentes quantidades e qualidades de luz. Nos dois casos, o campo visual é mutante, varia sua escala diversas vezes, vai do plano geral ao plano médio ou, no caso de Hou, ao primeiro plano. Mas se Losey nunca perde seu centro inabalável ("sempre permanecer ligado ao centro", dizia Mourlet), Hou desfaz e refaz constantemente o centro do plano, ou melhor, torna relativa a necessidade de definir um centro.

O espaço cênico do filme de Losey tem origem no cubo cenográfico teatral, com os corpos se dispondo segundo as leis lineares da perspectiva e organizados em torno de um centro. A expansão-contração do plano se dá mais no sentido superfície-fundo. Quanto aos atores, eles desbravam e orientam o espaço por seus gestos e seus deslocamentos.

Já em A Viagem do Balão Vermelho, as relações de profundidade não são tão bem definidas: os corpos estão mergulhados e comprimidos no plano, e este perde a característica sólida que tinha em Losey para se desmanchar numa "solução aqua-luminosa hiperreativa" 214 . O quadro é uma conseqüência imediata do aspecto fluido e dinâmico da matéria com que ele é fabricado. Os atores se deslocam em movimentos ondulatórios, indeterminados, e não em trajetórias retilíneas e demarcadas como são as de Stanley Baker em The Criminal.

$\overline{214}$ Ver Emmanuel Burdeau a propósito de Adeus ao Sul, em FRODON, Jean-Michel (dir.), Hou Hsiao-hsien, Paris: Éditions Cahiers du Cinéma, 1999, p. 170. 
A câmera de Hou está completamente imersa no ambiente, sem separação "ideal”, sem "boa distância"; seus movimentos criam uma solução de contigüidade entre todos os eventos, todas as partes do cenário, todas as ações. Há, no plano-seqüência de $A$ Viagem do Balão Vermelho, "uma espécie de indistinção do fundo e das figuras que faz com que não se esteja nunca na cenografia teatral das trajetórias e das variações de intervalos mensuráveis: os corpos estão em suspensão na solução que constitui o próprio meio [milieu] do plano"215.

Se frontalidade e centralidade são as duas palavras que melhor resumem o plano do afinador de pianos em The Criminal, o plano-seqüência de A Viagem do Balão Vermelho já sugere termos como aproximação indireta e descentramento ${ }^{216}$. Na estratégia de Hou Hsiaohsien, a batalha não necessariamente se desenrola nesse "teatro principal" que o centro do quadro tratou de representar para a mise en scène clássica teorizada pelos mac-mahonistas num sistema estético que tinha Losey como uma de suas vigas-mestras; a cena, em Hou, pode ser contornada, abordada indiretamente, pelos flancos, ou pode estar camuflada no fundo do cenário, ou ainda em permanente trânsito entre o campo e o fora-de-campo. "O plano é tomado entre dois extremos, a erupção e a extinção, mas ele oscila sobretudo em torno de uma posição intermediária, em que aparição e desaparição, presença e ausência deixam de se opor em proveito de uma qualidade geral de evanescência"217. A estratégia de Hou Hsiao-hsien (sua mise en scène?) não consiste em separar o preto do branco, mas sim em explorar todas as nuances de cor que existem entre um extremo e outro.

\footnotetext{
${ }^{215}$ Cf. Alain Bergala, "Sur un art ignoré, côté face", em AUMONT, Jacques (dir.), Le Septième Art, Paris: Éditions Léo Scheer, 2003, p. 286.

${ }^{216}$ Cf. Burdeau, "Les aléas de l'indirect", em Hou Hsiao-hsien, pp. 29-39.

${ }^{217}$ Burdeau, Hou Hsiao-hsien, p. 170.
} 


\section{Gerry}

Um carro desliza por uma estrada rodeada de vales montanhosos e desérticos. Avança num movimento plácido, sem pressa, sem destino aparente. Na trilha sonora, uma música de Arvo Pärt tão delicada quanto triste. Parece uma música de fim, e no entanto o filme acaba de começar.

Esse é o primeiro plano de Gerry (Gus Van Sant, 2002), que dura cerca de três minutos. O segundo é um plano frontal do carro, mostrando quem são as duas pessoas que o ocupam: dois rapazes, um ao volante (Casey Affleck) e outro no banco do carona (Matt Damon). O vidro está repleto de poeira, deve fazer tempo que eles viajam pelo deserto. Eles pegam uma estrada de terra, param o carro. Começam a andar a esmo. Ou melhor, têm um objetivo: querem encontrar "a coisa" ("the thing”). Que coisa? Não saberemos; será uma das muitas perguntas sem resposta do filme. Longos travellings e planos em steadycam acompanham a caminhada. Ruídos soturnos, vibrações de sons graves, alaridos de animais selvagens preenchem a pista sonora e dão às imagens uma tensão contrastante com a tranqüilidade com que os personagens exploram o espaço. Após um deles parar para urinar e comentar o quão agradável é o "ar fresco" local, eles resolvem desviar da trilha utilizada pelos turistas e fazer um caminho próprio, improvisado. "Todos os caminhos levam para o mesmo lugar”, garante Matt Damon. Eles andam, andam, andam. Depois correm, sempre seguidos pela steadycam. O som realça as passadas pesadas no solo pedregoso. Cansados de tanto correr, eles deitam para recuperar o fôlego e desistem de ver "a coisa". Decidem voltar para o carro. Ficam confusos quanto ao caminho, mas continuam andando. O dia vai terminando, vai escurecendo. Um grande plano geral não deixa dúvida: eles estão perdidos no deserto, dois pontinhos na paisagem.

A sinopse do filme poderia ficar assim: dois jovens viajam para uma região distante da civilização, pegam um desvio e se perdem. Num thriller de suspense, essa receita é fatal: uma vez perdidos e impossibilitados de voltar, os jovens se deparam com um bando de psicóticos que começa a persegui-los. Em Gerry, entretanto, os jovens se perdem no deserto e nenhum suspense decorre disso, nenhum drama. O filme se apresenta, acima de tudo, como um trabalho de ritmos, durações e atmosferas, uma jornada de fadiga dilatada ao limite. Narrativa minimal em cenário de grande aventura, Gerry faz da lentidão uma figura de estilo que permite a Gus Van Sant testar até a exaustão a hipótese de uma mineralidade do corpo e da imagem. Os planos-seqüência do filme parecem esculpidos na mesma pedra de que a maior 
parte de seus cenários naturais é feita. A montagem, por conseguinte, é uma justaposição de grandes rochas de espaço-tempo indivisíveis - uma "estética Stonehenge".

Os dois "náufragos" interpretados por Matt Damon e Casey Affleck pouco a pouco se tornam mudos e áridos como a paisagem que percorrem; eles perdem a consciência que têm do entorno, perdem a noção do espaço, para reconstruí-la então do zero (como na cena em que eles olham o mapa, Affleck tentando lembrar o caminho que fizeram). O espaço carece de referências, de marcos. É um espaço que precede qualquer tipo de organização, de orientação. Van Sant "arranca o relevo da paisagem, para devolvê-la à sua indeterminação original"218.

Borges nos ensinou que há dois tipos de labirinto. Um é formado por muros, portais, escadarias, estátuas de bronze, becos, quinas. O outro é um deserto. O primeiro tipo de labirinto, no cinema, pode ser ilustrado pelo lar aprisionante de Martha (Fassbinder), pelo edifício de Inferno (Argento), pelas mansões de A Hipótese do Quadro Roubado e Ce jour-là (Ruiz), ou ainda pela Veneza de Senso (Visconti). O segundo pode ser essa prisão a céu aberto de Gerry, esse "labirinto sem muros" onde as "situações ópticas e sonoras puras" descritas por Deleuze a propósito de Antonioni ganham um outro sentido, não mais de uma paralisação diante de um mundo do qual os personagens estão desconectados, mas de um reimplante dos corpos no tecido da realidade. O desligamento narrativo de Gerry tem como contrapartida uma redobrada vinculação dos corpos aos espaços. Van Sant filma a energia gasta nas longas caminhadas desesperançosas dos personagens, a extensão e a duração dos percursos, a ação física do sol sobre a pele. Os dias se passam e eles vão ficando cada vez mais extenuados, esgotados. Os planos acompanham esse esgotamento, como demonstrado naquela interminável tomada, já quase ao final do filme, em que os dois caminham por uma planície de sal, as pernas quase falhando, ambos na mesma passada, no mesmo ritmo, porém Damon indo bem à frente de Casey Affleck, como se o puxasse por uma corda. Eles se arrastam em suas últimas forças vitais, enquanto o dia lentamente amanhece. Dir-se-ia que eles deram a volta ao mundo.

Excursão ecológica que descamba em pesadelo, a narrativa de Gerry possui um desfecho inesperado. Depois da longa odisséia dos mortos-vivos, Affleck desaba de cansaço; Damon se aproxima e também se deita. O sol se ergue no horizonte. Exaurido, vivo somente pelo detalhe de que ainda respira, Affleck faz uma daquelas piadas que os personagens do cinema americano adoram fazer quando estão à beira da morte: "Que tal o passeio até agora?", ele pergunta a seu companheiro. Sua voz sai fraca, rouca, e após alguns segundos de silêncio ele diz: “I'm leaving...”. Ele está indo embora, deixando de vez o mundo dos vivos.

218 Delorme, “Compagnie”, Cahiers du Cinéma no 588, março de 2004, p. 43 
Casey Affleck estende o braço a Matt Damon, que primeiramente ignora o pedido de socorro, mas em seguida se projeta sobre o companheiro e começa a estrangulá-lo. Traição, maldade, loucura? Ou morte por amizade, por piedade, para encurtar a agonia e o sofrimento? Stéphane Delorme, que vê em Gerry um filme sobre a "companhia" (não sobre a camaradagem, não um buddy movie, mas um filme sobre o estar-junto), interpreta a cena da seguinte forma: "O amigo oferece a morte rápida, ele acompanha aquele que do contrário sofreria por morrer só" ${ }^{219}$. Mas há também uma outra maneira de interpretar a cena, menos "humana" e mais atida às leis gerais da biologia: o personagem de Damon simplesmente se livra de uma pele morta, abandona uma cauda que dificultava seu deslocamento. Questão de adaptação, metamorfose, seleção natural, sobrevivência.

A ironia do destino não tardará a se revelar: um pouco depois de sufocar o amigo, Damon é despertado pelo barulho de carros - ele havia adormecido ali mesmo, ao lado do corpo do companheiro - e descobre que está muito perto da estrada. Ironia trágica (assim que a solução drástica é tomada, o destino mostra que havia uma saída indolor logo ali, à espera de ser percebida) ou crueldade das leis naturais (se tivesse de carregar o amigo, nenhum dos dois teria sobrevivido).

"Mas por que dramatizar um filme que até então havia recusado toda dramatização?", indaga Delorme. E seria preciso aqui fazer outra pergunta: o que é a dramatização, o que a define enquanto tal? Lourcelles, em seu livro sobre Preminger, responde: "a dramatização nada mais é que fazer ver e contar, sem perder tempo" ${ }^{220}$. Ela busca exprimir um assunto por uma decupagem e uma análise de sua evolução em momentos-chave, em episódios representativos, cenas escolhidas por seu poder de revelação. "Como um bom inquiridor, a dramatização busca o lugar e a hora. Ela tem por tarefa estar lá no bom momento. Quando ela chega, em geral não há mais nenhum conflito entre o superficial e o profundo, mas um acordo durável selado entre eles, uma revelação tácita e intensa de um pelo outro. Seu papel consiste também em assinalar o que une e o que divide os personagens: ela mede a distância que os separa" (Lourcelles). A dramatização se ocupa preferencialmente dos afrontamentos, suas causas e suas conseqüências.

Ora, nada disso rima com o projeto abstrato de Gerry. O filme não está preocupado com uma seleção rigorosa dos episódios e dos lugares, com o exame das causas e das conseqüências, com a exposição conflitual de um assunto, com a conversão de sentimentos interiores em ações musculares. Muito pelo contrário. Tudo que interessa ao filme é a

\footnotetext{
219 Idem, p. 44.

220 Otto Preminger, Paris: Éditions Seghers, 1965.
} 
travessia de um mistério, como quem avança num corredor tateando no escuro.

Há um filme de Joseph Losey que podemos situar ao mesmo tempo ao lado e ao largo de Gerry: é Figures in a Landscape, de 1970, que encena uma fuga sem motivo esclarecido, num exuberante cenário montanhoso de um país não especificado. $\mathrm{O}$ enredo beira o absurdo kafkiano: dois homens fogem (do quê?), um helicóptero os persegue (por quê?), depois todo um exército anônimo se junta à caçada. A paisagem é de uma opacidade grandiosa, intransponível. Trata-se de uma reflexão filosófica travestida em filme de perseguição ou vice-versa; epopéia mental que se materializa numa aventura a céu aberto, totalmente física, pois ainda que uma alegoria política perpasse o filme, os dois fugitivos não são símbolos, mas homens de carne, osso, sangue e suor. O personagem de Malcolm McDowell é mais frágil, sensível, cultivado. O de Robert Shaw é mais bronco, violento, selvagem. A oposição que eles representam é bem conhecida. A princípio antagonistas, eles pouco a pouco aprendem a se respeitar, tornando-se solidários nessa situação em que se acham enredados no "combate primitivo de criaturas isoladas para sobreviver a uma opressão organizada"221.

Embora trufado de tempos mortos, Figures in a Landscape é um filme de ação, algo que definitivamente não se pode dizer de Gerry. A diferença fundamental entre os dois filmes se expressa com clareza nos diálogos. Em Figures in a Landscape, quando há uma pausa na fuga, os personagens falam do passado, contam histórias pessoais, expõem sua vida íntima (Robert Shaw contando como conseguiu transar com sua mulher em pleno coreto de uma praça pública, por exemplo). Em Gerry, quando cai a noite e os personagens se esquentam ao redor da fogueira, eles travam diálogos ininteligíveis, ou inventam pequenas ficções, evocam lendas, narram fábulas fabricadas na hora ("Eu conquistei Tebas, governei essa terra por 97 anos...", Casey Affleck conta à beira da fogueira); nenhum passado ilumina o caminho, eles só enxergam o presente, o presente em estado bruto. O único passado permitido é o mito.

Os dois filmes sugerem a abstração já no título: "Gerry" é uma expressão que não existe no dicionário e que pode ser usada como nome, adjetivo, substantivo e o que mais der, ou seja, pode significar tudo e nada ao mesmo tempo; já "Figures in a Landscape" poderia ser o título de um filme experimental em que absolutamente nada se discerne em termos de trama e narração. Mas no caso do filme de Losey, o título antecipa também uma simplicidade, uma retidão da narrativa. A despeito de toda imprecisão geopolítica da trama e de toda arbitrariedade da situação, a perseguição acarreta questões pragmáticas e objetivas. Os personagens vêem a ameaça e podem combatê-la, tanto que matam um dos ocupantes do helicóptero com um tiro. E eles possuem um trajeto definido, caminham rumo a uma fronteira

${ }^{221}$ Cf. Robert Benayoun, “Échos sur une participation”, em Positif no 124, fevereiro de 1971, p. 69. 
que precisam transpor. Uma fronteira, no fundo, é um elemento abstrato, porém mais tangível que a tal "coisa" que os dois gerrys tinham ido ver no deserto e da qual, de todo modo, eles desistem logo que chegam. Ultrapassar a fronteira, em Figures in a Landscape, supostamente garantirá aos personagens a liberdade. Em Gerry, diferentemente, nada aprisiona os personagens a não ser a própria amplidão do espaço. Não há o que combater. Van Sant aborda um mundo cuja grande ameaça é não ter fronteiras nem quem afrontar (o mundo virtual?). A luta dos personagens, então, será de uma nova modalidade: não mais contra os outros homens e contra a morte, mas tão-somente contra a desaparição. Nesse deserto que de certo modo é a amplificação tão palpável quanto fantasmática dos novos espaços virtuais que se oferecem aos jovens, os corpos têm um lugar cada vez menos evidente, e talvez por isso Gus Van Sant evite propositalmente dramatizá-los.

Matt Damon e Casey Affleck, em Gerry, desmontam a representação no sentido clássico de uma interioridade que se exterioriza através de ações e falas. Eles não interpretam, na medida em que não praticam o jogo do ator, "que é precisamente o incessante vai-e-vem entre realidade das pessoas e irrealidade da ficção"222. No deserto de Gerry, uma clivagem se impõe entre as duas instâncias. Essa ruptura entre o corpo dos atores e a existência dos personagens desfaz "o pacto de encarnação sobre o qual se funda tradicionalmente a mise en scène de cinema" 223 , aquela mise en scène que Alexandre Astruc definiu como um "meio de prolongar os elãs da alma nos movimentos do corpo" 224 . O personagem clássico, "vetor de verdade psicológica ou social, meio de exploração do real" 225 , é trocado por zonas mais confusas do ser, campos de ações ou de presença no mundo que exploram a parte mais visível da performance do ator: o dispêndio de energia, as emissões afetivas. Não se exige do ator a credibilidade de sua representação, mas a disposição de "traçar os limites do que um corpo é capaz" (Bouquet). O personagem não é mais suporte do drama, mas massa prenha de energia submetida unicamente às leis da afetividade e do impulso momentâneo, corpo encerrado no presente, respondendo a estímulos pontuais, habitando uma ficção de estranhamento calcada em mistérios e interrogações sem resposta. O deserto de Gerry é uma grande superfície amorfa que dessignifica o mundo pela planaridade e pelo silêncio, convidando o espectador a um estado de abandono em que a realidade não é decifrada, apenas percebida. "Porquanto não há (ou quase) narração, o tempo se converte em puro assunto de percepção"226. A narrativa é uma sucessão de situações informes, esparramadas sobre o tempo presente: esperas,

\footnotetext{
222 Jean-Michel Frodon, “A l'horizon des films déserts”, Cahiers du Cinéma no 589, abril de 2004, p.19.

223 Idem.

224 Astruc, “Qu'est-ce que la mise en scène?”, Cahiers du Cinéma n 100, outubro de 1959.

225 Bouquet, "De manera que todo comunica".

226 Bouquet, "De manera que todo comunica", p. 161.
} 
deambulações, cansaços, desolações, momentos de tempo perdido, de vazio interminável. "O espaço da ficção é portanto sem centro, sem polaridade, sem direção, assim como o espaço físico do filme"227. "Cada personagem não é senão um estado ou um momento do afeto" ${ }^{228}$. As "leis da afecção" não exigem que cada gesto seja a encarnação precisa de um comportamento legível na atitude corporal. O estar-no-mundo, no regime afetivo do corpo, adquire um sentido mais enigmático, mais sutil. Falta, ao corpo-afecção, a cicatriz interior do drama. Ele se guia ou se perde - pelo mundo através unicamente da bússola de seu afeto. O único “objetivo", o único "drama" dos personagens é continuar sendo corpos, ou seja, não se tornar manchas de tinta numa tela abstrata.

Gerry é o filme pós-maneirista por excelência, a conseqüência natural do remake colorido de Psicose (1998), que já havia sido um primeiro "filme de galeria" de Gus Van Sant (algo como: Hitchcock encontra Andy Warhol), ao mesmo tempo em que representara um ponto limítrofe do maneirismo e de sua relação obsessiva com obras do passado, reelaboração maníaca - trata-se de um remake plano-a-plano! - da imagem original pelo próprio imaginário que lhe sucedeu (Van Sant escancarava aquilo que sempre esteve implícito no filme mais icônico de Hitchcock: suas imagens desde a origem já se apresentavam como déjà-vu). Cada plano do remake de Psicose é uma aventura plástica e um desafio conceitual. O filme já reúne em si o "fim" do maneirismo e a base do cinema-dispositivo que virá substituí-lo na obra de Gus Van Sant.

Enquanto definíamos o maneirismo cinematográfico, vimos que um de seus aspectos cruciais era uma dificuldade de articulação, levando o cineasta a suprir tal dificuldade escolhendo, grosso modo, entre o retraimento ou a vertigem formal. Eis que Gerry simplesmente não se impõe mais a questão da articulação, configurando o deserto como o lugar em que todas as porções do espaço são naturalmente contíguas, e todas as hipóteses de ficção se comunicam como que por um passe de mágica, à mesma medida que se esvaziam mutuamente. Entram em ação "os deslizamentos de mundo do universo virtual, onde as figuras passam de um cenário a outro sem dificuldade" 229.

O remake de Psicose abrira um caminho para Gus Van Sant: uma vez que os espectadores já conhecem essa trama difundida e repetida à exaustão, já sabem de antemão o desfecho, o cineasta pode se dedicar à cor, à luz, às nuances de atuação, à fermentação ou sutilização dos elementos plásticos bem como das mensagens implícitas no enredo. Liberado da tarefa de narrar, ele se concentra então nas maneiras. Não é só um remake de roteiro, mas

${ }^{227}$ Stéphane Bouquet, "Un art qui transporte", Cahiers du Cinéma no 512, pp. 24-25.

${ }^{228}$ Delorme, "Les lois de l'affection", Cahiers du Cinéma, fevereiro de 2006, p. 78.

${ }^{229}$ Delorme, "Compagnie", p. 43. 
sobretudo de mise en scène $e^{230}$. Van Sant, no entanto, não emula o "touch" hitchcockiano. Sua tarefa consiste em criar uma cenografia, uma ambiência que irá acolher histórias e personagens egressos de um outro filme. A narração, a decupagem e a dramatização são assuntos anteriores, quiçá exteriores, que não lhe cabe alterar: sua matéria são os cenários, as cores das roupas, os corpos dos atores, a maneira como eles repetem ou modificam os gestos do filme original. Van Sant não trabalha aqui o sentido, mas o signo.

Da mesma forma que o espectador de Psicose entra no cinema, em 1998, sabendo que com menos de uma hora de filme a mocinha vai morrer (não creio que Van Sant tenha feito esse remake para atingir um público que não havia visto o original - seu filme conta com a presciência do espectador), ele saberá também, em 2003 e 2005, respectivamente, que aqueles alunos que caminham pelos corredores da escola já foram assassinados (Elefante) e que Kurt Cobain já morreu (Last Days). O espectador se deixará então envolver pela bruma de sensações que recobre esses eventos. "Nesses filmes, o drama está lá, ele plana, ele ocorrerá, ele já ocorreu, marchemos com ele. Não há o que fazer além de lá se situar, sem grito nem crise de histeria. As pequenas melodias no piano (Beethoven, Arvo Pärt) são ressurgências muito distantes de uma humanidade anterior ao desastre que vêm ninar nossa consciência da perda"231. O drama não é a decorrência da duração, pois a duração é que é a decorrência do drama: este já aconteceu, antes mesmo de o filme começar, e o que resta agora é atravessar o espaço em que ele se deu, guiado por uma consciência pós-catástrofe que se limita a contar o tempo da travessia.

Em Psicose, a questão era: como narrar uma história de suspense uma vez que ela já foi filmada à perfeição irretocável, como refilmar um clássico supremo senão repetindo os mesmos planos? Em Elefante, a questão será: como reconstituir um evento traumático (o massacre de Columbine) senão assumindo que ele é inexplicável e inesgotável em sua causalidade tão múltipla quanto desconhecida, e que tentar explicar o evento parece menos urgente e viável do que acompanhar as conseqüências de deslocamento nas novas relações de espaço e tempo a ele associadas? Nos dois casos, o que está em jogo é uma espécie de impossibilidade da mise en scène. A solução para isso é encontrada na dimensão conceitual dos projetos: o remake de Psicose se coloca não só como a reencenação de um espetáculo, mas sobretudo como a exposição de uma idéia sofisticada sobre a natureza da imagem, sobre o funcionamento da indústria hollywoodiana, sobre a mística do déjà-vu hitchcockiano etc;

\footnotetext{
230 "Esse filme tem também uma relação com o teatro: Gus Van Sant filma Hitchcock como os encenadores contemporâneos montam Shakespeare, salvo que o texto, aqui, é não apenas o diálogo, mas também a decupagem." (cf. "My own private Psycho", em Cahiers du Cinéma no 532, p. 48)

231 Delorme, "Compagnie", p. 43.
} 
Van Sant não desiste aí da mise en scène, mas a torna subsidiária de um conceito. Em Elefante, ela será tragada pelas operações de um dispositivo que converte lugares e ações em puros deslizamentos de espaço-tempo: montado o dispositivo e assegurada a correspondência plástico-conceitual da obra, o espaço e a ação se constroem na sua continuidade mesma, por topologia e por passagem de forças, numa dinâmica de fluidos que carreia indistintamente as partículas "boas" e as "ruins" para seus respectivos destinos. A violência se imiscui nessa dinâmica, se automatiza em sua face neutra, é imanente à estrutura. A montagem desregula o sistema causa-conseqüência de modo a garantir que nenhuma das ações violentas se articule efetivamente a um motivo. A dramatização não tem mais lugar.

Comumente visto como um recomeço ou um ponto de ruptura na carreira de Gus Van Sant, Gerry deve ser encarado, na verdade, como o traço de união, a faixa de terra que se estende entre a reciclagem maneirista da mise en scène (Psicose) e sua acoplagem num dispositivo (Elefante). Após refilmar Psicose plano a plano, Van Sant percebeu que o sentido estava dado e esgotado - restava o deserto dos signos a percorrer e explorar. "Existe somente esse filme que terá sintetizado a saída de rota da pós-modernidade, ou digamos do maneirismo, e sua transformação, seu rebaixamento, em uma cultura pop instantânea? Se os anos zero propuseram o ponto de cruzamento entre uma forma conceitualizada, serializada, e a juventude como modelo e como alvo, então sim, Gerry foi sua ascensão, sua milestone"232.

$\overline{{ }^{232} \text { Philippe Azoury, Cahiers }}$ du Cinéma no 652, janeiro de 2010, pp. $20-21$. 


\section{Considerações finais}

O horizonte futuro de nossos questionamentos, como bem se pode depreender do conteúdo desta dissertação, é obrigatoriamente incerto. Abordamos um cinema ainda em andamento, em transformação. O que as obras de Hou Hsiao-hsien, Claire Denis, Gus Van Sant ou Philippe Grandrieux ainda terão para acrescentar ao tema nos próximos anos? Muita coisa, sem dúvida. É natural que agora existam mais interrogações que conclusões. Para onde aponta esse percurso que acabamos de fazer? O que estabelecer como limite para o conceito de mise en scène e, por conseguinte, como parâmetro para relativizar a questão de sua ausência ou seu "fim" no panorama atual?

A partir dos textos analisados na parte I, chegamos a uma definição da mise en scène como ferramenta de reflexão sobre o mundo associada à idéia de fascinação, mas também de afrontamento. A mise en scène implicaria uma ação de deslocamento do sujeito, de interpelação do outro, de conflito entre materiais heterogêneos, de transporte do olhar que carrega consigo o corpo, este eixo por onde se articula a primeira questão de ordem política no cinema: a partilha sensível do espaço. Um cinema sem mise en scène seria, no limite, um cinema que se nega ao afrontamento, se nega a interpelar o outro, seja para buscar um acordo ou um conflito. A mise en scène, assim, se trocaria pela rarefação do cinema - e mais especificamente do núcleo duro de sua linguagem, o plano - numa estética de livre circulação de imagens. Enquanto o plano atrelado à dramaturgia e à mise en scène incita a relação com os outros planos, a imagem que flutua numa atmosfera sem gravidade se comporta como um elétron solto. Ao permitir o livre fluxo de imagens, o cineasta deixaria de ser um metteur en scène e se tornaria um agenciador de signos e potências. Da fascinação, palavra que resume a relação espectador-filme nos textos de Mourlet e em "Génie de Howard Hawks" de Rivette, passa-se à sideração (palavra recorrente no vocabulário crítico dos anos 2000). A fascinação supõe um espectador tencionado rumo à tela, reagindo emocionalmente ao conteúdo do filme; a sideração supõe um espectador atonizado em meio às imagens, hipnotizado, inundado por sensações etéreas.

O Intruso (Claire Denis), Café Lumière (Hou Hsiao-hsien), Sombra (Philippe Grandrieux) e Gerry (Gus Van Sant), para citar alguns dos filmes que analisamos, flertam com esse limite a partir do qual a ausência de mise en scène, ou a ausência de uma certa idéia de mise en scène (aquela visitada na parte I), desaguaria no puro ato de contemplação sem afrontamento e, como disse Stéphane Bouquet em sua crítica à estética de fluxo, na negação 
da alteridade e da heterogeneidade. "É um mundo sem diferença, sem alteridade. É preciso mergulhar no movimento comum, ceder o pensamento pela sensação”, Bouquet afirmou. Só que esses filmes ainda não eram a conflagração daquela ameaça que ele enxergava nessa tendência ao isolamento sensorial. Pode até não haver neles a mise en scène no sentido clássico, ou tal como ela foi teorizada nos textos de Mourlet, Rohmer, Rivette, Astruc, Lourcelles etc. Mas é evidente que nenhum daqueles filmes, de Sombra a O Intruso, de Gerry a Café Lumière, de Blissfully Yours a Nénette et Boni, cai numa zona de indiferença estética; eles ainda aceitam o desafio de concretizar uma relação com o Outro e com o Mundo.

O que significa, então, falar de um cinema sem outro, sem fora? Que tipo de filme permitiria tal constatação?

Há um filme recente que podemos citar como exemplo: Viajo Porque Preciso, Volto Porque Te Amo, de Karim Aïnouz e Marcelo Gomes. A narrativa se desenvolve assim: um geólogo atravessa o sertão nordestino fazendo uma pesquisa de campo para a futura construção de um canal que desviará as águas de um rio e inundará alguns vilarejos. No caminho, ele lembra da ex-mulher e, por meio de uma onipresente narração em off, fala da melancolia provocada por sua falta. O filme vai somando no vazio signos e rostos que colhe ao longo do trajeto. Alguns encontros (com jovens mulheres, com trabalhadores, com moradores das regiões pesquisadas) pontuam a viagem, mas sem render uma mudança efetiva de rota ou de humor. Resultado: setenta minutos de um mesmo sentimento - uma baita dor de cotovelo - sendo reiterado num travelogue solitário, diário íntimo de viagem à beira do autismo. O espaço não ajuda: tudo parece igual, sempre o mesmo, como se não houvesse movimento e mudança; a solidão dos lugares os desdiferencia. Uma inércia se instala: as imagens de Karim Aïnouz e Marcelo Gomes nem operam um deslocamento imaginário do espectador, como na ficção psicológica clássica, nem o afetam fisicamente, como nas obras dos cineastas-artistas que dão ênfase à expressão imediata de sensações (Claire Denis e Philippe Grandrieux seriam exemplos desses cineastas). As imagens passam por nós de modo inofensivo; colocadas todas em primeira pessoa, elas são depósitos de impressões subjetivas. Não vemos o corpo do protagonista (ele é uma voz e um olhar - em raros momentos, é também um ouvido); só vemos o interior de suas reações ao mundo. O corpo do "herói”, que no sistema estético de Michel Mourlet era o eixo central através do qual se organizava a cena, e por onde passava toda a energia física gasta durante a filmagem, está ausente desse filme.

Aïnouz e Gomes instauram um lugar onde tudo começa e termina no "eu lírico" do narrador, em sua coleção de objetos afetivos. Ele se isola em sua sensibilidade individual, nas doces afecções de um olhar ensimesmado. O mundo exterior é vivido como sensação distante, 
como impressão fugidia.

Viajo Porque Preciso, Volto Porque Te Amo remete a um punhado de anti-road movies em que a paisagem é existencial e a errância é tencionada/motivada por algo ou alguém que não está nas imagens. O mais forte dos exemplos recentes é The Brown Bunny (2003): a viagem de Vincent Gallo pelas estradas dos Estados Unidos é também um desfile de paisagens interiores, paisagens-afecção, uma jornada que se espraia sobre o deserto criado pela ausência de uma mulher. A diferença é que Gallo vai fundo nos desdobramentos de seu movimento cíclico de estagnação no presente ${ }^{233}$. Ele desliza sobre a superfície morta de uma paisagem mineral e desértica (vales rochosos, planícies secas); flerta e seduz várias mulheres que encontra pelo caminho, mas sempre corta o contato que havia começado, não se permitindo uma relação carnal com nenhuma delas. Na ausência de Eros, um instinto de morte prevalece sobre o personagem e o impele a se confundir à matéria inanimada das paisagens que percorre ${ }^{234}$. A mais perfeita tradução disso se dá naquela famosa cena em que ele pilota sua moto num deserto de solo branco, salino, se distanciando da câmera até se desmanchar no horizonte, virar miragem, dissolver-se na poeira inorgânica. Por um lado, está desconectado de tudo, da sociedade, das pessoas. Por outro, está intensa e imediatamente requisitado por experiências concretas (dentre as quais a moto-velocidade). Sua desconexão do mundo é de uma natureza tal que o põe em relação muito próxima e muito essencial com alguma outra coisa - com o fantasma da mulher amada, com a sensação de velocidade, com a pulsão de morte. Mais tarde, Gallo faz aflorar no filme a cesura ficcional que o gerou: o evento traumático de uma morte que é reencenada duplamente, como flash-back (a noite em que tudo ocorreu é mostrada em fragmentos inconclusos) e como encontro (ele enfim trava uma relação sexual, mas com um fantasma), ambos perturbadores. Há, portanto, uma tensão, um drama, uma catarse, uma agitação de forças, um inchamento do universo e seu posterior retraimento - um motivo para vermos o filme além do puro gozo ou desconforto de sensações.

Olivier Joyard identifica em The Brown Bunny "o nascimento de uma forma refratária a todo hábito do olhar", que ele qualifica de "plano-conceito sentimental"235. O filme conciliaria a radicalidade estética ao afeto por meio dessa nova modalidade de plano que é a um só tempo conceito e sentimento. O crítico destaca ainda o look publicitário de algumas

${ }^{233}$ The Brown Bunny termina com um fotograma congelado, reforçando o estado de fixação de seu personagem. Two Lane Blacktop (1971), de Monte Hellman, marco crucial na história do road-movie norte-americano e principal ancestral de The Brown Bunny, termina com um fotograma queimando na tela. Seria interessante comparar os dois filmes à luz dessa mudança expressa substancialmente na forma como um e outro terminam. Da combustão ao congelamento, toda uma história do cinema americano moderno pode ser contada.

${ }^{234}$ Algo que também pudemos observar em Gerry.

235 “Ce quoi ce plan (la suite)?”, em Cahiers du Cinéma n 580. 
composições, que reforçam a solidão absoluta do personagem pela evocação paradoxal de um imaginário que insere o indivíduo num espaço abstrato onde ele é o $\mathrm{Eu}$ todo-poderoso. Ressignificados pelo filme, os "enquadramentos demasiadamente arty para serem verdadeiros, as cores brancas demais" típicas da publicidade nada mais são que imagens egressas do fundo da morte. "[Gallo] opta por uma estratégia violenta de isolamento e coagulação. O espectador entra (ou recusa entrar) num mundo em que ele não é bem-vindo, deixado à porta de um estado de espírito que ele jamais compreenderá verdadeiramente" ${ }^{\text {"236 }}$.

Outro filme que vem à mente, menos como semelhança do que como antítese de Viajo Porque Preciso, é Le Camion (1977), no qual Marguerite Duras já via despontar no horizonte um mundo - e portanto um cinema - sem Outro, sem fora, sem embate entre posições antagônicas. Não o seu cinema, que fuxicaria o Outro mesmo lá onde ele insistisse em se esconder, mas um cinema que viria depois, vinte anos depois, trinta anos depois - um cinema cuja matéria não é o mundo, mas uma certa sensibilidade em relação ao mundo, a saber a sensibilidade dos diretores-autores.

Le Camion reduzia o cinema a um teatro de câmara intramental (fazendo eco a outras ficções claustrofóbicas dos anos setenta, outras estéticas de fechamento do quadro e do cenário - Akerman, Syberberg, Godard), transformava-o em espaço de ressonância do pensamento - do pensamento dialético. Duras e Gérard Depardieu apareciam num cômodo escuro que se tornava lugar de projeção, como uma pequena sala de cinema em que, ao invés de uma tela, tivéssemos um corpo se oferecendo como suporte para a imagem. Depardieu recebe a história que Duras projeta. As únicas imagens exteriores ao cômodo escuro são grandes planos gerais que mostram o caminhão cruzando a estrada e, principalmente, planos feitos de dentro do caminhão em movimento que registram melancólicas paisagens de beira de estrada, terrenos vagos de uma região da periferia de Paris, lugares abandonados ao inverno. Na voz de Duras, um discurso se constrói segundo uma constatação bastante precisa: do "toda revolução é possível", ela passa ao "não se diz mais nada, não se vê mais nada, nada: revolução, luta de classes, ditadura do proletariado, nada". Le Camion é o relato de quem assiste ao luto do pensamento marxista. Mas Duras não se conforma e viaja ao fundo da consciência, pois é lá que as diferenças, as rupturas, os conflitos do ego com o mundo exterior persistem, provam-se inapagáveis, mesmo - e sobretudo - aqueles que a vida social habilmente reprime (Daney: "lá onde algo resiste, é preciso filmar").

Se Le Camion era um filme sobre a "perda política"237, Viajo Porque Preciso é o

236 Idem.

237 "Para muita gente a verdadeira perda do sentido político consiste em se juntar a uma formação partidária, submeter-se a sua regra, sua lei. Para muita gente também quando se fala de apolitismo, fala-se antes de tudo 
resultado do agravamento dessa perda nas duas últimas décadas, um exemplo entre mil dos muitos filmes (e vídeos, e performances, e instalações...) que hoje mobilizam um conjunto de imagens com muito verniz artístico, mas pouca relação concreta com coisas realmente interessantes.

O crepúsculo do pensamento dialético abriu caminho para a voga do olhar neoimpressionista não-significante, e esta abriu caminho para um cinema "inerte". Inerte por dois motivos: primeiro, pela frouxidão da técnica (in-ars $=$ sem arte, sem poder de realização); segundo, pelo estímulo a uma passividade do olhar que o paralisa em estados précognitivos e pré-conscientes. Em outras palavras, um cinema muito aquém das reais possibilidades de seu dispositivo.

Embora o conceito de "cinema de fluxo" (ou "estética de fluxo") tenha permanecido um pivô das discussões aqui empreendidas, sendo apresentado já no título da dissertação, procuramos evitar um emprego abusivo do conceito, não forjando a partir dele uma unidade estilística que negligenciaria algumas particularidades de cineastas e filmes e, mais ainda, algumas diferenças fundamentais que existem entre eles. Além disso, ficou constatado que nem sempre se pode opor mise en scène e fluxo, ou que ao menos se deve ter um enorme cuidado nessa oposição. Basta citar o caso de Hou Hsiao-hsien, que, apesar de se encaixar perfeitamente no cinema de fluxo, apresenta também uma estratégia de composição de cenas e planos diante da qual seria tolo evitar a expressão mise en scène somente para manter a pretensa integridade de um conceito. Se, na análise de A Viagem do Balão Vermelho, só empregamos a expressão mise en scène uma única vez, ao final, entre parênteses e sucedida de uma interrogação, não foi por nenhum tipo de pudor, mas porque a dúvida sobre o que caracterizava o limite a partir do qual já não se teria mais mise en scène, porém outra coisa, carecia - e ainda carece - de uma resposta fácil, conclusiva.

O trabalho, aliás, é um roteiro fiel das perguntas e das eventuais respostas que surgiram. Ele restitui - quase linearmente - o percurso que o projeto foi tomando ao longo desses trinta meses. Os recuos que se provaram necessários, os desvios, os atalhos, as

de uma perda ou de uma ausência ideológica. Eu não sei o que vocês pensam quanto a isso. Para mim a perda política é antes de tudo a perda de si, a perda de sua cólera assim como a de sua doçura, a perda de seu ódio, de sua faculdade de odiar assim como a de sua faculdade de amar, a perda de sua imprudência assim como a de sua moderação, a perda de um excesso assim como a perda de uma medida, a perda da loucura, de sua ingenuidade, a perda de sua coragem como a de sua covardia, a de seu terror diante de tudo assim como a de sua confiança, a perda de suas lágrimas assim como a de seu prazer. É isso o que eu penso." (Marguerite Duras, "La perte politique", Cahiers du Cinéma nº 312-313, junho de 1980). 
dúvidas, as hipóteses, as elipses, as saídas e chegadas vão aparecendo de maneira mais ou menos cronológica, mantendo, em grande medida, a ordem em que se apresentaram. Questões que a princípio receberiam uma investigação mais detalhada foram mencionadas en passant (o flerte do cinema com as artes de instalação e ambiência contemporâneas); outras que atuariam como coadjuvantes ganharam a dianteira (a recorrente indagação sobre a dissolução do drama nos filmes analisados). Obras que num primeiro momento fariam parte da filmografia principal (Mal dos Trópicos e Objeto Misterioso ao Meio-dia de Apichatpong Weerasethakul, por exemplo) acabaram sendo naturalmente substituídas por outras que não desfrutavam nenhuma prioridade no embrião do projeto (Sombra, de Philippe Grandrieux).

É possível que tanto a parte I da dissertação, por sua parcela de "resenha histórica", quanto a parte II, pela ponte que estende do "momento maneirista" dos anos 1980 ao cinema da última década, tenham incomodado quem prefere pensar o cinema e sua teoria não como uma história, uma sucessão de estilos, sistemas e escolas estéticas, e sim como um "plano de imanência", um devir infinito, um conjunto móvel de idéias, forças, potências, mitos, propriedades etc. Mas chamo a atenção para o fato de que o trabalho coloca em contato, a todo momento, filmes e conceitos de épocas distintas, estimulando um diálogo que não se encerra na compreensão linear de uma "história recente do cinema".

Ademais, parece-me sim importante - sobretudo em se tratando de um cinema que muitos tendem a ver como "inédito" e "novo" em todas as suas operações - enxergar de onde vêm as coisas, o que elas continuam, o que abandonam, o que os cineastas herdam por osmose, o que negam por instinto. "A arte, entre outras coisas, é continuidade, sendo impensável sem ela" (Clement Greenberg). 


\section{Bibliografia}

ASTRUC, Alexandre, “Qu'est-ce que la mise en scène?”, Cahiers du Cinéma $\mathrm{n}^{\circ}$ 100, outubro de 1959.

AUMONT, Jacques, Le cinéma et la mise en scène, Paris: Armand Colin, 2006. . O cinema e a encenação, Lisboa: Edições Texto \& Grafia, 2008.

(org.), La mise en scène, Bruxelas: Éditions De Boeck Université, 2000. . O Olho Interminável, São Paulo: Cosac \& Naify, 2004. . Moderne?, Paris: Ed. Cahiers du Cinéma, 2007. . À quoi pensent les films, Paris: Nouvelles Éditions Séguier, 1996.

BAECQUE, Antoine de (org.), Teoría y crítica del cine, Buenos Aires: Paidós, 2005. . La política de los autores, Buenos Aires: Paidós, 2005.

BAZIN, André, Qu'est-ce que le cinéma?: I. Ontologie et Langage, Paris: Les Éditions du Cerf, 1958.

BERGALA, Alain, "Sur un art ignoré, côté face", in AUMONT, Jacques (dir.), Le Septième Art, Paris: Éditions Léo Scheer, 2003. . “D'une certaine manière”, Cahiers du Cinéma no 370, abril de 1985.

BONITZER, Pascal, Le champ aveugle: essais sur le réalisme au cinema, Paris: Éditions Cahiers du Cinéma, 1999. Décadrages, Paris: Éditions Cahiers du Cinéma, 1987.

BORDWELL, David e THOMPSON, Kristin, Film Art: An Introduction / Second edition, Nova Iorque: Alfred A. Knopf, 1986.

BORDWELL, David, Figures traced in light, Los Angeles: University of California Press, 2005.

BOUQUET, Stéphane, “Claire Denis, les années sauvages de Nénette et Boni”, Cahiers du Cinéma $\mathrm{n}^{\circ} 501$. . "Plan contre flux", Cahiers du Cinéma no 566.

. "Des films et des gestes", Cahiers du Cinéma n n 578.

. "De manera que todo comunica", in BAECQUE, Antoine de (org.), 
Teoría y crítica de cine, Buenos Aires: Paidós, 2005.

DANEY, Serge, A Rampa, São Paulo: Cosac \& Naify, 2007. . Persévérance, Paris: POL, 1994

DELEUZE, Gilles, L'Image-Mouvement, Paris: Les Éditions de Minuit, 1983.

DELORME, Stéphane, “Les lois de l'affection”, Cahiers du Cinéma, fevereiro de 2006. . “Un défaut d'articulation", Cahiers du Cinéma nº 602, junho de 2005. . “Compagnie", Cahiers du Cinéma nº 588, março de 2004.

ELSAESSER, Thomas, Early Cinema: Space, Frame, Narrative, Londres: British Film Institute, 1990.

FREUD, Sigmund, Obras Psicológicas de Sigmund Freud - Volume 2: Escritos sobre a Psicologia do Inconsciente, Rio de Janeiro: Imago, 2006.

FRODON, Jean-Michel, Horizon cinéma, Paris: Éditions Cahiers du Cinéma, 2006.

2004. . "À l'horizon des films déserts”, Cahiers du Cinéma n 589, abril de (org.), Hou Hsiao-hsien, Paris: Éditions Cahiers du Cinéma, 1999.

GAUDREAULT, André, Cinéma et attraction, Paris: CNRS Éditions, 2008.

GOETHE, Johann Wolfgang, Escritos sobre a arte, São Paulo: Humanitas/Imprensa Oficial, 2008.

GREENBERG, Clement, Clement Greenberg e o debate crítico, Rio de Janeiro: Jorge Zahar, 2001.

GUINSBURG, J., O Classicismo, São Paulo: Perspectiva, 1999.

HEGEL, L'art classique, Paris: Aubier-Montaigne, 1964.

HOCKE, Gustav, Maneirismo: o mundo como labirinto, São Paulo: Perspectiva/Edusp, 1974. HOVEYDA, Fereydoun, “Les Taches du soleil”, Cahiers du Cinéma n 110, agosto de 1960. JOYARD, Olivier, “C'est quoi ce plan (la suite)?”, Cahiers du Cinéma n 580.

LALANNE, Jean-Marc, “C’est quoi ce plan?”, Cahiers du Cinéma nº 569.

LICHTENSTEIN, Jacqueline, A pintura - Vol. 9: O desenho e a cor, São Paulo: Ed. 34, 2006. LOURCELLES, Jacques, “Journal de 1966”, Présence du Cinéma n 24-25, outono de 1967. 
. Otto Preminger, Paris: Éditions Seghers, 1965.

MERLEAU-PONTY, Maurice, "O cinema e a nova psicologia”, in XAVIER, Ismail (org.), $A$ Experiência do Cinema, Rio de Janeiro: Graal/Embrafilme, 1983.

. A Natureza, $2^{\mathrm{a}}$ ed., São Paulo: Martins Fontes, 2006.

MOURLET, Michel, “Sur un art ignoré”, Cahiers du Cinéma nº 98, agosto de 1959.

1959. . “Trajectoire de Fritz Lang”, Cahiers du Cinéma no 99, setembro de . "Billet Londonien", Cahiers du Cinéma nº 102, dezembro de 1959.

Poche Cinéma, 2008.

Sur un art ignoré ou la mise en scène comme langage, Paris: Ramsay,

RANCIÈRE, Jacques, A partilha do sensível. São Paulo: Editora 34, 2005.

. La fable cinématographique, Paris: Seuil, 2001

REYNAUD, Bérénice, Nouvelles Chines, nouveaux cinémas, Paris: Éditions Cahiers du Cinéma, 1999.

RIVETTE, Jacques, “Génie de Howard Hawks”, Cahiers du Cinéma no 23, maio de 1953.

. "Lettre sur Rossellini”, Cahiers du Cinéma n 46, abril de 1955.

. "Notes sur une révolution", Cahiers du Cinéma n ${ }^{\circ}$ 54, dezembro de

1955.

. "L'essentiel”, Cahiers du Cinéma no 32, fevereiro de 1954.

. "En attendant les Godons", Cahiers du Cinéma nº 73, julho de 1957.

. "Sainte Cécile", Cahiers du Cinéma no 82, abril de 1958.

. “Da abjeção", Cahiers du Cinéma no 120, junho de 1961.

ROHMER, Éric, Le goût de la beauté, Paris: Éditions de l'Étoile/Flammarion, 1989.

. "Le celluloid et le marbre - II: Les siècles des peintres", Cahiers $d u$ Cinéma no $^{\circ}$, julho de 1955.

51 , outubro de 1955 .

. "Le celluloid et le marbre - III: De la métaphore", Cahiers du Cinéma n ${ }^{\circ}$

PANOFSKY, Erwin, Significado nas artes visuais, $3^{\mathrm{a}}$ ed., São Paulo: Perspectiva.

, Idea: a evolução do conceito do Belo, $2^{\mathrm{a}}$ ed. São Paulo: Martins Fontes, 
2000.

SADOUL, Georges, Louis Lumière, Paris: Éditions Seghers, 1964.

SERGUINE, Jacques, "Educação do espectador (ou a escola do Mac Mahon)", Cahiers du Cinéma $\mathrm{n}^{\circ} 111$, setembro de 1960.

SCHILLER, Friedrich, Cartas sobre a Educação Estética da Humanidade, São Paulo: Herder, 1963.

STAM, Robert, Introdução à teoria do cinema, Campinas, SP: Papirus, 2003.

VALÉRY, Paul, Introdução ao Método de Leonardo Da Vinci, São Paulo: Ed. 34, 1998.

VILLAIN, Dominique, L'oeil à la caméra: Le cadrage au cinéma, Paris: Cahiers du Cinéma, Editions de l'Etoile, 1985.

WHITEHEAD, Alfred North, O Conceito de Natureza, São Paulo: Martins Fontes, 1993.

WÖLFFLIN, Heinrich, Renascença e Barroco, São Paulo: Perspectiva, 1989.

XAVIER, Ismail (org.), A experiência do cinema, Rio de Janeiro: Graal/Embrafilme, 1983.

XAVIER, Ismail, O olhar e a cena, São Paulo: Cosac \& Naify, 2003.

. O discurso cinematográfico, São Paulo: Paz e Terra, 2005. 


\section{Filmografia principal}

Roberto Rossellini:

Stromboli (Itália/EUA, 1950)

Otto Preminger:

Passos na Noite (Where the Sidewalk Ends, EUA, 1950)

Bunny Lake Desapareceu (Bunny Lake Is Missing, Reino Unido, 1965)

Joseph Losey:

The Criminal (Reino Unido, 1960)

No Limiar da Liberdade (Figures in a Landscape, Reino Unido, 1970)

Alfred Hitchcock:

Os Pássaros (The Birds, EUA, 1963)

Brian De Palma:

Trágica Obsessão (Obsession, EUA, 1976)

Jim Jarmusch:

Permanent Vacation (EUA, 1980)

Lars Von Trier:

O Elemento do Crime (Forbrydelsens element, Dinamarca, 1984)

Claire Denis:

Nénette et Boni (França, 1996)

O Intruso (L'intrus, França, 2004)

Philippe Grandrieux:

Sombra (Sombre, França, 1998)

Gus Van Sant:

Psicose (Psycho, EUA, 1998)

Gerry (EUA, 2002)

Elefante (Elephant, EUA, 2003)

Últimos Dias (Last Days, EUA, 2005)

Apichatpong Weerasethakul:

Blissfully Yours (Sud sanaeha, Tailândia/França, 2002)

Vincent Gallo:

The Brown Bunny (EUA, 2003)

Hou Hsiao-hsien:

Café Lumière (Kôhî jikô, Japão/Taiwan, 2003)

A Viagem do Balão Vermelho (Le Voyage du Ballon Rouge, França/Taiwan, 2007) 
Lucrecia Martel:

A Mulher Sem Cabeça (La mujer sin cabeza, Argentina/França/Itália/Espanha, 2008)

Karim Aïnouz e Marcelo Gomes:

Viajo Porque Preciso, Volto Porque Te Amo (Brasil, 2009) 